UNIVERSIDADE DE SÃO PAULO

FFCLRP - DEPARTAMENTO DE PSICOLOGIA

PROGRAMA DE PÓS-GRADUAÇÃO EM PSICOLOGIA

O corpo (inter)face: sentidos sobre a relação sujeito, corpo e objetos tecnológicos de conexão à rede eletrônica

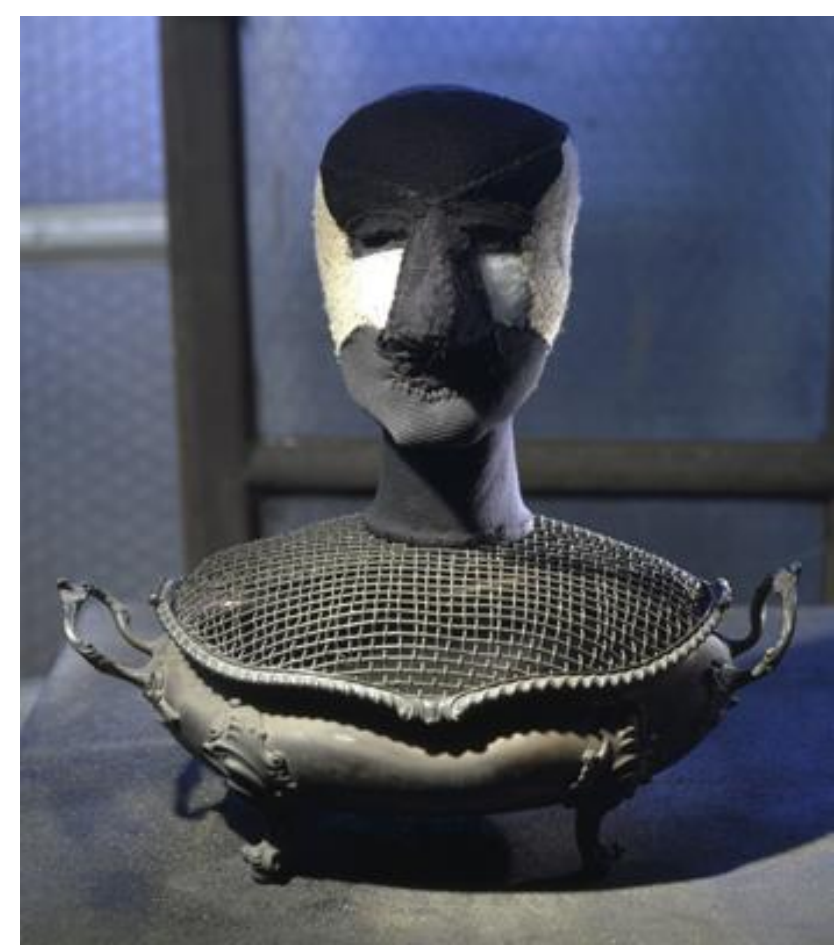

\title{
Daniela Giorgenon
}

Tese apresentada à Faculdade de Filosofia, Ciências e Letras de Ribeirão Preto da USP, como parte das exigências para a obtenção do título de Doutor em Ciências, Área: Psicologia. 
DANIELA GIORGENON

O corpo (inter)face: sentidos sobre a relação sujeito, corpo e objetos tecnológicos de conexão à rede eletrônica

Tese apresentada à Faculdade de Filosofia, Ciências e Letras de Ribeirão Preto da USP, como parte das exigências para a obtenção do título de Mestre em Ciências, Área: Psicologia.

Orientadora: Profa. Dra. Lucília Maria Abrahão e Sousa 
Autorizo a reprodução e divulgação total ou parcial deste trabalho, por qualquer meio convencional ou eletrônico, para fins de estudo e pesquisa, desde que citada a fonte.

Giorgenon, Daniela

O corpo (inter)face: sentidos sobre a relação sujeito, corpo e objetos tecnológicos de conexão à rede eletrônica. Ribeirão Preto, 2016.

p. 228: il.; $30 \mathrm{~cm}$

Tese de Doutorado, apresentada à Faculdade de Filosofia, Ciências e Letras de Ribeirão Preto/USP. Área de concentração: Psicologia Orientadora: Sousa, Lucília Maria Abrahão e.

1. Sujeito. 2. Discurso. 3. Objeto. 4. Corpo 5. Rede eletrônica

\section{Capa}

Cell XVI (Portrait) (2000)

Louise Bourgeois 


\section{FOLHA DE APROVAÇÃO}

Daniela Giorgenon

O corpo (inter)face: sentidos sobre a relação sujeito, corpo e objetos tecnológicos de conexão à rede eletrônica

Tese apresentada à Faculdade de Filosofia, Ciências e Letras de Ribeirão Preto da Universidade de São Paulo, como parte das exigências para a obtenção do título de Mestre em Ciências, Área de Concentração: Psicologia.

Aprovado em:

\section{Banca Examinadora}

Prof. Dr.

Instituição:

Assinatura:

Prof. Dr.

Instituição:

Assinatura:

Prof. Dr.

Instituição:

Assinatura:

Prof. Dr.

Instituição:

Assinatura:

Prof. Dr.

Instituição:

Assinatura: 


\section{Agradecimento especial}

À Lucília Maria Abrahão e Sousa, minha horizontadora, que me inspirou a buscar horizontes, a ocupar espaços pelo mundo afora, espaços já sonhados outrora, que pareciam tão distantes e que passaram a compor os meus passos, os meus vôos, enfim, o meu percurso. Agradeço ainda, e de novo, e sempre, pela transmissão de uma profundidade, de uma intensidade e de uma vivacidade para o olhar e a escuta aos fatos discursivos, mais, aos fatos de vida, aos fatos poéticos.

A você, o meu agradecimento imenso, de coração. 


\section{Mais agradecimentos}

À Monsieur Éric Bidaud, pour l'accueil aimable pendant le stage de doctorat au Laboratoire "Unité Transversale de Recherche Psychogènese et Psychopathologie" (UTRPP), dans 1'Université Paris XIII - Nord. Je vous remercie pour votre écoute de ma recherche, essentielle pour l'écriture qui est présentée dans cette thèse.

À Soraya Maria Romano Pacífico e Lauro José Siqueira Baldini, caros professores que acompanham meu percurso acadêmico, pelos apontamentos precisos feitos no exame de qualificação, que muito contribuíram para que essa pesquisa avançasse, assim como essa pesquisadora.

À Dantielli Assumpção Garcia, Lauro José Siqueira Baldini, Soraya Maria Romano Pacífico e Vanise Gomes de Medeiros, caros professores, que também muito contribuíram para a elaboração dessa tese e que aceitaram gentilmente o convite para a composição da banca avaliadora da minha defesa de doutorado.

Aos amigos do "Laboratório Discursivo: sujeito, rede eletrônica e sentidos em movimento" (E$1 @$ dis - FFCLRP/USP), especialmente à Daiana de Oliveira Faria, Gustavo Grandini Bastos, Rodrigo Daniel Sanches e Thaís Harumi Manfré Yado, por terem sido tão companheiros no processo de coleta dos fatos discursivos, de escrita e de revisão da tese.

À Thais de Araujo da Costa, José Edicarlos de Aquino, Aline Fernandes de Azevedo, Mabel de Morais Lopes e Maurício Cardoso Santos, pela nossa amizade e parceria/apoio nas pesquisas, que tornaram o estágio doutoral mais produtivo e alegre. Agradeço por mantermos nossos laços, ainda que estejamos distantes territorialmente.

À Monsieur Christian Puech, pour l'accueil aimable dans les activités du "Laboratoire d'Histoire des Théories Linguistiques" (HTL), dans l'Université Paris III - Sorbonne Nouvelle et dans l’Université Paris VII - Diderot.

À Maria de Lourdes Dias Fontes, mon cher professeur de français. Je vous remercie pour m'accompagner tout le temps d'une manière très généreuse. 
À Fernanda Correa Silveira Galli, Ane Ribeiro Patti e Ludmila Ferrarezi, por serem farol para minha pesquisa. À Caio Garcia Carniel, Kamila Alves e Tayla Agostinho, pelas discussões no cartel, que muito ajudaram a compor essa tese. À Cynara Maria Andrade Telles, pela nossa interlocução. À Alice Costa Macedo, Samuel Ponsoni e William Righini de Souza pela ajuda com a documentação do "estágio sanduíche".

À minha analista Cristiana Chacon Gallo, pela escuta.

Aos membros de "Lalíngua - espaço de interlocução em Psicanálise" pelo percurso psicanalítico que estamos elaborando.

À coordenadora do Programa da Pós-Graduação em Psicologia da FFCLRP/USP, professora doutora Sônia Regina Pasian, e aos caros professores desse Programa de Pós-Graduação.

Aos funcionários da USP, especialmente Jacqueline Côrrea e Maria Inês Joaquim, pelo atendimento cordial e eficiente.

Ao Programa de Doutorado Sanduíche no Exterior (PDSE/CAPES - Processo BEX10793/143), pela concessão da bolsa de estudos, sem a qual não teria sido possível realizar o estágio de doutorado na Université Paris XIII - Nord, sob supervisão do professor doutor Éric Bidaud.

À CAPES pela bolsa de estudos pelo Programa Demanda Social.

Aos meus queridos pais, Jair Roberto Giorgenon e Terezinha Giroto Giorgenon, pelo apoio tão fundamental para que eu pudesse chegar até aqui. Agradeço cada gesto, cada palavra de incentivo e de amor.

Às minhas irmãs, Ana Paula Giorgenon e Lucimara Giorgenon, e aos meus sobrinhos, Bruno Giorgenon Silva e Lucas Giorgenon Silva, pelo apoio, sempre.

Aos amigos e familiares que acompanharam esse percurso. 
De nada adianta negar essa necessidade (desejo) de aparência, veículo de disjunções e categorizações lógicas: essa necessidade universal de um 'mundo semanticamente normal', isto é, normatizado, começa com a relação de cada um com seu próprio corpo e seus arredores imediatos (e antes de tudo com a distribuição de bons e maus objetos, arcaicamente figurados pela disjunção entre alimento e excremento).

(Pêcheux, 2008, p. 34)

Seja como for, esta pequena intervenção é para que não fiquem tranquilos quanto às suas relações com a latusa. (Jacques Lacan, 1992, p. 172) 


\section{RESUMO}

Objetivamos estudar sentidos sobre a relação sujeito, corpo e objetos tecnológicos de conexão à rede eletrônica, mais especificamente, questões que visam a compreender o processo de produção de discursos e sentidos sobre um corpo fusionado, silenciado e ilimitado na relação com esses objetos. Partimos do pressuposto de que o corpo e o objeto ganham contornos discursivos diferentes a cada contexto sócio-histórico. Porém, ressaltamos também que há relações repetitórias em qualquer contexto sócio-histórico. Como a busca do sujeito por uma complementariedade na relação com o objeto (Freud, 1930/2010; Lacan, 1995, 2005, 2008). Como a "necessidade de aparência", de um "mundo semanticamente normal", legitimando a estabilização de sentidos sobre qualquer objeto simbólico (Pêcheux, 2009a, 2009b, 2008). Nesse início de século, temos escutado discursos que legitimam a complementariedade com o objeto, na forma da nomeação "ciborgue", misto de organismo e máquina (Haraway, 2009), sobretudo em enunciados sustentados pelo poder do Mercado (Payer, 2005). A partir das questões que elencamos para estudar a referida relação, delineamos os capítulos de forma a abordar os conceitos de sujeito e discurso, objeto tecnológico e corpo, na interlocução com diversos campos do saber, mas norteadas pela Análise do Discurso e pela Psicanálise. Elaboramos a noção de uma posição do sujeito no discurso que nomeamos corpo (inter)face, para abordar a filiação a formação discursiva do mercado, produzindo sentidos sobre um corpo que é convocado a comparecer como interface do objeto tecnológico. As materialidades discursivas analisadas foram encontradas no período de agosto de 2012 a agosto de 2014, na rede eletrônica, por meio de buscadores como o Google e o DuckDuckGo e da rede social Facebook. Tecemos gestos de interpretação a discursos sobre diversos objetos tecnológicos de conexão à rede eletrônica, incluindo óculos e lentes de contato que prometem conexão à rede eletrônica e à realidade aumentada, objetos que se acoplam a face e ao olho e que nesse momento não estão deliberadamente ofertados nas vitrines, mas circulam em discursos na rede eletrônica e em feiras tecnológicas. Trabalhamos sentidos sobre: 1) o silenciamento do corpo no acoplamento com o objeto tecnológico de conexão à rede eletrônica, 2) sentidos sobre a invocação de partes do corpo para o acoplamento com o objeto tecnológico de conexão à rede eletrônica e destituição de outras partes e, 3) sentidos sobre a potencialização de partes do corpo no acoplamento com o objeto tecnológico de conexão à rede eletrônica. Concluímos essa pesquisa apontando a estabilização e a desestabilização dos discursos e sentidos sobre sujeito e corpo na relação com objetos tecnológicos de conexão à rede eletrônica, desnaturalizando os sentidos de potência atribuídos a um corpo cada vez mais inerte, que é dito tudo poder acessar na rede, se movimentar intensamente no virtual, ao passo que só precisará movimentar os olhos para se conectar à rede eletrônica e à realidade aumentada, ao objeto tecnológico se miniaturizar e se acoplar ao olho.

Palavras-chave: Sujeito. Discurso. Objeto. Corpo. Rede eletrônica 


\section{RÉSUMÉ}

Notre objectif est d'étudier les sens sur la relation sujet, corps et objets technologiques de connexion au réseau électronique, plus précisément, questions qui visent à comprendre le processus de production du discours et du sens sur un corps fusionné, qui est mis en silence et illimité dans la relation avec ces objets. Nous partons de l'hypothèse que le corps et l'objet gagnent des contours discursifs différents dans chaque contexte socio-historique. Toutefois, nous soulignons aussi qu'il y a des relations qui sont répétitives dans n'importe quel contexte socio-historique. Comme la recherche du sujet pour une complémentarité avec l'objet (Freud, 1930/2010; Lacan 1995, 2005, 2008). Comme "le besoin d'apparence", d'un "monde sémantiquement normal", en légitiment la stabilisation des sens sur n'importe quel objet symbolique (Pêcheux, 2009a, 2009b, 2008). Au début de ce siècle, nous avons entendu des discours qui légitiment la complémentarité avec l'objet, sous la forme de la nomination "cyborg", mélange de corps et de machine (Haraway, 2009), surtout dans les énoncés, soutenus par le pouvoir du Marché (Payer, 2005). En partant des questions que nous avons énumérées pour étudier cette relation, nous avons décrit des chapitres afin d'aborder les notions du sujet et du discours, de l'objet technologique et du corps, en dialogue avec les différents domaines de la connaissance, mais guidé par l'Analyse du Discours et par la Psychanalyse. Nous avons développé la notion de position du sujet dans le discours que nous avons appelé corps (inter)face, pour aborder l'affiliation à la formation discursive du marché, produisant des sens sur un corps qui est convoqué à comparaître comme interface d'objet technologique. Les matérialités discursives ont été trouvées pendant la période d'août 2012 à août 2014, sur le réseau électronique, par le biais du moteur de recherche Google et DuckDuckGo et du réseau social Facebook. Nous tissons des gestes d'interprétation aux discours sur divers objets technologiques de connexion au réseau électronique, qui compris les lunettes et les lentilles de contact qui promettent la connexion avec le réseau électronique et avec la réalité augmentée, objets qui s'appliquent sur le visage et les yeux, qui actuellement ne sont pas délibérément présentées dans les vitrines, mais qui circulent dans les discours sur le réseau électronique et dans les foires technologiques. Nous travaillons les sens sur 1) le silence du corps dans le couplage avec la technologie de connexion au réseau électronique, 2) l'invocation de parties du corps pour le couplage avec la technologie de connexion au réseau électronique et de la destituition d'autres parties et 3) les sens sur la potentialisation des parties du corps dans le couplage avec la technologie de connexion au réseau électronique. Nous avons conclu cette recherche en notant la stabilisation et la déstabilisation des discours et du sens sur le sujet et le corps dans la relation avec les objets technologiques de connexion au réseau électronique, en rendant opaque les sens du pouvoir attribués à un corps de plus en plus inerte, qui est censé être en mesure d'accéder à tout sur le réseau électronique, se déplacer dans le virtuel, au fur et à mesure, qui aura seulement besoin de déplacer les yeux pour faire la connexion avec le réseau électronique et la réalité augmentée, dans la mesure où l'objet technologique devient petit et s'attache à l'œil.

Mots-clés: Sujet. Discours. Objet. Corps. Réseau Électronique 


\section{LISTA DE IMAGENS CAPITULARES}

Capa - Cell XVI Portrait (Louise Bourgeois, 2000) - Recuperado em 08 de fevereiro de 2016, de http://masdearte.com/louise-bourgeois-y-antoni-tapies-elreencuentro/

Introdução - Eyes (Louise Bourgeois, 2001) - Recuperado em 19 de junho de 2014, de http://www.oddthingsiveseen.com/2010/08/photo-essay-louise-bourgeoiseyes.html.

Capítulo 1 - Natury Study (Louise Bourgeois, 1986) - Recuperado em 11 de junho de 2014, de https://www.nationalgalleries.org/whatson/exhibitions/artist-roomslouise-bourgeois-a-woman-without-secrets/highlights-23510

Capítulo 2 - A Couple (Louise Bourgeois, 2003) - Recuperado em 30 de julho de 2014, de http://matome.naver.jp/odai/2130634396127851201

Capítulo 3 - Arch of Hysteria (Louise Bourgeois, 1993) - Recuperado em 20 de junho de 2014, de https://danilojove.wordpress.com/2010/06/01/louise-bourgeois/....

Capítulo 4 - Cell XXVI (Louise Bourgeois, 2003) - Recuperado em 30 de abril de 2015 , http://www.domusweb.it/en/news/2015/02/25/louise_bourgeois_the_cells.html.........

Capítulo 5 - Rejection (Louise Bourgeois, 2001) - Recuperado em 30 de agosto de 2014, de http://www.moma.org/explore/collection/lb/about/chronology

Considerações Finais - Mother and Child (Louise Bourgeois, 1970) - Recuperado em 08 de janeiro de 2016, de http://ultimosegundo.ig.com.br/cultura/artista+definitiva+do+seculo+20+louise+bou rgeois+e+revista+em+sp/n1597068579481.html

Referências - Clutching (Louise Bourgeois, 1962) - Recuperado em 24 de junho de 2014, de http://www.tate.org.uk/whats-on/exhibition/louise-bourgeois/roomguide/louise-bourgeois-room-5 


\section{LISTA DE IMAGENS NO CORPO DO TEXTO}

Figura 1 - Recuperado em 31 de outubro de 2013, de http://www.vicioweb.com.br/inicio/?tag=internet

Figura 2 - Recuperado em 17 de abril de 2014, de http://memesmigo.blogspot.com.br/2011_07_01_archive.html

Figura 3 - Recuperado em 12 de maio de 2014, de www.quadrinhosacidos.com.br... 56

Figura 4 - Recuperado em 22 de agosto de 2012, de http://tdodia.webnode.com.br/divers\%C3\%A3o\%20imagens/

Figura 5 - Recuperado em 16 de dezembro de 2015, de https://aconit.inria.fr/omeka/exhibits/show/histoire-machines/naissanceordinateur/eniac

Figura 6 - Recuperado em 04 de janeiro de 2016, de https://www.google.com.br/?gws_rd=ssl\#q=facebook

Figura 7 - Recuperado em 30 de outubro de 2015, de https://lh3.googleusercontent.com/S_OjtEhKHBtr1zZUARFimpPZzmW1rWbLdXv DDXydnOP2JbvhU8jZDW64JQf8eZ9s7VxtHK4=s87

Figura 8 - Recuperado em 5 de junho de 2013, de www.memetizando.com

Figura 9 - Recuperado em 18 de outubro de 2012, de http://www.cybertecturemirror.com/main.php?id=features

Figura 10 - Recuperado em 18 de outubro de 2012, de http://www.cybertecturemirror.com/main.php?id=features

Figura 11 - Recuperado em 07 de janeiro de 2014, de http://canaltech.com.br/noticia/google-glass/Google-Glass-deve-chegar-aomercado-em-2014-e-custar-menos-que-o-iPhone/\#ixzz38uOBa7RW>

Figura 12 - Recuperado em 04 de agosto de 2013, de http://blogs.estadao.com.br/homem-objeto/files/2013/08/googleglass.png>

Figura 13 - Recuperado em 10 de junho de 2013, de http://tecnologia.terra.com.br/noticias/0,,OI2246293-EI12882,00Estudo+desenvolve+lente+de+contato+que+acessa+web.html

Figura 14 - Recuperado em 10 de janeiro de 2014, de http://jornalggn.com.br/noticia/lentes-de-contato-inteligentes-garantem$\%$ E2\%80\%9Cvisao-sobre-humana\%E2\%80\%9D 
Figura 15 - Recuperado em 04 de fevereiro de 2013, de http://tv.estadao.com.br/videos,A-INTERNET-E-O-SISTEMA-NERVOSOCENTRAL-DA-SOCIEDADE-AFIRMA-ASSANGE,193887,0,0.htm?pagina=46 ..

Figura 16 - Recuperado em 27 de outubro de 2015, de http://kerdonis.fr/ZPIC02/page2.html

Figura 17 - Recuperado em 20 de janeiro de 2015, de https://www.google.com/culturalinstitute/asset-viewer/theambassadors/bQEWbLB26MG1LA?utm_source=google\&utm_medium=kp\&hl=pt$\mathrm{BR} \&$ projectId=art-project.

Figura 18 - Recuperado em 20 de novembro de 2012, de http://info.abril.com.br/noticias/blogs/gadgets/miscelanea/ja-pensou-em-usar-ainternet-pelo-espelho-do-banheiro/

Figura 19 - Recuperado em 23 de abril de 2014, de http://freakout.net.br/evolucao-riemann/. 


\section{SUMÁRIO}

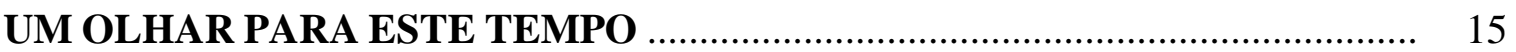

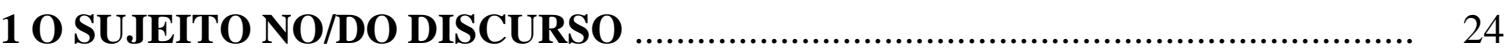

1.1 Michel Pêcheux e os efeitos de sentidos entre "interlocutores", quais sejam, Althusser, Lacan, Saussure e Foucault ……................................................... 25

1.2 Língua, a base para os processos discursivos ............................................... 31

1.3 Os processos discursivos como constituintes do sujeito e do discurso e por estes constituídos materialmente

1.3.1 O discurso, estrutura e acontecimento: no ponto de encontro de uma atualidade e uma memória

1.3.2 O real do discurso

1.40 sujeito e os processos de imposição/dissimulação e interpelação/identificação pelo poder do Mercado ........................................... 51

2 A NOÇÃO DE OBJETO: DE DAS DING AO OBJETO TECNOLÓGICO DE CONEXÃO À REDE ELETRÔNICA

2.1 Das Ding ou A Coisa - a, causa de desejo - os objetos da ciência e do mercado - o objeto do discurso

2.2 O objeto tecnológico e a rede eletrônica

2.2.1 A memória: a metálica e o Arquivo …..................................................... 85

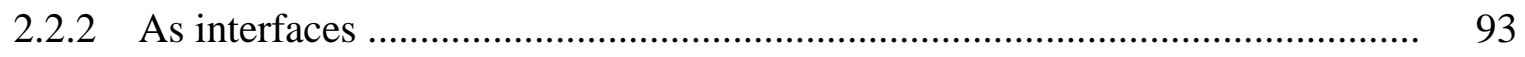

3 O CORPO NO/DO DISCURSO E O DISCURSO NO/DO CORPO ............... 107

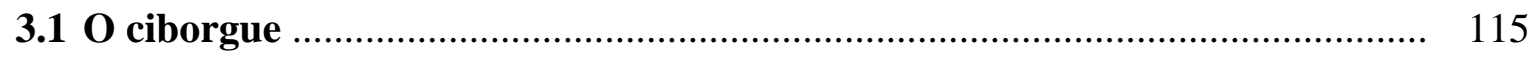

3.2 O corpo segundo a Psicanálise delineada por Freud e Lacan ........................ 123

3.3 O corpo segundo a Análise do Discurso delineada por Pêcheux ….................. 140

3.4 A posição-sujeito corpo (inter)face …....................................................... 149

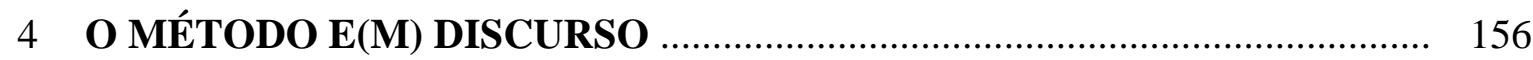

4.1 O processo de produção desta pesquisa ….................................................. 168 
5 INDÍCIOS DA FORMAÇÃO DISCURSIVA DO MERCADO, DA FORMASUJEITO DO MERCADO E DA POSIÇÃO-SUJEITO CORPO (INTER)FACE NO DISCURSO

5.1 Entrada Discursiva 1: Sentidos sobre o silenciamento do corpo no acoplamento com o objeto tecnológico de conexão à rede eletrônica

5.2 Entrada Discursiva 2: Sentidos de invocação de partes do corpo para o acoplamento com o objeto tecnológico de conexão à rede eletrônica e destituição de outras partes

5.3 Entrada Discursiva 3: Sentidos de potencialização de partes do corpo na conexão com o objeto tecnológico de conexão à rede eletrônica

PORQUE O CORPO NÃO É O "DOMINGO DO PENSAMENTO" 209

REFERÊNCIAS 216 


\section{UM OLHAR PARA ESTE TEMPO}

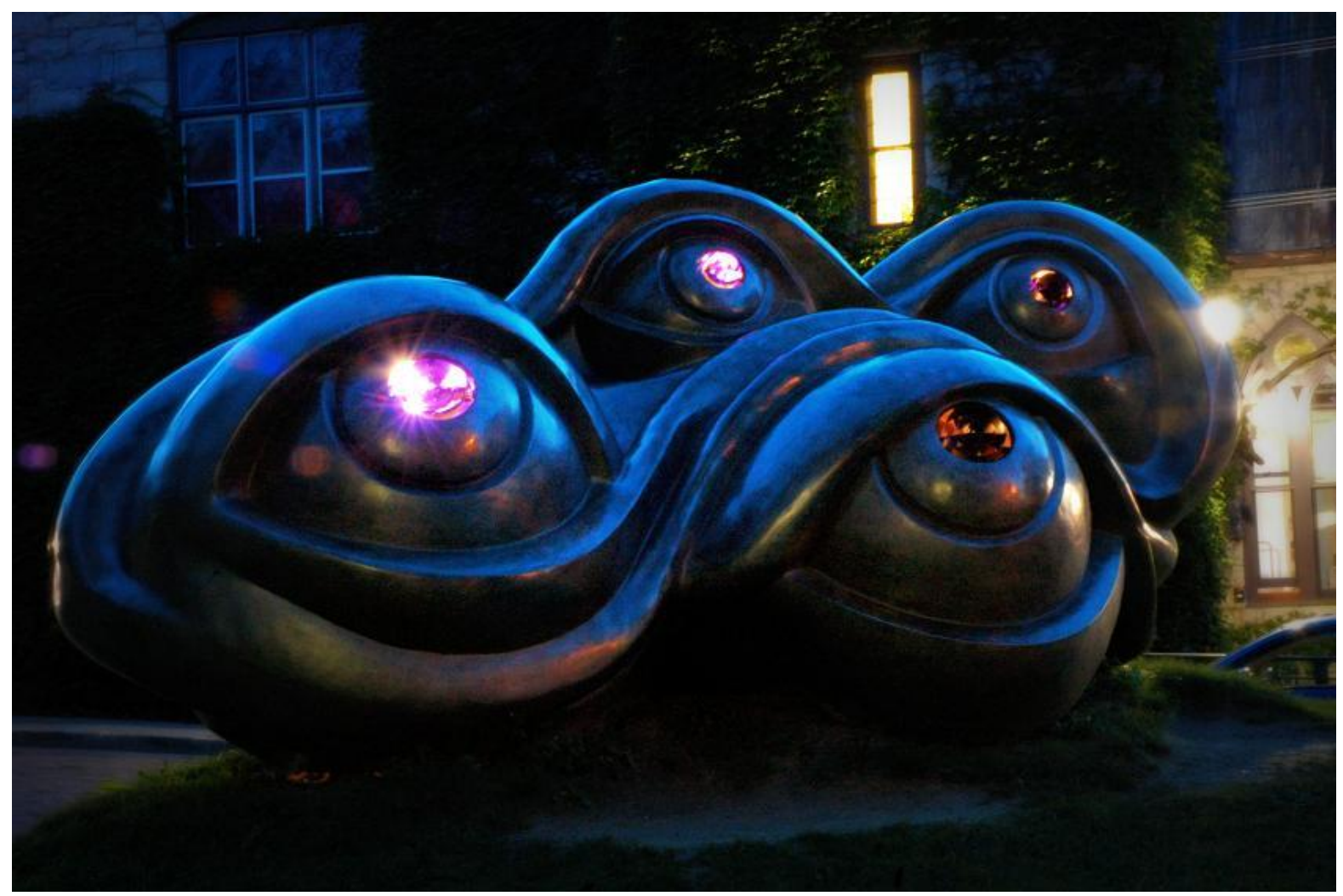

Eyes (Louise Bourgeois, 2001)

O Outro lado

Como serão as coisas quando não estamos a olhar para elas? [...]

(Saramago, 2009, p. 52) 
Esta pesquisa nasce da convergência de estudos sobre discursos e sentidos legitimados sobre o corpo na pós-modernidade. Na dissertação de mestrado "Sentidos de inclusão e exclusão na voz de sujeitos-escolares: o deslocamento do déficit pela via da falta" (Giorgenon, 2011), estudamos discursos sobre crianças e adolescentes considerados com deficiência, na inclusão escolar, e por meio da referida escrita sensibilizamos nossa escuta à imputação de déficit ao corpo. Nos estudos realizados no "Laboratório Discursivo: sujeito, rede eletrônica e sentidos em movimento - E-1@dis”, voltando nossa escuta ao campo da cibernética, encontramos materialidades discursivas na rede eletrônica que sustentam sentidos de potência e não potência ao corpo ao, respectivamente, estar ou não estar conectado a um objeto tecnológico de conexão à rede eletrônica. Tal escuta nos levou a levantar questões sobre a imputação de déficit ao corpo, para além dos sentidos já legitimados nos padrões de normalidade, norteados nesse momento não pelo discurso médico, mas pelo poder do Mercado (Payer, 2005) e seus enunciados sustentados pela mídia, que imbuem os produtos da ciência, os gadgets, com sentidos de potência.

$\mathrm{Na}$ opacidade do encontro dessas pesquisas, adveio o desejo de estudar os discursos sobre a relação sujeito, corpo e objetos tecnológicos de conexão à rede eletrônica, ao passo que encontramos diversas materialidades na rede eletrônica que apresentavam o corpo fusionado a máquina, o corpo silenciado perante a máquina e o corpo ilimitado na conexão com a máquina. Três questões, portanto, nortearam todo o processo de produção da pesquisa "Corpo (inter)face: sentidos sobre a relação sujeito, corpo e objetos tecnológicos de conexão à rede eletrônica", ou seja, sua constituição e formulação:

1) Como os discursos sobre os objetos tecnológicos de conexão à rede eletrônica fazem do corpo uma peça acoplada, unindo o corpo e a máquina?

2) Como os discursos sobre os objetos tecnológicos de conexão à rede eletrônica tornam o corpo silente, ao passo que é movente na rede?

3) Como os discursos sobre os objetos tecnológicos de conexão à rede eletrônica tecem sentidos sobre o corpo como não tendo limite para o gozo com o objeto, o acoplamento, o acesso?

Por meio dessas questões, objetivamos escutar como se dá o processo de constituição dos sentidos legitimados na pós-modernidade sobre o corpo na relação com objetos tecnológicos de conexão à rede eletrônica e discursar sobre alguns de seus efeitos, no corpo, na posição que o sujeito ocupa nos discursos. Em um tempo em que passar dias na fila para comprar o novo gadget lançado pelo Mercado se torna discursivamente como algo da ordem da necessidade e do poder. Em um tempo em que não se questiona a aplicabilidade de objetos 
tecnológicos que cada vez mais se acoplam ao corpo e se ventilam discursos de potência ao corpo conectado ao objeto. Em um tempo em que se vendem esses discursos e se compram esses discursos, há que se levantar questões. Principalmente sobre a naturalização de sentidos sobre um corpo mítico que necessita apenas de algumas partes/órgãos para se conectar e é dito movente no virtual, é dito tudo poder, tudo poder ver.

Para contemplar este tempo, buscamos não nos fixar tanto em nossa época, e para isso, acessamos a historicidade, seja do corpo, seja do objeto (tecnológico), para percebermos que o corpo e o objeto ganham contornos discursivos diferentes a cada contexto sócio-histórico. Porém, há relações que são repetitórias em qualquer contexto sócio-histórico, que é a busca do sujeito por uma complementariedade na relação do corpo-objeto, do objeto-corpo, bem delineadas por Freud (1930/2010) e Lacan (1995, 2005, 2008), no campo da Psicanálise, e a questão da necessidade de aparência, de um "mundo semanticamente normatizado" pairando nos diversos contextos produzindo dadas condições para a criação de discursos, legitimadas ideologicamente, fato bem delineado por Pêcheux (2009a, 2009b, 2008), no campo da Análise do Discurso, ao perscrutar o processo de produção de discursos e sentidos. Assim, seguimos apontando como os discursos, autorizados a circular em dados contextos, atravessam a relação do corpo com os objetos.

Arriscamos uma produção que visa a trazer contribuições ao campo conceitual e analítico da Análise do Discurso, da Psicanálise, e, sobretudo, trazer contribuições ao modo de se olhar para os discursos que circulam na pós-modernidade sobre o corpo na relação com objetos tecnológicos de conexão à rede eletrônica, de modo a opacizar sentidos que estão sendo naturalizados, contando, com um olhar e uma escuta que almejamos ser "contemporânea". Apoiadas em Agamben (2009), nos filiamos ao conceito de contemporâneo, tomando-o como diferente de "pós-moderno". Este, uma marca cronológica no tempo, enquanto aquele se caracteriza por um modo de olhar que se desprende do controle temporal, embora no tempo se situe. O filósofo afirma que a contemporaneidade não é datada, é uma relação singular com o tempo, uma relação que adere ao tempo e dele se distancia. Assim, aqueles que muito aderem à sua época, não são contemporâneos, porque não conseguem vê-la; o contemporâneo mantém o olhar no seu tempo para nele perceber o escuro e não as luzes, mergulhando nas obscuridades.

Aponta ainda que o contemporâneo não se deixa cegar pelas luzes do seu século e percebe o escuro do seu tempo como algo que lhe atravessa e não cessa à interpretação, captando um outro ponto de luz na obscuridade. Tentando lançar-nos a descrição e a interpretação nesse trabalho de escuta e de olhar ao corpo, atravessado pelo conceito de contemporâneo trazido por Agamben (2009), tecemos nossos capítulos de modo a traçar uma 
direção para abarcarmos a escuridão do que há na relação sujeito, corpo e objetos tecnológicos de conexão à rede eletrônica, visando alguma outra luz. Os capítulos foram delineados a partir das três questões que elencamos para nortear nossa pesquisa e, para tanto, buscamos abordar os conceitos de sujeito, objeto tecnológico e corpo, apresentados nos três primeiros capítulos, os quais contaram com gestos de interpretação a algumas materialidades discursivas encontradas na rede eletrônica. Posteriormente, apresentamos o processo de produção desta pequisa e o método da Análise do Discurso, para, a seguir, estabelecermos gestos de interpretação a materialidades discursivas que tecem sentidos sobre objetos tecnológicos de conexão à rede eletrônica que prometem também acesso à realidade aumentada ao se acoplarem em partes do corpo, mais especificamente, na face e nos olhos. Sobre cada capítulo temos a dizer o que se segue.

No capítulo 1, discorremos sobre o sujeito no/do discurso, primeiramente apresentando os efeitos de sentido da constituição da Análise do Discurso no entrelaçamento teórico (com o Materialismo Histórico, a Psicanálise, a Teoria do Discurso e a Linguística) que produziu essa disciplina de interpretação singular na década de sessenta, em um gesto inaugural empreendido por Michel Pêcheux, na França. Apresentamos a relação que o fundador da Análise do Discurso estabelece entre língua, ideologia e insconsciente nos processos de imposição/dissimulação que assujeitam o sujeito e, por isso, o constituem sob a incidência do recalque do inconsciente e da formação ideológica dominante que reverbera em cada contexto sócio-histórico, ou seja, o sujeito assujeitado ao Sujeito universal e ao Outro. Assinalamos que a formação ideológica se pulveriza em formações discursivas materializadas no discurso de sujeitos, que, se filiam às formas-sujeito representantes das formações discursivas e com as quais se posicionam identificando-se, contraidentificando-se ou desidentificando-se, compondo posições plurais no discurso. (Pêcheux, 2009a, 2009b).

Abordamos o discurso como efeito de sentidos e como estrutura e acontecimento, contornado pela memória, aquela que compõe sentidos enredada à exterioridade do discurso, sob a repetição, a regularização e o acontecimento discursivo, que desregula a série discursiva (Pêcheux, 1999, 2008). Abordamos o silêncio, conforme Orlandi (2007a): o silêncio fundador inerente às palavras e a política do silêncio vinculada a colocar em silêncio, a qual se manifesta tanto no silêncio constitutivo do sujeito - posto que para dizer é preciso não dizer outras palavras -, quanto no silêncio local, que é a proibição de um dizer. A partir da leitura de Payer (2005) sobre o contexto sócio-histórico que nos atravessa, apontamos que o Mercado é o grande Sujeito que nos interpela ideologicamente, produzindo uma nova forma de sujeito, a partir dos enunciados legitimados pelo poder do Mercado. Também abordamos o discurso do mercado 
pelo viés da Psicanálise como aquele regido pelos objetos tecnológicos produzidos pela ciência e alavancados pelo discurso do mercado (Braunstein, 2010).

No capítulo 2 abordamos o que concebemos como objeto tecnológico e como rede eletrônica em uma visão que se desloca do campo informático e cibernético para o campo da Análise do Discurso e da Psicanálise. Apresentamos então a noção de objeto para a Psicanálise, a relação do sujeito com o objeto (seja ele qual for, o objeto eleito pelo sujeito, podendo ser de qualquer materialidade), relação na qual o sujeito espera encontrar um objeto que preencherá sua falta, o qual Freud (1895[1950]/1996f) nomeou Das Ding e que Lacan (2005), em sua releitura, nomeou como objeto $a$, um objeto inexistente mas que é enlaçado a algumas formas às quais o sujeito se lança para tentar preencher sua falta a ser. Na esteira desse conceito, apontamos que consideramos objeto tecnológico qualquer invenção humana que tenha o objetivo de aprimorar órgãos, tal como Freud (1930/2010) definiu os instrumentos criados pela ciência, que Lacan (1992) denominou "latusas" e Braunstein (2010), "servomecanismos".

Apresentamos brevemente a história do primeiro computador e traçamos alguns rastros sobre a miniaturização dos objetos tecnológicos até o acoplamento ao corpo, o acoplamento a partes do corpo, essas sendo convocadas a ser interface direta na relação com o objeto. Abordamos a rede eletrônica a partir do conceito de discurso, em seus fios, nós e furos, apoiadas em conceitos da Análise do Discurso como a memória metálica (Orlandi, 2007b, 2006) e o Arquivo (Romão, 2012). Apresentamos o que se concebe como interfaces no campo da Informática e da Cibercultura e, sobretudo, discorremos sobre a tela do objeto tecnológico, como interface touch, e sobre o seu deslocamento para o olho, na medida em que esse é convocado a ser interface direta dos objetos tecnológicos vestíveis que estudamos, quais sejam, os óculos e as lentes de contato que conectam a rede eletrônica e proporcionam a chamada realidade aumentada, dispensando as tradicionais telas, posto que as imagens são projetadas diretamente na retina. Assinalamos que, ao passo que os objetos tecnológicos se acoplam a face e principalmente ao olho, convocando-os a ser interface, discursos sustentam a possibilidade de uma "visão sobre-humana" com a oferta da "realidade aumentada". No gesto de interpretação empreendido nesta pesquisa, assinalamos um empuxo à visibilidade nesse contexto sóciohistórico, já apontado por Debord (2003) na década de sessenta, e que se atualiza na convocação do olho, como órgão, a assumir uma posição de potência no discurso ao ser interface do objeto tecnológico.

\footnotetext{
${ }^{1}$ Recuperado em 10 de janeiro de 2014, de http://jornalggn.com.br/noticia/lentes-de-contato-inteligentesgarantem-\%E2\%80\%9Cvisao-sobre-humana\%E2\%80\%9D
} 
No capítulo 3, dedicado ao corpo em discurso, apresentamos inicialmente a historicidade do corpo, assinalando como as condições de produção trabalham na constituição de sentidos sobre o corpo. Estudamos com Corbin, Courtine e Vigarello (2008), com Mauss (1974), com Leandro-Ferreira (2013) e com Dias (2012), os diferentes modos de se discursivizar sobre o corpo. Assinalamos que a partir do século VII, o corpo é atrelado discursivamente ao funcionamento das máquinas, já produzindo sentidos de uma (con)fusão entre corpo e máquina, mistura já presente no imaginário dos humanos e na história, como por exemplo, na criação dos autômatos da Idade Média. Apresentamos sentidos sobre o ciborgue, termo surgido na década de sessenta para nomear a relação corpo-máquina, e ao qual associamos a busca de um corpo semanticamente normatizado (seguindo a concepção de Pêcheux (2008) de um "mundo semanticamente normal"), um corpo ideal, que, assim sendo, não é mais concebido como corpo e sim ciborgue. Para tecermos sentidos sobre o ciborgue nos pautamos em Robin (2000), Le Breton (2003), Haraway (2009), Lemos (2010) e salientamos que esse é um modo de tecer sentidos sobre o corpo que tenta tamponar o impossível do corpo.

Apresentamos a noção de corpo para a Psicanálise, para a qual o corpo é concebido como pulsional e contornado por linguagem. Pautando-nos em Freud (1923/1996e), apresentamos o corpo como uma dispersão de órgãos, e assinalamos que as percepções dão indícios para a constituição do eu e do corpo. Com Lacan (1998c), delineamos a constituição do eu a partir do estádio do espelho, por meio do qual o infans concebe uma imagem totalizante de seu corpo. Assinalamos também o quanto o despedaçamento do corpo e a noção de inteireza retornam durante toda a vida do sujeito nos sintomas, e o quanto comparece nos discursos sobre o corpo e os objetos tecnológicos de conexão à rede eletrônica que estudamos, os quais se acoplam a partes do corpo. Como aponta Lacan (2005), nem tudo passa ao espelho, restando o objeto $a$, que toma a forma de objetos parciais, dos quais destacamos o olho e a voz, por serem objetos eleitos na relação sujeito, corpo e objetos tecnológicos, que nos dedicamos a estudar, sobretudo na relação com os óculos e as lentes de contato que conectam a rede sob o comando de piscar de olhos, toque e voz. Assinalamos a diferença entre o olho e o olhar e a não captura total do olhar, principalmente para opacizarmos os sentidos de potência atribuídos ao olho que é convocado a ser interface do objeto tecnológico.

Apresentamos a noção de corpo para a Análise do Discurso, que, segundo Orlandi (2012b), é uma produção decorrente da interpelação ideológica, assim como o sujeito. Conforme essa autora, o corpo é produzido pelo discurso e produz discurso, interessando à Análise do Discurso o modo de sua constituição em cada contexto sócio-histórico, atravessado pela forma-sujeito histórica, que sinaliza sua afetação pela sociedade de consumo em nosso 
tempo. Com Dias (2008), apresentamos o conceito de corpografia, com o qual a autora aborda o comparecimento do corpo via grafia no virtual, espaço onde o corpo é impossibilitado de comparecer de fato. Assim, sua inscrição se dá via escrita corpográfica. Gallo e Romão (2011) abordam o corpo como opaco e incompleto, atravessado pelas ilusões constituivas e pelas formações imaginárias. Assinalam como os sentidos sobre a rede eletrônica incidem no corpo, constituindo efeitos de naturalização de um corpo sem limites, online o tempo todo, tudo podendo encontrar na rede. Azevedo (2013a, 2013b) assinala como tecnologias corporais, modos de inscrever sentidos sobre o corpo constituídos a partir dos discursos sobre as tecnologias que criam efeitos de um corpo sem exterioridade, como se a ideologia não mediasse a relação com as máquinas. A partir de toda a teorização exposta, apresentamos a posiçãosujeito corpo (inter)face, enlaçando a teoria estudada ao que temos escutado nas materialidades discursivas que encontramos na rede eletrônica. Tal posição-sujeito se identifica com a formação discursiva do mercado e a forma-sujeito do mercado, as quais formulamos a partir das contribuições de Payer (2005).

A posição-sujeito corpo (inter)face é posição na qual ressoa o corpo como interface do objeto tecnológico, e, de modo mais específico, a face e os olhos como partes do corpo legitimadas ao acoplamento com o objeto tecnológico óculos e lente de contato que conecta a rede eletrônica e propicia a realidade aumentada. Abordamos sentidos sobre o corpo como interface, sendo discursivizado como ciborgue, misto de carne e tecnologia, e sendo silenciado como corpo faltante ao passo que é discursivizado como potente ao ser interface do objeto tecnológico. Apontamos também que, além da face ser convocada a comparecer como interface, sentidos sobre o "Facebook" - rede social que opera com um perfil do sujeito (um livro de rosto/face), sujeito que se acredita todo sendo parte na/da rede -, se presentificam na relação com o objeto tecnológico, ao se supor um corpo "todo" no virtual. Destacamos, ainda, nesta posição corpo (inter)face, que a partícula “inter” aponta não só sentidos ligados a internet, mas também faz ressoar o "entre" na medida em que ressaltamos um intervalo no discurso, que pela via da falta, faz o corpo comparecer não só como ciborgue, via a porosidade do silêncio. Assim, é possível dizer de um corpo tal qual propõe a Análise do Discurso e a Psicanálise, que ainda que barrado nos discursos que coletamos, comparece de algum modo pelo próprio silenciamento.

No capítulo 4, apresentamos o método da Análise do Discurso delineando, sobretudo, o movimento pendular do analista do discurso ao construir o seu dispositivo teóricometodológico, perpassando movimentos de ir e vir entre teoria e análise (Petri, 2013), até criar um efeito de fim a partir de gestos de interpretação que levem em conta a exterioridade, a 
incompletude da língua, do discurso e do sujeito. Apontamos a constituição do dispositivo analítico que, no caso dessa pesquisa, tratou de recortar do material bruto coletado recortes discursivos discursivos e imagéticos representativos de paráfrases, a partir das questões que constituíram a pesquisa, e por meio das quais delineamos o funcionamento enunciativo do objeto discursivo. Realizamos, então, uma escuta desfazendo o efeito dos esquecimentos que naturalizam a relação palavra-coisa e passamos a delinear a formação discursiva dominante, a forma-sujeito dominante e a posição-sujeito que se destaca nas enunciações. Assinalamos que as materialidades discursivas foram encontradas na rede eletrônica, navegando na rede social Facebook e também realizando buscas por meio dos buscadores Google e DuckDuckGo com palavras-chave como "gadgets", “corpo e internet", "tecnologias vestíveis". Como se poderá ver, os capítulos dessa pesquisa foram costurados no enlaçamento da teoria com análises, todavia, no capítulo 5 concentramos os gestos analíticos nos apropriando do conceito de posição-sujeito corpo (inter)face associado a forma-sujeito do mercado e a formação discursiva do mercado. Posição-sujeito que nos auxilia a compreender o processo de produção dos sentidos e dos discursos sobre o corpo, legitimados pela ideologia neste contexto sócio-histórico.

No capítulo 5, então, nos dedicamos às análises de 15 recortes discursivos, selecionados do material bruto coletado, representativos de paráfrases de discursos sobre a relação sujeito, corpo e objetos tecnológicos de conexão à rede eletrônica, mais especificamente discursos que abordavam os objetos tecnológicos óculos e lentes de contato que prometem conexão à rede eletrônica e realidade aumentada. Os recortes foram distribuídos em três entradas discursivas nomeadas: 1) Sentidos sobre o silenciamento do corpo no acoplamento com o objeto tecnológico de conexão à rede eletrônica. 2) Sentidos sobre a invocação de partes do corpo para o acoplamento com o objeto tecnológico de conexão à rede eletrônica e destituição de outras partes. 3) Sentidos sobre a potencialização de partes do corpo no acoplamento com o objeto tecnológico de conexão à rede eletrônica.

$\mathrm{Na}$ primeira entrada discursiva, apontamos como nos discursos sobre os referidos objetos tecnológicos o corpo é silenciado, ao passo que sentidos sobre ciborgue, ficção científica e ciência são legitimados para dizer do acoplamento do corpo ao objeto, funcionando como interface do objeto. Na segunda entrada discursiva, abordamos como, no modo de utilização dos objetos tecnológicos referidos, partes do corpo são inovacadas e partes são destituídas, produzindo-se discursivamente um corpo fragmentado, ao passo que é pleno no acoplamento, na interface. Na terceira entrada discursiva, acompanhamos como os discursos sobre o acoplamento do corpo com os objetos tecnológicos potencializam partes do corpo, sobretudo o campo do olho, ventilando sentidos de um olho que tudo pode ver, se acoplado ao 
objeto tecnológico. Nessas entradas, trabalhamos com os conceitos vislumbrados nos capítulos iniciais e trabalhamos com a posição-sujeito no discurso que nomeamos corpo (inter)face. Consideramos que, no processo de constituição de sentidos sobre a relação sujeito, corpo e objetos tecnológicos de conexão à rede eletrônica, a formação discursiva do mercado interpela os sujeitos de modo a reproduzir a univocidade nos discursos, silenciando o corpo faltante e o estranhamento na relação de assujeitamento/subordinação ao objeto tecnológico, e sobretudo, ao poder do Mercado (Payer, 2005).

Concluímos essa pesquisa apontando que o corpo não é o "domingo do pensamento", parafraseando Pêcheux (2008) que isso diz a respeito do humor e do traço poético, excluídos de estudos linguísticos que trabalham com "um mundo semanticamente normal", desconsiderando a desestabilização da língua, do sujeito, do discurso, ao que acrescentamos, do corpo, esse que tem sido considerado máquina, ciborgue, suporte da máquina, embebido em sentidos de potência. Apontamos, com isso, que a noção de corpo que concebemos, apoiadas na Análise do Discurso e na Psicanálise, o aborda como pulsante no cotidiano, tal como os atos falhos (Freud, 1996h), fazendo barra ao estar online o tempo todo, fazendo barra ao movimento paralisante de fazer "Um" (Lacan, 2003e) com o objeto, ainda que discursos insistam em afirmar um (corpo)ciborgue, sem limites na relação com o objeto tecnológico, convocando o sujeito a ver de olhos fechados, sem metáfora. 


\section{O SUJEITO NO/DO DISCURSO}

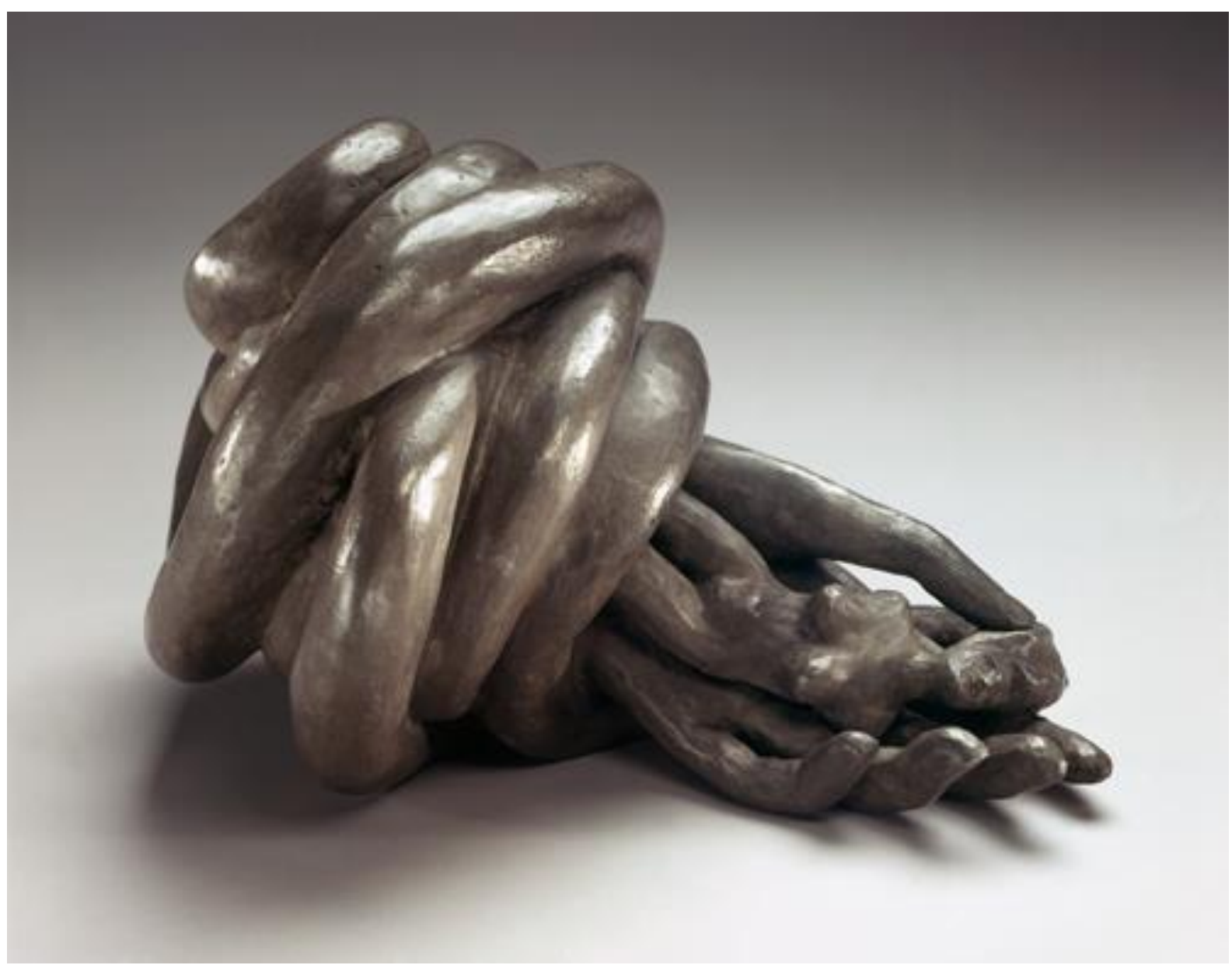

Nature Study (Louise Bourgeois, 1986)

Pura aparência

Suponho que no princípio dos princípios, antes de havermos inventado a fala, que é, como sabemos, a suprema criadora de incertezas, não nos atormentaria nenhuma dúvida séria sobre quem fôssemos e sobre a nossa relação pessoal e colectiva com o lugar em que nos encontrávamos. O mundo, obviamente, só podia ser o que os nossos olhos viam em cada momento, e também, como informação complementar importante, aquilo que os restantes sentidos - o ouvido, o tacto, o olfacto, o gosto conseguissem perceber dele. Nessa hora inicial o mundo foi pura aparência e pura superfície. A matéria era simplesmente áspera ou lisa, amarga ou doce, azeda ou insípida, sonora ou silenciosa, com cheiro ou sem cheiro. Todas as coisas eram o que pareciam ser pela única razão de que não havia qualquer motivo para que parecessem doutra maneira e fossem outra coisa. Naquelas antiquíssimas épocas não nos passava pela cabeça que a matéria fosse "porosa" [...].

(Saramago, 2009, p. 34-35) 
Sustentando as questões norteadoras dessa pesquisa, que aborda o processo de produção de sentidos sobre o corpo a partir dos discursos sobre objetos tecnológicos de conexão à rede eletrônica, e a posição-sujeito que advém desse processo, que compõe esse processo, está a Análise de Discurso delineada por Michel Pêcheux, em interlocução com as teorias que a constituíram - assim como outras teorias que contribuem para o fazer dessa pesquisa. Nesse capítulo, apresentaremos o processo de produção dessa disciplina de interpretação na década de sessenta, além dos processos de imposição/dissimulação que constituem o sujeito, o discurso e o sentido, a partir da interpelação ideológica e do recalque inconsciente.

Compreender os processos de imposição/dissimulação que assujeitam o sujeito ao mesmo tempo em que dissimulam o assujeitamento, fazendo com que acredite ser dono das palavras que profere é crucial para compreendermos como se dão os processos de produção de sentidos sobre o corpo, sobre os objetos tecnológicos de conexão à rede eletrônica, e sobre a posição-sujeito que advém da identificação à formação discursiva dominante que rege cada contexto sócio-histórico. Segundo Payer (2005), o grande Sujeito que interpela o sujeito na pósmodernidade é o Mercado. Segundo Braunstein (2010), autor da psicanálise, o discurso do mercado é aquele governado pelos "servomecanismos", ou seja, pelos objetos tecnológicos, ou ainda, pelos discursos que contornam esses objetos. A partir desses dois autores, podemos dizer que os objetos tecnológicos são imbuídos de sentidos e de discursos de potência, emoldurados pelo Mercado, sentidos que deságuam sobre sujeito e corpo. São, portanto, os discursos que ofertam lugares aos sujeitos, corpos e objetos. Para compreendermos esses processos de interpelação, abordamos conceitos como memória, acontecimento, silêncio, além dos já mencionados. Passaremos, neste momento, a abordar o processo de constituição da Análise do Discurso e, posteriormente, o arcabouço conceitual.

\subsection{Michel Pêcheux e os efeitos de sentidos entre "interlocutores", quais sejam Althusser, Lacan, Saussure e Foucault}

Segundo Plon (2012), na primavera de 1968, Pêcheux defendeu sua tese sobre a Análise Automática do Discurso, com a qual pretendeu revolucionar a análise de conteúdo de Harris. Conforme Mariani (2012), essa tese, publicada em 1969, representa uma virada na dominância da análise de conteúdo em vigor, nos pressupostos de leituras que leva(va)m em conta a literalidade do texto, que toma(va)m o sujeito como consciente de seus atos e que apaga(va)m 
a historicidade. É, então, no final da década de sessenta que Pêcheux alicerça uma teoria que concebe o discurso como "efeito de sentidos entre interlocutores" (Pêcheux, 2010, p. 81), na contramão de teorias linguísticas que se fechavam à pluralidade dos sentidos. O fundador apresenta uma proposta teórico-metodológica de base materialista, implicada com a utilização de programas de computadores (dos quais, Pêcheux abriu mão posteriormente), que leva em consideração o político e coloca em cena a posição-sujeito na produção discursiva e não a noção de indivíduo. Pêcheux (2011f, p. 277-278) em “Análise do Discurso e Informática” descreve que

O foco do programa da Análise Automática do Discurso (publicado em 1969 e informaticamente operacional a partir de 1971) constitui uma tentativa entre outras de realizar este objetivo esforçando-se para levar 'a linguística moderna' a sério, em particular F. Saussure, e os trabalhos do linguista americano Z. Harris [...].

Conforme Puech (2005), na França dos anos 60 e 70, o estudo de Saussure (e sobretudo do Curso de Linguística Geral dirigido por Bally e Sechehaye) é presentificado em todos os setores das ciências humanas e sociais e na filosofia, e sua presença também se materializou nos estudos de Pêcheux. Pautando-se em Saussure e em Harris, Pêcheux se dedicou à construção de procedimentos que visavam a reconstituir algo de uma estrutura invariante presente na série e, desse modo, tentava levar às últimas consequências a linguística harrisiana. Contudo, Pêcheux (2011f) logo se deu conta de alguns equívocos dos procedimentos da AAD69, os quais ficaram próximos das evidências empírico-lógicas da leitura, embora o objetivo fosse estabelecer uma outra leitura sobre língua, discurso e sujeito, diferente das até então legitimadas. Como nos conta Plon (2012), Althusser nem Lacan são citados nessa tese, porém, nos escritos posteriores de Pêcheux eles comporão a ponte teórica na qual o fundador da Análise do Discurso se movimentou até o final de sua vida.

Orlandi (2007b, p. 17) aponta que a singularidade do pensamento de Pêcheux se caracteriza pelo “[...] lugar particular que ele dá a língua [...]” na retomada da obra de Saussure, lugar em que relaciona a língua, de um lado à ideologia tratada no domínio do interdiscurso, retomando Marx e Althusser, e de outro, o inconsciente, na relação da língua com lalangue, retomando Freud e Lacan. Ao nosso ver, Pêcheux acrescenta o seu gesto de interpretação à produção de cada um dos autores que o provocaram a pensar a língua, o discurso, a posiçãosujeito e tantos outros conceitos que ele ressituou na disciplina que inaugurou.

Conforme Zoppi-Fontana (2013, p. 5, tradução nossa), 
A noção de interdiscurso, articulada às noções de formação discursiva, formação ideológica e acontecimento discursivo constituem o núcleo conceitual que permite a compreensão teórica e a descrição analítica da determinação histórica dos processos de significação e da constituição do sujeito discursivo. Saussure, Lacan e Althusser são os três grandes nomes que balizam a contrução da teoria da Análise do Discurso desenvolvida por Michel Pêcheux e seus colaboradores; o elemento crucial dessa construção se encontra na crítica bem fundamentada e feroz a uma concepção psicossocial ou biológica do sujeito e a uma abordagem pragmatizante da língua, que reduz o discurso a uma planificação estratégica de um sujeito intencional em situação de interação comunicativa. O estatuto histórico e ideológico do sentido, do sujeito e das diversas materialidades significantes é constitutivo do discurso, definido como efeito de sentido entre locutores. Por sua vez, o sujeito discursivo é compreendido como estruturalmente dividido, efeito de um processo de interpelação-identificação ideológica pelo qual se constitui no interior de diferentes formações discursivas, a partir das quais se reconhece na evidência de sentidos estabilizados como já-dito no interdiscurso. [...]. ${ }^{2}$

Nesta citação podemos acompanhar em que medida Saussure, Lacan e Althusser contribuem para que Pêcheux alicerce uma teoria que relacione e articule sujeito e discurso, ambos divididos, atravessados pelos efeitos da ideologia e do recalque inconsciente, constituídos no processo de interpelação-identificação. Segundo Plon (2012), no final da década de 60, diversos autores se debruçaram a estudar o conceito de discurso. Dentre eles, estão Althusser, Lacan e Foucault. Embora menos citado nessa seção e não tanto citado na obra pecheuxtiana, Foucault não deixa de ser um interlocutor, na medida em que ambos se debruçavam a estudar a teoria do discurso na mesma época e dividem de alguma forma a paternidade do conceito de formação discursiva (Baronas, 2007). Em "Metáfora e Interdiscurso", Pêcheux (2011g) reconhece a introdução do termo "formação discursiva" por Foucault e aborda as influências desse autor em seu pensamento: “[...] Podemos efetivamente pensar, a partir da Arqueologia do saber, uma concepção materialista da discursividade na qual

\footnotetext{
${ }^{2}$ La noción de interdiscurso, articulada a las nociones de formación discursiva, formación ideológica y acontecimiento discursivo constituyen el núcleo conceptual que permite la comprensión teórica y la descripción analítica de la determinación histórica de los procesos de significación y de la constitución del sujeto discursivo. Saussure, Lacan y Althusser son los tres grandes nombres que balizan la construcción de la teoría del Análisis del Discurso desarrollada por Michel Pêcheux y sus colaboradores; el elemento crucial de esta construcción se encuentra en la crítica bien fundamentada y feroz a una concepción psicosocial o biológica del sujeto y a un abordaje pragmatizante de la lengua, que reduzca el discurso a uma planificación estratégica de un sujeto intencional en situación de interacción comunicativa. El estatuto histórico e ideológico del sentido, del sujeto y de las diversas materialidades significantes es constitutivo del discurso, definido como efecto de sentido entre locutores. A su vez, el sujeto discursivo es comprendido como estructuralmente dividido, efecto de um proceso de interpelación-identificación ideológica por el cual se constituye en el interior de diferentes formaciones discursivas, a partir de las cuales se reconoce en la evidencia de sentidos estabilizados como ya-dicho en el interdiscurso. [...].
} 
efeitos do interdiscurso não se resolvem em um ponto de integração, mas se desenvolvem em contradições. É o que procurei fazer valer no Verités de La Palice [...].”.

Quanto às produções de Althusser, Lacan e Foucault, com o auxílio de Plon (2012), destacamos que em 1966, Althusser escreveu "Três notas sobre a teoria do discurso", publicado em 1993. Em 1969, Lacan se dedicava ao Seminário "O avesso da psicanálise”, no qual desenvolveu sua teoria dos quatro discursos, elaborando as diversas formas do laço social, e antes havia se dedicado ao seminário "De um Outro ao outro", no qual também trouxe importantes pontos sobre o conceito de discurso na psicanálise. Também em 1969, Foucault introduzia sua concepção de discurso. A década de sessenta, então, foi um contexto que possibilitou o processo de produção de questões sobre o discurso, em meio a ebulição política.

Embora Althusser, Foucault e Lacan tomassem o discurso por vias diferentes, um ponto comum em suas obras é o combate ao sujeito tomado como consciente pela psicologia, visando a subvertê-lo com a concepção de sujeito marcado pela descoberta freudiana (Plon, 2012), em que o eu é deslocado ao não ser senhor em sua própria morada (Freud, 1917/19961), um sujeito habitado pelo umheimlich, pelo estranho-familiar (Freud, 1919/1996d). Nessa via segue Pêcheux, também assim se posicionando e questionando o sujeito da psicologia em toda sua produção de modo direto ou indireto. Em "Nota sobre a questão da linguagem e do simbólico em psicologia", texto em co-autoria com Françoise Gadet, Claudine Haroche e Paul Henry (2011b); também em "Reflexões sobre a situação teórica das Ciências Sociais e, especialmente, da Psicologia Social" (Pêcheux, 2011a), texto que escreve como Thomas Herbert; e em "As Ciências Humanas e o "momento atual” (Pêcheux, 2011c); é essa a crítica que ele leva adiante. Em "Especificidade de uma disciplina de interpretação (A Análise de Discurso na França) o fundador delineia a Análise do Discurso:

[...] na medida em que ela se alinha entre as disciplinas de interpretação, colocando em causa a existência de um metadiscurso do sentido sob os discursos, a $\mathrm{AD}$ não pode se satisfazer com a concepção do sujeito cognitivo epistêmico, 'mestre em seu domínio' e estratégico em seus atos (face às coerções bio-sociológicas); ela supõe a divisão do sujeito como marca da inscrição no campo do simbólico. (Pêcheux, 2011d, p. 230).

Este é o ponto de enodamento destes autores com Pêcheux: uma crítica assídua à noção de sujeito cognitivo epistêmico e à transparência da língua. A partir desse enodamento e nesse enodamento, Pêcheux (1969/2010) concebe a Análise do Discurso como disciplina constituída a partir do enlace entre o materialismo histórico, a linguística, a teoria do discurso, articulados por uma teoria da subjetividade de natureza psicanalítica, não sem o seu gesto de interpretação 
a esses campos do saber, o qual levou às últimas consequências tomando "[...] partido pelo fogo de um trabalho crítico [...]" (Pêcheux, 2009b, p. 270), até sua morte em 1983. Para Plon (2012), embora a articulação psicanalítica seja mencionada na definição do quadro epistemológico da Análise do Discurso como um papel anexo, a concepção de discurso de Pêcheux mais se aproxima da teoria dos quatro discursos de Lacan - embora o fundador nunca tenha mencionado os seminários que Lacan dedicou à noção de discurso - do que da concepção de discurso de Althusser. Já para Baldini (2014, p. 118), a psicanálise, do modo como é discursivizada por Pêcheux, atravessa e enlaça os outros três campos do saber que norteiam a Análise do Discurso, e acrescenta que:

O modo como a Psicanálise comparece na obra de Michel Pêcheux é motivo
de discussão em perspectivas bastante variadas. Seja porque o campo da
Psicanálise aparece de maneira que às vezes não é explícita nos textos de
Pêcheux, seja porque a relação de Pêcheux com a Psicanálise nunca tenha sido
a de uma adesão sem críticas, seja porque a relação entre o Materialismo
Histórico e a Psicanálise tenha sido objeto de uma reflexão por vezes bastante
complexa pelo autor, o fato é que, a partir da obra de Pêcheux, embora a
Psicanálise não possa deixar de ser tematizada, diferentes posições com
referência ao quadro conceitual da Psicanálise podem ser inferidas.

Baldini (2014) destaca que a proposta pecheuxteana de um atravessamento psicanalítico em sua teoria é enigmática, porém, o ponto nodal de sua proposta foi pensar a relação da constituição do sujeito tal qual formulada pela psicanálise de Freud e Lacan e o assujeitamento ideológico, tal qual formulado por Althusser. Assinala que em vários momentos de sua obra “[...] Pêcheux reconhece o efeito de 'furo' do inconsciente em qualquer ritual de interpelação ideológica, ao mesmo tempo que atenta para o risco fácil de se fazer do inconsciente, agora, a origem da resistência das ideologias dominadas à ideologia dominante [...]” (p. 127).

Na visão de Plon (2012) sobre os “(des)enlaces” (Mariani, Romão \& Medeiros, 2012) entre Pêcheux e Lacan, e também Althusser, ele pontua que para Althusser, o discurso, seja ele qual for - científico, ideológico ou do inconsciente -, produz um efeito subjetivo, o que remete à noção de sujeito como efeito de subjetividade. Já para Pêcheux, a noção de discurso se apoia na linguística e no conceito de condições de produção, o que introduz a exterioridade, pela mobilização dos sujeitos e do objeto do discurso (Pêcheux, 2010) na relação com o contexto imediato e o contexto sócio-histórico que ampara o dizer, ou seja, as condições de produção. Sendo assim, sob o olhar de Pêcheux, o discurso "[...] não é a palavra de um sujeito, aqui entendido no sentido de indivíduo singular, mas uma produção presa nas contradições da língua 
e remetendo a lugares ou posições [...] em uma formação social dada e, portanto, ao conjunto de discursos possíveis." (Plon, 2012, p. 24).

Diferenciando e aproximando as noções de discurso estabelecidas por Althusser, Lacan e Pêcheux, Plon (2012) aponta que, com a teoria dos quatro discursos, Lacan aborda a estrutura do laço social, estrutura que sustenta que os elementos que a constituem têm propriedades apenas se ligados à posição que ocupam. E, ao seu ver, essa forma de repertoriar discursos lembra o modo como Pêcheux aborda os discursos, relacionando-o a dadas posições em cada formação social, embora o fundador da Análise do Discurso não leve em conta o matema circular de Lacan, no qual um discurso é causa e efeito do outro. No matema circular, Lacan (1992) distingue quatro discursos ${ }^{3}$ que são compostos por quatro elementos - a, S1, S2, \$ -, que podem se dispor em quatro lugares distintos - agente, verdade, Outro, produção ${ }^{4}$. Como podemos ver nas figuras nas notas de rodapé, a barra separa os elementos dispostos embaixo, recalca. Os elementos distribuídos em cada um dos quatro lugares distintos dão origem a um discurso: do mestre, da histeria, universitário e discurso do analista. A partir do discurso do mestre, Lacan (1992), ao inverter as posições de S1 e \$, formula a concepção de discurso capitalista, fundado sobre a noção de mais de gozar, apoiado em Marx.

O elemento $a$ que compõe cada discurso, é desmembramento do conceito de objeto $a$ que Lacan trabalha em toda a sua teoria, formalizando-o em cada momento de sua obra. $\mathrm{Na}$

3
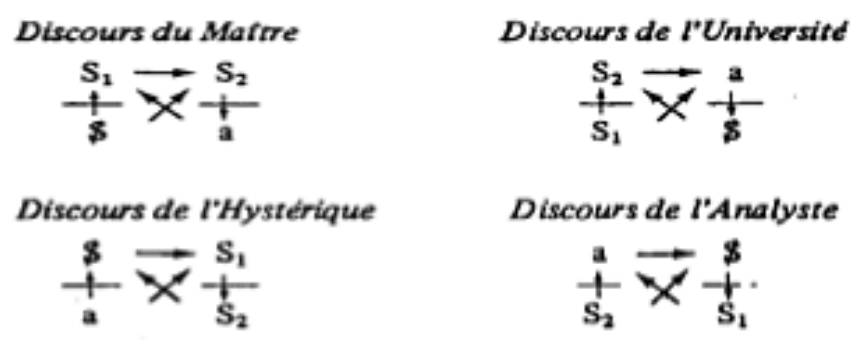

Discours du Capiraliste

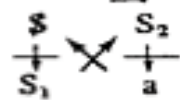

Recuperado em 14 de junho de 2014, de

http://www.proceedings.scielo.br/scielo.php?pid=MSC0000000032004000100019\&script=sci_arttext

$\frac{\text { agente }}{4 \text { verdade }} \rightarrow \frac{\text { Outro }}{\text { produção }}$

Recuperado em 14 de junho de 2014, de http://pepsic.bvsalud.org/scielo.php?script=sci_arttext\&pid=S167944272008000200002. 
concepção dos discursos, podemos observar que ele é o agente do discurso do analista e que estando em qualquer outra posição (ou ainda na mesma posição, mas sob vetores diferentes), embora represente a causa de desejo, ele pode não ter esse efeito no discurso pelo abafamento da posição em que se encontra. S1 (significante mestre) e S2 (saber) são os significantes representantes da cadeia discursiva e \$ é o sujeito. Lacan opera com esses quatro elementos na constituição do sujeito, na medida em que ele emerge entre significantes (S1 - S2), e pelo efeito da barra, deixa subtrair de si o objeto $a$, um resto que cai dessa operação de divisão. Sobre os discursos formulados por Lacan, Plon (2012, p. 27) enfatiza que “[...] essa conceitualização permite a Lacan desfazer qualquer ideia de uma extraterritorialidade do discurso analítico, para o qual ele afirma, ao contrário, a fragilidade, o risco permanente que ele corre, o de escorregar seja para o discurso acadêmico [...] seja para o discurso do mestre [...]”.

Conforme Mariani (2012), Pêcheux marcava a importância de uma ruptura com o modo de produção de conhecimentos de sua época, modo de produção que Lacan nomeou como discurso universitário, o qual toma como verdade um saber que se objetiva totalizador. Ao contrário desse saber totalizador, como veremos nas próximas sessões, Pêcheux se posiciona em seu percurso questionando as evidências, transformando o fazer acadêmico-universitário em uma prática que implica incessantes gestos de interpretação que mobilizam a teoria e a análise na ordem da (re)invenção. Gestos de interpretação que, para além de mobilizar os campos do saber que constituem a Análise do Discurso, trabalham pela singularidade do seu campo próprio, que não é nem o campo linguístico, nem o do materialismo histórico, nem o da

psicanálise. É um campo inaugural, (e)feito de discurso, de sentidos, não sem os interlocutores mencionados. Prosseguiremos abordando a noção de língua, sujeito, discurso e memória ao longo da produção do fundador.

\subsection{Língua, a base para os processos discursivos}

Pêcheux estabelece interlocução com a linguística em toda sua produção, mas uma interlocução que, ancorada principalmente em Saussure, não se equivoca como muitos póssaussirianos se equivocaram ao conceber a língua como um sistema fechado e ao deixar a divisão apenas em Saussure: aquele diurno, aquele noturno. A divisão própria à língua, ao discurso, ao sujeito é algo que o fundador da Análise do Discurso toma como mote para a teorização e análise, não se recusando a pensar o real da língua, aquilo que ele aponta como o 
objeto próprio da linguística que, no entanto, foi foracluído em pról de estudos sobre “[...] realidades psicossociológicas dos atos de linguagem [...]" (Pêcheux, 2010, p. 19). Ao contrário, o pensador francês se arrisca ao registro do real e também à contradição, tomando a língua como base para a constituição de processos discursivos.

De acordo com Pêcheux (2009a, p. 81), “[...] o sistema da língua é, de fato, o mesmo para o materialista e para o idealista, para o revolucionário e para o reacionário, para aquele que dispõe de um conhecimento dado e para aquele que não dispõe desse conhecimento [...]". Contudo, o fundador alerta que não podemos dizer que estes tenham o mesmo discurso. Desse modo, ele já anuncia a divisão, a contradição própria à(s) língua(s), ao(s) sujeito(s) e ao(s) discursos, e acrescenta que, sendo a língua a base para os processos discursivos, são os processos ideológicos que nela incidem que tornam os processos discursivos diferenciados. A língua é concebida como um pré-requisito para os processos discursivos e esses se constituem atravessados pelos processos ideológicos. Dito de outro modo, conforme Orlandi (2007a, p. $22)$, "[...] se o linguista pode dizer que a língua é indiferente ao discurso, pois tem sua autonomia relativa, ela se rege por leis internas, o analista de discurso dirá no entanto que o discurso não é indiferente à língua [...]” pois ele materializa o laço entre o ideológico e o linguístico e representa os efeitos das contradições ideológicas na e com a língua.

Tecendo diferenciações, Pêcheux (2009a, p. 82) assinala que "[...] a discursividade não é a fala (parole), isto é, uma maneira individual 'concreta' de habitar a 'abstração' da língua [...]", e, portanto, a noção de processo discursivo vem realocar a noção de fala. Salienta que a língua é indiferente à luta de classes, porém, as classes não são indiferentes à língua, pois “[...] todo processo discursivo se inscreve numa relação ideológica de classes [...]", o que confere à língua o lugar designado como a base, que sustenta os processos, e, sendo processos, são inacabados, não têm um sentido único, embora os sentidos não sejam quaisquer pelos efeitos das condições de produção do discurso. Em seu texto "Especificidade de uma disciplina de interpretação", Pêcheux (2011d, p. 28) destaca que "A posição epistemológica da Análise de Discurso conduz, então, a pensar na existência da língua não como um sistema (o software de um órgão mental!), mas como um real específico formando o espaço contraditório do desdobramento das discursividades".

Em “Língua, linguagens, discurso", Pêcheux (2011e) também traça uma discussão sobre a língua como base dos processos discursivos, diferenciando-a da linguagem, do discurso e da fala. Aponta que a base linguística caracteriza o funcionamento da língua em relação a si própria, e, em relação ao processo discursivo, o fundador assinala que é preciso considerá-lo em termos do funcionamento da base linguística em relação a representações postas em jogo 
nas relações sociais, o que permite compreender o fato de formações ideológicas diversas serem constituídas sobre uma única base, ou seja, uma língua, várias culturas.

Segundo Orlandi (2007a), quando a língua é concebida como sistema de formas abstratas, como a maioria dos linguistas a concebe, ela é tomada na ordem da transparência e da literalidade. Porém, quando a língua é concebida como materialidade, na Análise do Discurso, ela passa a ser estudada como materialidade linguística e lugar de comparecimento das relações de forças e de sentidos que refletem os confrontos ideológicos. Nas próximas sessões, veremos os efeitos de se pensar, assim, a língua e os processos discursivos, e, abordaremos, então, os conceitos de discurso e sujeito, advindos da concepção de língua, na qual trabalham o real e o equívoco, descentrando o sujeito da categoria do "[...] eu-consciência mestre do sentido [...]" para a noção de "[...] assujeitado ao discurso [...]" (Pêcheux, 2011g, p. 156) e apresentaremos com mais profundidade o conceito de formações ideológicas e sua materialização em formações discursivas, às quais se enlaçam os sujeitos por meio das formassujeito do discurso.

\subsection{Os processos discursivos como constituintes do sujeito e do discurso e por estes constituídos materialmente}

Destacando os elementos materialistas de sua teoria, Pêcheux (2009a) nos apresenta o esboço de uma teoria não-subjetivista da subjetividade, a qual delineia processos de imposição/dissimulação que constituem o sujeito ao mesmo tempo em que dissimulam o assujeitamento. Nesse movimento de imposição/dissimulação, o fundador da Análise do Discurso estabelece a relação entre inconsciente, no sentido freudiano, e ideologia, no sentido marxista. Para fundamentar sua teoria e explicar a relação entre inconsciente e ideologia, retoma a afirmação de Thomas Herbert (seu pseudônimo) de que a ideologia interpela os indivíduos em sujeitos, a qual se ampara na obra "Aparelhos Ideológicos de Estado" de Althusser (1996), mais especificamente na afirmação de que “"[...] o indivíduo é interpelado como sujeito [livre] para livremente submeter-se às ordens do Sujeito, para aceitar, portanto [livremente] sua submissão..."” (p.124). Retoma também Lacan e afirma que 
formulação de Lacan, 'o inconsciente é o discurso do Outro', podemos discernir de que modo o recalque inconsciente e o assujeitamento ideológico estão materialmente ligados, sem estar confundidos, no interior do que se poderia designar como o processo do Significante na interpelação e na identificação, processo pelo qual se realiza o que chamamos as condições ideológicas da reprodução/transformação das relações de produção." (Pêcheux, 2009a, p. 124-125).

Observando o caráter comum dessas duas estruturas-funcionamento, quais sejam o assujeitamento ideológico e o recalque inconsciente, o fundador da Análise do Discurso afirma que a função delas é "[...] dissimular sua própria existência no interior mesmo do funcionamento, produzindo um tecido de evidencias 'subjetivas', devendo entender-se esse último adjetivo não como 'que afetam o sujeito', mas 'nas quais se constitui o sujeito' [...]” (Pêcheux, 2009a, p. 139). Em outras palavras, o sujeito, no processo de interpelação é atravessado pelo recalque inconsciente e pela ideologia, ao passo que no processo de identificação são produzidas evidências que criam um efeito de apagamento da interpelação. A partir da constituição do sujeito, o autor se movimenta a pensar a constituição dos sentidos, como evidência, pela evidência do sujeito, via interpelação-identificação. Sob a evidência, os sujeitos se constituem, por exemplo, na pós-modernidade, embebidos em sentidos que naturalizam a relação de proximidade entre o corpo e os objetos tecnológicos de conexão à rede eletrônica, de tal modo que a discrepância de um cabo de rede pictograficamente conectado na veia de um sujeito, provoca o estranhamento de poucos olhares, e a naturalização de sentidos como "vício" na rede. Assim, da Figura 1, pinçada de um site que ilustra a relação de dependência em relação a tecnologia, pudemos recortar esse efeito de naturalização, no qual um cabo de rede normalmente conectado a um objeto tecnológico, é, no entanto, conectado na veia de um corpo, dispensando a interface maquínica, acoplando-se diretamente no corpo, introduzindo nele uma prótese tecnológica que não lhe é própria, ligando o corpo à rede eletrônica. 


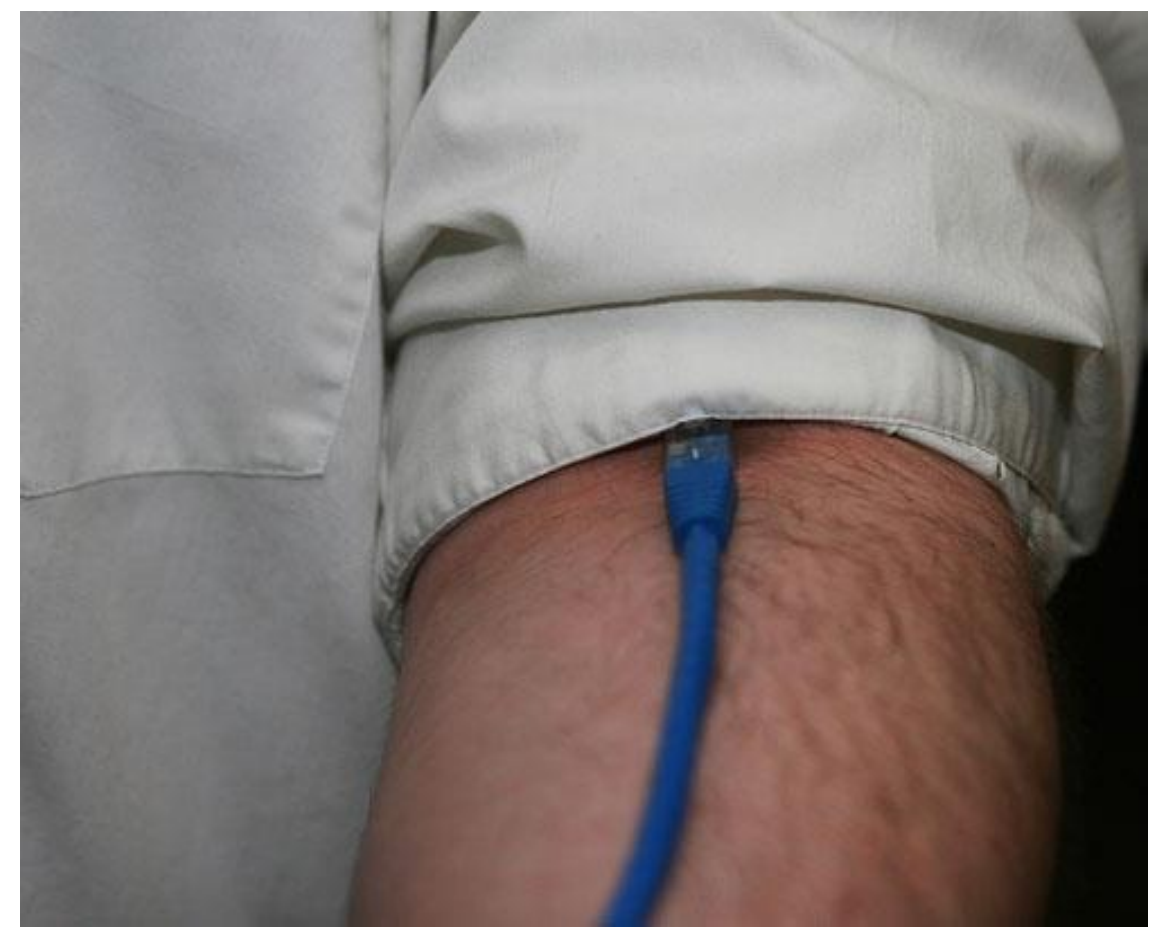

Figura $1^{5}$

Prosseguindo nas questões das evidências, apoiado em Althusser, Pêcheux (2009a) considera que a interpelação do sujeito pela ideologia perpassa o vínculo determinado pela infra-estrutura econômica entre o aparelho repressivo de Estado, que controla as identidades, e os aparelhos ideológicos de Estado, que caracterizam o vínculo entre o sujeito de direito (aquele que entra em contrato com outros) e o sujeito ideológico (aquele que diz "Sou eu”). "[...] Seu mérito é também o de mostrar esse vínculo de uma maneira tal que o teatro da consciência (eu vejo, eu penso, eu falo, eu te vejo, eu te falo etc.) é observado dos bastidores, lá de onde se pode captar que se fala do sujeito, que se fala ao sujeito, antes de que o sujeito possa dizer: 'Eu falo'[...]" (p. 140).

Segundo Pêcheux (2009a), a tese de que a Ideologia interpela os indivíduos em sujeitos traz um paradoxo, posto que o não-sujeito (indivíduo) é interpelado em sujeito pela Ideologia, ao mesmo tempo em que o efeito retroativo faz com que todo indivíduo seja sempre já-sujeito, e acrescenta que a evidência do sujeito como idêntico a si mesmo (quando diz "Sou eu") oculta o estranho-familiar, oculta que o indivíduo é interpelado em sujeito, sendo sempre já-sujeito. A mistura de absurdo e de evidência, o retorno do estranho no familiar, são apontados por Pêcheux na noção de pré-construído, um efeito que consiste numa discrepância em que um elemento irrompe num enunciado como se ele tivesse sido pensado antes, em outro lugar.

\footnotetext{
${ }^{5}$ Recuperado em 31 de outubro de 2013, de http://www.vicioweb.com.br/inicio/?tag=internet
} 
Podemos, de agora em diante, tendo em conta o que acabamos de expor, considerar o efeito de pré-construído como a modalidade discursiva da discrepância pela qual o indivíduo é interpelado em sujeito ... ao mesmo tempo em que é 'sempre-já sujeito', destacando que essa discrepância (entre a estranheza familiar desse fora situado antes, em outro lugar, independentemente, $e$ o sujeito identificável, responsável, que dá conta de seus atos) funciona 'por contradição', quer o sujeito, em toda sua ignorância, se submeta a ela, quer, ao contrário, ele a apreenda por meio de sua agudeza de 'espírito': um grande número de brincadeiras, anedotas etc., são, de fato, regidas pela contradição inerente a essa discrepância; elas constituem como que sintomas dessa apreensão e tem como sustentáculo o círculo que liga a contradição sofrida (isto é, a 'estupidez') à contradição apreendida e exibida (isto é, a 'ironia') [...] (Pêcheux, 2009a, p. 142).

Em associações com a psicanálise, o fundador aponta que no papel de sintoma, no qual reconhece o funcionamento de brincadeiras que levam em conta a identidade do sujeito ou de um acontecimento, está a existência de "[...] um processo do significante, na interpelaçãoidentificação. [...]” (p. 143) e localiza isso na obra lacaniana ao afirmar que o significante representa o sujeito para um outro significante, estando aí a questão do sujeito como processo, como advindo da rede de significantes, como causa de si, no sentido espinosano. Assinala que a existência dessa contradição, ou seja, produzir o resultado de uma causa de si, e a relação do significante na interpelação-identificação, “[...] nos autorizam a dizer que se trata realmente de um processo, na medida em que os 'objetos' que nele se manifestam se desdobram, se dividem, para atuar sobre si enquanto outro de si." (p. 143).

O apagamento do fato de que o sujeito resulta de um processo de apagamento necessário no interior do sujeito como 'causa de si', tem como consequência, a nosso ver, a série do que se poderia chamar as fantasias metafísicas, que tocam, todas, na questão da causa: por exemplo, a fantasia das duas mãos que, tendo cada uma um lápis, se desenham uma à outra sobre a mesma folha de papel e, também, a do salto perpétuo no qual, de um impulso prodigioso, se salta pro alto antes de se ter tocado o solo; poderíamos continuar. Vamos nos deter, propondo atribuir a esse efeito fantástico - pelo qual o indivíduo é interpelado em sujeito - o nome de "efeito Münchhausen", em memória do imortal barão que se elevava nos ares puxando-se pelos próprios cabelos." (Pêcheux, 2009a, p. 144).

Assim, o pensador do campo discursivo diz que, sob a evidência de que "eu sou eu", há o processo de interpelação-identificação que produz o sujeito, sob a forma do sujeito de direito e do sujeito ideológico. Ou seja, a evidência funciona apagando o processo de imposição/assujeitamento, e, consequentemente, tentando apagar a não obviedade de que "eu sou eu", como fonte e origem de si. A partir do ancoramento de Pêcheux em Freud, podemos 
trazer o texto "Uma nota sobre o bloco mágico" (1925[1924]/1996j), para apontarmos que o termo "apagar" não se refere a uma não existência, posto que o apagamento deixa marcas na matéria, havendo apenas um semblante de inexistência, um mascaramento.

De acordo com Orlandi (2007a, p. 18), a grande contribuição da Análise do Discurso ao conceber o processo de interpelação-identificação, imposição-assujeitamento foi “[...] observar os modos de construção do imaginário necessário na produção dos sentidos. [...]” pois, como ela aponta, há a necessidade da construção do um na relação com o múltiplo. Há a necessidade da construção do sujeito, do sentido na relação com a multiplicidade de sentidos. Há a necessidade da contrução do "Eu sou" enquanto evidência para a própria existência da diferença. A autora se apóia em Pêcheux (2009a) para dizer que a forma unitária é o meio para a divisão e a contradição, pois a diferença precisa da construção imaginária da unidade (do sentido). De acordo com Orlandi (2007a, p. 19), “[...] essa ilusão de unidade é efeito ideológico, é construção necessária do imaginário discursivo. Logo, tanto a dispersão como a ilusão da unidade são igualmente constitutivas."6

Pêcheux (2009a, p. 146) afirma que a ideologia é o que determina "o que é e o que deve ser", fornecendo as “[...] evidências que fazem com que uma palavra ou um enunciado 'queiram dizer o que realmente dizem' e que mascaram, assim, sob a ‘transparência da linguagem' aquilo que chamaremos o caráter material do sentido das palavras e dos enunciados.". A ideologia, portanto, é entendida "não como ocultação mas como produtora de evidências" (Orlandi, 2012d, p. 213). Conforme Orlandi (2007a), a ideologia se produz no encontro da língua com a história, sendo o discurso o lugar em que esse encontro se materializa. Mais especificamente, de acordo com o fundador, a ideologia se materializa nas formações ideológicas, o que condiciona que a significação de uma palavra é determinada pelas posições ideológicas no processo sócio-histórico. Assim, as palavras mudam de sentido de acordo com aqueles que as empregam.

As formações ideológicas, que materializam a ideologia, atravessam as formações discursivas, determinando o que pode e deve ser dito em dada condição de produção, e, desse modo, “[...] os indivíduos são 'interpelados' em sujeitos-falantes (em sujeitos de seu discurso) pelas formações discursivas que representam 'na linguagem' as formações ideológicas que lhes são correspondentes.” (p. 147). Em “A semântica e o corte saussuriano: língua, linguagem,

\footnotetext{
${ }^{6}$ Podemos associar este apontamento de Orlandi (2007a) ao que Lacan (1998c) afirma com o estádio do espelho. Se tanto a dispersão quanto a ilusão de unidade são constitutivas do sujeito, para a Análise do Discurso, veremos no capítulo 3 como o eu se constitui na relação especular a partir da concepção de um corpo despedaçado para uma imagem totalizante do corpo.
} 
discurso", Pêcheux, Haroche e Henry (2007, p. 20) apontam que as formações ideológicas comportam uma ou várias formações discursivas e determinam o que pode e deve ser dito a partir de uma dada conjuntura, “[...] o ponto essencial aqui é que não se trata apenas da natureza das palavras empregadas, mas também (e sobretudo) de construções nas quais essas palavras se combinam, na medida em que elas determinam a significação que tomam essas palavras [...]".

Importa ainda lembrar que o limite de uma formação discursiva é o que a distingue de outra (logo, é o mesmo limite da outra), o que permite pensar (como Courtine, 1982) que a formação discursiva é heterogênea em relação a ela mesma, pois já evoca por si o "outro" sentido que ela não significa. Ora, a relação com as múltiplas formações discursivas nos mostra que não há coincidência entre a ordem dos discursos e a ordem das coisas. Uma mesma coisa pode ter diferentes sentidos para os sujeitos. E é aí que se manifestam a relação contraditória da materialidade da língua e a da história. (Orlandi, 2007a, p. 21).

Retomando a relação que faz entre base - linguística -, e processo - discursivo e ideológico -, o pensador francês explica que:

[...] se uma mesma palavra, uma mesma expressão e uma mesma proposição podem receber sentidos diferentes - todos igualmente 'evidentes' - conforme se refiram a esta ou aquela formação discursiva, é porque - vamos repetir uma palavra, uma expressão ou uma proposição não tem um sentido que the seria 'próprio', vinculado a sua literalidade. Ao contrário, seu sentido se constitui em cada formação discursiva, nas relações que tais palavras, expressões ou proposições mantêm com outras palavras, expressões ou proposições da mesma formação discursiva. De modo correlato, se se admite que as mesmas palavras, expressões e proposições mudam de sentido ao passar de uma formação discursiva a uma outra, é necessário também admitir que palavras, expressões e proposições literalmente diferentes podem, no interior de uma formação discursiva dada, 'ter o mesmo sentido', o que - se estamos sendo bem compreendidos - representa, na verdade, a condição para que cada elemento (palavra, expressão ou proposição) seja dotado de sentido. A partir de então, a expressão processo discursivo passará a designar o sistema de relações de substituição, paráfrases, sinonímias etc., que funcionam entre elementos linguísticos - 'significantes' - em uma formação discursiva dada. (Pêcheux, 2009a, p. 147-148).

Portanto, pela transparência do sentido que toda formação discursiva dissimula, se dá a sua dependência ao "todo complexo com dominante" das formações discursivas, as quais estão imbricadas no complexo das formações ideológicas. Ao "todo complexo com dominante" das formações discursivas, Pêcheux (2009a, p. 149) nomeia interdiscurso. Assim, segundo o autor, toda formação discursiva dissimula, sob o efeito de transparência do sentido, o interdiscurso, que determina dada formação discursiva, disfarçando que “[...] 'algo fala' (ça parle) sempre 
'antes, em outro lugar e independentemente', isto é, sob a dominação do complexo das formações ideológicas [...]”.

As diferentes formulações de enunciados se reúnem em pontos do dizer, em
regiões historicamente determinadas de relações de força e de sentidos: as
formações discursivas. Expliquemo-nos. Para Pêcheux, o discurso é efeito de
sentidos entre locutores. Compreender o que é efeito de sentidos é
compreender que o sentido não está (alocado) em lugar nenhum mas se produz
nas relações: dos sujeitos, dos sentidos, e isso só é possível, já que sujeito e
sentido se constituem mutuamente, pela sua inscrição no jogo das múltiplas
formações discursivas (que constituem as distintas regiões do dizível para os
sujeitos). As formações discursivas são diferentes regiões que recortam o
interdiscurso (o dizível, a memória do dizer) e que refletem as diferenças
ideológicas, o modo como as posições dos sujeitos, seus lugares sociais aí
representados, constituem sentidos diferentes. O dizível (interdiscurso) se
parte em diferentes regiões (as diferentes formações discursivas)
desigualmente acessíveis aos diferentes locutores. [...] (Orlandi, 2007a, p. 20-
21).

Além do interdiscurso, Pêcheux (2009a), nos aponta o intradiscurso, que é entendido como o funcionamento do discurso com relação a si mesmo, ou seja, aquilo que é dito em relação ao que é dito a seguir. No jogo do interdiscurso e o intradiscurso, o efeito de transparência do sentido é constituído pelo efeito do que Pêcheux denomina "esquecimentos". Apoiado na primeira tópica freudiana do sistema pré-consciente, consciente e inconsciente, o fundador da Análise do Discurso estabelece que o esquecimento ao qual nomeia como "número 2" é o processo pelo qual o sujeito-falante "seleciona" um enunciado e não outro na formação discursiva que o domina, para enunciar o que acredita ser o mesmo, como se as palavras fossem coladas ao significado. Esse esquecimento, segundo ele, situa-se no âmbito pré-consciente. Já o "esquecimento número 1" se dá pelo fato do sujeito-falante não poder se encontrar no exterior da formação discursiva que o domina, ou seja, o efeito do esquecimento $\mathrm{n}^{\circ} 1$ faz o sujeitofalante acreditar que as palavras nele brotam enquanto que as palavras a ele preexistem, não havendo escapatória à interpelação, mesmo na resistência.

Sob os esquecimentos, então, no interior da formação discursiva que o domina, o sujeito acredita que usar uma palavra ou outra equivale ao mesmo e acredita que é a origem dos sentidos. Usar uma palavra e não outra, circular um sentido e não outro, nos faz pensar com Orlandi (2008) - que se apóia em Courtine (1981) - na enunciação como duas retas perpendiculares que se cruzam, sendo o eixo vertical, o interdiscurso, o eixo da constituição dos sentidos e o eixo horizontal, o intradiscurso, o eixo da formulação dos sentidos. Segundo a 
autora, o esquecimento número 1 incide no eixo do interdiscurso e o número 2 no eixo do intradiscurso.

Pêcheux (2009a) aponta que o discurso é marcado por uma tensão permanente entre o interdiscurso e o intradiscurso e delineia que o funcionamento da Ideologia em geral como interpelação dos indivíduos em sujeitos (de seu discurso) se realiza pelo complexo das formações ideológicas (e do interdiscurso), fornecendo a cada sujeito uma realidade enquanto sistema de evidências. Sistema de evidências que atravessam os sujeitos em suas posições discursivas. Ao dizer que o ego, o imaginário do sujeito não pode reconhecer seu assujeitamento ao Outro ou ao Sujeito, já que essa "subordinação-assujeitamento" se realiza sob a forma de autonomia ("Eu sou"), ele retoma o efeito sujeito como interior sem exterior. De acordo com Pêcheux (2009a), a "subordinação-assujeitamento" que se realiza sob a forma da autonomia, fisga o sujeito do discurso na forma-sujeito, pela via da identificação a uma ou mais formações discursivas dominantes, que, sob o efeito dos esquecimentos, fundam a unidade imaginária do sujeito. Vejamos:

Somos assim levados a examinar as propriedades discursivas da forma-
sujeito, do 'Ego-imaginário', como ‘sujeito do discurso'. Já observamos que
o sujeito se constitui pelo 'esquecimento' daquilo que o determina. Podemos
agora precisar que a interpelação do indivíduo em sujeito de seu discurso se
efetua pela identificação (do sujeito) com a formação discursiva que o domina
(isto é, na qual ele é constituído como sujeito): essa identificação, fundadora
da unidade (imaginária) do sujeito, apóia-se no fato de que os elementos do
interdiscurso (sob sua dupla forma, [...] enquanto pré-construído' e 'processo
de sustentação') que, constituem, no discurso do sujeito, os traços daquilo que
o determina, são re-inscritos no discurso do próprio sujeito. (Pêcheux, 2009a,
p. 150).

O fundador da Análise do Discurso se ampara nessas colocações para elaborar seu conceito de forma-sujeito, afirmando que a identificação com a formação discursiva dominante produz a forma-sujeito ao impor a realidade ao sujeito sob a forma do desconhecimento, "“...] forma da qual a ficção [...] representa a modalidade mais 'pura' [...]" (p. 158), e em função desse desconhecimento, é fundado um reconhecimento, caracterizado pelo que Althusser nomeia como o reconhecimento entre o sujeito e o Sujeito, entre os próprios sujeitos e o reconhecimento de cada sujeito por si próprio. "É nesse reconhecimento que o sujeito se 'esquece' das determinações que o colocaram no lugar que ele ocupa [...]”' (p. 158). Portanto, o efeito da forma-sujeito do discurso é mascarar o objeto do esquecimento $\mathrm{n}^{\mathrm{o}} 1$, pelo funcionamento do esquecimento $\mathrm{n}^{\circ}$ 2. “[...] Assim, o espaço de reformulação-paráfrase que caracteriza uma formação discursiva dada aparece como o lugar de constituição do que 
chamamos o imaginário linguístico (corpo verbal)" (p. 165). Para Orlandi (2007a), a relação entre os processos discursivos e a língua sustentam a compreensão do imaginário como necessário. Acrescenta que os processos discursivos se sustentam na base fornecida pela estrutura da língua e não são meramente a expressão de uma atividade cognitiva que utilizaria por acaso os sistemas linguísticos. Os discursos advindos dos processos discursivos são duplamente determinados, de um lado, pelas formações ideológicas e de outro pela autonomia relativa da língua.

O fundador apresenta as modalidades da forma-sujeito, discutindo a relação do sujeito da enunciação com o sujeito universal, de forma a articular as possíveis "tomadas de posição" do sujeito no assujeitamento. Afirma, então, três modalidades, quais sejam: 1) A modalidade da identificação, na qual há uma superposição do sujeito universal no sujeito da enunciação, ou melhor, “[...] o interdiscurso determina a formação discursiva com a qual o sujeito, em seu discurso, se identifica, sendo que o sujeito sofre cegamente essa determinação, isto é, ele realiza seus efeitos em "plena liberdade"” (Pêcheux, 2009a, p. 199). 2) A modalidade da contraidentificação, na qual o sujeito da enunciação se separa do sujeito universal, questionado-o, ou seja, “[...] o sujeito [...] se contra-identifica com a formação discursiva que lhe é imposta pelo ‘interdiscurso' [...]” (Pêcheux, 2009a, p. 199-200). 3) A modalidade da desidentificação, a qual é uma tomada de posição não-subjetiva que inclui “[...] um trabalho (transformaçãodeslocamento) da forma-sujeito e não sua pura e simples anulação [...]" (Pêcheux, 2009a, p. 202). Essa terceira se diferencia das duas anteriores na medida em que as modalidades da identificação e da contra-identificação são reguladas pela identificação à formação discursiva dominante que regula a evidência do sentido, ainda que a tomada de posição seja de aceitação ou de rejeição. Pêcheux (2009a) aponta que, ainda que assujeitado, “[...] todo sujeito é assujeitado no universal como singular 'insubstituível'[...]” (p. 159).

Passemos à algumas retificações de Pêcheux (2009b). Em 1978, três anos após a publicação de "Semântica e Discurso", nove anos após a publicação de “Análise Automática do Discurso", o fundador se lança a pensar sobre o "fogo incinerador" que permeava as discussões levantadas acerca do entrelaçamento do que chamou como "Tríplice Aliança".

Intervir no Marxismo sobre a questão da ideologia, levantando questões sobre sua relação com a Psicanálise e com a Linguística, é ipso facto, mexer com uma espécie de 'Tríplice Aliança' teórica que, na França ao menos, se configurou sob os nomes de Althusser, Lacan e Saussure no decorrer dos anos 60. Como se sabe, o destino dessa Tríplice Aliança é, hoje mais do que nunca, extremamente problemático, e até mesmo as partes do pacto são objeto de um 
verdadeiro bate-boca teórico $e$ político em que tudo se abre novamente a questionamentos. (Pêcheux, 2009b, p. 269).

Pêcheux (2009b, p. 271) tece gestos de interpretação a suas próprias produções e é assim que ele retoma "Semântica e discurso" escutando um ruído de non sens que evocava sua posição em relação a forma-sujeito e as interlocuções entre o materialismo histórico e a psicanálise. Para seu re-posicionamento, traz a seguinte formulação resumida contida na conclusão do texto de 1975: “[...] 'A forma-sujeito do discurso, na qual coexistem, indissociavelmente, interpelação, identificação e produção de sentido, realiza o non sens da produção do sujeito como causa de si sob a forma da evidência primeira"' Pêcheux (2009b, p. 275) aponta que essa tese produz um estranho ruído porque trata do ponto-limite da reflexão marxista, "a ideologia interpela o indivíduo em sujeito", tocando o impossível de uma forma-sujeito tomada na História como processo sem Sujeito nem Fim. A partir dessa constatação, afirma, então, que, apesar de suas precauções teóricas, delineou “[...] um paradoxal sujeito da prática política do proletariado cuja simetria tendencial com o sujeito da prática política burguesa não era questionada!”. Tal paradoxo contornava: o mecanismo da interpelação-assujeitamento; o esquecimento de qualquer traço desse mecanismo no sujeito pleno dele produzido; seu apagamento resultava em uma noção de "apropriação subjetiva".

Para ele, outra dificuldade em "Semântica e Discurso" se refere ao que foi dito sobre o ego e o sujeito, na intersecção com a psicanálise.

[...] Tudo se passa [...] como se o que foi dito do sujeito se confundisse tendencialmente com o que foi posto relativamente ao ego como 'formasujeito' da ideologia jurídica, a ponto de que o funcionalismo, expulso politicamente pela porta, pudesse, apesar de todas as denegações, ter voltado a tamborilar pela janela psicanalítica, sob a forma de uma espécie de gênese do ego; à força de levar exageradamente a sério as ilusões do poder unificador da consciência." (Pêcheux, 2009b, p. 276).

O fundador, então, chega à conclusão que levar muito a sério a ilusão de um ego-sujeitopleno em que nada falha é o que falha em "Semântica e Discurso", e tal ilusão é o próprio engodo que ele aponta em sua teoria, em seu movimento de fazer frente à completude. Apoiando-se no aforismo lacaniano "Só há causa daquilo que falha", Pêcheux (2009b, p. 277) pontua que a causa é justamente aquilo que falta, "[...] a causa que determina o sujeito exatamente onde o efeito de interpelação o captura [...]”; causa que se manifesta no ato falho, nos sonhos, nos lapsos, nos chistes, “[...] pois os traços inconscientes do significante não são jamais 'apagados' ou 'esquecidos', mas trabalham, sem se deslocar, na pulsação sentido/non- 
sens do sujeito dividido". Em relação à questão do "apagamento", trouxemos anteriormente a citação do texto freudiano "Nota sobre o bloco mágico", no qual o fundador da psicanálise aponta que as marcas permanecem no inconsciente, sendo, como agora afirma Pêcheux, jamais esquecidos ou apagados. Pêcheux (2009b) assinala que esse reposicionamento faz separar o conceito de recalque do conceito de esquecimento ou apagamento.

Nesse momento de sua teorização, o fundador afirma que o sentido é produzido no nonsens, e que o deslizamento metafórico não desaparece sem deixar marcas no sujeito-ego da 'forma-sujeito ideológica' que se identifica à evidência de um sentido. Para Pêcheux (2009b, p. 278), apreender a interpelação ideológica como um ritual, pressupõe o reconhecimento de que não há ritual sem falhas, e lança-se a questão: "Por esse viés, não estaria a série analítica sonho-lapso-ato falho-Witz encontrando obliquamente aqui algo que infecta constantemente a ideologia dominante, do próprio interior das práticas em que ela tende a se realizar? [...]”. O lapso e o ato falho, como falhas do ritual, conforme o fundador, podem ter a ver com a resistência e com a revolta, "[...] formas de aparição fugidias de alguma coisa 'de uma outra ordem', vitórias ínfimas que, no tempo de um relâmpago, colocam em xeque a ideologia dominante tirando partido de seu desequilíbrio”. A partir dessas retomadas da interlocução da Análise do Discurso com o Materialismo Histórico e com a Psicanálise, Pêcheux (2009b, p. 278-279) alerta que:

Retraçar a vitória do lapso e do ato 'falho' nas falhas da interpelação ideológica não supõe que se faça agora do inconsciente a fonte da ideologia dominada, depois do fracasso de fazê-lo o impulso do superego da ideologia dominante: a ordem do inconsciente não coincide com a da ideologia, o recalque não se identifica nem com o assujeitamento nem com a repressão, mas isso não significa que a ideologia deva ser pensada sem referência ao registro inconsciente $[\ldots]$.

Prossegue apontando que se dá conta de que por meio de um excessivo uso de chistes em "Semântica e Discurso", como um sintoma, tentou manter o non-sens, posto que "[...] uma descoberta tem fundamentalmente a ver com o desequilíbrio de uma certeza. [...]” (p. 280). O chiste desequilibrava sua certeza, pelo non-sens. Por sua trajetória de escrita, de formulação teórico-prática, o fundador aponta que o atravessamento de chistes em sua escrita, “[...] reforça que o pensamento é fundamentalmente inconsciente ('isso [ça] pensa!') [...] o Witz representa um dos pontos visíveis em que o pensamento teórico encontra o inconsciente: o Witz apreende algo desse encontro, dando a aparência de domesticar seus efeitos” (p. 280). 
Isso nos faz pensar que, embora Pêcheux aponte deslizes, quiçá na domesticação de alguns sentidos sobre os conceitos elaborados, capturado pela unidade imaginária conceitual (tão demandada nas ciências), o método de trabalho que ele fundou não é domesticado, nem domesticável, tanto que propicia gestos de interpretação à própria teorização e análise, na medida em que Pêcheux (2009b, p. 271) se depara com dois pontos incontornáveis, já inerentes à Análise do Discurso, e ao sujeito:

- não há dominação sem resistência: primado prático da luta de classes, que significa que é preciso 'ousar se revoltar'.

-ninguém pode pensar do lugar de quem quer que seja: primado prático do inconsciente, que significa que é preciso suportar o que venha a ser pensado, isto é, é preciso 'ousar pensar por si mesmo'.

As retificações apontam o quanto o fundador se deixa atravessar pela ideia de processo, já que no exercício constante de demarcar o campo da Análise do Discurso e as interlocuções com os campos que a constituíram e, sobretudo, as marcas de diferenciação com estes campos, ele faz pulsar em sua prória teoria a luta com a língua, a história e o inconsciente, escutando incessantemente o processo de produção do conhecimento no seu próprio campo, o que aponta que o gesto de interpretação se dá na relação do analista de discurso com a teoria e a análise.

A ideia de processo, então, ao mesmo tempo em que constitui sujeito e discurso, sendo por estes constituído, também constitui o gesto de interpretação que Pêcheux inaugura e por ele é constituído, um gesto que busca um se deslocar do "efeito Münchhausen". Assim, a teoria pecheuxteana é uma teoria crítica que se engaja a pensar o discurso, o sujeito e o processo de interpelação-assujeitamento. Seguiremos trazendo mais gestos de interpretação de Pêcheux ao conceito de discurso, introduzindo para além da estrutura, o acontecimento, o fato novo, aquilo que vem mover sentidos anteriormente estabilizados, e que, se reafirma a noção de que as palavras, expressões, proposições mudam de sentido ao passar de uma formação discursiva para outra, vai além, apresentando a noção de acontecimento discursivo somada a uma atualidade e a uma memória. 
1.3.1 O discurso, estrutura e acontecimento: no ponto de encontro de uma atualidade e uma memória

Pêcheux (2008), na década de 80, faz avançar a concepção de discurso como efeito de sentido entre locutores propondo-o "[...] como estrutura e como acontecimento [...]" (p. 16) e localiza o que chama de "acontecimento" "no ponto de encontro de uma atualidade e uma memória [...]" (p. 17). Aponta o “[...] o acontecimento (o fato novo, as cifras, as primeiras declarações) em seu contexto de atualidade e no espaço de memória que ele convoca e que já começa a reorganizar [...]” (p. 19). Nesse momento, então, além do fundador da Análise do Dsicurso apontar que os processos discursivos são diferenciados, ainda que a língua seja a base, propõe pensar que os enunciados - que podemos chamar de processos discursivos - podem se constituir como acontecimento, na medida em que reorganizam uma memória num campo de atualidade. Trabalha com o enunciado "On a gagné" que emerge em 10 de maio de 1981 nas comemorações da vitória de François Mitterrand à presidência da França e o aponta como um acontecimento na medida em que reorganiza uma memória, na atualidade, já que "On a gagné" é tradicionalmente o grito das torcidas de futebol. Traça os meandros discursivos no qual um grito das torcidas de futebol, uma memória avivada em certas condições de produção, se desloca e passa a significar a vitória no campo político, mais especificamente uma vitória do Partido Comunista na França. Podemos dizer, então, que um acontecimento se dá na reorganização de uma memória e que ele não é a mera reprodução de uma memória, já que ele convoca os sujeitos à filiação a uma outra formação discursiva, embora o sentido de vitória seja preservado.

Em "Papel da Memória”, Pêcheux (1999) prossegue as discussões sobre acontecimento e memória e indica que "[...] todo discurso marca a possibilidade de uma desestruturaçãoreestruturação [...]" das redes e trajetos de memória. Sobre a memória, aponta que esse conceito deve ser entendido “[...] nos sentidos entrecruzados da memória mítica, da memória social inscrita em práticas, e da memória construída do historiador [...]” (p. 50) e não na memória psicologista, individual. Encontramos o pensador francês ressaltando "as nervuras principais do debate" realizado por Pierre Achard, Jean Davallon e Jean-Louis Durand sobre o papel da memória, onde ele destaca que as questões colocadas conduziram a abordagem das " [...] condições (mecanismos, processos...) nas quais um acontecimento histórico (um elemento histórico descontínuo e exterior) é suscetível de vir a se inscrever na continuidade interna, no espaço potencial de coerência próprio a uma memória” (Pêcheux, 1999, p. 49-50). 
Destaca a memória como estruturante da materialidade discursiva em uma dialética da repetição e da regularização. Segundo ele, “[...] a memória discursiva seria aquilo que, face a um texto que surge como acontecimento a ler, vem restabelecer os 'implícitos' [...] a condição do legível em relação ao próprio legível [...]” (p. 52). Apoiado em Achard (1999), afirma que sob a repetição haveria um efeito de série, uma 'regularização', sempre sujeita ao acontecimento discursivo que perturba a memória, desregulando a série, o qual, todavia, é absorvido pela memória, mas pode provocar uma nova série a partir daquela, como produto do acontecimento.

Assim, Pêcheux (1999, p. 52) destaca que "[...] o acontecimento, no caso, desloca e desregula os implícitos associados ao sistema de regularização anterior”. Sob o acontecimento, há um jogo de força na memória que visa manter a regularização anterior, estabilizando o acontecimento até absorvê-lo e dissolvê-lo em outro jogo de força que visa a desregulação, perturbando os implícitos. Define que “[...] a repetição é antes de tudo um efeito material que funda comutações e variações, e assegura - sobretudo ao nível da frase escrita - o espaço de estabilidade de uma vulgata parafrástica produzida por recorrência, quer dizer, por repetição literal dessa identidade material” (p. 53). Mas, salienta, apoiado em Marandin (1999), que a recorrência do enunciado pode dividir sua identidade material e sob o mesmo repetitório, pode abrir o jogo da metáfora, uma repetição vertical, na qual a memória se esburaca, antes de se desdobrar em paráfrase. A partir do debate, conclui que a memória é “[...] um espaço móvel de divisões, de disjunções, de deslocamentos e de retomadas, de conflitos de regularização... Um espaço de desdobramentos, réplicas, polêmicas e contra-discursos” (p. 56). E que, portanto, “[...] nenhuma memória pode ser um frasco sem exterior” (p. 56), pois abarca o real histórico.

Pensando na questão da memória, podemos tomar a obra pecheuxteana como uma memória que constitui a produção dos/de analistas de discurso. É isso o que ele nos deixa, uma memória que não é um frasco sem exterior, pois os conceitos por ele articulados não cessaram de produzir efeitos, sentidos, sentidos no sentido também de direção, deixando que o acontecimento também permeasse a disciplina de interpretação, que hoje produz outros conceitos. Após Pêcheux, mas não sem ele. Se o discurso é efeito de sentidos entre locutores, se pode se constituir em estrutura e acontecimento, Orlandi (2007a) tece o real do discurso, o silêncio. 


\subsubsection{O real do discurso}

Se a noção de "efeitos de sentido" levou um tempo para ser articulada no campo das ciências linguísticas, ela não passou despercebida aos ouvidos de Pêcheux em um contexto sócio-histórico no qual o sentido dominante era (e ainda é) o de um fechamento do sentido apesar dos movimentos de resistência da década de sessenta já apontarem para o jogo de forças nos sentidos e nas relações sociais -, a noção de silêncio levou mais algum tempo para ser concebida, já que, se nem as palavras poderiam transpirar, que dirá o silêncio, tomado até então como ausência de som, de palavras. Dessa vez, são os ouvidos de Orlandi (2007a) que se abrem à escuta ao silêncio inerente às palavras e ao silenciamento de sentidos, tanto o constitutivo quanto a censura.

Seus ouvidos apontam o que foi possível escutar após alguns anos da ditadura no Brasil, uma época marcada pela extrema contenção de sentidos, ou seja, pelo silenciamento, e, por outro lado, por um transbordamento do silêncio inerente aos poros das palavras, que transpirava efeitos em metáforas e metonímias para dizer da censura. Uma cesura possível: "Você não gosta de mim, mas sua filha gosta", cantava Chico Buarque. É assim que essa formulação discursiva desliza de um contexto que evoca um jogo de forças entre um enamorado e o pai da mulher amada para um contexto que evoca um jogo de forças no campo político. Queremos dizer, assim, que, aquilo que é silenciado de uma maneira, pelo próprio silêncio, nos poros das palavras e nos efeitos de sentido, emerge em uma outra formulação discursiva autorizada a circular.

Orlandi (2007a), articulando a premissa pecheuxteana de que a língua, em sua materialidade, é a base comum de todos os processos discursivos, ou seja, é o pré-requisito para se pensar os processos discursivos, vai delineando o conceito de "silêncio", e, para localizá-lo, aponta a separação entre a ordem das coisas e a ordem do discurso, separação que marca um descolamento/deslocamento do discurso da coisa em si, do campo da palavra do campo do objeto, pois um significante pode ter vários significados e, por outro lado, pode evocar o non sense como o extremo oposto do sentido. Como já vimos com Pêcheux (2009a), nos efeitos de colamento da palavra ao significado está a ideologia para fazer naturalizar certos sentidos, estão os esquecimentos.

Orlandi (2007a, p. 27) pontua que por meio da noção de "efeito de sentidos" tem-se que o sentido não está alocado, não é fixo, e se produz nas relações. É na abertura do "efeito de 
sentidos" que a autora aponta o trabalho do silêncio, já que, “[...] a linguagem estabiliza o movimento dos sentidos. No silêncio, ao contrário, sentido e sujeito se movem largamente". Assim, o silêncio não fala, ele não é somente ausência de som, ele é, significa. Dele o que se tem são pistas, são traços deixados e não marcas formais. O silêncio tem primazia sobre as palavras e a linguagem é categorização do silêncio, ela contorna o desejo de unicidade do homem em sua relação com o simbólico sobre o domínio verbal. Como o silêncio é múltiplo, a linguagem visa o "um", algum sentido.

No jogo da linguagem com o silêncio e do silêncio com a linguagem, dá-se a incompletude (da língua, do discurso, do sujeito), na medida em que há um jogo entre o múltiplo e o um, o múltiplo aponta para a possibilidade da polissemia, e o um, trabalha com um fechamento, que não é hermético, já que o “um”, pelo efeito imaginário, evoca também o seu oposto, o diferente. Tecendo algumas entradas do conceito de silêncio na teoria alicerçada por Pêcheux, Orlandi (2007a) pontua que a não-completude inerente aos processos discursivos, assim se estabelece: a) na constituição do sujeito, o silêncio rompe com a absolutização narcísica do eu, que seria a asfixia do sujeito, fazendo, assim, ao nosso ver oposição ao "um" e abrindo à polissemia. Sendo o apagamento da interpelação necessário para a constituição do sujeito, o silenciamento faz parte da constituição do processo identificatório, confome a autora. b) na constituição do sentido, o silêncio nas palavras barra o muito cheio (de polissemia ou de fechamento de sentido), a possibilidade de todo e qualquer sentido, pois assim, o sujeito não conseguiria enunciar invadido por um mar de palavras. Desse modo, ao nosso ver o silêncio trabalha tanto com a pluralidade de sentidos quanto na regulação dos sentidos, mas de modo diferente dos esquecimentos. Quanto ao conceito de formação discursiva, Orlandi (2007a) assinala que o silêncio trabalha os e nos limites das formações, jogando com a contradição de sentidos e com a identificação do sujeito, permitindo que sentidos apareçam como lusco-fusco.

A autora localiza o silêncio como fundante, posto que é "[...] matéria significante por excelência, um continnum significante [...]" e, conclui que "[...] o real da significação é o silêncio. [...]” e mais, que, “[...] o silêncio é o real do discurso" (Orlandi, 2007a, p. 29). Explica uma diferenciação entre o silêncio inerente às palavras e o silenciamento, dois processos diferentes mas que se enlaçam no processo de produção de sentidos.

[...] I. há um modo de estar em silêncio que corresponde a um modo de estar no sentido e, de certa maneira, as próprias palavras transpiram silêncio. Há silêncio nas palavras; 2 . O estudo do silenciamento (que já não é silêncio mas 'pôr em silêncio') nos mostra que há um processo de produção de sentidos silenciados que nos faz entender uma dimensão do não-dito absolutamente 
distinta da que se tem estudado sob a rubrica do 'implícito'. [...] (Orlandi, 2007a, p. 11-12).

Diferenciando sua concepção de silêncio da concepção de implícito de Ducrot, a autora afirma que no implícito há um recorte feito entre o dito e o não-dito, entre significação atestada e significação manifesta, sendo o não-dito remetido ao dito. Em sua concepção de silêncio, o propõe não o remetendo ao não-dito, apostando que o silêncio significa. Assinala sim que há uma dimensão do silêncio que remete à incompletude da linguagem pela relação intrínseca do dizer com o não-dizer. Nessa relação, “O silêncio é assim a 'respiração' (o fôlego) da significação; um lugar de recuo necessário para que se possa significar, para que o sentido faça sentido. Reduto do possível, do múltiplo, o silêncio abre espaço para o que não é 'um', para o que permite o movimento do sujeito" (Orlandi, 2007a, p. 13). O silêncio existe entre as palavras, as atravessa, indica que o sentido pode ser outro, que o mais importante não se diz, e por isso, a autora o considera "fundante".

Torna-se importante esclarecer que quando Orlandi (2007a) apresenta o silêncio como fundador não o coloca como originário, nem como o lugar do sentido absoluto, nem que ele contém um sentido independente, pré-existente. Ao contrário, o silêncio como fundante é a garantia do movimento dos sentidos, é a possibilidade do sujeito trabalhar sua contradição constitutiva, no jogo do "um" com o "múltiplo", no jogo das significações, já que um discurso sempre remete a outro discurso. Trabalhando os entornos do impossível, do silêncio como o real do discurso, a autora prossegue sua análise ao silêncio e aos seus processos, delineando de maneira mais aprofundada o que chama de silêncio fundador e o que chama de política do silêncio. Vejamos:

O silêncio fundador, aquele que existe nas palavras, que significa o não-dito e que dá espaço de recuo significante; e b) a política do silêncio, que se subdivide em: bI) silêncio constitutivo, o que nos indica que para dizer é preciso não-dizer (uma palavra apaga necessariamente as 'outras' palavras); e b2) o silêncio local, que se refere à censura propriamente (àquilo que é proibido dizer em uma certa conjuntura). Isso tudo nos faz compreender que estar no sentido com palavras e estar no sentido em silêncio são modos absolutamente diferentes entre si. E isso faz parte da nossa forma de significar, de nos relacionarmos com o mundo, com as coisas e com as pessoas. (p. 24).

A autora destaca que o silêncio fundador indica que o processo de significação tem uma relação necessária com o silêncio e que a política do silêncio implica que o sentido é produzido sempre a partir de uma posição do sujeito que, ao dizer, estará necessariamente não dizendo 
sentidos outros, seja pelo efeito do silêncio constitutivo seja pelo efeito do silêncio local, a censura. Assim, “[...] Dizer e silenciar andam juntos.” (Orlandi, 2007a, p. 53) e sua dimensão política recorta o dizer. "Quando atentamos para o silêncio, tematizando razões constitutivas, fazemos o percurso da relação silêncio/linguagem e estamos no domínio do silêncio fundante. Quando circulamos pelas razões políticas, trabalhamos a dimensão do silenciamento na ‘formulação' dos sentidos” (Orlandi, 2007a, p. 54).

Podemos apontar, no entanto, que a política do silêncio está assentada no fato de que o silêncio faz parte dos processos de significação, em sua dimensão fundante. Portanto, como já dissemos, são processos (silêncio fundador e política do silêncio) que se atravessam mutuamente. "A diferença entre o silêncio fundador e a política do silêncio é que a política do silêncio produz um recorte entre o que se diz e o que não se diz, enquanto o silêncio fundador não estabelece nenhuma divisão: ele significa em (por) si mesmo" (Orlandi, 2007a, p. 73). Fazendo uma relação entre silêncio e sentido, de acordo com a autora, não há sentido sem silêncio porque o silêncio é matéria significativa, assim “[...] Não há oposição entre silêncio e palavra mas solidariedade." (Orlandi, 2014, p. 4).

Conforme a fundadora desse conceito, o silêncio fundador é o princípio de toda significação, é a condição mesma da produção de sentido e é o que permite que a linguagem signifique. É não só o entremeio das palavras, mas é aquilo que as atravessa e as torna porosas. O silêncio local é a interdição do dizer, é a interdição da inscrição do sujeito em formações discursivas determinadas, e consequentemente, a proibição do sujeito a ocupar certos lugares, certas posições-sujeito. Retomando Pêcheux (2009b), podemos dizer que essa proibição não é sem o seu inverso, a resistência, e podemos ainda afirmar que nos poros da proibição e da resistência está o silêncio fundador, para remeter a outros sentidos. Está o real do discurso, como aquilo que é inapreensível. No jogo de silenciar e significar, o contorno do imaginário cria a ilusão da unidade e da diferença, o contorno do simbólico aponta a multiplicidade de sentidos, que, no entanto, não são quaisquer pelo efeito das condições de produção de cada dizer.

Pensando que o silêncio sustenta a produção do dizer, daremos mais um passo na obra pecheuxteana com a contribuição de Payer (2005) que se debruça a estudar o sujeito e o corpo no contexto da pós-modernidade, atravessado por enunciados que determinam o que pode e deve ser dito e que, portanto, silenciam e fazem o silenciamento de outros sentidos, e se emolduram pelo poder do Mercado. 


\subsection{0 sujeito e os processos de imposição/dissimulação e interpelação/identificação pelo poder do Mercado}

Conforme vimos com Pêcheux (2009a), os processos de imposição/dissimulação constituem o sujeito ao mesmo tempo em que dissimulam o assujeitamento. Tais processos se dão no que Althusser (1996) aponta como a interpelação do sujeito como sujeito "livre" que "livremente" se submete ao Sujeito, aceitando "livremente" a sua submissão. Nesse tecido de evidências no qual se contitui o sujeito, ele se identifica ao Sujeito, ou ainda como vimos, se contra-identifica, se desidentifica, havendo também falha no ritual. Porém, a identificação está posta de alguma maneira, já que só é possível ao sujeito se contra-identificar ou se desidentificar a partir de uma identificação primeira. No processo da interpelação/identificação, a ideologia fornece evidências que fazem com que um enunciado queira dizer o que realmente diz, sob o efeito da transparência da língua, e que mascara o seu caráter material que é da ordem da opacidade. Payer (2005, p. 13) aponta que o enunciado é a forma material que condensa o modo como o sujeito se constitui atravessadao pelas instituições de poder, e afirma que, atualmente, o Mercado é o grande Sujeito que nos interpela ideologicamente. Sugere, portanto, a “[...] demanda social de uma nova forma de sujeito [...]".

Sustentando o fato de "[...] que os modos de ser sujeito ao longo da história social não se apresentam sempre idênticos. [...]” (p. 13), dadas às condições de produção dos enunciados e do que a ideologia autoriza a circular, a autora aponta, de acordo com os trabalhos de Haroche, Pêcheux e Foucault, que os sujeitos se constituem diferentemente. Acrescentamos que, ainda que os processos de imposição/dissimulação e interpelação/identificação se dêem da mesma forma na constituição dos sujeitos, os enunciados que são legitimados nesses processos, por serem diferentes em função dos diferentes contextos sócio-históricos, resultam em formas de sujeito diferentes, porém, sujeitos. Pautada em diferentes contextos sócio-históricos, Payer (2005) traça uma leitura sobre o modo como o Mercado atravessa e constitui a forma de assujeitamento na pós-modernidade.

A autora se apóia em Haroche (1992) para abordar enunciados da Idade Média, da Idade Moderna sustentados pelo Poder da época, para trabalhar com enunciados atuais sustentados pelo Poder do Mercado. Payer (2005) diz, então, que, na passagem da Idade Média para a Moderna (século XVI), houve uma transferência do Poder da Religião para o poder do Estado, transferência legitimada, sobretudo, pelos ideais da Revolução Francesa. Portanto, se na Idade Média, a estrutura social era predominantemente regida segundo as leis divinas e em nome de 
Deus se legitimava a divisão social entre súditos, senhores e nobreza, já com a Revolução Francesa e o Poder transferido para o Estado, as leis divinas foram substituídas pelas leis jurídicas e, nessa passagem, os indivíduos passaram a ser considerados cidadãos, livres. Assim, a partir da produção social de uma transformação histórica do domínio do Poder, decorreu também uma transformação histórica dos sujeitos.

Afirma, então, que, na pós-modernidade, o poder do Mercado tem se fortalecido frente ao poder do Estado a partir da globalização econômica e da diluição das fronteiras nacionais.

\begin{abstract}
Mas o que estamos querendo ao trazer à cena estes elementos de ordem aparentemente externa à linguagem, vamos dizer de ordem econômica, social e política no sentido amplo, é circunscrever agora um fato mais propriamente discursivo: é que a transformação no poder das instituições sociais se faz acompanhar de uma transferência de poder entre enunciados. Ou seja, em cada tempo histórico há enunciados que funcionam como fundamentais, enquanto máximas capazes de condensar o conteúdo que exerce a interpelação ideológica dos indivíduos em sujeito', para retomar a conhecida expressão de Althusser. Consequentemente, com a alteração das instâncias do Poder, de um tempo histórico para outro, alteram-se também os encunciados fundamentais das práticas discursivas (Payer, 2005, p. 14-15).
\end{abstract}

A partir da leitura desse processo de produção de enunciados em diferentes contextos sócio-históricos, a autora identifica uma transformação progressiva do Poder na medida em que o valor atribuído à lei jurídica associada como enunciado fundamental do Estado tem sido substituída pelos enunciados do Mercado. Para explicar os enunciados do Mercado, a autora se apóia na noção de texto e afirma que se o Livro Sagrado é o Texto fundamental da prática discursiva religiosa na Idade Média, se a Constituição é o Texto fundamental do Estado na Idade Moderna, o Texto fundamental da sociedade pós-moderna é a Mídia, compreendendo a forma material do discurso, lugar material onde a relação língua e ideologia produz efeitos, dado que a ordem do discurso se materializa na estruturação do texto.

Segundo Payer (2005), a mídia se apresenta como forma textual onipresente, marcada pela imagem, produzindo efeitos de evidência de sentidos, e, tecendo articulações com o conceito de silêncio de Orlandi (2007a), podemos dizer que por meio do Texto legitimado, uma forma de dizer é eleita enquanto outras são postas constitutivamente em silêncio e, ademais, podemos dizer do silêncio local, já que, de certa maneira, sentidos sobressaem-se calando sujeitos. Por exemplo, na pós-modernidade, o poder do Mercado enquanto Texto marca que a lei é o consumo, algo do qual é quase impossível escapar. 
Payer (2005) fazendo paralelos entre os Textos aos quais se referiu, ou seja, o Texto religioso, o Texto do Estado e o Texto midiático, explica cada um dos enunciados-máxima que se enlaçam a estes legitimando sentidos em dados contextos sócio-históricos. Desse modo, a autora afirma que, na ordem religiosa, o enunciado-máxima é o da obediência à lei divina, a recompensa pela obediência é a salvação da alma e, o castigo, a sua perda, ou seja, a perdição da alma. Nesse contexto, o corpo é discursivizado como separado da alma. De acordo com a autora, se na ordem do Estado a máxima é a obediência à lei jurídica, a recompensa pela obediência é a liberdade de expressão, os direitos e os deveres. Nesse paradoxo, o corpo passa a ter a condição da livre circulação, uma recompensa pela vida civil. A punição para esse corpo livre, no caso, é a prisão. Também um paradoxo porque o que há são efeitos de liberdade, o corpo não é livre. Já na ordem do Mercado, segundo Payer (2005), o enunciado-máxima é a palavra "sucesso" e o descumprimento da lei midiática é o anonimato.

Para a autora, “[...] nas práticas discursivas há lugares que são construídos especialmente para este fim de propagação do enunciado, e que se tornam seus verdadeiros ícones [...]” (p. 18). Desse modo, o templo é o lugar do enunciado religioso, o tribunal o lugar do enunciado jurídico e o shopping o lugar dos enunciados do Mercado. Aprofundando seu gesto de interpretação ao Mercado, Payer (2005) aponta que o shopping é para onde convergem os enunciados do Mercado, contudo o seu grande Texto não tem um lugar único, é disperso e onipresente na mídia, e podemos dizer que cria um efeito de onipresença em nosso contexto sócio-histórico já que se presentifica nas residências e em qualquer lugar de circulação pela via dos objetos tecnológicos de conexão à rede eletrônica e atualmente pelas lojas e propagandas online. Enquanto o templo e o tribunal se constituem como arquiteturas físicas, “[...] a mídia se constitui como lugar não-material - pelo menos no sentido da sua arquitetura. [...]” (p. 19) e nos efeitos do não-material, podemos dizer que se enlaça à onipresença e à onipotência, antes atribuída à Deus.

Assim, “[...] o sujeito pego na injunção ao sucesso é aquele em que mais firmemente funciona a 'ilusão de completude', de que fala E.Orlandi (2001), ou a ilusão de que um dia se vai 'chegar lá', nas palavras de S. Rolnik (1989) [...]” (p. 20). A partir dessa ilusão se constitui uma forma-sujeito que tudo quer na crença de que atingirá a plenitude suposta no sucesso. Há assim um ideal de sujeito determinado. Segundo Payer (2005), uma consequência da obediência às leis do mercado é o esgotamento, também do corpo, pois “[...] se é possível acompanhar em tempo real o ritmo do virtual no plano dos sentidos, do simbólico, no plano corporal, entretanto, não há, por princípio, como o corpo acompanhar o ritmo do virtual [...]” (p. 21). 
Esta dimensão de encenação da mídia constitui um dos modos pelos quais o Mercado cria seu efeito de 'saturação dos sentidos, conforme a expressão de M. Pêcheux (1988), parecendo não deixar espaços além de si para nada, para nenhum outro discurso, para nenhuma outra forma de sujeito, para nenhum corpo que não lhe sirva como suporte. A julgar pela Mídia, tudo se passa como se não houvesse exterior ao Mercado [...] (Payer, 2005, p. 19).

Retomando Pêcheux (1969), é trabalho da ideologia criar um efeito de evidência nos sentidos, velando ao sujeito outros sentidos diferentes dos legitimados. No silenciamento (Orlandi, 2007a) de outros sentidos, segue a mídia fazendo valer o poder do Mercado, e acrescentamos, do Consumo, no jogo da oferta, no fluxo de mercadorias e de informações, criando a demanda por objetos tecnológicos que prometem cada vez mais velocidade, armazenamento e acoplamento ao corpo. Nas palavras de Romão (2007, p. 218),

Nesse sentido, a contemporaneidade, sustentada por um imaginário de
potência derivado das “tecnologias digitais, multimídia", repete em uníssono
uma mensagem tida como inevitável e urgente: a ordem é entrar nas redes de
informação para se comunicar, ser alimentado por notícias recentes, assistir à
nova programação de entretenimento, ouvir as músicas de sucesso, conhecer
e plugar-se em um mundo que está aberto dia e noite, por fim, ter acesso à
navegação com dados simultâneos a sua ocorrência. Os portais eletrônicos, a
programação televisiva, as estações de rádio, o correio eletrônico, as revistas
semanais e os jornais diários com versões on-line, as atrações ao vivo
promovem uma atualização permanente, criando a ilusão de um presente sem
fim com fluxo contínuo de alimentação e de circulação, algo que Bucci (2004,
p. 35) definiu como um 'gerúndio interminável [...] que não tem começo nem
fim"”.

Abordando uma de nossas questões dessa pesquisa apontamos que, embora o corpo compareça com seu limite, os discursos movidos pela lógica do Mercado trabalham com um empuxo ao comparecimento do corpo no tecnológico, clamando um não limite, um consumo, até dormindo, empuxo que podemos denominar como o gerúndio interminável demarcado na citação acima. Para tecermos uma leitura sobre o poder do Mercado delineado por Payer (2005), trazemos a postagem "Minha vida", compartilhada na rede social Facebook, em janeiro de 2013. 


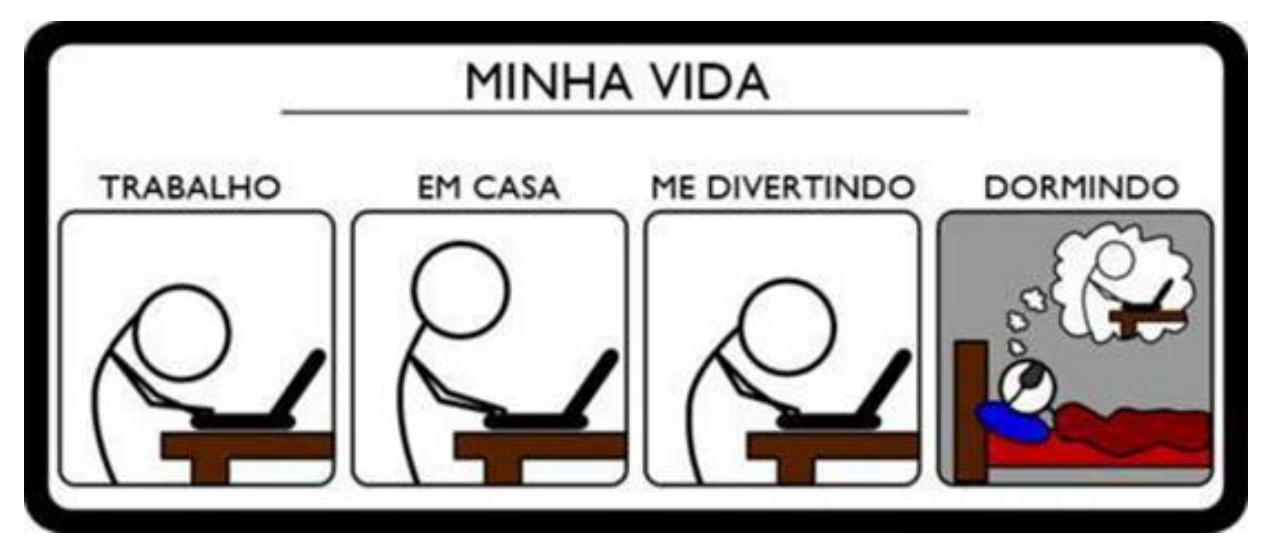

Figura $2^{7}$

Para iniciar, faremos uma leitura sobre a interpelação do sujeito pela ideologia, na qual assinalamos que o poder do Mercado é sustentado por formações ideológicas materializadas em formações discursivas que atravessam o dizer dos sujeitos, que, ao se identificarem ao que podemos nomear de formação discursiva do mercado, constituem também o que podemos nomear como forma-sujeito do mercado a qual caracteriza uma posição-sujeito no discurso com seu corpo. Retomando o que Pêcheux (2009a) propõe como forma-sujeito do discurso, havendo uma identificação à formação discursiva, estamos diante do que o fundador nomeia como o "bom sujeito", aquele que se deixa atravessar pelo sentido dominante de um contexto sóciohistórico.

Podemos dizer que as formulações discursivas que compõem a charge, sinalizam uma filiação ao sentido dominante, no qual o corpo é convocado a se manter conectado ao objeto tecnológico de conexão à rede eletrônica, consumi-lo e por ele ser consumido, até dormindo, num fluxo contínuo, bem apontado por Romão (2007). A série "Trabalho", "Em casa", "Me divertindo", "Dormindo", aponta uma equivalência na posição-sujeito "assumida", e silencia, conforme Orlandi (2007a) nos apontou antes teoricamente, outras formas de se posicionar em cada um desses momentos que compõem a vida. Assinalamos, assim, enunciados que afirmam a onipresença do objeto na vida retratada e a onipresença do sujeito com seu corpo na rede eletrônica, presenças ilustradas na ordem do ilimitado. Por meio da Figura referida, também podemos estabelecer uma interlocução com a Figura 1, na qual o cabo de rede é afixado na veia

\footnotetext{
${ }^{7}$ Recuperado em 17 de abril de 2014, de https://www.google.com.br/search?sa=G\&hl=pt\&q=modern+life\&tbm=isch\&tbs=simg:CAQSjAEaiQELEKjU2 AQaAggKDAsQsIynCBpiCmAIAxIouwiHFLAI7gGeA_10J1wPqE70I5gGfNI40pj3tM7E0pz3yM4w9vz22NBo wGd0MJZb_1hslWuat3pqlcnBJZZy6zFDXZa_1fVFoinNoArFLKJ5kh6OYN_1uzirzpJIAMMCxCOrv4IGgoKCAgBEgTgvEaZDA \&ved=0ahUKEwif4qro74vLAhWMIZAKHZtvDQ4Qwg4IGigA\&biw=1366\&bih=667
} 
de um braço, perpassando sentidos de um corpo online, conectado, da rede dependente, e na presente Figura, um corpo que não se desconecta nem em sonho.
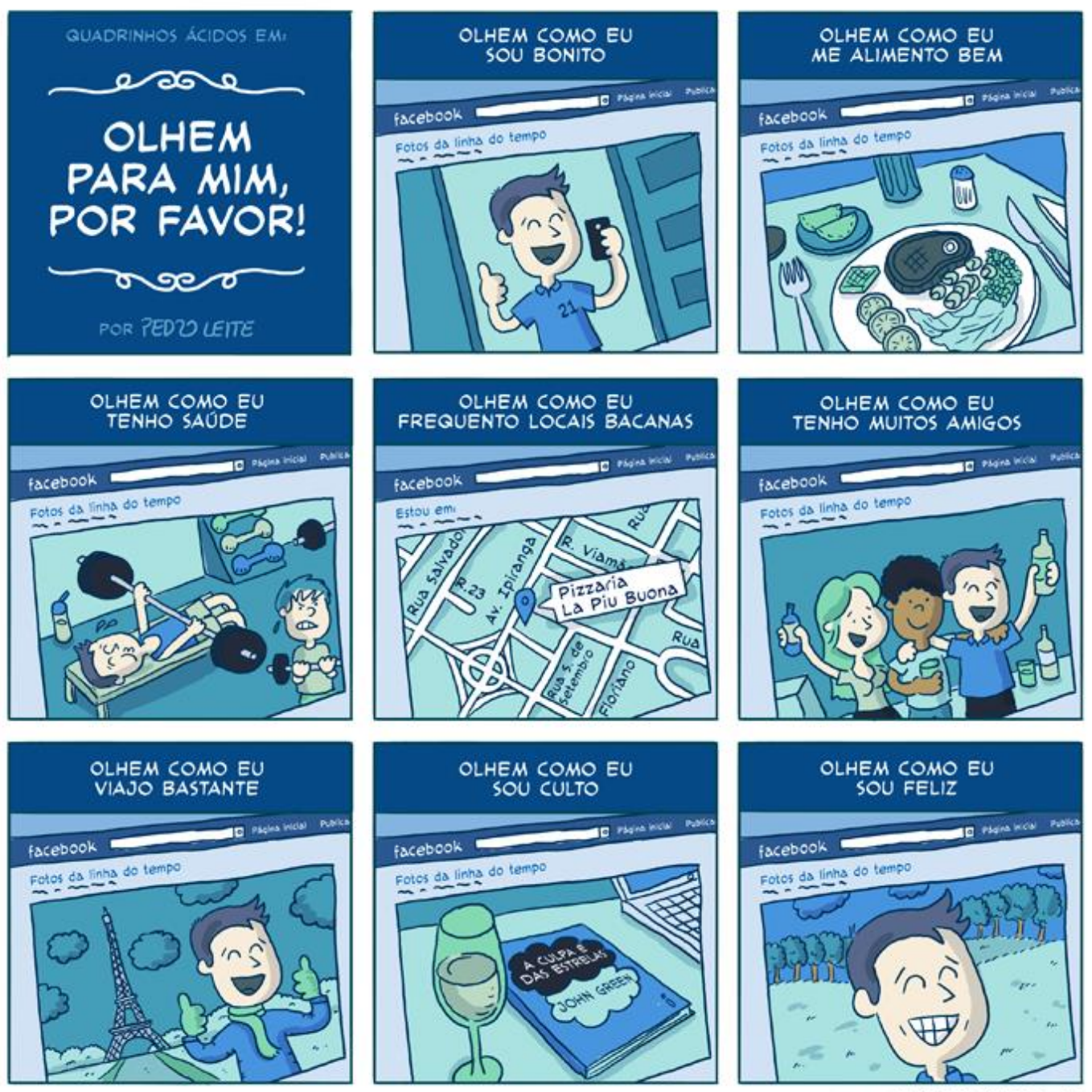

www.quadrinhosacidos.com.br

Figura $3^{8}$

Trazemos essa outra postagem compartilhada na rede social Facebook, em junho de 2013, a partir de um site de quadrinhos. Como vimos anteriormente, Payer (2005) assinala a mídia como uma forma textual onipresente e essa onipresença também podemos observar na relação dos sujeitos com os produtos do Mercado, ao se esquivarem do anonimato, punição para aquele que não se filia ao poder do Mercado. Ao que a autora elenca como "sucesso", podemos dizer de uma busca pela visibilidade, que faz oposição ao anonimato. Tal visibilidade

\footnotetext{
${ }^{8}$ Recuperado em 12 de maio de 2014, de www.quadrinhosacidos.com.br
} 
é produzida na formulação "Olhem para mim, por favor", na repetição de "Olhem" e nas repetidas cenas em que o sujeito se posta na rede social, consumindo o objeto tecnológico, consumindo a rede, ofertando-se para consumo, entrando no mesmo jogo de oferta-demanda dos enunciados do Mercado. Nas formulações discursivas também podemos assinalar a formasujeito, enquanto posição no discurso, e o "bom sujeito" (forma-sujeito da identificação) constituindo-se na ordem do Mercado. Podemos, assim, assinalar, como o corpo é convocado à mostração e a um ideal de sujeito que pode consumir livremente e dar-se ao consumo, convocando o olhar do outro/Outro: "Olhem para mim". Portanto, o Mercado convoca não ao mero consumo, mas convoca o olhar para o consumo.

Prosseguindo no estudo do poder do Mercado, encontramos Braunstein (2010), no campo da psicanálise, tecendo algumas articulações sobre o que ele denominou de discurso do mercado, a partir da teoria dos quatro discursos articulada por Lacan (1992), a qual abordamos na seção 1.1 pelas relações levantadas por Plon (2012) entre a teoria do discurso de Pêcheux e a teoria do discurso de Lacan. Torna-se importante destacar que a teoria dos quatro discursos, assim como o discurso capitalista e o discurso do mercado não serão tomados aqui em sua visada clínica, mas naquilo que a escuta psicanalítica nos auxilia a vislumbrar quanto ao agente do discurso e seus efeitos, na especificidade do discurso do mercado. Consideramos que tal leitura traz acréscimos ao que Pêcheux (2009a) concebe como o processo do Significante na interpelação e identificação dos sujeitos na pós-modernidade, na questão que atravessa o sujeito como processo, advindo da rede de significantes. Passaremos às contribuições do autor, contextualizando inicialmente de onde advém a concepção de discurso do mercado.

De acordo com Braunstein (2010, p. 143), "Lacan respondeu aos acontecimentos que sacudiram a cultura ocidental em 1968 com sua conhecida teoria dos quatro discursos de 1969. Essa concepção articulava a compreensão da subjetividade, tal como aparece na clínica psicanalítica e nos processos históricos. [...]”. Retomando o que já dissemos na seção 1.1, a estrutura da teoria é sustentada na concepção de sujeito barrado (\$), representado por um significante (S1) para outro significante (S2), restando dessa operação o objeto $a$; tais elementos são dispostos em lugares, quais sejam: agente, verdade, Outro, produção. De acordo com Braunstein (2010), em 1971 e 1972, Lacan criou a fórmula do discurso capitalista, movendo o discurso do mestre. Aponta que em 1972, Lacan anunciou um novo discurso, chamado "PS" ou "PST", ou "PESTE", ao seu ver, inteiramente consagrado ao capitalismo. É esse discurso anunciado por Lacan que o psicanalista argentino chama de discurso do mercado, o qual traz um novo avatar do amo, não mais o senhor do discurso do mestre, nem o capitalista do discurso capitalista. 
Braunstein (2010) aponta, então, que o mestre antigo, aquele que promovia a formação de indivíduos juridicamente regulados, foi substituído pelo mestre moderno, aquele que incita a satisfação de aspirações. Nesta relação de mestria, o mestre antigo governava a repressão e o mestre moderno o gozo, e segundo o psicanalista argentino, Lacan deu o nome de discurso capitalista ao mestre moderno. O discurso capitalista é aquele que se caracteriza pela recusa da castração simbólica, ao passo que esta faz sua entrada justamente pelo discurso analítico, que nasce com Freud. O discurso capitalista instaura uma transformação no discurso do mestre como consequência de seu encontro com as ciências e com os objetos técnológicos que delas advêm, as "latusas" (Lacan, 1992), chamadas por Braunstein (2010) de "[...] servomecanismos para designar esses artefatos que a ciência permite fabricar e enviar ao mercado para seu consumo massivo e que estão destinados a uma rápida obsolescência, objetos que chamaríamos prêt à porter, ou melhor, prêt à jouir, que funcionam como análogos do objeto causa do desejo, do objeto@ $@$ [...]" (p. 149).

Trabalhando a fórmula do discurso do mercado ${ }^{9}$ elaborada pelo psicanalista argentino, o lugar do agente no discurso do mercado é o objeto $a$ representado pelo o que chamou de "servomecanismos", objetos que intimam o sujeito (\$) a produzir significantes mestres (S1) aos quais subordinará sua existência. A verdade é ocupada pelo saber (S2), o saber científico que se incorpora na produção dos objetos descartáveis a serviço do mercado, e aos quais o sujeito se consagra. Como se pode ver, o discurso do mercado tem a mesma estrutura do discurso do analista, porém essa homologia conduz ao oposto. Podemos dizer que o mercado cria objetos que se acoplam no objeto $a$, inexistente, mas que tem a função de causar o desejo, como veremos no próximo capítulo. Já o objeto $a$ no discurso do analista tem a função de causar o desejo, estando o sujeito advertido de que não há objeto que cesse o desejo. Assim, embora o discurso do mercado e o discurso do analista tenham a mesma estruturação, as funções dos elementos nos lugares dispostos são muito diferentes, pela vetorização. Conforme Fingermann (2010, p. 343), "Instalar o objeto pequeno a no lugar do semblante [semblant] [...], é não produzi-lo nem reproduzi-lo como verdadeiro [...]"; deste modo, o discurso do mercado é um outro discurso, e o descrevendo e descrevendo seus efeitos, Braunstein (2010, p. 155-156) aponta que

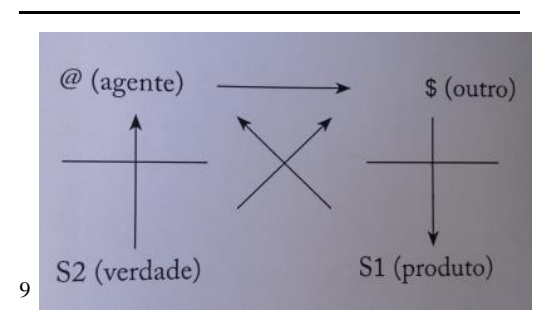


Vemos ocupando o lugar do agente um ser sem rosto, que não diz palavra alguma. A lógica discursiva dos mercados apresenta-se como um conjunto de tráfegos, de vai e vens cibernéticos, fora do tempo e do espaço, sem sujeito nem fim(ns). Poderíamos dizer que o semblante não é o do "capitalista" (nem Henry Ford nem Bill Gates), senão o mercado com seus inescrutáveis "fluxos de capital". Essa misteriosa entidade muda e retumbante, podemos reconhecêla como $a$, causa do desejo, mais-de-gozar, emissora de um discurso sem palavras e de uma ordem enunciada em surdina, que pode ser sanguinária, a do supereu: "Goza!". Na realidade, o agente é Ninguém (Personne); não poderíamos confundi-lo com o mestre tradicional. A batuta e também a voz cantante em nosso mundo "globalizado" correspondem ao "objeto", à mercadoria que impõe suas condições. Quem substituiu o capitalista, que por sua vez havia substituído o mestre antigo? O dispositivo definido por Agamben como "tudo o que tem, de uma maneira ou de outra, a capacidade de captar, orientar, determinar, interceptar, modelar, controlar e assegurar os gestos, as condutas, as opiniões e os discursos dos seres vivos" (AGAMBEN, 2007, p. 31). Lacan deixou indicada a resposta que estamos desenvolvendo: o saber que originalmente pertencia ao escravo (S2): esse "saber fazer" e esse saber inconsciente que este manifestava quando o mestre lhe fazia as perguntas que permitiam revelá-lo, esse saber está agora incorporado no objeto. Ele sabe como fazer, sempre e quando se respeite a "programação" do servomecanismo, sempre e quando se obedeça ao mode d'emploi. Esse "tudosaber" (que não é "saber-de-tudo") à disposição do novo mestre. (Braunstein, 2010, p. 155-156).

O autor afirma que no capitalismo o operário substituiu o escravo, já no discurso do mercado, o operário tem sido substituído pelo objeto tecnológico, não de forma caricatural como nos filmes de ficção científica, mas na forma de dispositivos cada vez menores, mais portáteis e repletos de funções. Os objetos tecnológicos produzidos massivamente e condenados a uma obsolescência cada vez mais rápida, descartados e substituídos por outros, " [...] deram um novo rosto à sociedade do capitalismo tardio e são a concreção material de um novo discurso, ao qual podemos caracterizar com os matemas da álgebra lacaniana. [...]” (p. 156). Assim, o objeto $a$ é o agente do discurso do mercado como aquele que faz agir. No lugar da verdade está o saber (S2) e é ele quem comanda o agente.

Para Braunstein (2010), a ciência como uma "empresa" é esse saber que faz proliferar os gadgets. É um saber que não quer saber nada do sujeito nem daquele que o comanda e que é ignorante de suas determinações sociais e políticas e que obedece às suas próprias leis. Segundo o psicanalista, trata-se de "[...] uma "ideologia da foraclusão do sujeito" cuja máxima expressão se encontrará na doxa econômica que postula que os mercados funcionam sozinhos, regidos por suas próprias leis, independentemente da vontade de seus atores e daqueles que são afetados pelos movimentos do capital. [...]” (p. 156-157). Braunstein (2010) propõe que o “outro" ao qual se dirige o objeto $a$ é o sujeito (\$), “[...] o usuário e consumidor dos produtos 
tecnocientíficos, o sujeito que já não está representado por um significante para outro significante [...]" (p. 157). O sujeito que se acredita autônomo quando maneja controles remotos, quando decide entre marcas. É ele quem recebe os vetores que partem do lugar da verdade (S2) e do agente (a). O produto é o “[...] 'homem unidimensional' marcusiano, o consumível sujeito da sociedade de consumo [...]" (p. 157).

Podemos dizer que a articulação do psicanalista argentino vai ao encontro da articulação de Payer (2005) sobre o poder do Mercado, na medida em que, sendo esse um discurso legitimado ideologicamente, atravessa o discurso dos sujeitos de um dado contexto sóciohistórico, configurando as formas sujeito do discurso via identificação, desidentificação e contra-identificação. Salientamos que não se trata da mesma teoria, nem do mesmo campo teórico, posto que Payer (2005) está no campo da Análise do Discurso e Braunstein (2010) no campo da Psicanálise. Porém, os efeitos de análise de ambos tecem laços de interlocução que muito colaboram para a escuta dessa pesquisa.

Apresentamos nesse capítulo um panorama conceitual da Análise do Discurso elaborada por Pêcheux, a contextualizamos, e a articulamos de certo modo com os campos que a constituíram, apresentando ainda a continuidade da teoria na voz de outros autores. Tal panorama faz-se fundamental para adentrarmos nos demais capítulos que norteiam essa pesquisa e, ao longo desse percurso não deixaremos de tecer o panorama conceitual da Análise do Discurso, suas articulações com outros campos do saber, e, sobretudo, nos arriscarmos a gestos de interpretação. Prosseguiremos nosso estudo sobre o objeto e sobre o objeto tecnológico de conexão à rede eletrônica, já discutido aqui por meio dos "servomecanismos" de Braunstein (2010) e pelas "latusas" de Lacan (1992) e daremos um passo a mais apresentando a noção de objeto para a Psicanálise e tecendo alguns gestos de interpretação ao que concebemos como objeto tecnológico e rede eletrônica. 


\section{A NOÇÃO DE OBJETO: DE DAS DING AO OBJETO TECNOLÓGICO DE CONEXÃO À REDE ELETRÔNICA}

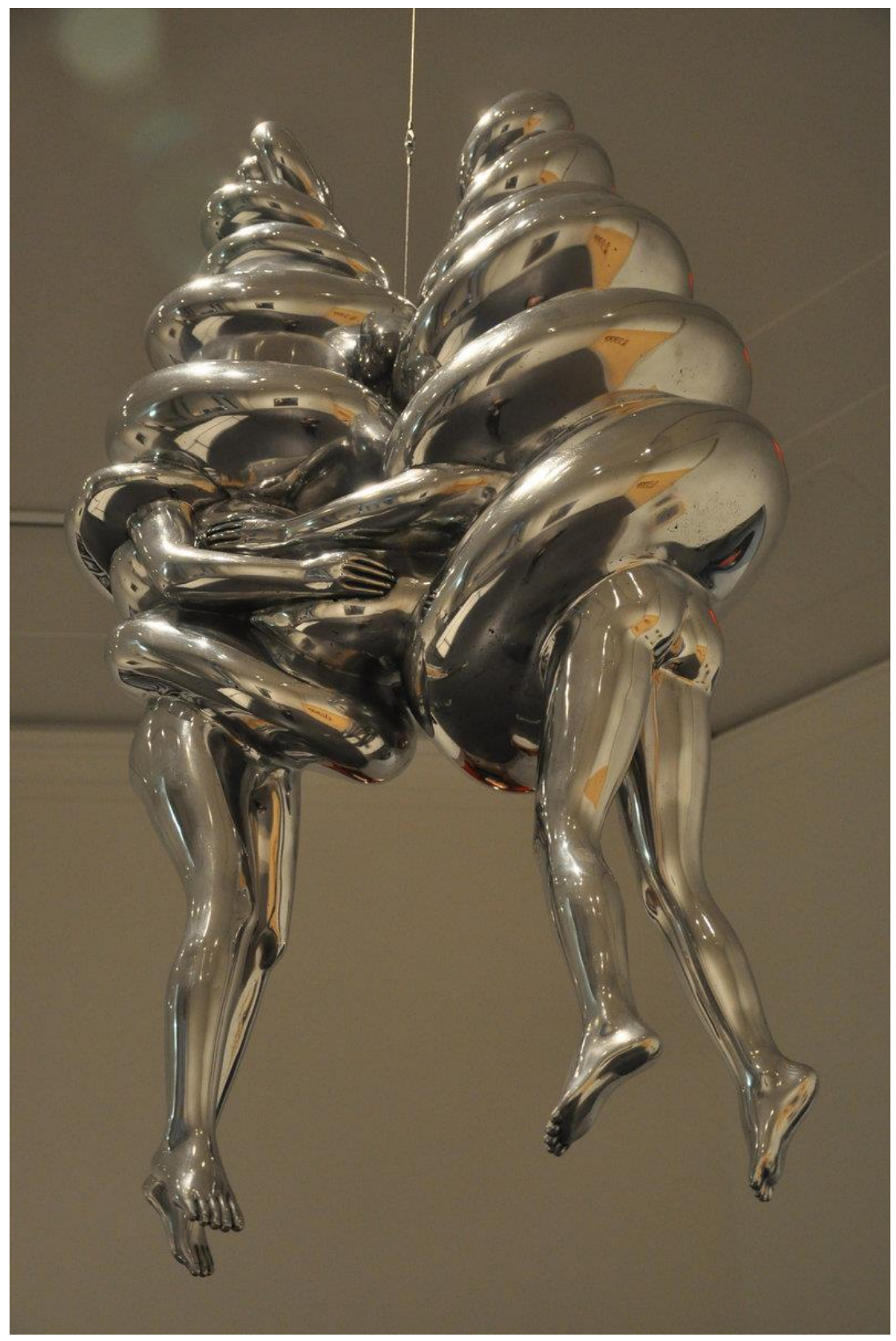

A Couple (Louise Bourgeois, 2003)

Vivo, vivíssimo

Intento ser, à minha maneira, um estóico prático, mas a indiferença como condição de felicidade nunca teve lugar na minha vida, e se é certo que procuro obstinadamente o sossego do espírito, certo é também que não me libertei nem pretendo libertar-me das paixões [...]. 
As questões que norteiam essa pesquisa foram formuladas a partir dos sentidos que circulam sobre o corpo em discursos sobre os objetos tecnológicos de conexão à rede eletrônica, visando a escutar o processo de produção dos sentidos e dos discursos inerentes a essa relação, corpo - objetos tecnológicos. Considerando que esses objetos são apresentados em sua faceta de potência, acentuada pelos enunciados do Mercado (Payer, 2005), consideramos importante abordar a noção de objeto para a Psicanálise posto que ela nos auxilia a pensar sobre a relação sujeito, corpo e objetos tecnológicos de conexão à rede eletrônica, para além dos sentidos de potência. A partir dessa noção, pudemos estabelecer o que concebemos como objeto tecnológico e, nos pautando em contribuições de autores da Análise do Discurso, apresentamos uma noção de objeto tecnológico que leva em consideração o processo de produção dos discursos que o constituem, que o imbuem de sentidos de potência. Pretendemos, portanto, apontar a faceta de falta inerente aos objetos tecnológicos de conexão à rede eletrônica, com Dias (2012), Romão (2004, 2005, 2012) e Orlandi (2012, 2007b, 2006), dentre outros autores.

Para elaborarmos esse capítulo, contamos também com a contribuição do campo da Cibercultura e da Informática, de autores como Lévy, (2004, 2005), Cebrián (1999), Castells (2003), Lemos (2010a, 2010b). Porém, enfatizamos mais uma vez que nos posicionamos de modo a compreender como os discursos se constituem e a desfazer os efeitos de transparência que incidem na relação sujeito, corpo e objetos tecnológicos de conexão à rede eletrônica, incluindo desfazer sentidos legitimados nos campos referidos. Abrir os poros dessa relação, é o nosso movimento de interpretação. Para tanto, iniciamos esse capítulo apresentando a noção de Das Ding e de objeto a para a Psicanálise.

\subsection{Das Ding ou a Coisa - a causa de desejo - os objetos da ciência e do mercado - o objeto do discurso}

Bauman (1998), no livro "O mal-estar da pós-modernidade", tece uma leitura sobre o texto freudiano "Mal estar na civilização" e afirma que, embora o autor preferisse falar de kultur ou civilização, é a história da modernidade que ele retrata. O sociólogo polonês aponta que "[...] Só a sociedade moderna pensou em si mesma como uma atividade da 'cultura' ou da 'civilização' e agiu sobre esse autoconhecimento com os resultados que Freud passou a estudar; a expressão 'civilização moderna' é, por essa razão, um pleonasmo" (p. 7). De acordo com ele, a mensagem de Freud nesse livro é: "Você ganha alguma coisa mas, habitualmente, perde em 
troca alguma coisa [...]” (p. 7). “[...] Os prazeres da vida civilizada, e Freud insiste nisso, vem num pacote fechado com os sofrimentos, a satisfação com o mal-estar [...]” (p. 8). Dessas citações do referido autor destacamos a questão da perda e do mal-estar.

Se os apontamentos de Bauman (1998) nos possibilitam tomar a referida obra freudiana para abordar o campo da modernidade e da pós-modernidade, por outro lado, queremos enfatizar outro aspecto nela contido que interessa ao nosso estudo: a relação do homem com os objetos (tecnológicos) e, sobretudo, o que Freud conceitua como "Das Ding", ou a Coisa, em outros trabalhos. Nomeação para algo "inominável” (Sousa, 2013, p. 62) e que se trata de um objeto que o sujeito supõe encontrável, indício de uma perda, ou melhor, de uma falta constituiva, que o movimenta. Nesse movimento que o causa, o sujeito supõe um objeto capaz de cessar sua busca, no entanto, nunca encontrável.

É desde "Projeto para uma psicologia científica" que Freud (1950 [1895]/1996f) fala da Coisa, “Das Ding”. Segundo Lacan (1995, p. 13), “[...] Freud insiste no seguinte: que toda maneira, para o homem, de encontrar o objeto é, e não passa disso, a continuação de uma tendência onde se trata de um objeto perdido, de um objeto a se reencontrar". Tal objeto é vislumbrado como aquilo que lhe falta, aquilo que o completará, que satisfará o seu desejo. Objeto que o sujeito supõe existente e que já um dia existiu, tendo-o perdido.

Uma nostalgia liga o sujeito ao objeto perdido, através da qual se exerce todo
o esforço da busca. Ela marca a redescoberta do signo de uma repetição
impossível, já que, precisamente, este não é o mesmo objeto, não poderia sê-
lo. A primazia dessa dialética coloca, no centro da relação sujeito-objeto, uma
tensão fundamental, que faz com que o que é procurado não seja procurado da
mesma forma que o que será encontrado. É através da busca de uma satisfação
passada e ultrapassada que o novo objeto é procurado, e que é encontrado e
apreendido noutra parte que não no ponto onde se o procura. Existe aí uma
distância fundamental, introduzida pelo elemento essencialmente conflitual
incluído em toda busca do objeto. Esta é a primeira forma sob a qual, em
Freud, aparece a relação de objeto. (Lacan, 1995, p. 13).

Freud delineia então a noção de objeto como “[...] uma relação profundamente conflitual do sujeito com seu mundo [...]” (Lacan, 1995, p. 14) e que abarca a oposição entre o princípio da realidade e o princípio do prazer. Em “Além do princípio do prazer”, Freud (1920/1996a) afirma que os eventos mentais são regulados pelo princípio do prazer na medida em que uma tensão desagradável é levada a sua redução para a evitação do desprazer ou produção de prazer. E acrescenta que o princípio do prazer é um método primário de funcionamento do aparelho mental, que sob a influência dos instintos de preservação do eu, é substituído pelo princípio de realidade, o qual não abandona a intenção de obter prazer, mas, no entanto, o adia. Aquilo que 
foi reprimido, segundo Freud (1920/1996a) insiste na busca da satisfação completa e na busca de uma experiência primária e primeira de satisfação. Ao longo de sua teorização, Freud (1920/1996a) percebe que há algo além do princípio do prazer que se trata da tendência ao retorno ao nirvana e faz associações ao instinto de morte nessa busca de um estado anterior das coisas, ao estado de inércia, de inanimação. Como diz Lacan (2008, p. 39), “[...] o princípio do prazer é um princípio de inércia [...]”.

O que tenho no espírito é, naturalmente, a teoria que Platão colocou na boca de Aristófanes no Symposium e que trata não apenas da origem do instinto sexual, mas também da mais importante de suas variações em relação ao objeto. 'A natureza humana original não era semelhante à atual, mas diferente. Em primeiro lugar, os sexos eram originalmente em número de três, e não dois, como são agora; havia o homem, a mulher, e a união dos dois (...)' Tudo nesses homens primevos era duplo: tinham quatro mãos e quatro pés, dois rostos, duas partes pudendas, e assim por diante. Finalmente, Zeus decidiu cortá-los em dois, 'como uma sorva que é dividida em duas metades para fazer conserva'. Depois de feita a divisão, 'as duas partes do homem, cada uma desejando sua outra metade, reuniram-se e lançaram os braços uma em torno da outra, ansiosas por fundir-se.' (Freud, 1920/1996a, p. 37-38).

A fusão segue sentido na busca de uma aquietação para o homem ao se deparar com o encontro do objeto procurado. Aquietação que não advém, posto que é justamente a angústia que comparece na aproximação ao objeto suposto, conforme Lacan (2005) desenvolverá no seminário 10, a angústia. Lacan (1995, p. 35) apresenta a noção de "falta do objeto" como central, como a mola da relação do sujeito com o mundo, posto que esse objeto é inexistente, ele é apenas suposto. Para Lacan (2008), é isso que Freud designa quando diz que o objetivo não é encontrar um objeto que corresponda ao representado, mas reencontrá-lo, convencer-se de que ele (ainda) está presente. O Ding como estranho é o que orienta o sujeito em relação ao mundo de seus desejos. Aquilo que se busca encontrar não pode ser reencontrado porque jamais existiu, entretanto, alguma coisa fica esperando por algo que "[...] é esse objeto, Das Ding, enquanto o Outro absoluto do sujeito, que se trata de reencontrar [...]" (Lacan, 2008, p. 68). Trata-se de um objeto que nunca foi perdido e trata-se essencialmente de reencontrá-lo, um paradoxo. Tal qual o paradoxo da constituição do sujeito na Análise do Discurso, onde o sujeito é interpelado pelo Sujeito absoluto e universal, o S de que fala Pêcheux (2009a), interpelação que o constitui como singular mas atrelado à identificação ao Sujeito universal, esse também somente suposto e nunca existente. Pela via da interpelação, o sujeito jamais será o Sujeito universal, nem o Sujeito universal é existente, ele é hipotético. Das Ding é o fora do significado, 
aquilo que é "inominável”, como apontou Sousa (2013), e irrecuperável posto que jamais existiu, a não ser como miragem.

Encontramos Das Ding ressoar na escrita de Authier-Revuz (2010, p. 253) quando aborda a não coincidência fundamental da nomeação no que concerne "[...] a falta de captura do objeto pela letra [...]", caracterizada na dimensão de uma perda, uma falha em nomear já que a verdade não se diz toda porque as palavras faltam, conforme ela cita Lacan. Falta que é constitutiva do sujeito tantas vezes tomada como ferida a ser consolada por ficções como o

[...] interminável inventário das línguas imaginárias as mais heteróclitas, mas que, no antes mítico de uma Idade de Ouro ou de um paraíso perdido da humanidade ou de uma infância, no alhures sonhado de territórios distantes, desconhecidos ou utópicos, no depois projetado pelos construtores de línguas artificiais, se reencontram no fato de que elas nomeiam 'bem' as coisas, sem perda, sem desvio, restituindo por aí mesmo os sujeitos, fantasmaticamente, esta coincidência consigo mesmo que, constitutivamente, lhes interdita sua língua real" (Authier-Revuz, 2010, p. 253-254).

Nesse antes mítico, de um paraíso perdido, podemos situar o mito de Aristófanes rememorado por Freud (1920/1996a), no qual as metades buscam reencontrar o estado fusional, a "coincidência consigo mesmo" suportada, como aponta Pêcheux (2009a), no "Eu sou", como vimos no capítulo anterior, ou ainda no "eu" freudiano, que cria uma ilusão de inteireza, a ser buscada, porque é castrada, é dividida. É a falta (de objeto) que mobiliza a busca, o desejo, e não a inteireza em si (posto que ela não existe). Justamente é o desejo que Lacan visa ao propor o conceito de objeto $a$, causa de desejo. Assim, o objeto a causa de desejo se diferencia essencialmente de um objeto que venha ocupar o lugar de desejo, posto que $a$ é apenas movência. Ainda, como aponta Soler (Seminário Teórico - Leitura do texto Televisão de Jacques Lacan, 11 de maio de 2015), “o desejo não tem objeto natural”10. E, acrescentamos, nem objeto artificial, como costumam ser chamados os objetos tecnológicos por alguns ciberculturistas.

Apresentando aqui o desejo, faz-se importante de antemão destacar esse conceito para Freud e para Lacan diferenciando-o da demanda e da necessidade. Segundo Roudinesco \& Plon (1988, p. 147), o desejo, para Freud, é o desejo inconsciente, que tende a se realizar. "[...] Em outras palavras, é no sonho que reside a definição freudiana do desejo: o sonho é a realização de um desejo recalcado e a fantasia é a realização alucinatória do desejo em si”. Freud aponta

\footnotetext{
10 "Le desir n'ai pas l'objet naturel". Fala pronunciada por Colette Soler no Séminaire Théorique - Lecture de texte "Télévision" de Jacques Lacan, por ela ministrado, no Centre Hospitalier Sainte-Anne, Amphithéâtre Morel - Pavillon Magnan, em 11 de maio de 2015, em Paris.
} 
que a necessidade encontra satisfação em objetos adequados, como o alimento, e o desejo está ligado a lembranças. Conforme esses autores, Lacan estabeleceu uma ligação entre o desejo pautado no reconhecimento, ou ainda, "desejo do desejo do outro", e o desejo inconsciente enquanto realização no sentido freudiano, diferenciando mais o desejo da necessidade do que fizera Freud. Por volta de 1953 - 1957, Lacan introduziu um terceiro termo: a demanda. “[...]. Esta é endereçada a outrem e, aparentemente, incide sobre um objeto. Mas esse objeto é inessencial, porquanto a demanda é demanda de amor. [...]”. Assim, a necessidade satisfaz-se com um objeto da realidade, ao passo que o desejo se instala na distância entre a demanda e a necessidade. Ele é hiância, intervalo. Também se torna importante abordar o conceito de gozo elaborado por Lacan. Diferenciando-o do prazer, o gozo reside na tentativa de ultrapassar os limites do princípio do prazer e está ligado a busca da coisa perdida. O gozo está associado a repetição e aos impasses quanto ao desejo. (Roudinesco \& Plon, 1988). Elencar uma série de objetos de desejo como, por exemplo, objetos tecnológicos de conexão à rede eletrônica, que fazem semblante de objeto $a$, é entrar no movimento do gozo.

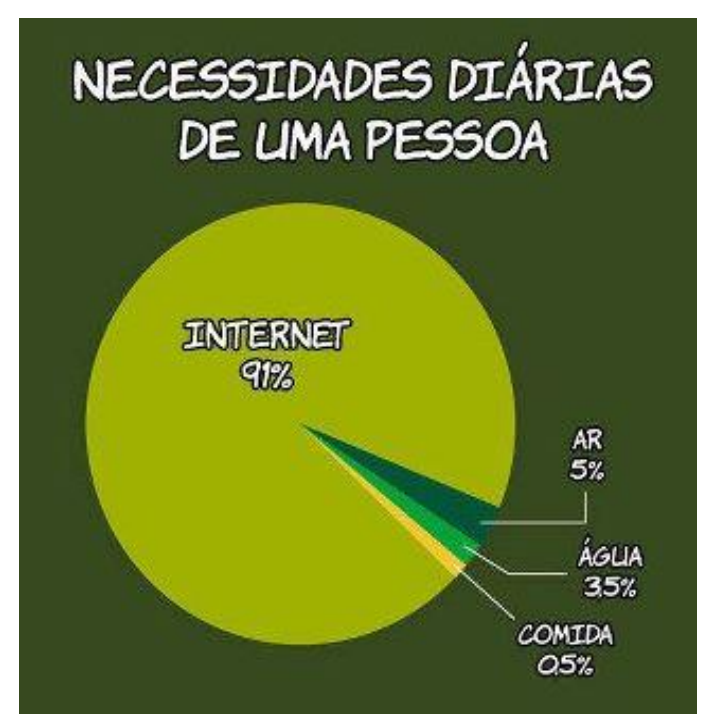

Figura $4^{11}$

Trazemos esse quadro que fora compartilhado na rede social Facebook em agosto de 2012, porque ele joga com sentidos, às avessas, sobre necessidade, do ponto de vista psicanalítico. Nele, a internet é discursivizada como uma necessidade e diremos uma supranecessidade (91\%), acima de qualquer outra necessidade vital (segundo a discursividade materializada no referido quadro). Podemos apontar que funciona um discurso que sustenta a

\footnotetext{
${ }^{11}$ Recuperado em 22 de agosto de 2012, de http://tdodia.webnode.com.br/divers\%C3\%A3o\%20imagens/
} 
oferta de um produto - a internet -, e cria a demanda por ele. Joga com o desejo, entre demanda e necessidade, apontando ainda um para além, o gozo repetitório - a internet está ilimitadamente ofertada ao sujeito - 24 horas por dia. Nesse para além de um gozo repetitório, apontamos o semblante de necessidade máxima que esse objeto assume nesse discurso, provocando o consumo, como se "não se pudesse viver sem internet", formulação discursiva que circulou consideravelmente no período desta postagem. Ademais, não podemos deixar de dizer sobre um discurso que sustenta a internet como incorporada, na medida em que passa a ser discursivizada como uma necessidade equivalente às necessidades do corpo biológico.

Traçado esse percurso no qual delineamos o mal-estar, o objeto e o objeto causa de desejo, retomamos nesse momento o texto "Mal estar na civilização", no qual Freud (1930/2010), trabalha a questão da relação homem-objeto, para tecermos algumas articulações sobre a constituição do eu na relação com o objeto eleito a ocupar o lugar de semblante de causar o desejo, desadvertido de que esse objeto é não encontrável. Faremos agora esse percurso para delinearmos como o objeto e o eu comparecem na constituição de uma suposta unidade, já que temos escutado sentidos de fusão (Lemos, 2010b; Haraway, 2009; Le Breton, 2003) na relação sujeito e objetos tecnológicos de conexão à rede eletrônica, relação que tomamos no campo do imaginário.

No texto referido, Freud (1930/2010) lança questões sobre as origens de um sentimento que nomeia como "oceânico", "ilimitado", "sem barreiras", que inunda o ser com a sensação de "eternidade". Sentimento e sensação ora relatados por um amigo, que os associa ao exercício de sua prática religiosa, de sua relação com Deus. O fundador da psicanálise se debruça a estudar tal sentimento e sensação na constituição dos sujeitos, abrindo a escuta para a repetição desses em outras relações como no caso do objeto amoroso, na qual o objeto comparece como aquilo que vai responder à busca do sujeito ao objeto perdido que supostamente irá completalo, satisfazê-lo, como no mito já citado de Aristófanes.

Para abordar o "sentimento oceânico", Freud (1930/2010) se debruça a estudar o eu e aponta que “[...] nada nos é mais seguro do que o sentimento de nós mesmos, de nosso Eu. Esse Eu nos aparece como autônomo, unitário, bem demarcado de tudo o mais. [...]” (p. 11). Todavia, sinaliza que essa aparência é enganosa porque o Eu serve como uma espécie de fachada, sem fronteira nítida com o id. Embora externamente o Eu aparente ter fronteiras bem definidas, no enamoramento e em outros estados, segundo Freud (1930/2010), a fronteira entre o eu e o objeto (amoroso) é (imaginariamente) rompida. No enamoramento “[...] Eu e Tu são um [...]” (p. 12). Assim, explana que as fronteiras do Eu não são permanentes, seja em estados de enamoramento 
ou em outros estados, e aponta que há uma evolução em relação a esse sentimento do Eu no adulto, diferenciando o princípio do prazer do princípio de realidade, na relação de objeto.

O bebê lactante ainda não separa seu Eu de um mundo exterior, como fonte das sensações que lhe sobrevêm. Aprende a fazê-lo aos poucos, em resposta a estímulos diversos. Deve impressioná-lo muito que várias das fontes de excitação, em que depois reconhecerá órgãos de seu corpo, possam enviar-lhe sensações a qualquer momento, enquanto outras - entre elas a mais desejada, o peito materno - furtam-se temporariamente a ele, e são trazidas apenas por um grito requisitando ajuda. É assim que ao Eu se contrapõe inicialmente um "objeto", como algo que se acha "fora" e somente através de uma ação particular é obrigado a aparecer. Um outro incentivo para que o Eu se desprenda da massa de sensações, para que reconheça um "fora", um mundo exterior, é dado pelas frequentes, variadas, inevitáveis sensações de dor e desprazer que, em sua ilimitada vigência, o princípio do prazer busca eliminar e evitar. Surge a tendência a isolar do Eu tudo o que pode se tornar fonte de tal desprazer, a jogar isso para fora, formando um puro Eu-de-prazer, ao qual se opõe um desconhecido, ameaçador "fora". As fronteiras desse primitivo Eu-de-prazer não podem escapar à retificação mediante a experiência. Algumas coisas a que não se gostaria de renunciar, por darem prazer, não são Eu, são objeto, e alguns tormentos que se pretende expulsar revelam-se como inseparáveis do $\mathrm{Eu}$, de procedência interna. Chega-se ao procedimento que permite, pela orientação intencional da atividade dos sentidos e ação muscular apropriada, distinguir entre o que é interior - pertencente ao Eu - e o que é exterior - oriundo de um mundo externo - e e com isto se dá o primeiro passo para a instauração do princípio da realidade, que deve dominar a evolução posterior. Essa distinção serve, naturalmente, à intenção prática de defenderse das sensações de desprazer percebidas ou das que ameaçam.[...] (Freud, 1930/2010, p. 12-13).

O fundador da Psicanálise aponta que inicialmente o Eu abarca tudo e que depois se diferencia do mundo externo. “[...] Nosso atual sentimento do Eu é, portanto, apenas o vestígio atrofiado de um sentimento muito mais abrangente - sim, todo-abrangente - , que correspondia a uma mais íntima ligação do Eu com o mundo em torno [...]" (Freud, 1930/2010, p. 13). Sendo assim, pode-se supor, segundo o autor, que esse sentimento primário se conservou de algum modo para alguns homens, ilustrando desta forma o sentimento oceânico. Podemos dizer que um movimento de fazer "Um" com o objeto é o que se apresenta no sentimento oceânico e esse movimento é o que escutamos nos sentidos de fusão corpo-máquina (Haraway, 2009; Le Breton, 2003; Lemos, 2010b), que iremos abordar no capítulo seguinte. Sentidos que criam a ilusão de se encontrar a Coisa, "Das Ding", o objeto (inexistente), de um rompimento de barreiras, estas, como dissemos, imaginárias. Apontamos, assim, que formulações discursivas que circulam na pós-modernidade se enlaçam ao eco do sentimento oceânico para se firmarem no campo da oferta de objetos tecnológicos, criando demanda, que, por sua via, modela o desejo aprisionando-o na repetição de se ter ou ser levado a ter cada vez mais objetos 
tecnológicos mais modernos, um gozo com e só com o objeto. Governando as formulações discursivas, está o Mercado, tanto discutido por Payer (2005) como por Braunstein (2010), conforme vimos no capítulo anterior.

O discurso do mercado, como dissemos, sustenta a oferta de objetos que imaginariamente poderiam fazer "Um" com o sujeito, completá-lo, fazer existir a relação sexual, a completude, no sentido do aforisma lacaniano que aponta o avesso, que "a relação sexual não existe" (Lacan, 2003c, 2003e) para dizer do desencontro, da não relação sexual, que pode existir enquanto ação, mas não relação no âmbito de uma complementaridade, do "Um" buscado no mito de Aristófanes, posto que é diferença. Como aponta Lacan (1992, p. 164), “É justamente o que apreendemos no discurso psicanalítico - o Um unificante, o Um-tudo - não é disso que se trata na identificação. A identificação-pivô, a identificação-mor, é o traço unário, é o ser marcado como um". Tal sentido do "Um" retorna o sentimento oceânico sobre o qual Freud (1930/2010) se debruça em "Mal estar" e é diferente do $u m^{12}$ do sujeito, que aponta para a singularidade. Estamos apontando com o aforisma lacaniano uma questão ampla, tomando o sexual como aquilo que movimenta o sujeito na relação com o Outro, com o objeto, e não apenas restrita ao ato sexual, às referências anatômicas. Ousamos, inclusive trabalhar com esse aforisma no que tange à busca pela fusão com o objeto tecnológico de conexão à rede eletrônica posto que o objeto eleito pode ser qualquer. Salientamos, então, que na eleição de um (suposto) objeto de desejo, ocorre que a causa de desejo está presente, porém a causa de desejo não se trata exatamente de um objeto a ser buscado, mas sim, justamente a busca.

Prosseguindo suas análises sobre a relação (sujeito-)eu-objeto, Freud (1930/2010) traz uma importante contribuição para esta pesquisa para tecermos articulações sobre a produção de objetos pelo homem, posto que o homem não só lida com objetos já existentes no meio natural, mas os cria, e, assim, o psicanalista delineia os progressos nas ciências e em sua aplicação na produção de objetos que acarretaram o domínio da natureza de maneira inimaginável em outras épocas. Sobre essas produções, Freud (1930/2010, p. 50-52) aponta que

Vemos como culturais todas as atividades e valores que são úteis para o ser humano, colocando a terra a seu serviço, protegendo-o da violência das forças naturais etc. Sobre esse aspecto do que é cultural não parece haver dúvida. Se voltamos suficientemente atrás no tempo, os primeiros atos culturais foram o uso de instrumentos, o domínio sobre o fogo, a construção de moradias. Entre eles sobressai o domínio do fogo, realização extraordinária e sem precedente; com os outros o homem iniciou caminhos que desde então nunca deixou de

\footnotetext{
12 Torna-se importante enfatizar que esse "um" tem a ver com a singularidade produzida a partir da identificação, tem a ver com o traço unário do sujeito. No capítulo anterior, abordamos com Orlandi (2007a) o "um" que constitui o "Eu sou”, alicerçado por Pêcheux (2009), que vai no mesmo sentido que o "Eu" freudiano.
} 
seguir, e cujo estímulo primordial não é difícil imaginar. Com todos os seus instrumentos ele aperfeiçoa os seus órgãos - tanto motores como sensoriais - ou elimina os obstáculos para o desempenho deles. Os motores lhe colocam à disposição imensas energias, que tal como seus músculos ele pode empregar em qualquer direção; os navios e os aviões não deixam que a água e o ar lhe impeçam a movimentação. Com os óculos ele corrige as falhas da lente de seu olho, com o telescópio enxerga a enormes distâncias, com o microscópio supera as fronteiras da visibilidade, que foram demarcadas pela estrutura de sua retina. Com a câmera fotográfica ele criou um instrumento que guarda as fugidias impressões visuais, o que o disco de gramofone também faz com as igualmente transitórias impressões sonoras; no fundo, os dois são materializações da sua faculdade de lembrar, de sua memória. Com o auxílio do telefone ele ouve bem longe, de distâncias que seriam tidas por inalcançáveis até mesmo em contos de fadas; a escrita é, na sua origem, a linguagem do ausente, e a casa, um sucedâneo do útero materno, a primeira e ainda, provavelmente, a mais ansiada moradia, na qual ele estava seguro e sentia-se bem.

Não apenas parece um conto de fadas; é mesmo o cumprimento de todos os — não, da maioria dos — desejos dos contos, isso que o homem, por meio de sua ciência e técnica, realizou nesta Terra onde ele surgiu primeiramente como um fraco animal, e onde cada indivíduo de sua espécie tem que novamente entrar (oh inch of nature!) como uma desamparada criança de peito. Todo esse patrimônio ele pode reivindicar como aquisição cultural. Há tempos ele havia formado uma concepção ideal de onipotência e onisciência, que corporificou em seus deuses. Atribuiu-lhes tudo o que parecia inatingível para seus desejos - ou que lhe era proibido. Pode-se então dizer que os deuses eram ideais culturais.

Agora ele aproximou-se bastante desse ideal, tornou-se ele próprio quase um deus. Claro que apenas na medida em que os ideais, no julgamento geral dos homens, costumam ser alcançados. Não inteiramente, em alguns pontos de modo algum, em outros somente em parte. O ser humano tornou-se, por assim dizer, uma espécie de deus protético, realmente admirável quando coloca todos os seus órgãos auxiliares; mas estes não cresceram com ele, e ocasionalmente lhe dão ainda muito trabalho. Ele tem o direito de consolarse, porém, com o fato de que essa evolução não terminará justamente no ano da graça de 1930. Épocas futuras trarão novos, inimagináveis progressos nesse âmbito da cultura, aumentarão mais ainda a semelhança com Deus. Mas não devemos esquecer, no interesse de nossa investigação, que o homem de hoje não se sente feliz com esta semelhança.

Pinçamos dessa citação, o processo de produção de objetos pelo homem, a partir do domínio do fogo, e seu desenrolar ao longo da história, e, sobretudo, com o avançar das ciências, como bem apontou o criador da psicanálise. Tais objetos, conforme pressupõe, são voltados para o aprimoramento/aperfeiçoamento dos órgãos, e são concebidos por Freud (1930/2010) como "órgãos auxiliares". Podemos dizer que o pensador austríaco desde o início faz questão de demarcar a não fusão, a não completude, ainda que objetos sejam criados para aprimorar/aperfeiçoar os órgãos, o corpo que o sujeito tem.

Freud não viveu na era dos objetos tecnológicos de conexão à rede eletrônica, mas a avistou de alguma forma. Na pós-modernidade, nos "relacionamos" com objetos tecnológicos 
de conexão à rede eletrônica que são apresentados pelo mercado em formatos cada vez menores, mais acoplados ao corpo, ditos com mais potência, e que mobilizam cada vez mais, não só os contos de fadas, mas os sonhos da ficção científica. A rede eletrônica é dita como aquela que tudo pode ofertar, nela tudo pode ser encontrado. O sujeito, dito navegador, é aquele que está supostamente autorizado a circular pela infomaré e está em todos os lugares sem sair do lugar. São objetos, então, que ofertam pernas compridas, olhos e ouvidos aguçados para que o sujeito tudo encontre, tudo veja, tudo saiba, se, conectar-se ao objeto, cada vez mais incorporado. Apontamos, então, que se na época de Freud escutamos o homem se valendo de suas relações com os objetos tecnológicos no âmbito de uma relação protética, atualmente escutamos sentidos sobre o homem e a máquina na qualidade de uma indefinição de onde começa o homem e onde começa a máquina (Le Breton, 2003; Lemos, 2010b), o que vai ao encontro do "sentimento oceânico" (Freud, 1930/2010), até pela via da metáfora da navegação, do juntar-se ao mundo, pecorrer grandes distâncias, fazer "Um" com outros navegadores, com o mar, o além-mar. Além do princípio do prazer, pois o movimento é no virtual, o corpo do navegador mantém-se como que inanimado diante da tela, o tal retorno ao inanimado do qual disse Freud (1920/1996a).

Lacan (1992), por sua via, faz uma leitura sobre os produtos da ciência, os gadgets, e os nomeia como "latusas" ou ainda pequenos objetos a espalhados pelas vitrines, objetos governados pela ciência com o objetivo de causar o desejo, mas manter o sujeito no gozo, como apontamos anteriormente, um gozo que necessariamente passa pelo objeto, não qualquer objeto, nesse caso, o(s) objeto(s) tecnológico(s) de conexão à rede eletrônica, objetos que fazem semblante de objeto $a$, já que não há representação para este. No contexto pós-moderno, diferentemente de Freud, que viveu na modernidade, o releitor freudiano anuncia que "[...] A latusa não tem razão alguma para se limitar em sua multiplicação. O importante é saber o que acontece quando a gente entra verdadeiramente em relação com a latusa como tal" (Lacan, 1992, p. 172). Aponta ainda que há vento na latusa, e podemos dizer que Lacan faz uma provocação dizendo que há nada na latusa, espaço ocupado por vento. O que se busca não está ali. Acrescenta que é impossível ocupar a posição da latusa, o que podemos dizer que é impossível a fusão com o objeto, a não ser na criação de discursos sobre fusão. No discurso é possível. A palavra sustenta algo, mas não a Coisa, como pudemos articular com Authier-Revuz (2010). Na impossibilidade de se ocupar essa posição - de latusa -, segundo o pensador francês, o que ganha destaque são os sentidos sobre a impotência, e pela nossa escuta, um jogo se estabelece entre potência e impotência na relação com os objetos tecnológicos de conexão à rede eletrônica, ponto de onde partimos nessa tese. 
No campo discursivo, no campo delineado por Pêcheux, podemos também abordar o objeto, o qual, ele apresenta como "condições verbais de existência". Trazemos, então, um recorte de Zoppi-Fontana (2013, p. 4, tradução nossa) do texto "Metáfora de Interdiscurso" de Pêcheux (2011g).

\begin{abstract}
Nosso empreendimento supõe, em minha opinião, levar a sério a noção de materialidade discursiva como nível de existência sócio-histórica, que não coincide nem com a língua, nem com a literatura, nem sequer com as "mentalidades" de uma época, mas que remete às condições verbais de existência dos objetos (científicos, estéticos, ideológicos...) em uma conjuntura histórica dada [...] Trata-se de considerar que as formas discursivas nas quais aparecem os "objetos" [...] são sempre conjunturalmente determinadas como objetos ideológicos: nem universais históricos nem puros efeitos ideológicos de classe. Estes objetos teriam a propriedade de ser ao mesmo tempo idênticos a si mesmos e diferentes deles mesmo, isto é, eles existem como unidade dividida suscetível de inscrever-se em um ou outro efeito conjuntural politicamente sobredeterminado [...] isto supõe que não há, inicialmente, uma estrutura semântica do objeto e em seguida diversas aplicações desta estrutura em uma ou outra situação; assume-se que a referência discursiva do objeto é construída no interior de formações discursivas (técnicas, morais, políticas, etc...) que combinam seus efeitos com os efeitos do interdiscurso (Michel Pêcheux, "Metáfora e discurso", em Análise de discurso: Michel Pêcheux, organizado por Eni Orlandi; Campinas: Pontes, 2011; 151-158, nossa tradução) $)^{13}$.
\end{abstract}

Assim, podemos dizer que o campo do objeto na psicanálise, principalmente no que tange ao conceito de objeto $a$, converge com o que Pêcheux (2011) aponta sobre a materialidade discursiva sobre o objeto. Esse é existente sustentado por formações discursivas. Torna-se importante ressaltar que Pêcheux aponta que os objetos são determinados como objetos ideológicos, idênticos a si mesmo e diferentes de si mesmo, ao mesmo tempo, constituindo uma unidade dividida. Retomando Lacan (1998), podemos dizer que a latusa guarda o vento, o vento da ideologia que determina sentidos sobre os objetos, a serviço do discurso do mercado (Braunstein, 2010), do poder do Mercado (Payer, 2005) e também da ciência, e tenta preencher

\footnotetext{
${ }^{13}$ Nuestro emprendimiento supone, en mi opinión, tomar en serio la noción de materialidade discursiva como nivel de existencia socio-histórica, que no coincide ni con la lengua, ni con la literatura, ni siquiera con las "mentalidades" de una época, sino que remite a las condiciones verbales de existencia de los objetos (científicos, estéticos, ideológicos...) en una coyuntura histórica dada [...] Se trata de considerar que las formas discursivas en las cuales aparecen los "objetos" [...] son siempre coyunturalmente determinadas como objetos ideológicos: ni universales históricos ni puros efectos ideológicos de clase. Estos objetos tendrían la propiedad de ser al mismo tiempo idénticos a sí mismos y diferentes de ellos mismos, es decir, ellos existen como unidad dividida, susceptible de inscribirse en uno u otro efecto coyuntural políticamente sobredeterminado [...] Esto supone que no hay, inicialmente, una estructura sémica del objeto y em seguida diversas aplicaciones de esta estructura en una u otra situación; se asume que la referencia discursiva del objeto es construida en el interior de formaciones discursivas (técnicas, morales, políticas, etc...) que combinan sus efectos con los efectos del interdiscurso (Michel Pêcheux, "Metáfora e discurso", en Análise de discurso: Michel Pêcheux, organizado por Eni Orlandi; Campinas: Pontes, 2011; 151-158, nuestra traducción).
} 
um vazio deixado pela fenda do recalque inconsciente, ao mesmo tempo que a esvazia apresentando um novo objeto. Insistimos que a latusa ou os gadgets ou os servomecanismos ou os objetos tecnológicos não são objeto $a$. São materialidades, formações discursivas que contornam os objetos produzidos pela ciência, e os ofertam como se fossem a Coisa. Indicamos ainda que essa oferta é de natureza ideológica e inconsciente, e, embora articulada por eventuais meandros manipulatórios mercadológicos, são efeitos da constutição dos sujeitos e dos sentidos em dadas condições de produção. Em outra época, outros objetos ocuparam o lugar destinado aos objetos tecnológicos de conexão à rede eletrônica. Como Freud (1930/2010) aponta, o objeto pode ser qualquer. Como Lacan (1992) apontou, manejando o discurso do mestre para o discurso capitalista, o discurso é movente, e o objeto a pode ser disposto em qualquer das posições, porém a posição da causa do desejo, está no discurso analítico. O objeto $a$, pela via do discurso, pode assumir diversas formas, dentre elas, o falo, o seio, as fezes, a voz e o olhar, objetos parciais dos quais trataremos no próximo capítulo ao delineramos a noção de corpo para a psicanálise.

Passaremos a apresentar um tanto de sentido sobre os objetos tecnológicos de conexão à rede eletrônica, para delineá-los para além da maneira como são abordados na pósmodernidade pelo poder do Mercado (Payer, 2005). Tomaremos como referência autores da Cibercultura e da Informática, e, sobretudo, autores da Análise do Discurso, posto que não deixaremos de evocar a falta constitutiva também do objeto tecnológico, que é apresentado ideologicamente como na ordem da potência e da impotência.

\subsection{O objeto tecnológico e a rede eletrônica}

Cabe explicarmos o que concebemos como objeto tecnológico e, ainda, a qual objeto tecnológico estamos direcionando nosso olhar e escuta aos discursos que incidem sobre sujeito e corpo. Tomando Freud (1930/2010) como base, podemos dizer que nomeamos objeto tecnológico como qualquer invenção humana que tenha o objetivo de aprimorar, aperfeiçoar os órgãos, tanto motores quanto sensoriais. Recapitulamos também que o fundador da Psicanálise enumerou diversos objetos tecnológicos, objetos que também podemos conceber como motores (avião, automóvel, barco) e como sensoriais (óculos, telescópio, microscópio, câmera fotográfica, gramofone, a própria escrita). 
Abordaremos aqui um objeto tecnológico específico que é aquele que possibilita a conexão com a rede eletrônica, esta composta por redes ditas infinitas, sustentadas pela internet, definida por Castells (2003, p. 13) como “[...] uma rede global de redes de computadores cujo uso é facilitado para o usuário pela www [...]”. Ou seja, trata-se de uma rede que é ramificada e que além de interligar usuários, também sustenta sítios na rede, como, por exemplo, os sites, os blogs, as redes sociais. Dissemos "objeto específico", porém, como Lacan (1992) apontou, abordamos um objeto que se prolifera, e se prolifera em diversos tipos, especificidades, tamanhos, potência, sustentado pelo poder do Mercado (Payer, 2005) e pelo discurso do mercado (Braunstein, 2010), o qual cria um semblante de que o objeto tecnológico de conexão à rede eletrônica, no presente caso, é aquele que responderá ao desejo do sujeito, obliterando de fato a função do objeto $a$ que é pura e simplesmente a causa de desejo - e desejo não de um objeto específico, como temos apresentado.

Esse objeto específico - objeto tecnológico de conexão à rede eletrônica - se desdobra em uma pluralidade de modelos que vão desde o computador até as chamadas "tecnologias vestíveis", aquelas acopladas ao corpo, como é o caso dos óculos e das lentes de contato que estão em fase de aprimoramento para consumo, que prometem conexão à rede eletrônica e também à realidade aumentada, com comandos de voz, toques, e ainda nas versões mais atuais, somente com um piscar de olhos. Podemos dizer que tal objeto específico, tem cada vez mais se acoplado às formas do objeto $a$, formas que abordaremos no próximo capítulo mas que aqui podemos adiantar suas nuances nos objetos parciais já citados: olho e voz. Objetos parciais, que, por serem parciais, movimentam o desejo pela busca, assumindo assim a função de causa do objeto $a$, aquele que é inexistente e que, no engodo, o sujeito o busca acreditando que irá encontrá-lo e que, ao encontrá-lo, completar-se-á.

Sabemos que o objeto tecnológico que contempla a transmissão de informação via redes, e atualmente oferta tantas outras funções, nem sempre se apresentou como é, com tamanho micro, nano, associado a potência macro. Traremos, então, uma breve história do primeiro objeto tecnológico capaz de armazenar quantidade significativa de informação e transmissão, que é o computador Eniac e abordaremos o aprimoramento e a proliferação do computador pessoal com a oferta da rede eletrônica internet, com o campo virtual e as possibilidades por ele ofertadas, como por exemplo, as redes sociais.

De acordo com Lévy (2005, p. 31), os computadores, “[...] calculadoras programáveis capazes de armazenar os programas [...]” surgiram como tal na Inglaterra e Estados Unidos na década de 40 e durante muito tempo foram de uso militar restrito. Conforme o autor, "O primeiro computador, o Eniac dos anos 40, pesava várias toneladas. Ocupava um andar inteiro 
em um grande prédio, e para programá-lo era preciso conectar diretamente os circuitos, por intermédio de cabos, em um painel inspirado nos padrões telefônicos. [...]” (Lévy, 2004, p. 101), conforme a Figura 5, a seguir.

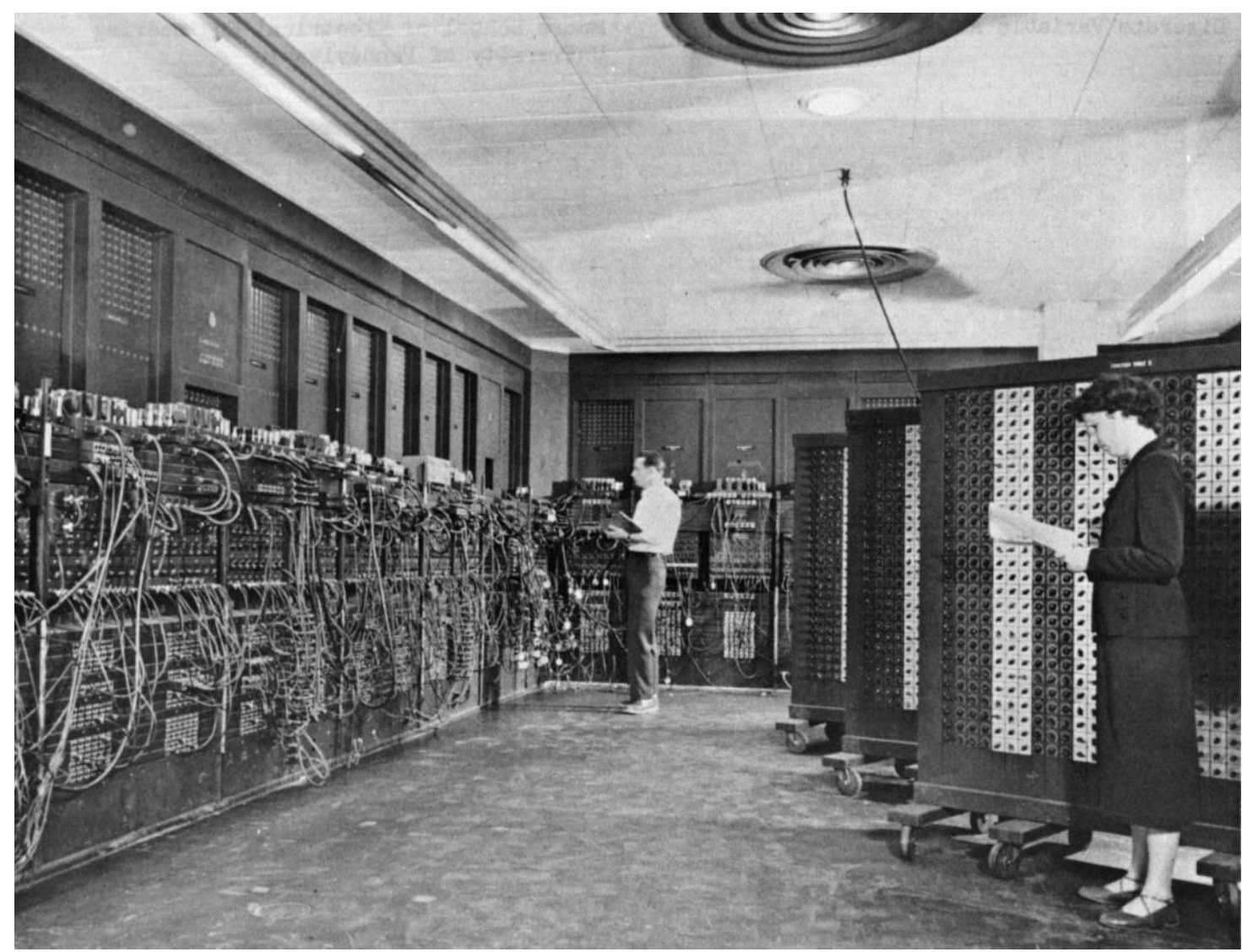

Figura $5^{14}$

Afirma que, a partir dos anos cinquenta, os computadores passaram a ser programados por meio do código binário, através de cartões e fitas perfuradas, e que, embora os cabos ainda existissem, esses foram recolhidos ao interior da máquina, junto a programas e dispositivos de leitura. Neste momento, a máquina começa a ganhar dimensões mais compactas. Segundo o autor, nos anos 70, um movimento social nascido na Califórnia, pautado na "contracultura" criou o computador pessoal, com dimensões residenciais, e segundo Dias (2012), apesar do nascimento da internet ter ocorrido em 1974 com a criação do protocolo TCP/IP, foi na década de 80 que o ideal da contracultura se expandiu mundialmente, assim como o ciberespaço. A partir desse período, “[...] as tecnologias digitais surgiram, então, como a infra-estrutura do ciberespaço, novo espaço de comunicação, sociabilidade, de organização e de transação, mas

\footnotetext{
${ }^{14}$ Recuperado em 16 de dezembro de 2015, de https://aconit.inria.fr/omeka/exhibits/show/histoiremachines/naissance-ordinateur/eniac
} 
também novo mercado da informação e do conhecimento" (p. 32). Nesse espaço de comunicação e sociabilidade, surgiram as comunidades virtuais que atendem a um fluxo de relações interpessoais, movidas pela troca de informação e afetos, e também ao campo do mercado.

Se esse movimento, que abre espaço para as redes, se dá na década de setenta, podemos enfatizar que ele decorre do excesso de visibilidade legitimado a partir da década de sessenta, como bem aponta Debord (2003) com sua ideia de uma sociedade do espetáculo; e como bem aponta Dias (2012, p. 88) ao afirmar que esse excesso de visibilidade da década de sessenta é “[...] que vai criar as condições de produção, pelo efeito de saturação, para uma estrutura de acolhimento no ciberespaço. [...]”. Efeito que é sustentado até nossos dias e que impulsiona cada vez mais a produção de novos objetos tecnológicos que não só clamam a visibilidade, mas se voltam ao acoplamento com os olhos.

Prosseguindo na linha da história, não sem evocar as condições de produção, Dias (2012) afirma que na década de 80 o acesso às redes ainda era restrito ao campo militar e acadêmico, campos nos quais a rede surgiu, assim como o computador; porém, essas redes foram se multiplicando, ao passo que os objetos tecnológicos também foram tornando-se cada vez mais portáteis. Ademais, a rede informacional também foi se voltando cada vez mais para o campo relacional, o campo das redes sociais, de modo que a autora refere que "[...] Rheingold (1996, p. 13) conta em seu livro A comunidade virtual que 'a princípio [lhe] pareceu fria a ideia de uma comunidade apenas acessível através de um écran de computador, mas depressa [constatou] a emoção que o correio eletrônico e as teleconferências [podiam] causar" (Dias, 2012, p. 76), e, complementamos, causam até o momento atual.

Foi já no final da década de noventa que as comunidades virtuais tomaram a forma de redes sociais, as quais se apresentam como espaço privilegiado de sociabilização. Dentre estas redes, ganha destaque atualmente o Facebook, rede social inicialmente voltada para estudantes da Harward, criada em 2004, e que se proliferou, abarcando milhões de conexões pelo mundo virtual e também abarcando milhões de enunciados midiáticos alavancados pelo mercado, rede social que propicia conexões não só entre os usuários que se encontram virtualmente, mas conexão com produtos livremente ofertados no online.

De acordo com Dias (2012), o virtual, presente nos objetos tecnológicos por meio da conexão à rede eletrônica, não é um conceito novo, já que é retratato na pintura, articulado na matemática, na filosofia, na lógica. Mais que um conceito antigo, é uma função que acompanha o sujeito em sua constituição como veremos com Lacan (1998c) naquilo que ele concebe como estádio do espelho. A compreensão das discursividades sobre esse espaço virtual, espaço 
propiciado, no caso, pela rede eletrônica e suas incidências no sujeito e no corpo, interessa a essa pesquisa.

\begin{abstract}
Este espaço virtual que tem sido 'habitado' por todos os setores da sociedade e no qual há um intenso investimento no que se refere à criação de empresas, grupos de discussão, blogs, salas de bate-papo, ambientes de ensino, mundos 3D, enfim, uma série de relações, entre pessoas e entre objetos, que passam a fazer parte das práticas sociais cotidianas. Em função desse espaço virtual, o sujeito contemporâneo mudou hábitos. Ele compra, vende, faz negócios, utiliza serviços públicos, conhece pessoas, produz conhecimento, faz pesquisas, estuda, ensina, seduz, troca correspondência, tudo através da Internet, de ambientes virtuais. As práticas cotidianas se virtualizaram sem que, no entanto, o sujeito saiba o que é o virtual e que efeitos ele produz na sua constituição enquanto sujeito político (Dias, 2012, p. 114).
\end{abstract}

Conforme a autora, o fim do século XX e o século XXI são marcados pela dispersão do virtual e pela globalização, sendo o ciberespaço um grande empreendimento no presente século. A criação das máquinas se voltam para a busca de um comportamento cada vez mais autômato e têm sido transformadas em leitoras de emoções, sendo chamadas de intuitivas. Para Dias (2012), com os computadores pessoais, a navegação em rede, e as novas possibilidades avindas da produção da ciência, os sujeitos se constituem em um espaço-tempo virtual que convoca ao mundo dos simulacros, da imaterialização das relações, e ainda, da desrealização do corpo.

Seguiremos abordando as características do objeto tecnológico que estudamos, o qual, na concepção que estabelecemos para delineá-lo, é composto por rede(s), memória e interfaces. Salientamos que, conforme alerta Romão (2005), na pós-modernidade os autores correm o risco de fazerem uma leitura estritamente técnica do objeto tecnológico de conexão à rede eletrônica, uma leitura que leve em conta apenas a sua formatação, inscrições de hardware e software. No avesso disso, o que apontamos aqui é que trabalhamos com os fios do discurso sobre o objeto tecnológico de conexão à rede eletrônica (que se pluraliza em uma diversidade de tipos, como dissemos), seus pontos nodais e, principalmente, seus furos, sua porosidade. Enfatizamos, assim, que nossa leitura é atravessada por um olhar e uma escuta que concebem esse objeto como aquele que faz de conta que é o objeto $a$, como aquele que é alocado na ordem da potência pelo discurso do mercado, e que nos resta delineá-lo em sua faceta faltante. Assim também faremos com os elementos que o compõem, ou seja, com a concepção de rede, a concepção de memória e a concepção de interface, bem como com a realidade aumentada - nova possibilidade ofertada pelas chamadas tecnologias vestíveis.

Nesse momento, trabalharemos com uma noção de rede, que nos ampara em nossa leitura a respeito da rede eletrônica e do que ela oferta ao sujeito navegador e ao corpo. Isso 
porque, como dissemos, não realizaremos uma leitura meramente técnica do objeto simbólico que elegemos para o nosso estudo. Iniciaremos, então, com a definição de rede, passaremos a abordar a rede discursiva, a noção de hipertexto e teceremos alguns gestos de interpretação aos efeitos de sentido de completude que a rede eletrônica evoca, perpassando ainda a rede social Facebook. De acordo com Romão (2004), “Os trabalhos de Castells (2002, 2003), Cebrián (1999) e Levy $(1993,1996)$ atestam que os termos sociedade em rede, rede de informação e rede internet compõem a manhã do século XXI. [...]” (p. 72), e trazem enfim questões sobre a rede, mas não necessariamente consideram o sistema que realçaremos: aquele composto por nós, fios e furos.

Segundo Musso (2010), a ideia de rede existe desde a mitologia, configurada na imagem da tecelagem e do labirinto. Na Antiguidade comparece na medicina de Hipócrates designando as veias e artérias do organismo. No século XII, segundo esse autor, a palavra aparece na língua francesa representando redes de caça, de pesca e tecidos que revestem o corpo. Posteriormente surge o termo renda para designar tecido e também é utilizado por Descartes para descrever a superfície cerebral. O médico italiano Malpighi descreve a rede reticular da pele. No século XVIII, a matemática se dedica ao estudo da rede numa ordem formalizável. Assim, a palavra nomeia tanto o organismo quanto objetos compostos por fios, nós e furos, e ainda objetos imateriais, representativos, virtuais, que mapeiam o espaço, com linhas imaginárias.

De acordo com Kastrup (2010), o conceito de rede deriva da topologia e não da geometria por ela apresentar geometria variável. Conforme essa autora, o único elemento constitutivo da rede é o nó. Ela pode ser aumentada ou diminuída sem que perca sua característica de rede pois não é definida por sua forma, seus limites extremos, mas sim por suas conexões, pontos de convergência, bifurcações. A rede então nomeia as redes ferroviárias, aéreas, rodoviárias, marítimas, neurais, informáticas, e não “[...] pode ser caracterizada como uma totalidade fechada, dotada de superfície e contorno definido, mas sim como um todo aberto, sempre capaz de crescer através de seus nós, por todos os lados e em todas as direções" (p. 80).

Nesse sentido, a rede eletrônica suporta com seus nós, várias redes, e abre espaço para outras redes se configurarem como as redes sociais, em sua extensão. Na definição de sua extensão pela via de seus nós, a rede eletrônica é discursivizada na pós-modernidade como uma grande rede que tudo contempla e a todos acolhe, em sua dimensão supostamente incalculável. Nessa ordem, ela é tomada como campo da infinitude, e é dita ofertar ao homem que a ela se enoda, a extensão e potência de todo seu corpo: o alongamento de suas pernas e braços, a potencialização de sua visão, voz e audição, podendo assim percorrer espaços antes 
inalcançáveis - ou alcançáveis na ficção, nos contos de fadas como apontou Freud (1930/2010) - no decorrer de segundos, na fluidez (Bauman, 1998) de um paradoxo, sem sair do lugar.

Essa rede supostamente infinita, extendida por seus nós, por outro lado, é uma rede com a qual trabalharemos a partir da noção de rede discursiva, definida por Leandro Ferreira (2003), sobretudo no que ela aponta sobre os furos. Segundo a autora, para compreendermos a noção de rede discursiva,

[...] é preciso acionar a noção de sistema. Uma rede, e pensemos numa rede mais simples, como a de pesca, é composta de fios, de nós e de furos. Os fios que se encontram e se sustentam nos nós são tão relevantes para o processo de fazer sentido, como os furos, por onde a falta, a falha se deixam escoar. Se não houvesse furos, estaríamos confrontados com a completude do dizer, não havendo espaço para novos e outros sentidos se formarem. A rede, como um sistema, é um todo organizado, mas não fechado, porque tem os furos, e não estável, porque os sentidos podem passar e chegar por essas brechas a cada momento. Diríamos, então, que um discurso seria uma rede e como tal representaria o todo; só que esse todo comporta em si o não-todo, esse sistema abre lugar para o não-sistêmico, o não-representável (p. 44).

Trazemos essa noção de rede pois é com ela que lemos o discurso, é com ela que tecemos sentidos na Análise do Discurso (e também na Psicanálise), e é com ela que lemos a topologia da rede eletrônica, visando a colocar em cena a sua incompletude, por mais semblante de completude que os discursos sobre a "rede" tendam a veicular. Traremos também a definição de hipertexto, advindo dos estudiosos da Cibercultura, que constitui a modalidade interativa da rede eletrônica, que constitui uma interface (termo que defineremos adiante) composta pelos textos, ícones e demais entradas para trocas de informação entre o usuário e as imagens que pululam nas telas dos objetos tecnológicos; isso para traçarmos uma leitura sobre a rede eletrônica, conforme a definição de rede discursiva. Assim, segundo Marcuschi (1999, p. 2122), hipertexto é um termo criado em 1964 por Theodor Holm Nelson

[...] para referir a uma escritura eletrônica não sequencial e não-linear, que se bifurca e permite ao leitor o acesso a um número praticamente ilimitado de outros textos a partir de escolhas locais e sucessivas, em tempo real. Assim o leitor tem condições de definir interativamente o fluxo de sua leitura a partir de assuntos tratados no texto sem se prender a uma sequência fixa ou a tópicos estabelecidos por um autor. Trata-se de uma forma de estruturação textual que faz do leitor simultaneamente co-autor do texto final. O hipertexto se caracteriza, pois, como um processo de escritura/leitura eletrônica multilinearizado, multisequencial e indeterminado, realizado em um novo espaço. 
Romão (2004), no campo discursivo, para discutir a topologia da rede eletrônica e do hipertexto (sua disposição textual e imagética), faz paralelos com a narrativa "Alice no país das maravilhas”, de Lewis Carroll. A autora associa as passagens, portas, fechaduras, as ausências de referências de altura e direção, com os links que se seguem não linearmente, em um vai e vem na rede, onde se encontram encruzilhadas, frestas, passagens que levam a lugares inesperados e onde a saída não é necessariamente almejada, como na narrativa das maravilhas. Desse modo, o imaginário sustentado em torno da rede eletrônica, até pela ênfase em sua extensão, remete aos contos: “Como nos 'buracos do coelho' da narrativa infantil, a fundura do hipertexto é imensurável, posto que os túneis em rede são móveis, desdobráveis e deslocáveis. Infinitos [...]” (p. 73). Romão (2005) também aponta em outra escrita, associações da rede eletrônica com o conto "O Livro de areia", de Jorge Luis Borges. Conto que aborda um livro que, tal qual a areia, não tem princípio ou fim. Rede que também assim se apresenta, cabendo ao leitor traçar sua rota e o momento de se desconectar, desenhando um efeito de início e um efeito de fim.

Assinalamos que, navegando por esses túneis e tocas de coelho ou pelo livro de areia virtual, o internauta pode tecer seu percurso, entretanto, o caminho que percorre não é pura criação sua, há caminhos já demarcados pela rede, ou mais precisamente, pelo hipertexto. Assim, é possível caminhar pelos enodamentos, pelos fios esticados e, ainda, cair no furo de não poder tudo acessar, por exemplo, quando um site é colocado fora do ar. Romão (2004) aponta que o trânsito na rede traz ares de liberdade ao mesmo tempo em que não se consegue ter uma noção do trajeto feito, e aponta que "[...] talvez seja justamente essa mudança na ordem, sequência e organização do caminho, da velocidade, do texto e dos atos de linguagem o que se experimenta na rede eletrônica [...]” (p. 4), diferentemente do modo como se lida com outras materialidades, como, por exemplo, o livro, e que desencadeia sentidos de que tudo é possível no virtual.

Diante dessa rede aberta, da qual não se vê a extensão, Romão (2005) assinala a navegação como uma "[...] possibilidade de os sujeitos inscreverem discursivamente suas fantasias [...]" (p. 2), mudarem de corpo no virtual, mudarem de identidade, podendo falar de um modo descompromissado com a realidade, colocando em cena o personagem que quiserem. Para a autora, o deslocamento no ciberespaço, “[...] cheio de tocas de coelho branco - cria condições para que o sujeito construa a sua discursividade na fugacidade, também marcada pela possibilidade de dizer e escrever, na tela, a fantasia que lhe é interditada na realidade" (p. 6-7).

$\mathrm{Na}$ extensão dessa rede aberta, temos visto se legitimarem as redes sociais, como dissemos na seção anterior. E dentre essas redes, abordaremos o Facebook, que tem enlaçado 
os sujeitos navegadores no movimento de agregar laços denominados de amizade em seu perfil, a compartilhar imagens, sons, textos, a criarem álbuns de fotos e vídeos, a curtirem e comentarem as postagens que cicurlam em sua "página inicial", a cutucarem aqueles com quem se almeja uma interação, a deixar uma mensagem inbox - visível só para aquele a quem se destina a mensagem - a deixar uma mensagem pública, a participar de grupos secretos ou não secretos, a fazer convites para eventos, a jogar jogos online, a comprar dos anúncios que pululam nesta página e que sustentam os nós dessa rede, que se apresenta como uma rede social, de amizade, e que configura-se como uma rede do mercado, que tem valor de mercado, ainda que em queda neste dia, como podemos visualizar na descrição a seguir.

\section{facebook}

\section{Facebook Inc.}

Site

Facebook é um site e serviço de rede social que foi lançado em 4 de fevereiro de 2004, operado e de propriedade privada da Facebook Inc.. Wikipédia

Fundada em: 4 de fevereiro de 2004, Cambridge, Massachusetts, EUA

Preço das acões: FB (NASDAQ) US\$102,22 -2,44 (-2,33\%)

4 de jan 16:00 GMT-5 - Fontes

CEO: Mark Zuckerberg

Sedes: Menlo Park, Califórnia, EUA

Fundadores: Mark Zuckerberg, Dustin Moskovitz, Eduardo Saverin, Andrew McCollum, $\underline{\text { Chris Hughes }}$ Figura $6^{15}$

Nesse "livro de rosto/face", tradução do termo inglês "Facebook", ao sujeito navegador é ofertado um espaço para a foto do seu perfil e uma foto de capa, além dos espaços elencados acima e outros novos que são apresentados ao sujeito navegador pela empresa mantenedora da rede social de tempos em tempos. As fotos postadas no perfil, e também as fotos postadas cotidianamente na "linha do tempo" pelos sujeitos, geralmente mostram "faces" produzidas, compondo imagens que são ofertadas ao olhar do outro/Outro, como vimos com a Figura 3 "Olhem para mim, por favor", as quais podemos associar com o que Payer (2005) abordou sobre a questão do enunciado de "sucesso" suportado pelo poder do Mercado e a identificação do sujeito com a formação discursiva que sustenta esse enunciado, identificando-se ao Sujeito universal.

\footnotetext{
${ }^{15}$ Recuperado em 04 de janeiro de 2016, de https://www.google.com.br/?gws_rd=ssl\#q=facebook
} 
Como apontou a psicanalista Claire Gillie ${ }^{16}$ (Colloque Voix et Psychanalyse - Voix des murs/ Voix d'a-mour, 03 de junho de 2015), o Facebook é um muro, um mural, no qual se posta o que quiser, ou ainda como apontou Romão (2005), o personagem que se quiser (na rede), tratando-se enfim de um perfil, uma faceta. Todavia, nessa faceta, que o sujeito acredita ser uma unidade, ele posta o que quiser contornado pelas possibilidades elencadas pela rede social, possibilidades que incluem também a censura do perfil quando o sujeito posta imagens de nudez, por exemplo. Há, então, sentidos que são autorizados a circular, e há sentidos legitimados nessa rede social que circulam sem que se diga explicitamente, como, por exemplo, as fotos do perfil que repetidamente ofertam a melhor imagem do sujeito-corpo-face. $\mathrm{Na}$ extensão dessa rede que permite a possibilidade de uma rede de amizades sem que necessariamente os usuários de fato mantenham uma amizade, os sentidos autorizados, legitimados, naturalizam-se a ponto do sujeito acreditar que o seu perfil, a faceta exposta é o todo de sua vida, é a suposta coincidência consigo mesmo da qual fala Pêcheux (2009a), marcando uma relação em que, no excesso, todos os momentos devem ser clicados e postados no Facebook para serem compartilhados com o olhar do outro/Outro.

Nessa rede na qual o sujeito supõe fazer "Um" de si, "Um" com o outro, "Um" com a rede, trazemos a Figura 7, a seguir, pinçada na rede Facebook em 30 de outubro de 2015, na qual podemos apontar uma discursivização que incorpora "Facebook" como parte do cérebro, como região cerebral, e, quiçá como rede neural.

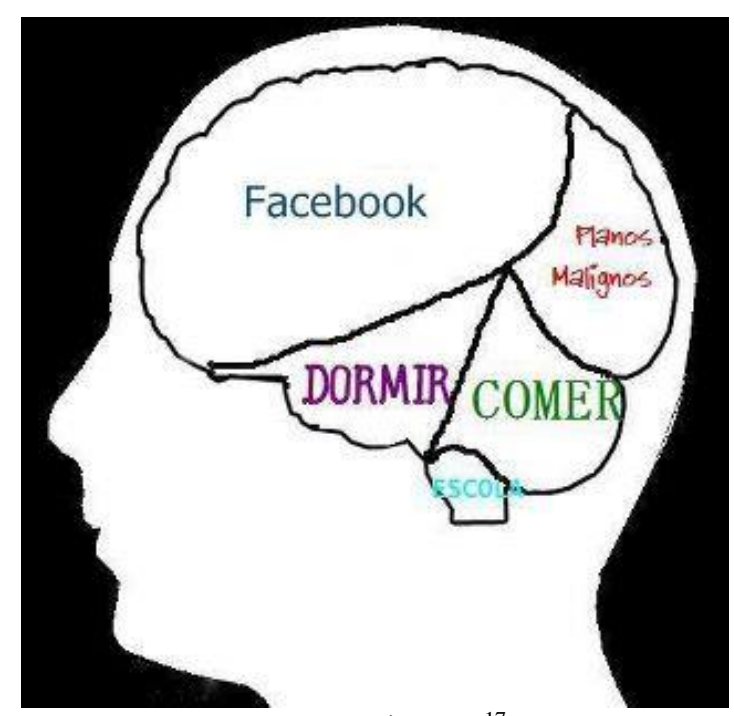

Figura $7^{17}$

\footnotetext{
${ }^{16}$ Seminário proferido no "Colloque Voix et Psychanalyse - Voix des murs/ Voix d'a-mour", realizado no dia 03 de junho de 2015, na Université Paris VII, em Paris.

${ }^{17}$ Recuperado em 30 de outubro de 2015 , de https://lh3.googleusercontent.com/S_OjtEhKHBtr1zZUARFimpPZzmW1rWbLdXvDDXydnOP2JbvhU8jZDW 64JQf8eZ9s7VxtHK4=s87
} 
Nesse enlaçamento de redes (rede social, rede eletrônica, rede neural), o "Facebook", tal qual a "internet”, materializada na Figura 4, apresentada na seção 2.1, são discursivizados ocupando espaço significativo dentre as atividades cotidianas e de "necessidades diárias" de um sujeito-corpo, como "comer", "dormir", "escola" e "planos malignos" (Figura 7) ou ainda “ar", "água”, “comida” (Figura 4). O Facebook, rede social que comparece nas telas dos objetos tecnológicos, na Figura 7, é introjetado no cérebro, correspondendo a uma grande área, ocupando espaço nesse órgão, dito regular o pensamento, e ainda, podemos dizer, comandando certa área do corpo, também a nomeando. Tal introjeção nos leva a pontuar sentidos que circulam em torno da legitimação de se almejar mais, de se pensar mais em "Facebook" e "internet" do que em qualquer outra atividade ou necessidade diária.

Acentuamos, portanto, que a oferta do Facebook ao sujeito, passa da criação da demanda para a necessidade, alocando-o como vital, como da ordem da sobrevivência se comparado a necessidade de água, de comer, de dormir, de respirar. É interessante apontar como que os discursos que circulam sobre a rede eletrônica, sobre as redes sociais, se enlaçam à rede corpórea, seja na convocação à presença do corpo não só colado ao objeto tecnológico ao manejá-lo, mas também colado nas redes sociais como imagem que circula (via fotos, por exemplo), e como nesses discursos comparece a rede (eletrônica, social) incoporada no corpo do sujeito, como se fossem "Um", questão que levantamos sobre o corpo ser convocado à fusão com o objeto.

Retomando o que Romão (2005) apontou sobre a possibilidade dos sujeitos navegadores inscreverem discursivamente suas fantasias na rede eletrônica, e mais, nas redes sociais, podendo construir sua discursividade na tela, trazemos o recorte discursivo a seguir que ilustra como os sujeitos têm legitimadamente se inscrito nesta rede social na busca de olhares, na busca por curtidas, por compartilhamentos, ao inscreverem respostas à questão do Facebook "Em que você está pensando?" na área destinada a postagens dos usuários. Antes de abordarmos a discursividade, acenamos que a referida questão faz laço com a Figura 7, na medida em que o Facebook comparece como área de pensamento na rede neural. Comparece, portanto, regulando o pensamento, regulando sentidos.

Um curta-metragem que faz críticas ao modo como as pessoas usam o Facebook tem chamado atenção justamente nas redes sociais. Intitulado "What's on Your Mind?", o vídeo - que até esta quinta-feira (26) teve cerca de 3,3 milhões de visualizações - tem pouco mais de dois minutos e meio e mostra um homem que leva uma vida monótona e deprimente, mas se esforça para mostrar o contrário no Facebook. 
O curta tem início com o personagem Scott Thomson, vivido pelo ator Espen Alknes, olhando, na tela de seu notebook, posts com fotos de amigos sorridentes, viagens incríveis, um lindo prato de comida e casais felizes.

Ele então lê a pergunta que aparece no Facebook "what's on your mind?" (que, na versão brasileira da rede social, diz "em que você está pensando?") e decide começar a mentir no site, conseguindo um número cada vez maior de "curtidas" em seus posts.

Dirigido pelo norueguês Shaun Higton, o filme já foi finalista do American Pavilion Emerging Filmmakers, em Cannes, e traz a descrição: "O Facebook pode ser deprimente porque as vidas de todos são melhores do que a sua. Mas elas realmente são?" $(26 / 06 / 2014)^{18}$.

Relembremos que, além dos dizeres sobre esse curta metragem, trouxemos na Figura 3 "Olhem para mim, por favor", na seção 1.4, sentidos sobre a visibilidade demandada pelos sujeitos navegadores, que, para serem vistos, colam-se na legitimação de sentidos de "sucesso" ofertados pelo enunciado legitimado pelo poder do Mercado, como apontou Payer (2005). É importante apontar que, embora as visualizações do curta-metragem atinjam milhões, mais especificamente 3,3 milhões de sujeitos navegadores, e que haja postagens que contestem a forma-sujeito que se apresenta como tal na rede social, ela se mantém presentificada, materializada a cada dia, mantendo, assim, a rede como é, como se ali nada faltasse, como se ali a plenitude se realizasse, mantendo-a como objeto suposto preencher a busca do sujeito, que movida pelo desejo, depara-se é com o gozo repetitório, com o objeto, com a rede eletrônica e social. A relação do sujeito-corpo com a rede social acena para o que Freud (1930/2010) aponta sobre o sentimento oceânico, como se na relação com o objeto tecnológico de conexão à rede eletrônica, que permite acesso a rede social, um todo-abrangente fosse conquistado pela imensidão dos nós da rede. Um efeito ilusório, que, impulsionado pelo poder do Mercado (Payer, 2005), disfarça os fios que sustentam financeiramente (ver Figura 6 - "Preço das ações") a grande rede ao fisgar o sujeito que anuncia seu corpo, na rede, e acredita, em parte, que a face é o todo, e que o todo, é encontrável, assim como o objeto (não encontrável).

\footnotetext{
${ }^{18}$ Recuperado em 27 de junho de 2014, de http://cinema.uol.com.br/noticias/redacao/2014/06/26/curta-metragemmostra-como-a-felicidade-pode-ser-forjada-no-facebook.htm
} 


\subsubsection{A memória: a metálica e o Arquivo}

Tendo abordado a rede eletrônica, a rede social e a rede discursiva, seguiremos abordando uma outra rede, de memória, definida no campo da Cibercultura e da Informática em termos de armazenamento e disponibilidade de informação, diferenciando-se consideravelmente da noção de memória tecida por Pêcheux (1999). Assim, no campo da Cibercultura, conforme Lévy (2005, p. 34), “Os suportes de gravação e leitura automáticas de informações são geralmente chamados de 'memória' [...]", e estas configuram-se como “[...] cartões perfurados, fitas magnéticas, discos magnéticos, discos óticos, circuitos eletrônicos, cartões em chips, suportes biológicos etc. [...]” O autor salienta que desde o início da informática, a memória tem evoluído, armazenando mais informação associada a uma miniaturização. Atualmente, um campo de memória que se abre são as chamadas "nuvens", que cada vez suportam mais informações para o sujeito ir e vir sem carregar o peso do papel impresso e sem carregar outras fontes de memória maquínica, bastando uma senha e login para acessá-la, fazendo valer uma modalidade de arquivo de informações. Embora o campo informático enfatize a questão do aprimoramento da memória, com as inovações tecnológicas, a abordaremos de um ponto de vista discursivo, que evidencia a sua estrutura em qualquer dos objetos tecnológicos que a contemplem. Trabalharemos aqui a noção de memória metálica, elaborada por Orlandi (2012, 2007b, 2006) e de Arquivo, elaborada por Romão (2012).

Antes de abordarmos a noção de memória metálica, torna-se importante explanar o que a autora concebe por memória, concepção que segue na linha do que já apontamos sobre a memória para Pêcheux (1999). Então, estudando a questão da interpretação, Orlandi (2007b) faz uma diferenciação entre a memória constitutiva e a memória institucionalizada, esta última constituinte do arquivo, definido por Pêcheux (1997) como campo de documentos pertinentes a uma dada questão. A autora retoma o arquivo e a memória para abordar que a interpretação não é gesto de decodificação, ela é garantida pela memória, ressaltando

[...] dois aspectos: a) a memória institucionalizada, ou seja, o arquivo, o trabalho social da interpretação em que se distingue quem tem e quem não tem direito a ela; e b) a memória constitutiva, ou seja, o interdiscurso, o trabalho histórico da constituição da interpretação (o dizível, o repetível, o saber discursivo) (Orlandi, 2007b, p. 67-68). 
Passamos então pela memória, pelo interdiscurso, pelo arquivo, e Orlandi (2007b, 2008, 2012) nos apresenta o conceito de "memória metálica", fazendo uma diferenciação entre memória histórica, delineada por Pêcheux (1999) e memória metálica, delineada por ela como aquela advinda da informatização dos arquivos. Orlandi (2007b, p. 16) diz que “[...] A memória metálica (formal) 'lineariza', por assim dizer, o interdiscurso, reduzindo o saber discursivo a um pacote de informações, ideologicamente equivalentes [...]”. Essa memória é a inscrita nos objetos tecnológicos, memória que funciona na ordem da repetição, como é o caso da linguagem binária maquínica, movida por combinações de 0 e 1. Assim, ela não é a memória discursiva, nem o interdiscurso, embora estes também sejam permeados pela repetição e pela regularização nos discursos, mas uma repetição e uma regularização que é permeada pelo político, capaz de deslocamento, de acontecimento. A memória metálica é a memória inscrita nas tecnologias, a memória numérica. Para elaborar este conceito, Orlandi (2012a, p. 69) justifica que:

O digital apresentou-se para mim, desde cedo, como uma excelente oportunidade - uma vez que, em geral, se acentua o aspecto tecnológico em sua reflexão, por contar entre as novas tecnologias - para mostrar que não se pode reduzir a questão do digital desligando-a das demais que fazem parte da reflexão sobre qualquer forma de linguagem: memória, ideologia, histórica, subjetividade, individuação, materialidade etc. isso não significa que possamos apenas 'transportar' conceitos e noções e mesmo formas de análise do quadro teórico a que nos dedicamos, mas que essas noções, conceitos, procedimentos são pontos de apoio para interrogarmos a estrutura e funcionamento das novas tecnologias [...].

Orlandi (2007b) afirma que com a informatização, a exterioridade se apresenta como absoluta, desligada de qualquer memória histórica e se abriga em uma formulação alicerçada em uma língua universal, lógico-matemática, sem memória. Ela aponta que a língua da memória histórica, "a língua com falha", que preferimos apontar como faltante já que a ordem da língua é a da falta, em seu funcionamento, produz o possível, e acrescentamos: nos contornos ao impossível. Já a língua, considerada sem falha, a da memória metálica, “[...] e que se apresenta como ilimitada em sua extensão, só produz o mesmo, em sua variação, em suas combinatórias. $[\ldots] "$ (p. 16).

A autora aponta que as formas linguísticas não estruturadas na ordem lógico-matemática são capazes de deslocamentos, de reorganizações, de rupturas, de acontecimento, e, por isso são capazes de política. A língua das máquinas não. Assim, podemos pensar que o que a língua das máquinas pode fazer é dar suporte ao discurso dos sujeitos, ao mesmo tempo em que é o discurso que dá suporte para a criação da língua das máquinas. Desse modo, a rede eletrônica nada diz, ela apenas dá suporte aos discursos e possibilita a circulação destes. São os discursos 
sobre os objetos tecnológicos que dão voz a essa suposta língua ilimitada da máquina, e esses discursos são formulados e postos em circulação por sujeitos, afetados pela ideologia e pelo recalque do inconsciente.

Orlandi (2006, p. 5) aponta que a memória da máquina, produzida pelas novas tecnologias de linguagem (binária) é a memória da circulação, “[...] que não se produz pela historicidade, mas por um construto técnico (televisão, computador etc.). Sua particularidade é ser horizontal, não havendo assim estratificação em seu processo, mas distribuição em série, na forma de adição, acúmulo [...]”. Ela é quantidade e não historicidade. Essa importante definição tem contribuído para diversos autores da Análise do Discurso pensarem a questão da memória diante dos novos objetos tecnológicos, supostos tudo poderem, tudo encontrarem. Dias (2011, p. 30) é uma dessas autoras, e define que:

Se, por um lado, a memória discursiva se constitui pelo esquecimento e a memória de arquivo pelo não esquecimento regulado por uma normatização no processo de significação, conforme aponta Orlandi (2006), a memória metálica se constitui pelo excesso, pela quantidade. Não é uma memória que esquece, nem uma memória que institucionaliza/normatiza para não esquecer, é uma memória que soma, acumula, por isso, numérica.

Mobilizando o conceito de memória metálica de Orlandi (2007b), trazemos uma notícia encontrada no site Olhar Digital, intitulada "Homem mais conectado do mundo usa 700 sensores no dia a dia" e publicada em 31 de março de 2014.

A tecnologia vestível está chegando, e isso aterroriza algumas pessoas, temendo que seus dados mais privados sejam expostos e aproveitados por empresas inescrupulosas. Chris Dancy não é uma dessas pessoas. Ao ver estas novas tecnologias, ele as abraçou como nenhum outro ser humano fez, e acabou merecendo o título de pessoa mais conectada e quantificada do mundo. $\mathrm{O}$ americano de 45 anos não economiza quando o assunto são gadgets dos mais diversos tipos. São 700 dispositivos e sensores utilizados por ele para captar todos os tipos de detalhes e mínimas informações sobre sua existência, saúde, além de sempre ter conectividade com a internet.

Isso já tem impactos diretos em sua vida. Com as informações coletadas pelos seus aparelhos, ele consegue monitorar o quanto ele se movimenta e como ele come. Assim, ele já conseguiu perder 45 quilos.

"É um 'hack' do corpo e da mente. Assim como hackeamos computadores e qualquer tipo de dados, seu corpo e sua mente são os maiores sistemas de informações que a humanidade já conheceu. E entendê-la a torna hackeável", afirma ele ao Daily Mail.

Entre os dispositivos que ele usa para captar seus dados e informações do mundo a sua volta estão o relógio inteligente Pebble, um Google Glass, uma pulseira inteligente da BodyMedia e um monitor cardíaco conectado. E não é só no corpo. Sua casa também é tão conectada quanto a tecnologia moderna permite. O sistema de iluminação utiliza a linha de dispositivos Hue, 
da Philips, que permite o controle por smartphones. Sua cama utiliza o sensor Beddit, que coleta dados sobre como ele dorme.

Seus bichos de estimação também acabam fazendo parte desta onda. Seus dois cães também tem suas atividades monitoradas por meio de um sistema de GPS para animais chamado Tagg.

Ele adquiriu este hábito há cinco anos, quando teve uma revelação. "Eu percebi que eu estava colocando muitas informações online, e se um destes serviços deixasse de funcionar, eu perderia muitos dados relevantes, pelo menos naquele tempo", diz ele. Então ele começou a adotar dois ou três sistemas por semana, e diz que o resultado tem sido benéfico, como a perda de peso já citada, graças à ajuda no controle dos exercícios e dieta. $(31 / 03 / 2014)^{19}$.

Articulando a matéria com o conceito de memória metálica, podemos assinalar como a memória da máquina, dos objetos tecnológicos, é uma memória de acúmulo, da saturação; como a própria reportagem diz, "capta dados e informações” e captura o sujeito na busca pelo controle de um todo-abrangente, na evitação da perda, ou ainda, na tentativa de encontrar o que falta (Lacan, 2005). Nas discursividades mobilizadas na matéria a que nos referimos, a memória é suposta tudo guardar, mas, ainda assim, está sujeita à falha, e ainda, a falhar por ser "hackeável". A própria quantidade de sensores e dispositivos anuncia que é uma memória sujeita a falha, ainda que a ideologia do mercado trabalhe para que os sentidos dominantes sejam de uma eficácia quase inabalável na ordem da guarda de informações mediada pelos objetos tecnológicos.

Assinalamos que nesse recorte discursivo sobressaem-se discursos de completude e de inteireza sobre o sujeito, nomeado como "pessoa mais conectada e quantificada do mundo" ou ainda que "seu corpo e sua mente são os maiores sistemas de informações que a humanidade já conheceu". Esses discursos reafirmam sentidos de um sujeito sempre online por "sempre ter conectividade com a internet", criando efeitos de "controle" e "poder" ao monitorar o corpo, a casa, os bichos de estimação, outros gadgets a partir dos sistemas acoplados no corpo. Todavia, a falha da memória da máquina é discursivizada na suposição de que "se um destes serviços deixasse de funcionar", "perderia muitos dados". Diante dessa possibilidade de falha da máquina, nesta posição-sujeito, a saída encontrada é buscar outro objeto tecnológico que supostamente possa garantir controle e armazenamento de informações, sem perdas. Uma repetição que não desloca, assim como a repetição inerente ao funcionamento da máquina, não capaz de ruptura, de associações, de política. Comparece um sujeito atravessado pela ideologia dominante do Mercado, que oferece sempre um outro produto para aquele que busca um outro

${ }^{19}$ Recuperado em 31 de março de 2014, de http://olhardigital.uol.com.br/noticia/41138/41138. 
produto para suprir aquilo que o objeto anterior não supriu, no caso, em termos de armazenamento e controle de informações. É interessante ainda apontar que, o acúmulo de sensores é tomado como "hábito" e não "vício", "dependência”, como seria nomeado qualquer outro excesso.

A partir desse momento, abordaremos outro conceito importante na Análise do Discurso, o conceito de Arquivo (Romão, 2012) em relação ao arquivo. Romão (2012) tece uma leitura sobre o conceito de arquivo, delineado por Pêcheux (1997), e também leva em consideração as noções de arquivo de Derrida (2001) e de Colombo (1991), para delinear o conceito de Arquivo, sustentado pela rede eletrônica. A autora destaca de Derrida (2001) a reflexão sobre o termo arquivo que designa concomitantemente dois princípios: o começo princípio da natureza - e o comando - princípio da história. Aponta que abarcar o começo e o comando implica considerar uma instância de poder, uma instituição, que seleciona os documentos que dela farão parte, reunindo o que pode e deve ser dito, fazendo laço com o conceito de ideologia de Pêcheux (2009a). O arquivo, para Derrida (2001), deriva de arkhêion, o domicílio dos arcontes, daqueles que detinham o poder político.

Assim, segundo Romão (2012, p. 114), “O efeito de oficialidade desses primeiros arquivos marca o modo como os guardiões prezavam uma localização, ou seja, um lugar de preservação física de documentos e suporte. [...]”. Tal efeito nos lembra o que Pêcheux (1997) aborda sobre o arquivo, os escreventes e os intérpretes, aqueles que cuidam do arquivamento, aqueles que decidem o que será arquivado, aqueles que têm acesso ao arquivo, aqueles que não têm. Lembremos que Orlandi (2006) aponta o arquivo como a memória institucionalizada, aquela que se apresenta como não esquecimento, alocada em instituições que cuidam de mantêla, para alguns.

Romão (2012) aponta a questão política no "arquivo", incluindo o arquivo em rede eletrônica, posto que certos sentidos são mostrados e outros são silenciados, até mesmo pelo efeito do real, do impossível, de tudo dizer e de tudo arquivar. E destaca que

[...] o arquivo é sempre uma parte, um fragmento marcado pela ilusão do todo. Lidar com o não todo e com a incompletude do arquivo faz uma "linkagem" com o que as instituições arquivísticas procuram escamotear, a sua própria condição de falta, a condição insuportável de que há uma ausência constitutiva ao ato de guardar. E não apenas elas creem que tudo pode estar ali reunido, os defensores entusiasmados da rede eletrônica (e aqueles que se filiam ao senso comum igualmente) anunciam que, na Biblioteca de Alexandria da pósmodernidade, cabem tudo e todos. Alguns enunciam um dilúvio informacional capaz de banhar todos com as mesmas águas e os movimentos tempestuosos na trama digital como indiciários de que todas as fronteiras foram abolidas (LEVY, 1999). Com esse olhar, a ilusão de apagamento das contradições está 
posta a produzir efeitos de liberdade para todos de maneira homogênea e igualitária (p. 114-115).

A ilusão de que o arquivo tudo guarda, deságua para as águas cibernéticas que não alocam documentos e informações em instituições de concreto, e criam ares de fluidez (Bauman, 1998) pela suposta não existência de barragens, de barreiras "físicas" na rede eletrônica. Romão (2012, p. 115) assinala que o "[...] desejo de guardar (supostamente) tudo e de tudo ter sob controle e comando inscreve-se na atualidade, fazendo retornar o imperativo da potência e o (desejado) tamponamento de furos e faltas do/no arquivo [...]”, conforme pudemos ler com a notícia sobre o homem "mais conectado do mundo" que utiliza centenas de sensores para armazenar informações, para se relacionar com o "mundo a sua volta", enviando comandos, numa relação que evoca o sentimento oceânico que mencionamos com Freud (1930/2010), sentimento de completude, todavia movido pela tensão constante da perda (de informações). Na relação com o objeto tecnológico e sua rede de memória, pulsa no sujeito o movimento de tentar acreditar que todas as informações estão salvas, que o objeto/arquivo será sempre encontrado.

Com os objetos tecnológicos, a referida autora afirma que esse efeito foi potencializado pelo mecanismo ideológico que sustenta que todos estão online o tempo todo, podendo acessar todos os arquivos eletrônicos, inserindo um fluxo do poder-dizer/acessar sem limites, já que a rede eletrônica oferta a possibilidade do sujeito-navegador ampliar o arquivo pelo qual navega e criar arquivos na rede. Entretanto, o Arquivo, como delineado por Romão (2011) é circunscrito "[...] como lugar discursivo nunca acessável formado pela soma de todos os arquivos interconectados. Tal enodamento [...] no arquivo torna-o mais potente e menos implicado pela ausência do que ali não está [...]" (Romão, 2012, p. 115). Essa "promessa de plenitude" condensa o desejo de retorno à origem abordado por Derrida (2001), “[...] de montagem a um todo que é inacessível ao humano" (Romão, 2012, p. 116) e que associamos a busca do humano pelo objeto supostamente perdido, trabalhado por Freud (1930/2010) e Lacan (1995), como vimos na seção 2.1 .

Romão (2012) destaca de Colombo (1991) a ênfase tecnológica na memória arquivística, criando cada vez mais objetos tecnológicos com a função de registrar e condensar dados, cada vez mais portáteis e potentes - como é o caso dos óculos e das lentes de contato que prometem conexão à rede eletrônica -, e cada vez mais para não perder, para ter todos os dados em mãos. Nesse sentido do arquivamento, atualmente, também estão a disposição as "nuvens", tecnologia que não vemos e não tocamos, que não precisamos carregar, e que podemos acessar, 
como dissemos, bastando uma senha e um login. "Isso tem relação com o arquivo na medida em que inscreve um modo diferente de lidar com os efeitos de guarda e permanência que, [...] estavam ligados a uma localidade fixa e a um ordenamento legitimado por pessoas autorizadas a fazê-lo" (Romão, 2012, p. 117). Tais efeitos têm a ver com o tempo e o espaço, a instantaneidade e o não deslocamento físico.

Na moldura das atuais condições de produção, os arquivos contemporâneos entendidos ao modo de que Pêcheux (1997) chamou de campo de documentos sobre uma dada questão - vendem a imagem de totalidade e completude e mantêm a ausência e a falta fora do seu seio de dizer, afastadas como impossíveis de serem tateadas. [...]; ao mesmo tempo produz-se um silenciamento da perda, do esquecimento, do que escapou ou do que não foi possível abarcar, efeitos incômodos de/para dizer em tempos de plenitude e potência. Em relação ao digital, isso se complica e, colocando justamente aí a minha pena, proponho pensar a internet como um espaço discursivo, no qual o Arquivo (ROMÃO; BENEDETTI, 2008) é inacessível e inacessável, já que ele compreende a malha de pequenos arquivos conectados sem uma dimensão de fisicalidade e com veios de ligação imprevisíveis entre si (Romão, 2012, p. 117).

A autora prossegue assinalando que não só a extensão do Arquivo é escondida, mas também a sua fragilidade, pela própria impossibilidade de abordagem de seus contornos e limites, e lembra o que Pêcheux (1997) aborda sobre as "clivagens subterrâneas" nas diferentes maneiras de se ler o arquivo, apontando que, hoje, está nas mãos de técnicos de informática a leitura da arquitetura da rede. Assim, o sujeito-navegador acredita tudo acessar, pelo efeito ideológico do tudo poder, sustentado pelos discursos em torno dos novos objetos tecnológicos, enquanto percorre por caminhos autorizados a circular: páginas estão online e em outro momento desaparecem, caminhos são traçados pelo dispositivo de busca do Google de acordo com o acesso em determinado IP, sendo necessário navegar por vários computadores para encontrar novos dados, ou ainda por outros buscadores.

Ao sujeito é possível mobilizar "seus arquivos" mas não o Arquivo, de domínio dos provedores de internet. Em nossa condição de sujeitos-navegadores-pesquisadores, já que é nestas águas em que nos banhamos, também estamos sujeitos a este caminho já autorizado, pelo digital, mas intentamos traçar leituras a esse Arquivo e ao lugar dos objetos tecnológicos de conexão à rede eletrônica, de modo a trabalharmos com as contradições, com os efeitos ideológicos que incidem nesse domínio. Retomando a notícia pinçada do site Olhar Digital sobre o "Homem mais conectado do mundo" que "usa 700 sensores no dia a dia", podemos pensar no efeito de completude e potência que sustentam os discursos sobre os novos objetos tecnológicos de "começo" e "comando", no efeito que provoca silenciamento do furo. Esse 
efeito é que faz com que se acredite que "Se o Google não acha... não existe" (Figura 8), ainda que se constate o furo do não encontro daquilo que se buscava, "de novo", na ordem de uma repetição que não provoca deslocamento.

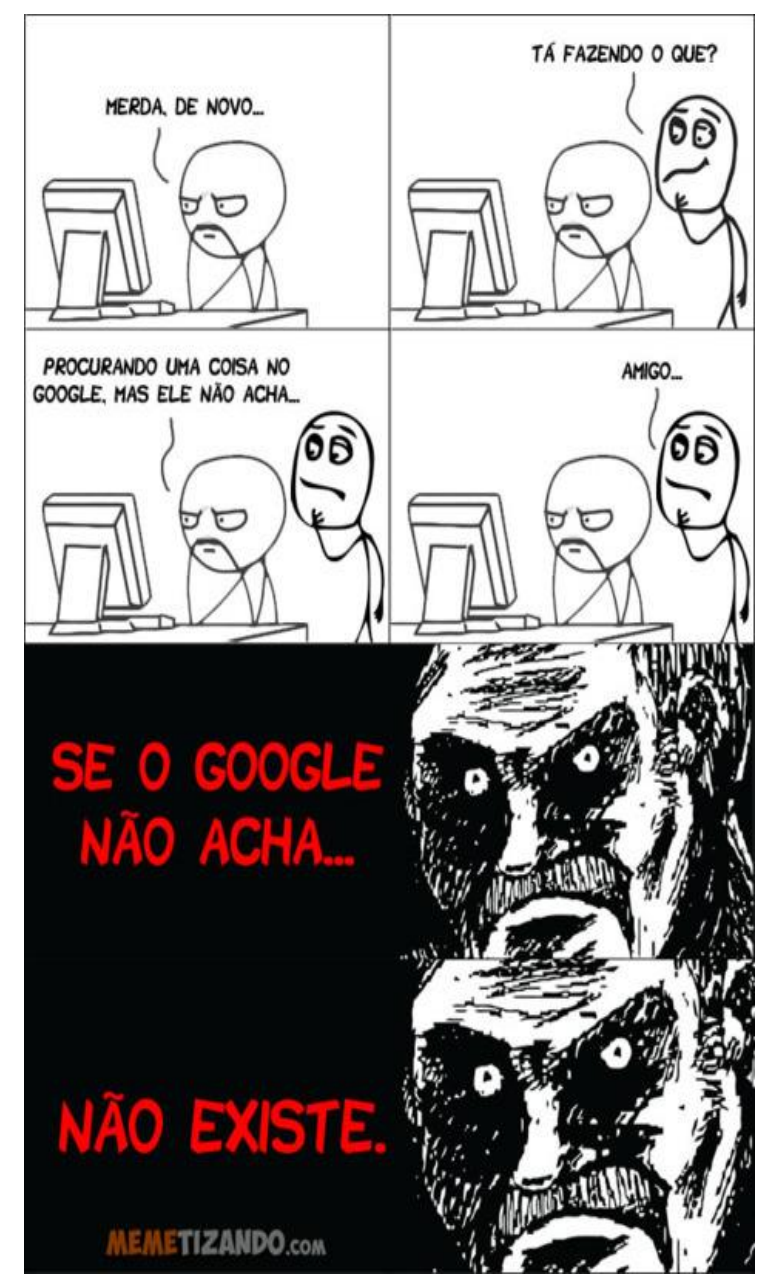

Figura $8^{20}$

Apontando que o Google se constitui como um dispositivo de busca, podemos tecer sentidos sobre a busca do sujeito, esta marcada no campo do imaginário pela busca de um dado objeto, e, mais ainda, a um objeto perdido, como temos apontado com Freud (1930/2010) e Lacan (1995, 2005), ou ainda, contornado pelo simbólico pelo simples movimento da busca, inclusive do ato de pesquisar no qual nos incluímos como sujeitos-pesquisadores, na rede. Trazemos esses apontamentos pois, na enunciação que estamos analisando, o objeto buscado, na rede eletrônica, só não existe se o Google não encontrar. Dizemos, então, dos discursos sobre o dispositivo Google atestarem a existência ou não do objeto procurado, como se no âmbito da

${ }^{20}$ Recuperado em 5 de junho de 2013, de www.memetizando.com> 
rede eletrônica ele pudesse ser supostamente encontrado. E mais, se encontrado, logo existente, se não encontrado, logo, não existente. A questão da existência ainda nos leva a associar, metaforicamente, os discursos que legitimam a existência do sujeito-corpo no virtual, como vimos com a Figura 2, na qual a vida do sujeito é discursivizada na e somente na relação com o objeto tecnológico, como na Figura 3, ofertando o corpo na rede clamando o olhar do outro/Outro, e ainda nas Figuras 1, 4 e 7, na medida em que o cabo de conexão, o Facebook e a internet comparecem introjetados no corpo, criando efeitos de sentido de que o objeto tecnológico e sua potência são vitais ao sujeito-corpo. Tais apontamentos têm a ver com a noção de Arquivo, pois, evocam sentidos de que, conectado ao objeto tecnológico e à memória metálica, sujeito e corpo são potencializados, também em relação ao armazenamento de informações, silenciando a faceta do Arquivo como inacessável e inacessível, conforme aponta Romão (2012).

\subsubsection{As interfaces}

Seguiremos abordando as interfaces, ou seja, os aparatos que possibilitam direta ou indiretamente a interação entre sujeito, corpo e objeto tecnológico de conexão à rede eletrônica, tecendo uma leitura sobre as modalidades dessa interação e da convocação do corpo à conexão, ao acoplamento com a máquina. Temos dedicado escuta a relação sujeito, corpo e objetos tecnológicos de conexão à rede eletrônica e, aqui, apontaremos como essa relação, a qual opacizamos, é tomada na via de uma complementariedade, de um acoplamento na interação com o objeto, que, como veremos, chama o corpo e partes dele a comparecer como interface do objeto.

Conforme Lévy (2005, p. 37) o termo interface designa “[...] todos os aparatos materiais que permitem a interação entre o universo da informação digital e o mundo ordinário. Os dispositivos de entrada capturam e digitalizam a informação para possibilitar os processamentos computacionais [...]”. Assim, tais aparatos materiais, a partir da invenção do computador, abrangem desde cabos, tela, teclado, mouse até sensores que captam movimentos do corpo. Além destes aparatos de hardware, os softwares também são considerados interfaces. Para o referido autor, 
[...] o espectro de ações corporais ou de qualidades físicas que podem ser diretamente captadas por dispositivos computacionais aumentou: teclados que permitem a entrada de textos e o fornecimento de instruções aos computadores, o mouse por meio do qual é possível manipular 'com a mão' as informações na tela, superfícies sensíveis à pressão dos dedos (tela sensível ao toque), digitalizadores automáticos de som (samplers), módulos de software capazes de interpretar a palavra falada, digitalizadores (ou scanners) de imagens e de textos, leitores óticos (de código de barras ou outras informações), sensores automáticos de movimentos do corpo (datagloves ou datasuits), dos olhos, das ondas cerebrais, de influxos nervosos (usados em algumas próteses), sensores de todos os tipos [...] (Lévy, 2005, p. 37).

As mudanças nesses aparatos são sinalizadas por Cebrián (1999, p. 42) que nos aponta substituições que implicam em desaparecimento, como, por exemplo, do mouse, que, segundo ele, “[...] será substituído por pressões táteis sobre a tela antes que se tornem populares as máquinas capazes de executar ordens faladas, inclusive visuais. [...]”. Há 17 anos da escrita deste autor, podemos assinalar essa passagem em que o mouse ainda se faz presente, porém tem sido cada vez menos utilizado mediante as telas touch, e, ainda, mediante a produção de objetos tecnológicos que o dispensam, assim como dispensam o teclado e também a tela, projentando imagens diretamente na retina, captando a movimentação dos olhos e comandos de voz, como no caso dos óculos e das lentes de contato que conectam a rede eletrônica. Deparamo-nos com objetos tecnológicos que cada vez mais destituem aparatos periféricos, na medida em que mais se acoplam ao corpo, aos órgãos do corpo, como os olhos. Como Lacan (1992) apontou, as latusas não têm razão alguma para não se proliferarem, e acrescentamos, a se tornarem cada vez mais acopladas se isso servir à formação discursiva dominante.

Tais mudanças e aprimoramentos foram em parte historicizadas na seção 2.1, mas apresentaremos aqui uma taxinomia estabelecida a partir das formas de interação entre usuários e computadores delineada por John Walker, criador da empresa Autodesk, conforme nos conta Lemos (2010a). O empresário, de acordo com o autor, catalogou cinco gerações de interface, sendo que a primeira delas surgiu na década de 40 com os primeiros computadores, com os quais a interação se dava por meio de cabos e plugs. Nem tela, nem teclado se faziam presentes e se presentificaram algumas décadas depois, assim como estão sendo substituídos no século XXI.

A segunda geração se constituiu, então, na década de 50 quando a interação passou a se dar por meio dos cartões perfurados. Segundo Kirner e Siscoutto (2007), as interfaces computacionais utilizadas nos anos 40 e 50 baseavam-se em chaves e lâmpadas. Conforme vimos com Lévy (2004), nessa década, os cabos que antes eram externos passaram ao interior da máquina, junto com os programas, ao que ele profere: “[...] Aquilo que ontem fora interface 
torna-se órgão interno" (Lévy, 2004, p. 101). Faremos um intervalo para abordarmos essa citação que se torna fundamental para nosso gesto de interpretação às interfaces, incluindo a interface humana.

Por essa afirmação que aponta que a interface, no caso, os cabos, passam a ser "órgão interno", podemos tecer uma leitura que assinala o órgão, componente do corpo, caracterizando o cabo-órgão da máquina, que na via associativa, seria máquina-corpo. Por outro lado, também podemos retomar Freud (1930/2010) quando ele concebe os instrumentos produzidos pelo homem como "órgãos auxiliares", externos ao corpo até então (porque os novos objetos tecnológicos cada vez mais se acoplam e se internalizam no corpo). Assim, vemos ressoar em “cabos, passam a ser órgão interno" e instrumentos como "órgãos auxiliares", a marca de um início de movência na qual os objetos tecnológicos vão adentrando ao interior do "corpo", primeiramente da máquina, e, posteriormente, da superfície do corpo humano ao seu interior (como no caso dos chips ou ainda se tomarmos outras tecnologias como os marcapassos há muito utilizados na medicina). Podemos tomar essa movência inicial como ponto de partida para a Cibercultura se lançar ao estudo do natural e do artificial e da fusão corpo-máquina, na década de 60, como veremos no próximo capítulo.

Feito o intervalo, apontamos que a terceira geração, conforme delineia o empresário na voz de Lemos (2009a), se dá na década de 60 quando entram em cena os teclados e os monitores, permitindo comandos e programações da máquina com maior precisão. Com esses aparatos, apontamos que a relação com o objeto tecnológico passa a possibilitar mais interatividade entre corpo e máquina, embora as interfaces ainda fossem rudimentares (Kirner \& Siscoutto, 2007). A quarta geração é marcada pela utilização de janelas, menus pop up, com as quais o usuário podia selecionar e executar tarefas. A quinta e última geração elencada pelo empresário é apontada como aquela que insere o mouse como modalidade de interação, o qual simula o movimento da mão, esta inclusive representada como desenho na tela ao se movimentar o mouse. A interface da tela também recebe ícones gráficos como pastas, melhor acessados com a interface mouse; geração caracterizada como da manipulação direta da informação.

Conforme Kirner e Siscouto (2007), com a produção de microprocessadores nos anos 70 e 80 , os computadores tornaram-se objetos populares com a interface DOS e posteriormente Windows, que oferecia opções multimídia que persistem até hoje. Entretanto, pela limitação da interface Windows na tela do monitor com ícones e menus, a realidade virtual passou a marcar presença a partir da década de 90 com a utilização de representações tridimensionais, próximas da realidade do usuário. Lemos (2009a) dá continuidade à articulação das gerações e assinala 
que a realidade virtual “[...] é o último passo para a imersão total [...]” (p. 157), através de capacetes, luvas ou roupas de dados com os quais se pode simular uma outra realidade. De acordo com esse autor, "[...] a evolução do diálogo homem-computador vai levar a interatividade a um nível onde as fronteiras parecem ser cada vez menos nítidas” (p. 157). Fronteiras que são assim apontadas pela Cibercultura, e como vimos com Freud (1930/2010), podemos dizer que trabalham em pról de sentidos que se associam a fusão "eu-tu", como "Um" (Lacan, 1992). Fronteiras apagadas à qual se liga o poder do Mercado (Payer, 2005), que tem levado às últimas consequências, junto com a ciência, a produção de objetos tecnológicos constituídos por dimensões físicas pequenas e que abrem espaço a dimensões virtuais amplas, como com as lentes de contato e os óculos que prometem conexão à rede eletrônica, e ademais, prometem acesso à realidade aumentada.

Esta, consiste, conforme Kirner e Siscouto (2007, p. 5) na “[...] sobreposição de objetos e ambientes virtuais com o ambiente físico, através de algum dispositivo tecnológico [...]”. De acordo com os referidos autores, a realidade aumentada tem sido considerada a próxima geração de interface popular pois não necessita de equipamentos especiais tais como monitores, projetores e capacetes como necessita a realidade virtual. A realidade aumentada permite o uso de ações envolvendo a voz, toques, gestos e está sendo usada em áreas que vão desde o entretenimento até experimentos, "[...] constituindo verdadeiros laboratórios de pesquisa. [...]" (p. 6).

Acrescentamos que, embora esses objetos tecnológicos que possibilitam a realidade aumentada estejam disponíveis a uma pequena parcela da população mundial até porque são alvo de pesquisa e aprimoramento, eles têm sido divulgados com frequência na rede eletrônica e nas feiras tecnológicas, como produtos muito promissores. Embora os enunciados do mercado já trabalhem para promover oferta e demanda, os objetos tecnológicos de conexão à rede eletrônica que circulam nas ruas, são, em sua maioria compostos por tela touch, já tornando mouse e teclado obsoletos. Pensando que o primeiro computador Eniac pesava 40 toneladas e os objetos tecnológicos de conexão à rede eletrônica atualmente são, em sua maioria, portáteis e, ademais, acoplados ao corpo, podemos apontar o quanto os gadgets foram acolhidos não só pelo discurso mercadológico como pelos sujeitos, via identificação à formação discursiva dominante. Torna-se importante indicar aqui que as mudanças nas interfaces, clamando cada vez mais o contato direto entre o corpo e a máquina foram se constituindo com o passar do tempo e, sobretudo, com a sustentação de discursos de potência do objeto em sua miniaturização, instantaneidade, capacidade de armazenamento e acesso a informações. 
Lançamos, assim, o apontamento de que tanto os objetos tecnológicos quanto o corpo são emoldurados em discursos de potência.

Passaremos a alguns gestos de interpretação à interface "tela" e a sua destituição física pela tela virtual projetada diretamente na retina, na medida em que os olhos são convocados a ser interface dos objetos tecnológicos óculos e lente de contato que prometem conexão a rede e realidade aumentada. Teceremos uma leitura sobre a tela, especialmente por sua relação com a divisão, com a marcação de um campo e de outro, o campo da "realidade" e o campo virtual, e o que ela evoca em termos da constituição do eu, como veremos com Lacan (1998c) no estádio do espelho, no próximo capítulo. Nesse momento, para abordá-la, traremos considerações de Romão (2006) sobre esse objeto naquilo que evoca em termos de imagens e de memória no percurso do sujeito que se lança na navegação pela rede eletrônica. A autora faz associações da tela do objeto tecnológico com a tela do pintor e ainda com o espelho, utilizando para isso a obra "Cadernos de Lanzarote", de Saramago, por meio da descrição da mão do pintor ao se deitar no tecido branco da tela, ávida por tinta.

\begin{abstract}
"Sobre o cavalete, o pintor colocou uma tela branca. Olha-a como a um espelho. A tela é aquele único espelho que não pode reflectir a imagem do que está diante de si, daquilo que com ele se confronta. A tela só mostrará a imagem do que apenas noutro lugar é encontrável", seguindo esse fragmento de Saramago (1998:508), a tela, em seu silêncio desejante de tinta, não reproduz a realidade nem a reflete exatamente como um espelho. Ela abrigará imagens do que está vivo em outro lugar e se desloca para a tela quando a mão da memória do artista se deitar no tecido virgem. Então, a corrente migratória de imagens, traços, figuras ganha corpo, inscrevendo formas e sentidos no vazio do branco, afetados pela "representação de uma memória", como diz o autor. É a memória que se desenha, ao desenhar, no movimento do artista, o mundo que ele suporia digno de pintar, pois "ao pintar, o pintor não vê o mundo, vê a representação dele na memória que dele tem" (Romão, 2006, p. 303-304).
\end{abstract}

A autora toma essa citação de Saramago e assinala que a tela do objeto tecnológico apagada, no "cavalete da escrivaninha" - e acrescentamos, na palma da mão, (e ainda, na tela que se reflete no olho) - guarda o que "noutro lugar é encontrável" 21 , tanto no sentido da rede de memória que atravessa a navegação do sujeito enquanto interage com os links da rede, os textos, as imagens, (memória metálica) suas buscas, quanto a memória (do arquivo e Arquivo) pelo fato de que o sujeito é afetado no ato da navegação por uma superfície de dados no já-dado

\footnotetext{
${ }^{21}$ Torna-se importante apontar que tal dizer de Saramago remete à rede de memória, tal qual concebida pela psicanálise e também a memória concebida por Pêcheux (1999), que lança o sujeito ao desejo, ao simples relançar do desejo, não necessariamente materializado em um objeto, que em sendo não encontrado, é não encontrável, mas relança a busca, relança a memória.
} 
da rede, circulando por nós já atados por outros, com um semblante de liberdade. Nessa interação com memórias, digamos assim, a tela, tal qual a tela do pintor, convoca a mão do sujeito navegador a imprimir ali o seu gesto, o seu percurso, ofertando-lhe o acesso, criando a demanda pelo objeto e evocando o desejo e o gozo daquele que se fisga no canto da sereia, (nós), os sujeitos sob a égide do Mercado (Payer, 2005) e do discurso do mercado (Braunstein, 2010). Ainda que seja possível a resistência, a interpelação está posta.

A tela apresenta-se como um caleidoscópio de imagens, com as quais o sujeito pode compor, ao ligá-la e navegar pelos links ofertados, pelo arquivo disposto na rede internet, suposta tudo conter, tudo possibilitar ao sujeito que a ela se conecta. Para discutirmos esse leque de possibilidades frente a tela, trazemos um espelho cibernético do qual encontramos notícias por meio de sites brasileiros de divulgação de tecnologias e o buscamos na fonte ${ }^{22}$. Trata-se de um espelho/tela que possibilita a conexão à internet e joga com com-posições sujeito a cada opção/função ofertada, podendo o sujeito se posicionar imaginariamente tão calidoscópio quanto a tela que a ele se apresenta.

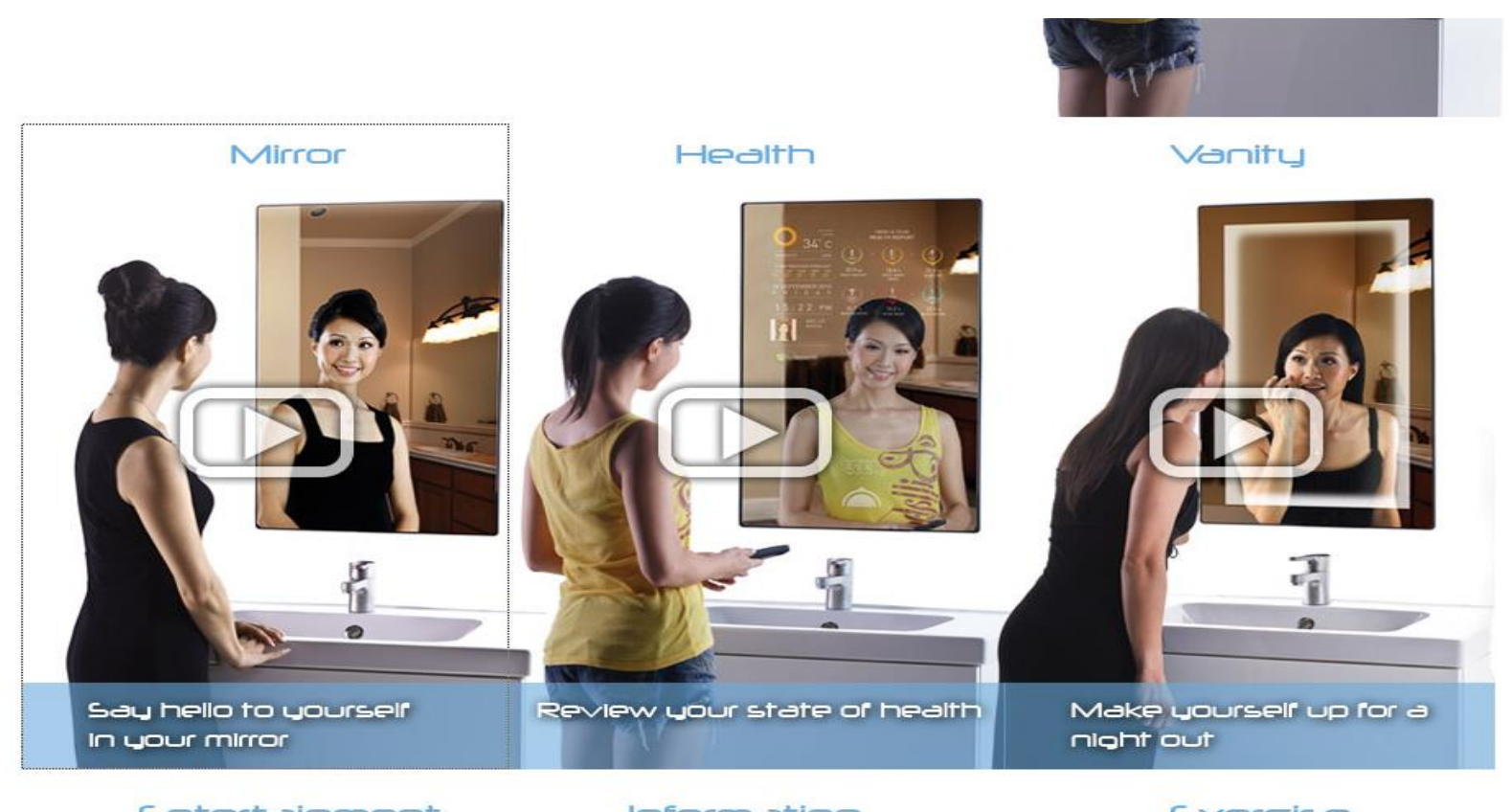

Figura $9^{23}$

\footnotetext{
${ }^{22}$ Recuperado em 18 de outubro de 2012, de http://www.cybertecturemirror.com/main.php?id=features

${ }^{23}$ Recuperado em 18 de outubro de 2012 de http://www.cybertecturemirror.com/main.php?id=features
} 


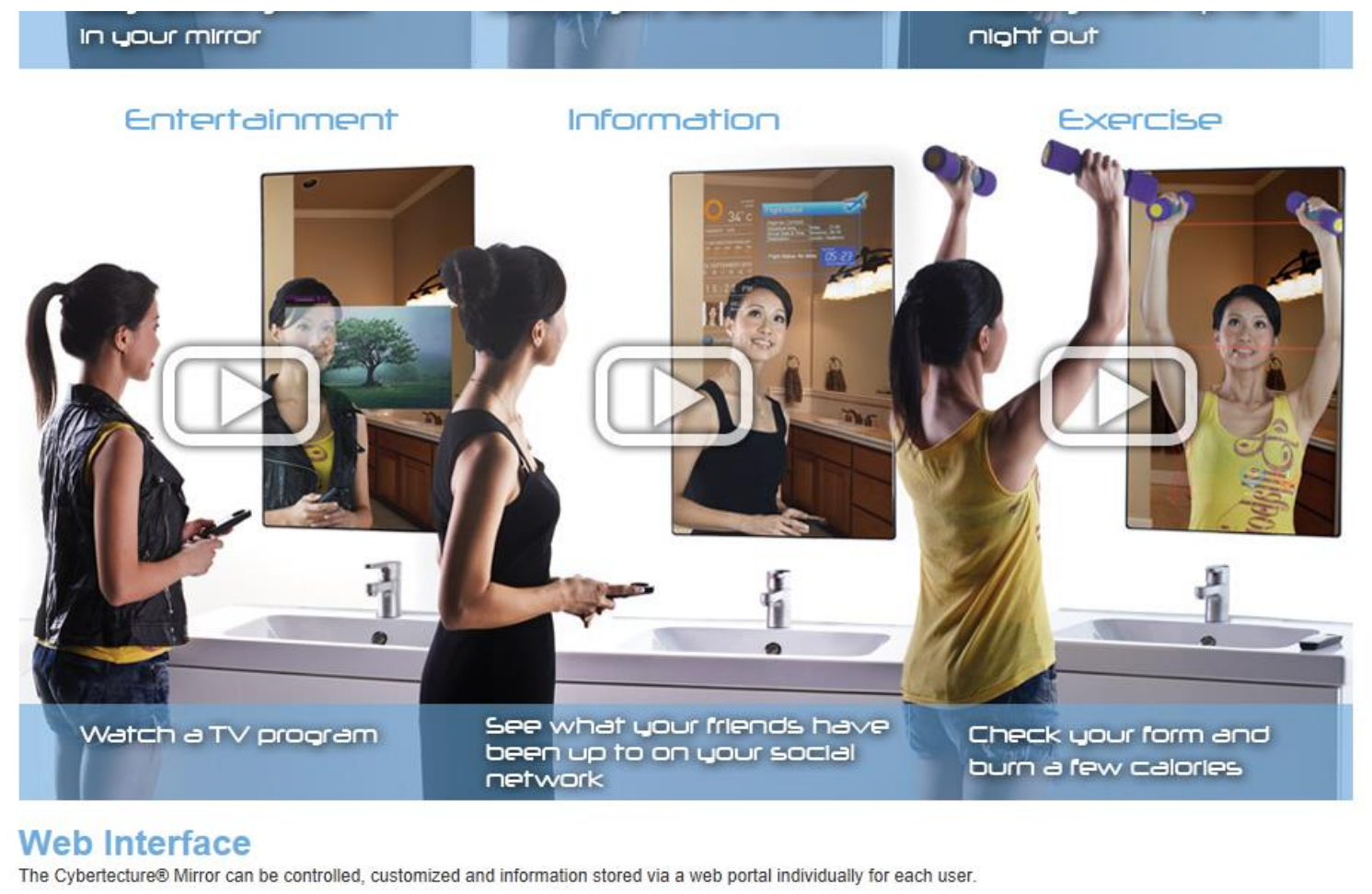

Figura $10^{24}$

Destacamos que a sequência das imagens tais como são apresentadas, evocam uma transformação do corpo - pela mudança de roupa, de penteado, de posição corporal - a cada clique; porém, salientamos que as mudanças se ajustam às opções pré-estabelecidas pelo objeto tecnológico e a rede internet, respectivamente, "espelho", "saúde”, "vaidade", "entretenimento", "exercício". Queremos apontar, com isso, que os efeitos de liberdade inerentes às mudanças corporais, não são quaisquer, são vigorados por aquilo que a tela e a rede ofertam, sendo que o semblante de autonomia do sujeito que interage com o objeto tecnológico, são por elas regrados. Nesse funcionamento, podemos assinalar o processo de interpelaçãoidentificação do sujeito pela ideologia e os efeitos dos esquecimentos que criam a ilusão de autonomia do sujeito, enquanto está assujeitado a formações ideológicas legitimadas em cada condição de produção. Atestando o processo de interpelação-identificação, podemos destacar as formulações discursivas apresentadas imperativamente, na sequência: "Diga olá para você mesmo no seu espelho", "Reveja o seu estado de saúde", "Produza-se para uma noite fora", "Assista a um programa de TV", "Veja o que seus amigos postaram em sua rede social", "Cheque sua forma e queime algumas calorias".

Assujeitado ao imperativo - e aí podemos associar o imperativo do poder do Mercado (Payer, 2005) e do discurso do mercado (Braunstein, 2010) -, o sujeito se enlaça em com-

\footnotetext{
${ }^{24}$ Recuperado em 18 de outubro de 2012 de http://www.cybertecturemirror.com/main.php?id=features
} 
posições sujeito, que, se aparentam ser diferentes pelo fato do corpo se apresentar de outro modo em cada opção, trata-se da mesma posição-sujeito, que se identifica a formação discursiva governada pelo poder do Mercado (Payer, 2005), produzindo discursos efeitos do consumo. Assinalamos ainda, como o discurso que sustenta a oferta do objeto tecnológico espelho cibernético se vale de efeitos imaginários no corpo, advindos do comando do usuário por meio do (seu) corpo que clica, que toca a tela, que a aciona por meio de um controle remoto, e por este ato, muda de corpo, como num passe de mágica, na relação com o objeto.

Traremos nesse momento para tecermos uma leitura ainda sobre a tela e sobre o corpo, o fragmento de um artigo denominado "Geração Touch", publicado no site Infoabril, no qual se aborda as tecnologias touch, que dispensam outros aparatos (como mouses e controles remotos) na conexão com a rede eletrônica, e clama algumas partes do corpo para a conexão, como, no caso, os dedos.

O mundo na ponta dos dedos. Suas decisões nas pontas dos dedos. Dedos indicando cada detalhe dos caminhos de trajeto, informação, consumo ou diversão que você desejar. [...]

Outro dia eu estava conversando em um café com minha esposa. Ela olha para nosso filho de 3 anos, que apoiado num pufe deslizava seus dedinhos num iPad, e me diz: Geração Touch. Esta cena foi decisiva para uma série de discussões com as pessoas na empresa, amigos da vida pessoal, e uma cadeia de gente que encontrei observando cenas similares, desde que os dedos movimentaram-se freneticamente a disparar SMS's. A evolução mobile da tecnologia minimizou chips mas principalmente contextualizou os dedos como link da interface humana [...] Na minha mente veio uma imagem de dedos com músculos em uma mutação futura da espécie. Poderá ser na extremidade da anatomia humana o campo de estimulo da mente.

Poupudas fichas do setor mobile, quer seja através de smartphones ou tablet, estão neste instante depositadas na casa dos aplicativos como motivo central para que os dedos não parem de ser pressionados, nesta vasta imensidão de possibilidades. [...]. É este ecossistema quem se candidata a ser o combustível para que os dedos deslizem cada vez mais nas telas e validem a teoria de uma geração touch dominante.

[...]

"A Criação de Adão" afresco pintado por Michelangelo no teto da Capela Sistina indicou-nos por 5 séculos, através da cena do Livro do Gênesis onde Deus cria o primeiro homem, Adão, o caminho do touch para o renascimento de um novo contato de oportunidades. E agora parece que estamos sendo convidados a sermos "deus" destas oportunidades de novas criações. [...]. $(01 / 07 / 2011)^{25}$.

25 Recuperado em 30 de agosto de 2011, de http://info.abril.com.br/noticias/rede/startup-in/vidadigital/geracao-touch-tablet-mobile/. 
Vimos com Lévy (2005) que o termo interface se refere aos aparatos materiais que permitem a interação com o universo digital, e esses aparatos foram elencados em termos de periféricos; já no recorte que apresentamos, o termo "interface" é deslocado para se referir aos “dedos", às suas funções em relação aos objetos tecnológicos "touch", que são aqueles que contém sensores na tela, que são capazes de identificar toques como comandos. Apontamos que no processo de produção de sentidos materializado na formulação discursiva citada, "os dedos", discursivizados como "link da interface humana", sustentam que no campo do humano há interface. Essa formulação pode estar associada ao fato de que se os dedos deslocam os mouses, os controles remotos, os teclados, nessa série, eles se tornam discursivamente também um aparato, a partir das novas possibilidades que as telas "touch" ofertam.

Nas novas possibilidades ofertadas pelos objetos tecnológicos, podemos dizer que há um empuxo ao corpo para um contato cada vez mais colado ao objeto, sendo o corpo inclusive convocado a sustitutir partes que antes eram constitutivas dos objetos (como dissemos, mouses, teclados etc). No caso, podemos dizer de um empuxo no qual os "dedos" são convocados a um colamento que desliza na tela touch. Aos dedos, na formulação discursiva com a qual trabalhamos, ou mais precisamente, às pontas dos dedos, são atreladas “decisões”, movimentos frenéticos na interação com a tela, cena repetitória que interpela também e sobremaneira os dedos das crianças, cena que de tão repetitória leva ao sujeito a fantasiar uma "mutação futura da espécie”, donde advirão “dedos com músculos”.

À essa descrição, podemos assinalar efeitos antecipatórios de naturalização de uma prática, atrelada à evolução, e ainda a uma "Geração Touch", que, conforme o recorte discursivo, é validada por "poupudas fichas" investidas para que os "dedos" não parem de ser pressionados, nesta vasta imensidão de possibilidades. Assim, podemos afirmar que, no processo de produção de sentidos no qual os dedos comparecem como interface humana na relação com a tela touch, na medida em que os dedos deslizam e se fisgam pela tela, e ainda mais, pela leveza do objeto tecnológico que pode ser manuseado em qualquer lugar (bem diferente do primeiro computador, o Eniac), está o discurso do mercado (Braunstein, 2010) e o poder do Mercado (Payer, 2005) pela via das "poupudas fichas”, tecendo a naturalização do acoplamento corpo-máquina, discurso muito presente na Cibercultura.

Retomando Freud (1930/2010) e o que ele aponta sobre a relação do homem com os objetos da ciência, alocados como "órgãos auxiliares", como aprimoramento do corpo, podemos apontar, na discursividade que recortamos, os dedos sendo convocados como "órgãos auxiliares" do objeto tecnológico/tela. Ou seja, uma inversão. Isso podemos enfatizar a partir também do que Lévy (2004) assinalou quanto a partes da máquina passarem a compor “órgãos 
internos da máquina. Posicionados como interface, os "dedos" então seriam como órgãos externos e, ainda, auxiliares da máquina (do mercado/consumo)?

Apontamos ainda que o sujeito discursivo posicionado como convidado a ser "deus" (e aqui rememoramos Freud (1930/2010) nomeando o homem como "deus de prótese", diante de suas criações), no recorte que estamos analisando, se enlaça à criação com ares divinos, ares de onipotência, onisciência e onipresença, que deslizam para "os dedos", uma parte do corpo, discursivizada na ordem de uma potência (por exemplo, a formulação discursiva: "poderá ser na extremidade da anatomia humana o campo de estimulo da mente."). Por outro lado, se os “dedos" são discursivizados no campo de um poder na tecnologia "touch", com as "tecnologias vestíveis" eles têm sido destituídos, assim como os mouses, os teclados, os controles remotos. Na linha da miniaturização dos objetos tecnológicos (como os "chips" citados no recorte discursivo que trouxemos), há também o aprimoramento de funções, e dentre esses aprimoramentos, comparece a "realidade aumentada", um aprimoramento que vai incidir no campo visual, no olho como órgão.

Se óculos e lentes de contato até então se voltavam a corrigir as falhas da lente do olho humano, se o telescópio e o microscópio se voltavam a superar a visibilidade proporcionada pela retina, como dissera Freud (1930/2010), no século XXI acompanhamos o olho receber lentes de contato e óculos que prometem conexão com a rede eletrônica e a realidade aumentada, esta apontada como a possibilidade de uma "visão sobrehumana" ${ }^{26}$, antes possível apenas na ficção científica. Assim, se antes os objetos tecnológicos, principalmente aqueles destinados a corrigir falhas, como por exemplo dos olhos, se voltavam ao campo da superação de déficits, hoje assistimos esses objetos sendo produzidos supostamente para ampliar a capacidade, no caso, do que se vê. Trata-se de uma capacidade possibilitada com o objeto tecnológico e bem específica: ver tanto a imagem da "realidade" quanto a imagem produzida pela "realidade aumentada" sem necessidade de uma tela materializada, mas sim uma tela virtual que é projetada diretamente na retina. Todavia, apontamos que, da maneira como a realidade aumentada é sustentada discursivamente produz sentidos de que o olho que não possui o objeto tecnológico é um olho não potente, quiçá deficitário, o que favorece mais uma vez o mercado, a busca dos sujeitos pelo objeto. Não deixaremos de apontar aqui que as evoluções tecnológicas têm sua importância e seu campo de aplicação, todavia ela não precisa circular no âmbito do ter ou não ter o objeto (tecnológico), ter ou não ter potência, tudo ver, posto que de fato a realidade aumentada não aumenta em nada a potência natural do olho, apenas

\footnotetext{
${ }^{26}$ Recuperado em 10 de janeiro de 2014, de http://jornalggn.com.br/noticia/lentes-de-contato-inteligentesgarantem-\%E2\%80\% 9 Cvisao-sobre-humana\%E2\%80\%9D
} 
disponibiliza outras imagens, as aumenta, imagens às quais o olho não terá acesso total já que há uma seletividade no campo imagético pelo órgão.

Faremos uma breve apresentação dos objetos, por meio das Figuras 11, 12 e 13, nos quais está sendo desenvolvida a realidade aumentada (Figura 14), ou seja, a projeção de imagens diretamente na retina, que permite a sobreposição de imagens do ambiente natural e do ambiente virtual, e teceremos alguns apontamentos sobre esses objetos sob os quais incidem discursos que convocam a face e o olho a serem interface do objeto, e destituem os dedos e tantas outras partes do corpo, assim como tantos outros periféricos, do ato de conectar-se ao objeto tecnológico e a rede eletrônica.

Se na Figura 11 podemos observar o acoplamento dos óculos que conectam a rede eletrônica na face do usuário, na qual um prisma é alocado na frente do olho para projetar as imagens diretamente na retina, na Figura 12 podemos acompanhar a ilustração do modo de utilização do objeto e sua descrição, que tanto abarca a apresentação do produto quanto o modo de interação entre sujeito e objeto tecnológico, via corpo. Apontamos que para fazer interface com o objeto, a voz, a visão, o toque, são convocados para acionar os óculos. Tal acionamento por parte do sujeito-corpo está sujeito ao que o objeto faz, o que podemos acompanhar observando a enunciação "O que ele (óculos) faz" (Figura 12 - imagens a direita), seguida de ilustrações. Aquilo que o objeto faz está por sua via sujeito aos comandos do sujeito. Nessa relação, tanto a parte do corpo mobilizada para interfacear, quanto o objeto, estão sujeitos ao modo de utilização, que é governado pelos sentidos legitimados de miniaturização e acoplamento ao olho, em um contexto em que a visibilidade se torna produto mercadológico e alvo de discursos de potência.

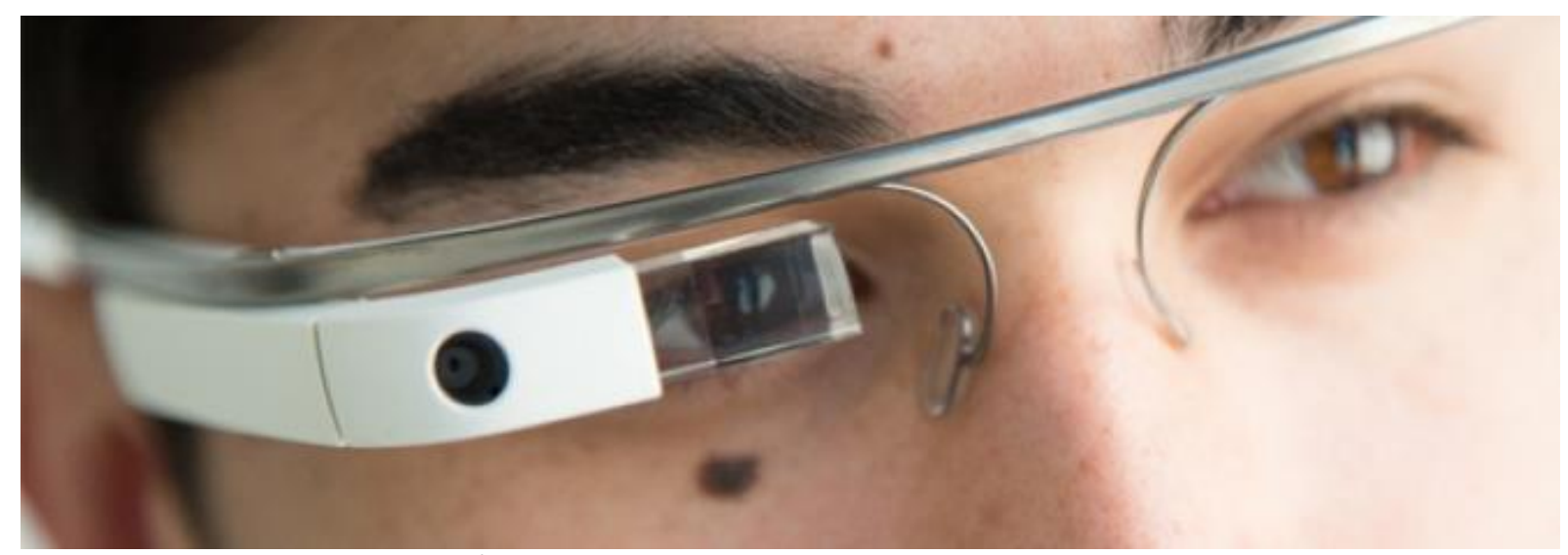

Figura $11^{27}$ - Google Glass - óculos que conecta a rede eletrônica

\footnotetext{
${ }^{27}$ Recuperado em 07 de janeiro de 2014, de http://canaltech.com.br/noticia/google-glass/Google-Glass-devechegar-ao-mercado-em-2014-e-custar-menos-que-o-iPhone/\#ixzz38uOBa7RW>.
} 


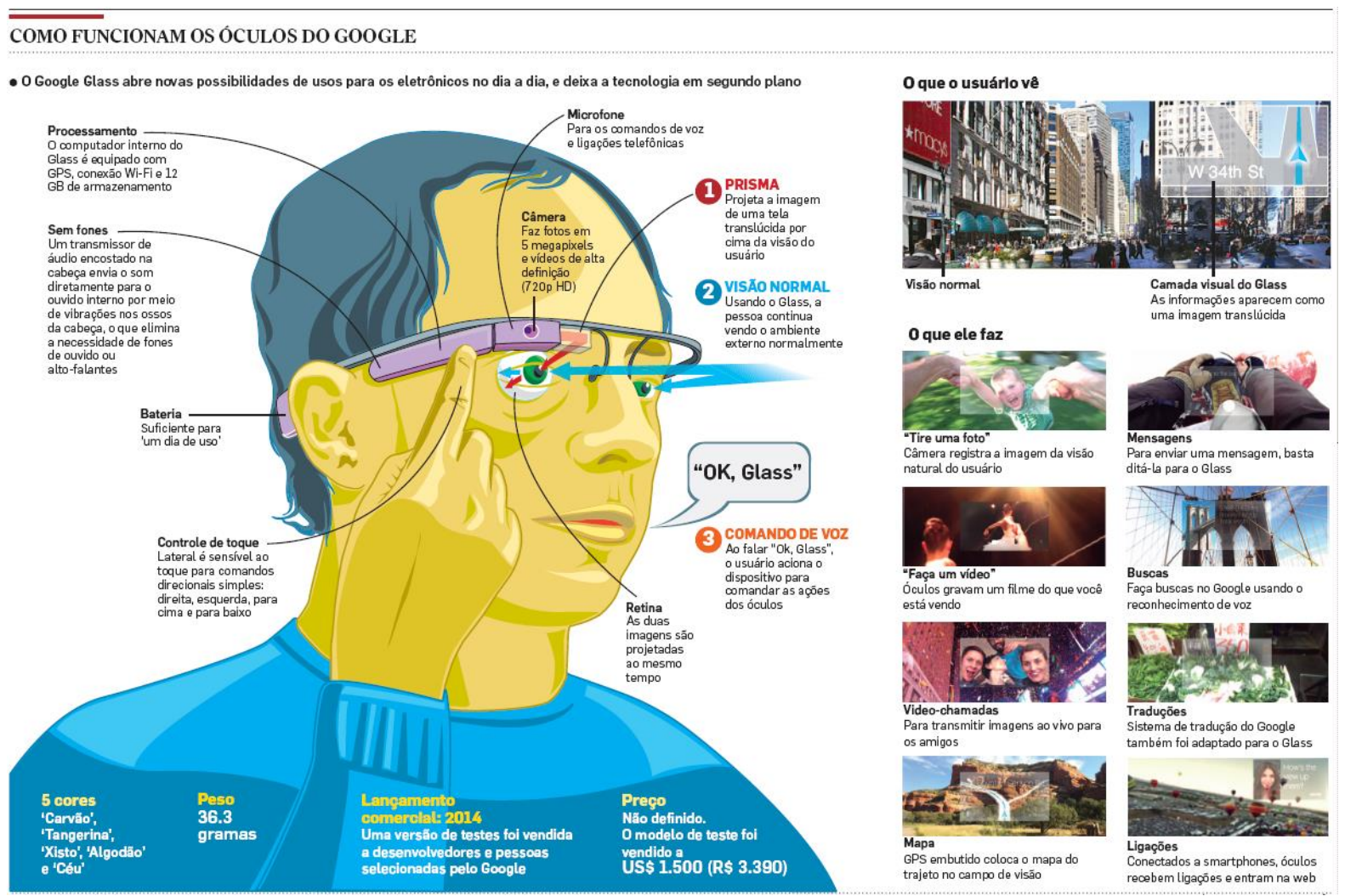

Figura $12^{28}$ - Modo de funcionamento do Google Glass

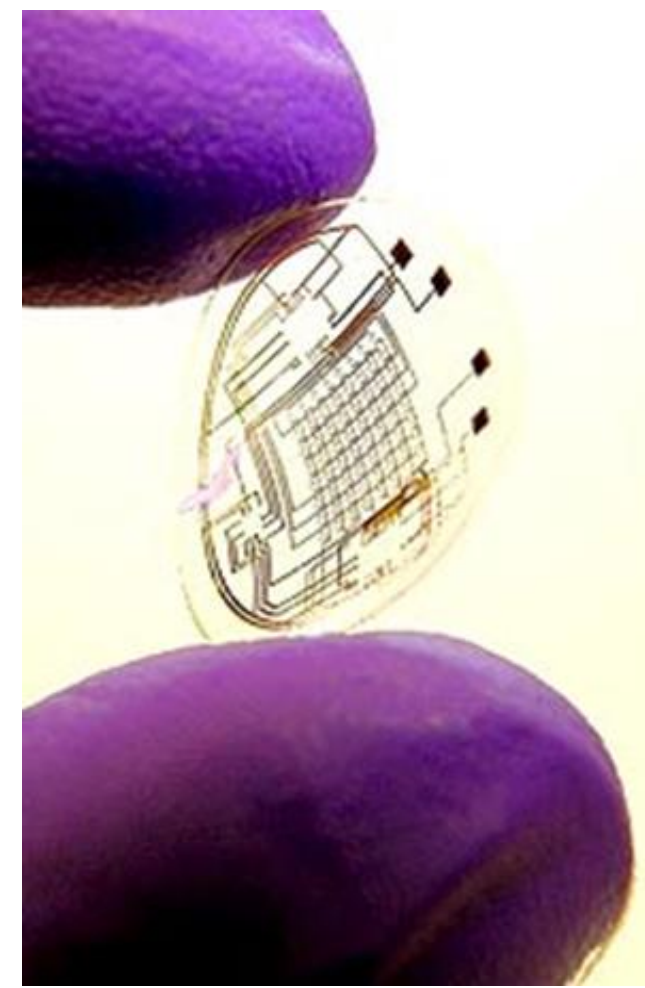

Figura $13^{29}$ - Lente de contato que conecta a rede eletrônica

\footnotetext{
${ }^{28}$ Recuperado em 04 de agosto de 2013, de http://blogs.estadao.com.br/homemobjeto/files/2013/08/googleglass.png>.

${ }^{29}$ Recuperado em 10 de junho de 2013, de http://tecnologia.terra.com.br/noticias/0,,OI2246293-EI12882,00-

Estudo+desenvolve+lente+de+contato+que+acessa+web.html
} 


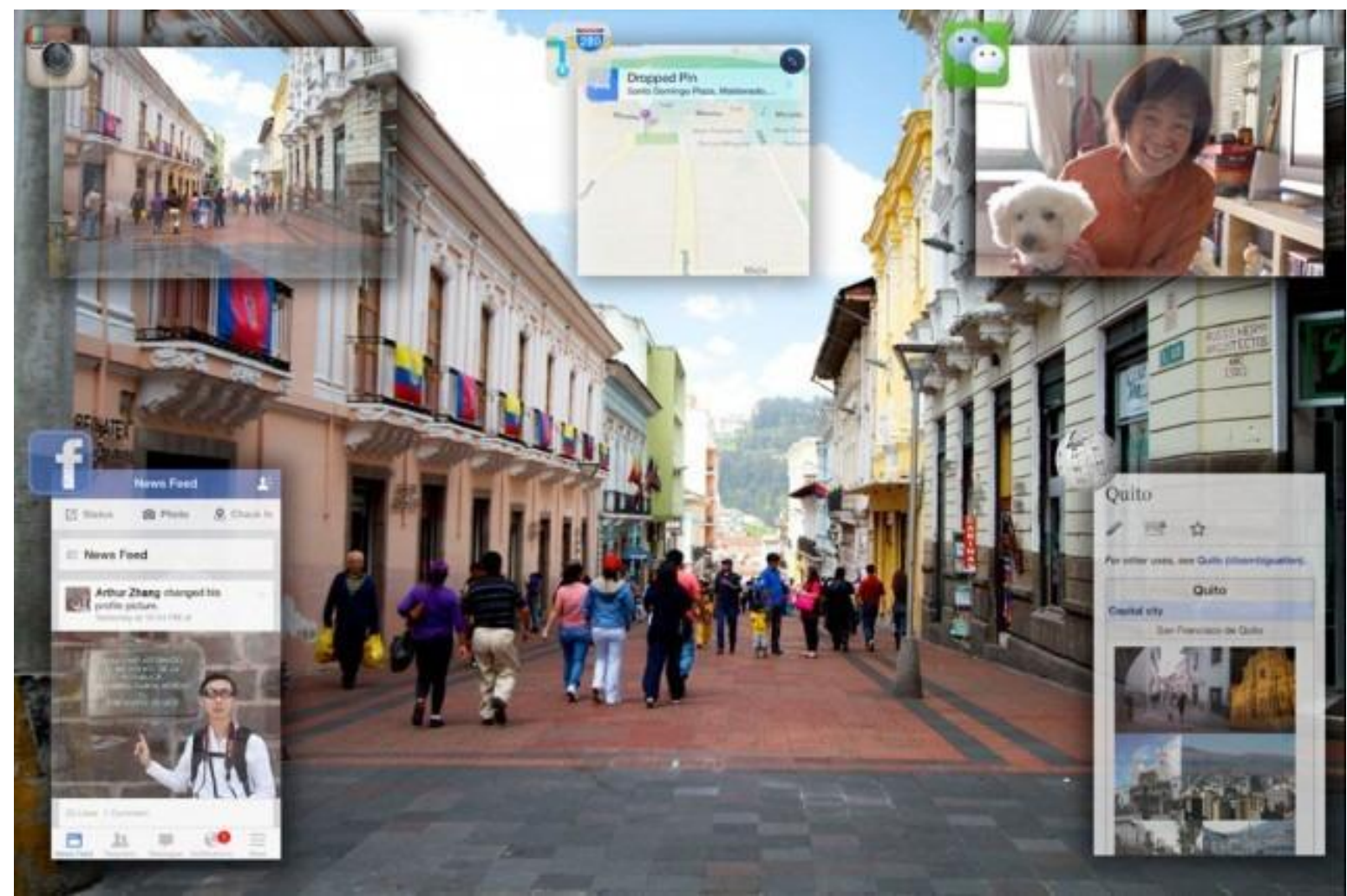

Figura $14^{30}$ - Imagens da realidade aumentada proporcionada pelas lentes de contato (e também pelos óculos) que conectam a rede eletrônica

Na Figura 13 podemos observar a lente que conecta a rede eletrônica com seus eletrodos, o que a diferencia consideravelmente de uma lente de contato voltada para corrigir falhas da visão. Salientamos que essa lente não faz ver melhor a realidade, ela sim oferece uma sobreposição de imagens, dispensando a materialidade de uma tela, e ainda dispensando um objeto que tenha que ser manuseado, carregado. A lente acopla-se ao olho, apresenta-se como objeto que se sobrepõe ao olho, e dele faz interface a partir dos comandos de piscadelas. Dispensa a voz, o toque e qualquer outra parte do corpo na medida em que basta o olho para a interação. A Figura 14 ilustra a realidade aumentada, que ainda contempla a possibilidade do zoom em imagens, tornando-as maiores. Salientamos que todas essas modificações no objeto tecnológico para se acoplar ao olho, são acompanhadas de efeitos de potencialização do olho, sendo suposto ver mais, ver além, seja pela ampliação das imagens, seja pelo vislumbramento de duas realidades, e, por outro lado, silenciam que ainda que todas essas imagens sejam ofertadas, o olho é seletivo, como veremos no próximo capítulo com Lacan (1998d).

Assim, acompanhando o deslizamento de um objeto tecnológico a outro, desde o computador Eniac até as lentes de contato, que estão em fase de pesquisa e teste, pudemos

\footnotetext{
${ }^{30}$ Recuperado em 10 de janeiro de 2014, de http://jornalggn.com.br/noticia/lentes-de-contato-inteligentesgarantem-\%E2\%80\%9Cvisao-sobre-humana\%E2\%80\%9D
} 
apontar a miniaturização, a potência do objeto, o acoplamento ao corpo ou a partes dele que são clamadas a comparecer como interface, e, no capítulo 5 poderemos acompanhar como essas partes do corpo são embebidas em discursos de potência, assim como o corpo é embebido em sentidos de potência no ambiente virtual. Sobre tais objetos, produzidos pela ciência, e alavancados pelo poder do Mercado (Payer, 2005), temos a dizer que na promessa de ofertar um objeto tecnológico que sustente "Das Ding", o discurso do mercado insiste em fazer semblante de causa de desejo, na pulverização das latusas (Lacan, 1992) ou servomecanismos (Braunstein, 2010), que, se têm uma importante função e aplicabilidade na pós-modernidade, por outro lado, são enlaçados a enunciados que sustentam a busca pela completude, ao mesmo tempo em que esvazia a busca do sujeito, e a lança novamente incorporada em outro objeto tecnológico, que, como afirmamos aqui, cada vez mais convocam o corpo ou partes dele na conexão e convocam a sentidos de (im)potência.

No próximo capítulo, nos dedicaremos ao estudo do corpo. E, para tanto, articularemos a historicidade dos sentidos que nele incidem em cada contexto sócio-histórico, e, posteriormente, o abordaremos como conceito na Análise do Discurso e na Psicanálise, para apresentarmos o que denominamos posição-sujeito corpo (inter)face. 


\section{O CORPO NO/DO DISCURSO E O DISCURSO NO/DO CORPO}

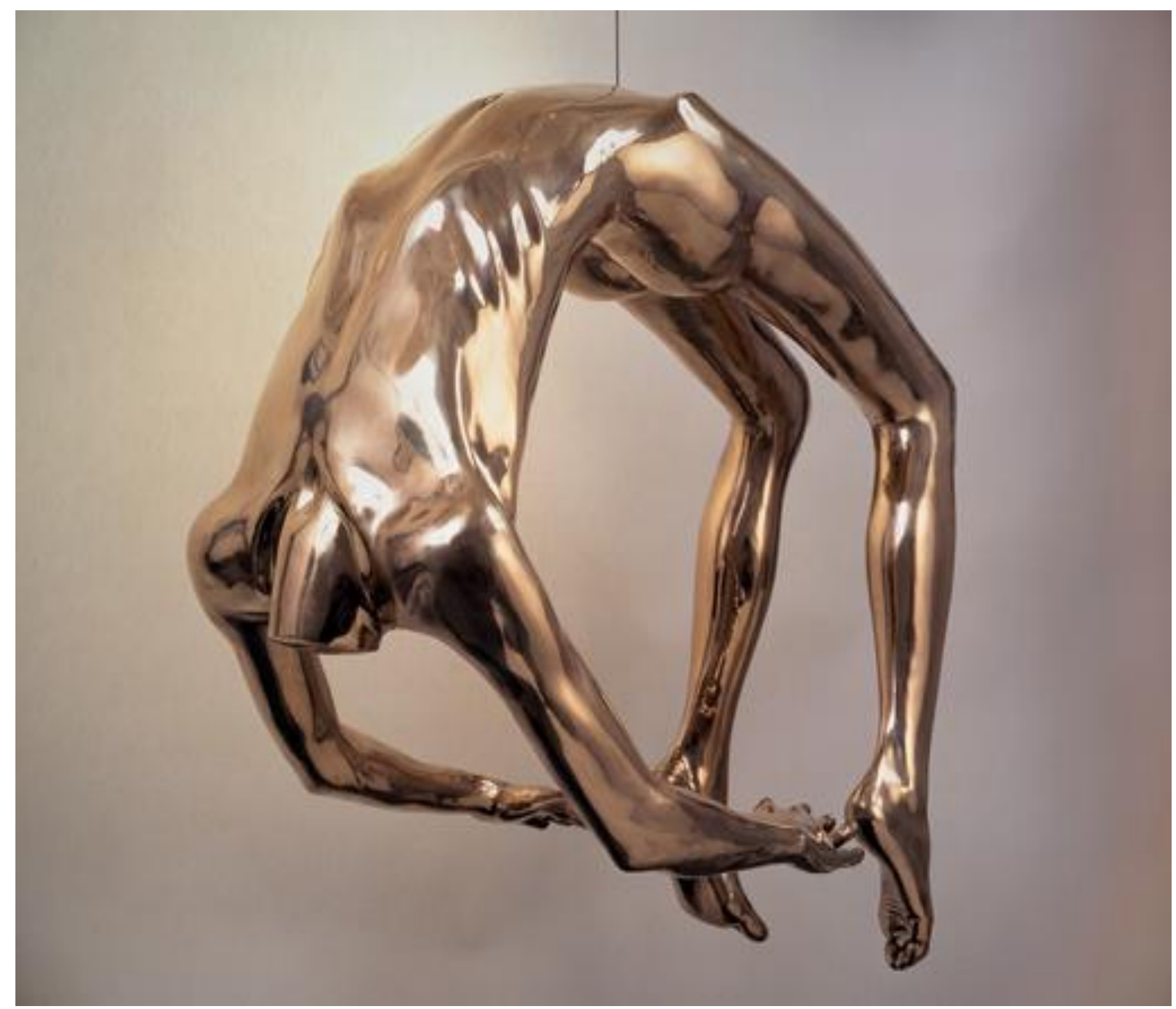

Arch of Hysteria (Louise Bourgeois, 1993)

Vivo, vivíssimo

[...] Trato de habituar-me sem excessivo dramatismo à ideia de que o corpo não é só finível, como de certo modo é já, em cada momento, finito. Que importância tem isso, porém, se cada gesto, cada palavra, cada emoção são capazes de negar, também em cada momento, essa finitude? Em verdade, sinto-me vivo, vivíssimo, quando, por uma razão ou por outra, tenho de falar da morte... 
Como Pêcheux (2009a) aponta, a língua é a base para os processos discursivos, e nesse capítulo, acompanharemos como a língua sustenta modos diversos de discursivização sobre o corpo. Considerando que as questões que norteiam essa pesquisa tomam como mote a discursivização sobre o corpo a partir dos discursos sobre os objetos tecnológicos de conexão à rede eletrônica, e, considerando que em cada contexto sócio-histórico o sujeito é interpelado de um modo para dizer sobre a relação do corpo com os objetos, apresentaremos a historicidade de sentidos sobre o corpo ao longo dos séculos. Apontamos também que não há só um modo de dizer sobre o corpo em cada contexto sócio-histórico, porém, há sentidos legitimados que, portanto, silenciam outros. Particularmente, em nosso contexto sócio-histórico nos interessamos pelos sentidos silenciados, e indicamos que podemos escutá-los a partir do que é legitimado, como delineia Orlandi (2007a).

Abordaremos, então, o conceito de ciborgue como um modo de dizer sobre o corpo na relação com os objetos tecnológicos de conexão à rede eletrônica, que tem sido legitimado neste contexto sócio-histórico. De outro modo, apresentaremos o conceito de corpo para a Psicanálise e para a Análise do Discurso, dois campos que levam em consideração o corpo como efeito de discurso e de sentidos e que nos auxiliam a pontuar os efeitos do discurso no corpo. A partir de todo o campo teórico abordado, apresentaremos a noção de posição-sujeito corpo (inter)face, que, desprendendo-se do sentido único veiculado nos sentidos sobre ciborgue, pretende apontar como que o sujeito se posiciona no discurso, identificado com a formação discursiva do mercado, atravessado por sentidos de um corpo que, na interface com o objeto tecnológico, é considerado potente, e como silencia outros sentidos. Comecemos com um percurso pela historicidade do corpo.

Conforme nos lembra Romão (2007, p. 217), no campo da Análise do Discurso, a compreensão dos processos constitutivos do discurso se dá em função das condições de produção, tendo em vista “[...] que a exterioridade é parte integrante do dizer e não algo que está na borda ou no entorno dele (PÊCHEUX, 1969)", ou seja, a exterioridade não é algo que está fora, na medida em que atravessa discursos, sentidos, sujeitos, corpos e os constitui. Se a historicidade é inerente às condições de produção dos discursos, já que por condições de produção entendemos tanto o contexto sócio-histórico quanto as condições imediatas da produção de um dizer (Orlandi, 2010) a historicidade tem a ver com a exterioridade.

Segundo o Glossário de Termos do Discurso (2001), a história, para a Análise do Discurso, se define por sua relação com a linguagem e se organiza a partir das relações de poder. Ao nosso ver, ela não é encapsulada na cronologia e na concepção de evolução, dado que a Análise do Discurso trabalha com o processo de produção dos sentidos de forma a compreender 
os acontecimentos históricos, e, para isso, toma a ideologia como conceito norteador que indicia que alguns sentidos são legitimados em dado contexto sócio-histórico. Os outros sentidos somente estão "silenciados" (Orlandi, 2007a), ou a se produzir. Assim, a ideia de cronologia e de evolução são entendidas, na Análise do Discurso, apenas como marcos que representam o atravessamento ideológico do que pode e deve ser dito. Trabalhamos com a historicidade, que se constitui como conceito que leva em conta a história enquanto processo de produção de sentidos e não rastreamento de dados históricos.

Dialogando com o que apresentamos sobre o conceito de historicidade, trazemos as contribuições de Corbin, Courtine e Vigarello (2008, p. 7), autores que afirmam que é o mundo imediato que restitui uma história do corpo, “[...] um mundo que varia com as condições materiais, os modos de habitar, os modos de garantir as trocas, de fabricar objetos [...]" e que, ao nosso ver, passa pela incidência ideológica. Apoiados em Mauss (1974), os três autores assinalam como os gestos humanos, aparentemente naturais, na verdade são produzidos, fabricados pelas normas coletivas. Concordando com estes, podemos ler as normas coletivas como formações discursivas e ideológicas que sustentam os discursos e os sentidos em cada contexto sócio-histórico, assim como as posições-sujeito. Conforme os referidos autores e, sobretudo Mauss (1974), o andar, o jogar, o dormir, o comer são oriundos de dinâmicas temporais atravessadas por visões de mundo diferentes e, consequentemente, investimentos diferentes no corpo. Acrescentamos os modos de discursivização do corpo como constituintes dos modos de comparecimento deste objeto simbólico na história. Faremos, portanto, um percurso pela história do corpo e buscaremos trazer aspectos da produção de sentidos em cada contexto sócio-histórico, a historicidade.

De acordo com Leandro-Ferreira (2013), o sentido dominante sobre o corpo na civilização grega centrava-se na busca da beleza associada a perfeição. Sentido que não se findou nesse contexto sócio-histórico, e sim se mantém e se manteve nos outros, sustentado por discursividades outras. E, se na civilização grega havia uma exaltação do corpo com uma exposição da beleza, a partir do Cristianismo, com o corpo de Cristo exposto morto na cruz e os discursos que sustentaram esse momento religioso, o corpo passou a ser tomado como objeto pecaminoso, que devia ser "ocultado", com vestes. De um período histórico a outro, assistimos então à movimentação discursiva sobre o corpo. Se na Grécia Antiga este era cultuado por sua beleza perfeita, após a Antiguidade Clássica os discursos comparecem de modo a controlar o corpo encoberto. Ainda assim, o corpo está em destaque já que encobrir é também referir-se ao mostrar. 
Conforme Leandro-Ferreira (2013), com a força da ascensão do capitalismo, o corpo sacralizado na Idade Média perde espaço para a manipulação. Ele não está mais escondido. Pode ser tocado, examinado, investigado. Os discursos incidem nos detalhes de um corpo desnudo. A autora afirma que no Renascentismo, o ser humano passou a ser considerado parte da natureza e, conhecer a natureza passou a significar conhecer o ser humano. O corpo, então, visto como um instrumento natural, não era somente alma, mas também carne, sentidos. Corbin, Courtine e Vigarello (2008), abordando esse período da Renascença, apontam que, no século $\mathrm{XV}$, o corpo, as doenças, os temperamentos, as concepções sobre o homem foram perpassadas pela crença em influências secretas, como forças cósmicas apoiadas no zodíaco, na localização dos planetas, na crença em alguma potência mágica que poderia invadir o corpo. E, conforme Leandro-Ferreira (2013, p. 101), “[...] A entrada em cena de uma ciência positiva separada de valores religiosos e do espaço da moralidade [...]”, deslocou o corpo do campo das crenças e o centrou como objeto de estudo de algumas ciências, principalmente da medicina, e, os estudos sobre anatomia despertaram o interesse de artistas. O corpo, então, passou a ser alvo de estudos em diversas áreas do conhecimento, "[...] fato que demarca um momento revolucionário no percurso de sua concepção ao longo da história” (p. 102). Fato que não é tomado na Análise do Discurso como um mero dado, mas como indício de como os discursos se apresentam em torno de um objeto simbólico em dado contexto.

No que tange a esse corpo retratado e mapeado em seu funcionamento, podemos fazer outras associações com Dias (2012, p. 27), que aborda sobre o momento das grandes navegações e a movimentação do homem em direção a outras terras, marcando no deslocamento do corpo, no atravessamento de oceanos, uma virtualidade: as coisas "[...] saem do alcance material do olho para alcançar fisicamente os espaços virtuais". A autora afirma que esse movimento propiciou “" [...] uma ruptura com a corporeidade, já que o olho sai do corpo para ver além, para alcançar territorialidades outras, através da utilização de instrumentos e mapas. [...]”. Podemos associar esse momento em que metaforicamente o olho se lança para fora do corpo para avistar outras terras, atravessando oceanos, com a metáfora do "navegador" da internet. Tanto o provedor quanto aquele que navega nas águas cibernéticas para aportar em outros locais por meio dos links. Desse modo, uma memória incide no ato de "navegar" do século XXI que rememora sentidos de outrora, mas com a atualidade de ser um deslocamento do corpo pelas águas cibernéticas, sem sair do lugar e na instantaneidade de um tempo outro. Dias (2012) aponta, assim, que a desterritorialização do olhar começa com a pintura e vai até as ideias de projeção da cartografia de Mercator, e, acrescentamos, chega aos discursos de uma suposta infinitude na rede eletrônica, que fisga os olhos para a contemplação das telas dos objetos 
tecnológicos, mapeadas por links, imagens, (hiper)textos, redes sociais, que guiam os olhos para outros espaços virtuais e outros espaços virtuais.

Após essas associações, retomamos com Vigarello (2008), o fato de que no século XVII, o corpo, concebido enquanto discurso dominante, fora do âmbito da influência dos planetas, das forças ocultas, passa a estar sujeito à Física, à lei de causa-efeito, ciência que se estabelece na Renascença. De acordo com o autor, o funcionamento do corpo é associado ao funcionamento das máquinas, como os relógios, as bombas, os pistons, as engrenagens, as alavancas, e apontamos o quão interessante é essa colocação, já que ela inverte a concepção de que as maquinarias foram espelhadas no funcionamento do corpo humano. Podemos, então, indiciar a relação corpo e objetos tecnológicos entrando já nesse contexto sócio-histórico num campo de con-fusão, no qual o corpo comparece sob a ordem maquínica. No século XX, vemos Le Breton (2003) escrever que “[...] não se compara a máquina ao corpo, compara-se o corpo à máquina [...] Se não é subordinado ou acoplado à máquina, o corpo nada é [...]” (p. 19) e, nesse recorte de sua obra, podemos apontar a memória de outrora já subordinando o corpo à máquina. Retomando Freud (1930/2010), o homem elabora objetos visando a extensão de seu corpo, o controle do espaço e tempo, e, como também já apontamos com Lemos (2010b), o corpo tem sido discursivizado como fusionado aos objetos tecnológicos. Lembremos que os discursos que tomam o corpo como suporte da máquina unindo corpo e máquina é uma das questões dessa pesquisa. Podemos, então, dizer que os sentidos são construídos, têm uma memória que os sustenta via repetição e regularização, e que há polêmica na relação corpo-máquina desde outros tempos.

Ainda sobre a Renascença, Dias (2012) aponta que um dos mais importantes fundadores da visão renascentista, que marcou a passagem da Idade Média para a Idade Moderna, foi René Descartes com a proposição de duas categorias da realidade - a categoria do material representada pelo corpo e a categoria do imaterial representada pela alma. A autora diz que esse dualismo foi se dissolvendo com a crença de que o mundo era infinito e que, portanto, não poderia haver outra realidade que não fosse a da matéria, ou seja, do corpo e dos objetos que compõem o mundo, que passa, como vimos, a ser mapeado, assim como o corpo. De acordo com Vigarello (2008), é na Renascença que o corpo se singulariza. Segundo este autor, "Uma dupla tensão [...] atravessa o investimento no corpo, da Renascença às Luzes, esboçando as primícias das visões de hoje: uma acentuação das imposições coletivas, uma acentuação da libertação individual [...]” (p. 17), sendo que a sujeição é inscrita como libertação. Tal afirmação nos remete ao que Pêcheux (2009a) aponta sobre o assujeitamento com ares de liberdade, sustentado pelo discurso jurídico, sobretudo no século XX e ainda no século XXI. Portanto, nos 
remete ao conceito de sujeito tecido por Pêcheux (2009a). Como vimos, uma noção de sujeito atravessado pela ideologia e pelo inconsciente, que sob o efeito dos esquecimentos $n^{\circ} 1$ e $n^{\circ} 2$, acredita que as palavras nele se originam, apagando a anterioridade destas, e acredita que aquilo que diz só pode ser dito como foi dito, apagando ideologicamente outras formas de significar e dizer. Esse sujeito, atravessado pelas condições de produção, ocupa uma posição (ou mais) no discurso, na história.

Em consonância ao que estudamos, Corbin, Courtine e Vigarello (2008) ao traçarem um levantamento datado sobre o corpo, apontam que, embora em cada momento histórico haja uma predominância de sentidos que circulam sobre o corpo, outros sentidos que já circularam se fazem presentes, o que associamos ao efeito dos já-ditos que circulam no campo da memória, conforme assinala Pêcheux (2009a). Quanto a isso, os três autores apontam que os efeitos de sentido sobre o corpo na Renascença se "libertam" das influências religiosas ou místicas, mas salientam que não se deve ignorar a influência dos referenciais religiosos no que tange as partes nobres e indignas do corpo, nem as crenças, nem as monstruosidades explicando a influência de alguma instância malévola. Apontamos então, que a língua como palco para os processos discursivos é a base (Pêcheux, 2009a) para que ora um processo discursivo entre em cena, ora outro e ora outro, nas diversas composições possíveis para uma peça teatral em dado contexto, sustentados pela memória do dizer, e ainda pelo interdiscurso. Na incidência de um discurso e outro, se dá a heterogeneidade no discurso. Assim, os sentidos e os discursos vão se contrapondo, se recombinando, se deslocando, abrindo espaço para a circulação de outros, sob o efeito da ideologia.

Deslocando-nos, então, para a modernidade, Corbin (2008) e Leandro-Ferreira (2013) sinalizam que no século XIX, o corpo é estudado predominantemente pela medicina anatomoclínica e pela frenologia. Segundo Corbin (2008), a anestesia é criada neste contexto e passa a permitir maiores intervenções na carne. Iniciam-se também estudos sobre a sexologia, sobre o corpo em movimento, ou seja, o estudo sobre os esportes, e também é momento em que novas máquinas são criadas com a Revolução Industrial. Todas essas invenções passam a influenciar o corpo, os modos de se lidar com o corpo, e, acrescentamos, os processos de constituição de discursos sobre o corpo. De acordo com o referido autor, a partir da Idade Moderna o corpo é tomado como objeto que ocupa lugar no espaço e ele mesmo é um espaço com seus desdobramentos, pele, voz, órgãos. Como objeto da ciência, cada vez mais ele é manuseado, dissecado, medido, analisado, transformado. Todavia, conforme aponta Corbin $(2008$, p. 7), “[...] este corpo dos anatomistas ou dos fisiologistas é radicalmente diferente do corpo do prazer ou da dor". Dito de outro modo, ao mesmo tempo em que é medido, calculado, 
mapeado, ele também é corpo sujeito ao inconsciente. Segundo o autor, a partir do século XX, com a psicanálise, a concepção da porosidade das fronteiras entre o dentro e o fora, entre o corpo sujeito e o corpo objeto, tornou-se mais refinada e complexa, como vimos na seção 2.1 nas questões que Freud (1930/2010) aponta sobre as fronteiras entre o eu e o externo, e o corpo passou a ser considerado ficção, imagem inconsciente, conjunto de representações mentais que se elaboram na história do sujeito, mediadas por discursos sociais. Para Courtine (2008, p. 8), o século XX é que inventou o corpo teoricamente enquanto conceito e enfatiza que

Essa invenção surgiu em primeiro lugar da psicanálise, a partir do momento em que Freud, observando a exibição dos corpos que Charcot mostrava na Salpêtrière, decifrou a histeria de conversão e compreendeu o que iria constituir o enunciado essencial de muitas interrogações que viriam depois: $o$ inconsciente fala através do corpo. Este primeiro passo foi decisivo, dado que abriu a questão das somatizações, e fez que se levasse em conta a imagem do corpo na formação do sujeito [...].

Sobre a questão da imagem do corpo, conforme destacam Corbin, Courtine e Vigarello (2008), no contexto sócio-histórico ao qual nos referimos, uma subversão da supremacia da instância da consciência sobre o corpo foi alavancada por Wallon, contemporâneo de Freud, que inverteu essa premissa em seus estudos ao afirmar que é o corpo que conduz à consciência e não o contrário, tal como Freud (1923/1996e) já havia apontado. Na sequência desses pensadores, Lacan (1998d), tece sua teoria do estádio do espelho, na qual afirma que o eu é constituído a partir da imagem do corpo, como veremos mais adiante. Além da psicanálise, Corbin, Courtine e Vigarello (2008) destacam que os estudos de Husserl, que faziam do corpo o berço de toda significação, o qual influenciou da fenomenologia ao existencialismo, e a teoria de Mauss sobre as "técnicas corporais", ou seja, “[...] 'as maneiras como os homens, sociedade por sociedade, de maneira tradicional, sabem servir-se do seu corpo' [...]” (Courtine, 2008, p. 8), também trouxeram importantes pontos para se conceber o corpo como objeto teórico, no campo das ciências humanas. Leandro-Ferreira (2013) enfatiza que na obra de Mauss é possível encontrarmos fundamentos para compreendermos o corpo como lugar de observação do sujeito, pelo fato de apresentar o corpo como o primeiro instrumento do homem, e, acrescentamos, primeiro instrumento que permite sua constituição como eu e como sujeito do inconsciente (Freud, 1923/1996e; Lacan, 1998d).

Prosseguindo com Corbin, Courtine e Vigarello (2008, p. 11), apontamos que a abordagem do corpo mobiliza as ciências de maneira geral, mas conforme os autores, ao longo do tempo, “[...] algumas lógicas podem dominar sobre as outras [...]”, por exemplo, “[...] A 
lógica mecânica no século XVII, a lógica energética no século XIX, a lógica informacional no século XX [...]”. Conforme vimos no capítulo 2, é no século XX que são criados os primeiros computadores e a rede internet, e a partir desse momento, assistimos a consideráveis modificações no modo de se conceber o corpo nos discursos legitimados. Conforme Dias (2012, p. 17), "Se, com o Renascimento, há uma ruptura do homem com Deus, através de uma passagem do divino para a matéria, hoje, a matéria retoma a sua forma virtual [...]”.

Sobre isso, Courtine (2008) assinala que há mutações do olhar para o corpo no século XX. Ao nosso ver, parcela dessas mutações do olhar são perpassadas pela lógica informacional, a partir da produção de novas máquinas, objetos tecnológicos constituídos pela linguagem numérica, apresentados a cada dia com uma potência, na intervenção sobre o corpo, e ainda ofertando-lhe a ilusão de estar em todos os lugares, tudo acessar com a rede eletrônica, tudo ver. Conforme o referido autor, “[...] jamais o organismo foi tão penetrado antes como vai sêlo pelas tecnologias de visualização médica [...]” (p. 10), jamais o corpo íntimo conheceu uma superexposição tão acentuada nas redes, jamais as brutalidades da guerra haviam chegado à cultura visual com tanta velocidade, jamais os espetáculos trouxeram tanto a presença do corpo. Assinala, assim, as multiplicações dos corpos virtuais na rede eletrônica, a comercialização de órgãos e sangue, a reprodução assistida, o apagamento da fronteira do mecânico e do orgânico com os implantes, a clonagem, a produção de transgênicos, as cirurgias plásticas, os chips instalados dentro e na superfície do corpo. Embora o corpo seja convocado a essa relação com os objetos tecnológicos, os sentidos sobre um corpo pulsional são silenciados de maneira que se sobressaem os sentidos sobre fusão com o objeto e sobre os deslimites do gozo com este, um corpo dito cada vez mais ilimitado, como apontamos em nossas questões, ao passo que é cada vez mais invadido.

Dias (2012) traz para discussão que a passagem do século XX para o século XXI tem sido marcada por uma mudança importante na concepção de homem e na concepção de mundo, a partir das redes de comunicação e informação em larga escala, que apresentam uma outra dimensão do espaço-tempo, e de corpo. A autora destaca que o imaginário criado em torno do espaço-tempo tecnológico, coloca o corpo num campo de transcendência da vida, da morte, da dor e aponta que "[...] O grande risco do ciberespaço é uma pretensão à universalidade e ao homem ideal. [...]" (p. 43). Nesse sentido, e pensando nas sociedades disciplinares apontadas por Foucault (1991) - nas quais o poder sobre o corpo se dava pela disciplina, Dias (2012) questiona quais são as formas atuais de poder sobre o corpo no século XXI e abre, ao nosso ver, uma importante questão: “[...] Seria o poder das tecnologias digitais, que produzem no sujeito 
o desejo de um corpo perfeito e imortal, colocando-o na lógica da circulação 'de bens'? [...]" (p. 43).

Apontamos que o desejo de um corpo perfeito e imortal não é exclusivo do presente contexto sócio-histórico. Retomando o que apontamos sobre a antiguidade, lá o corpo já era assim visado e podemos dizer que a perfeição e a imortalidade são questões que atravessam cada contexto sócio-histórico. Para além disso, com Freud (1914/1996i) podemos apontar o narcisismo como um dos aspectos estruturais da constituição do sujeito, que o marcam sobremaneira em torno da perfeição, da busca da (auto) satisfação. Todavia, retomando a questão de Dias (2012), o poder atribuído às tecnologias, acentua/se liga a esse traço, alocando corpo e sujeito na esteira mercadológica? A partir do que temos escutado sobre o processo de produção de sentidos sobre a relação sujeito, corpo e objetos tecnológicos de conexão à rede eletrônica, dizemos que sim. Leandro-Ferreira (2013), amparada em Pêcheux (2008), nos auxilia a trabalhar com os discursos sobre o corpo na pós-modernidade, trazendo a ideologia e o inconsciente na produção dos sentidos, discursos e sujeitos. A autora afirma que o sujeito que se acredita livre para fazer do corpo o que quiser e o que a tecnologia lhe possibilitar, é vítima de uma ilusão, encapsulado como ferramenta de controle em um mundo logicamente estabilizado, sustentado pela necessidade de aparência de um "corpo semanticamente normatizado" (Pêcheux, 2008).

Na próxima seção, apresentaremos discursos sobre a concepção de um corpo ciborgue, que, ao nosso ver, traz vestígios dessa ilusão, vestígios de uma busca por um corpo semanticamente normatizado, um corpo ideal, que fisgado pelo imaginário de um rompimento de barreiras corporais, é ciborgue e não mais corpo. Tais discursos são materializados a partir da década de 60 do século XX, como veremos a seguir.

\subsection{O ciborgue}

Robin (2000) afirma que, com a mundialização, não somente as fronteiras dos países se tornaram ultrapassáveis, mas também as fronteiras do corpo, como sua finitude, a partir da relação do homem com a máquina, com a constituição dos chamados "híbridos", relação que fora antecipada pela literatura de ficção científica. A autora faz referência a David Cronenberg e Philip K. Dick como os primeiros a abordarem as fronteiras do de dentro e do de fora e a transgressão dos limites do corpo, no campo da ficção científica. Por outro lado, Robin (2000) 
aborda o caso verídico de Johnny Ray, que, acometido por uma crise de apoplexia, tornou-se completamente paralítico, e, em um experimento passou a controlar um computador com seu pensamento por intermédio de um aparelho eletrônico implantado em seu cérebro. Nessa movência, na qual a ficção passa a ser uma prática cotidiana, se assim podemos dizê-la, na relação do corpo com a máquina, autores como ela própria, Le Breton (2003), Haraway (2009) e Lemos (2010b), dentre outros, trabalham com discursos que sustentam que todos somos ciborgues.

Segundo Le Breton (2003), o termo ciborgue foi criado nos anos 60, no contexto da conquista espacial, por Clynes e Kline, e se referia à criação de um híbrido de homem e máquina que fosse capaz de sobreviver em outras condições, distante da Terra, e cujas qualidades fisiológicas fossem realçadas por próteses técnicas. Para esses autores, a proposta de conjugar a hipnose com injeções farmacológicas a fim de se prevenir problemas metabólicos, psicóticos ou dor, poderiam manter o corpo no seu melhor nível de eficácia nas referidas condições. Conforme Le Breton (2003, p. 204), “[...] O ciborgue visa, portanto, ser um paliativo das insuficiências do corpo [...]".

Lemos (2010b), por sua via, situa a criação do termo ciborgue na ficção científica "The city and the stars" de Arthur Clark, de 1965, sendo este sequencialmente usado no cinema em diversos filmes, sobretudo nos anos 80, na ficção cyberpunk. De acordo com Le Breton (2003), o termo para o acoplamento corpo-máquina ganhou extensão e até banalidade ao abrager a área médica e a vida comum. Repetindo Hables Gray, o autor afirma que nesse sentido o ciborgue não é apenas o Robocop mas também a nossa avó com um marcapasso, ilustrando assim a difusão do termo e da prática que aproxima corpo e máquina.

Para Le Breton (2003), a onipresença dos ciborgues na literatura, nos filmes de ficção científica, nos quadrinhos, nos videogames, ao que acrescentamos conforme ele mesmo disse, na ciência médica, na astrofísica, converte-o em uma figura emblemática pós-moderna a qual propicia muitas análises como as de Donna Haraway. Para Lemos (2010b), nos estudos da cultura, a questão do ciborgue foi introduzida por essa autora em sua proposição de estudar os ciborgues como uma sexualidade híbrida que poderia nos libertar das hierarquias sociais, do racismo e do sexismo, na medida em que faz um enlace da constituição dos seres híbridos com o feminismo na década de 80. Por outro ângulo, Lemos (2010b) afirma que o ciborgue é fruto de uma sociedade paternalista, tecnocrática e militar, tendo em vista sua criação eminentemente bélica. Assim, podemos dizer que as concepções políticas sobre os efeitos do ciborgue são plurais, no entanto, esses autores, Lemos (2010b) e Haraway (2009), se posicionam em conformidade com uma sociedade em que os homens se constituem como ciborgues. 
Haraway (2009, p. 243) conceitua que "Um cyborg é um organismo cibernético híbrido; é máquina e organismo, uma criatura ligada não só à realidade social como à ficção" já que se presentifica desde as telas e páginas da ficção até o interior do organismo na vida cotidiana. Robin (2000), por sua via, apoiada na referida autora, afirma que o ciborgue tornou-se um termo que designa todas as criaturas que se movem no ciberespaço e chama-o de um "entre dois", que é regulado pelo natural e pelo artificial. Em todas as conceituações podemos escutar o misto de natural e artificial operando na questão do que é um ciborgue e Le Breton (2003, p. 28) inclui ainda a representação do corpo como "[...] um gadget, um lugar ideal de encenação de "efeitos especiais'. [...]", uma máquina, se assim podemos dizer, que suplanta a fronteira entre o natural e o artificial, entre corpo, organismo e máquina. Nesses sentidos é possível acompanhar o processo de produção de discursos sobre o corpo fusionado que o alocam como não corpo, por efeito da conexão com a máquina/objeto tecnológico.

De acordo com Haraway (2009, p. 245), “[...] a relação entre organismo e máquina, tem sido uma guerra de fronteiras. [...]”, assim como Robin (2000) apontou. E problematiza tais fronteiras ao sinalizar algumas das quais, segundo ela, estão sendo apagadas, como: 1) a ruptura entre o humano e o animal, a qual foi ultrapassada com a teoria evolucionista, 2) a ruptura entre o animal humano (organismo) e a máquina, que se desfaz cada vez mais quando "[...] Nossas máquinas são perturbadoramente vivas e nós apavoramente inertes” (p. 247), e por último, 3) a fronteira entre o físico e o não físico, a qual tem se tornado muito imprecisa, com os chips, as miniatuarizações, o campo virtual. Lembremos as fronteiras que Freud (1930/2010) aponta entre o eu e o mundo externo, e sobre a fusão "eu-tu" no enamoramento como parte de um imaginário em que corpo e objeto (amoroso/tecnológico) se entremisturam. Podemos, então, apontar que o psicanalista aponta para questões que estão para além do adentramento físico, questões que podemos dizer que estão no campo do imaginário e se materializam em discursos de fusão, de rompimento de barreiras.

Para a autora, a cultura das tecnologizações suplanta os dualismos “[...] eu/outro, corpo/mente, cultura/natureza, macho/fêmea, civilizado/primitivo, realidade/aparência, todo/parte, agente/recurso, criador/criado, ativo/passivo, certo/errado, verdade/ilusão, total/parcial, Deus/homem" (Haraway, 2009, p. 278). Embora tais rompimentos de dualidade se aproximem do pensamento de Pêcheux (2008), no trabalho com as contradições, a autora enfatiza que esse ponto colabora para que se abram questões sobre "[...] quem faz e quem é feito na relação homem e máquina [...]" (p. 278), fisgada pela formação ideológica que legitima o ciborgue, e não abre para questões que polemizem essa relação ou ainda polemizem os sentidos de fusão. 
Na repetição do sentido trazido pela autora, Lemos (2010b, p. 171), embora aponte que “[...] O cyborg é um mito sobre identidade e fronteiras. [...]”, ressalta que "[...] no tempo de micromáquinas, de redes digitais e da realidade virtual, todos nos transformamos em seres híbridos, cyborgs da civilização do virtual, onde a conexão a todo tipo de artefato torna-se, dia após dia, mais numerosa. [...]”, chegando ao ponto de não se saber diferenciar onde começa o homem e onde termina a máquina. Dúvida já apontada por Haraway (2009) e posta por tantos estudiosos do campo da cibercultura, além da literatura e de filmes de ficção científica que trabalham com o imaginário da fusão corpo-máquina.

Também abordando as fronteiras, Le Breton (2003) cita que, para Mazlich (1993), uma quarta ferida narcísica deve ser incluída dentre as levantadas por Freud. Além da revolução de Copérnico que retira a Terra do centro do mundo, da teoria da evolução que inscreve o homem na continuidade do animal e a teoria freudiana que apresenta o inconsciente, acrescenta que a indistinção entre o homem e a máquina se justifica cada vez menos na medida em que não se pode mais conceber o homem sem referência à máquina. Sobre isso, Haraway (2009, p. 282) aponta que “[...] a máquina somos nós, nossos processos, um aspecto de nossa corporificação. Podemos ser responsáveis pelas máquinas: 'elas' não nos dominam ou amedrontam. Somos responsáveis pelas fronteiras; somos estas mesmas fronteiras [...]”. Tal afirmação da autora nos faz pensar nos esquecimentos $n^{\circ} 1$ e $n^{\circ} 2$ que criam a ilusão de que o sujeito é autônomo, de que se acredita na modalidade "Eu sou", apontada por Pêcheux (2009a), atravessado pelas ilusões constituivas de controle.

Por sua via, sobre a questão fronteiriça, Robin (2000, p. 188, tradução nossa) se posiciona e aponta que “[...] o real é tratado como se nós fizéssemos pouco de sua dimensão de impossível" "31, citação à qual nos filiamos ao pensar na questão das fronteiras posto que ao nosso ver estas são imaginárias, ao passo que o real do corpo anuncia o impossível ao corpo e o impossível do ciborgue, o impossível estar em todos os lugares tudo ver, tudo acessar. Como aponta Braunstein (2010), um tudo saber que não é saber de tudo. Le Breton (2003, p. 143), também se posiciona afirmando que:

[...] o virtual apresenta outros usos para o corpo pela simulação de situações por intermédio de uma aparelhagem específica [...] Dissociando corpo e experiência, fazendo a relação com o mundo perder o caráter real e transformando-a em relação com dados, o virtual legitima a oposição radical entre espírito e corpo, chegando à fantasia de uma onipotência do espírito. A realidade virtual está aquém e além do corpo - este é passivo, mesmo que ressoe com os inúmeros efeitos de sensações e de emoções provocadas pela

\footnotetext{
31 “[...] le réel est traité comme si l’on faisait fi de sa dimension d'impossible."
} 
imagem. 'O discurso visionário dos que conceberam o espaço cibernético é cheio de imagens de corpos imaginários libertados das coerções que a carne impõe. Eles prevêem uma época em que poderão esquecer seu corpo' (Stone 1991, p. 113). O espaço cibernético é 'um suplemento de espacialidade (Jameson), livre de qualquer coerção física e de qualquer submissão à espera. Representa um mundo em que o tempo, liberado da duração, converte-se em espaço de puras informações que não requerem mais a corporeidade humana. [...] Diante da tela, está como o astronauta em sua cápsula; seu corpo é uma densidade estorvante que o impede de conhecer a perfeição da rede, tornandose ele próprio informação pura se insinuando entre os interstícios de mundos sem viver mais limites [...].

Desse modo, como apontou o autor, a fantasia de onipotência cria a ilusão de que o corpo é um impedimento, enquanto é o corpo que possibilita a relação com a máquina, que, sendo "relação" que segue a esteira da relação de objeto, é sempre atravessada pelo real, pelo impossível fazer "Um", o impossível da unificação (Lacan, 2003e). Na contramão disso, seguem os discursos sobre o ciborgue, nos quais o corpo comparece como interface. Lemos (2010b), se lançando a algumas reflexões sobre a questão do ciborgue, assinala uma tendência a se antropomorfizar os computadores. Apoiado em Castells, afirma que a cibercultura revela o desejo de juntar o corpo biológico com as tecnologias digitais, e que esse desejo é o cerne da sociedade informacional, ao que acrescentamos, que tal tendência revela o gozo da fusão ao objeto. O autor marca a colonização do corpo pelas tecnologias, as quais cada vez mais se fazem onipresentes, e, ao nosso ver, marcam o processo de constituição de sentidos sobre o ciborgue como uma suposta possibilidade de onipresença, via discurso.

Abordando o desejo de junção entre corpo-máquina, Lemos (2010b, p. 163) diz que "O corpo se funde gradualmente com as novas tecnologias [...]” e assinala que a questão da artificialidade presentificada nos discursos sobre fusão não é algo da atualidade, mas sim está presente desde as primeiras sociedades. Conta que Moscovici, analisando trabalhos antropológicos e paleontológicos, mostra que o homem, em nenhum dos períodos históricos dependeu apenas do orgânico ou do instintivo, que a sociedade se constitui na afirmação de sua não dependência da natureza, sendo nesse sentido, uma contra natureza, e conclui que " [...] A questão do artificial se descola, assim, de uma possível dicotomia com o natural, pois a sociedade e o homem se formam no processo de artificialização do mundo [...]” (Lemos, 2010b, p. 165). Por "artificial", o autor nomeia “[...] tudo aquilo produzido pelo homem e que não tem por si mesmo a possibilidade de se autorreproduzir (autopoiético) ou de criar um gênero [...]" (p. 165).

Para esse autor, como o artificial é profundamente humano, “[...] a questão do cyborg pode ser colocada como estrutural da própria humanidade e como característica inegável da 
cibercultura [...]" (p. 165), e afirma que o primeiro homem que fez de uma pedra uma arma como seu instrumento é o primeiro ancestral dos ciborgues. Lemos (2010b) diz que o imaginário humano é repleto de seres artificiais como Galeteia, as estátuas vivas de Dédalo, o Golem, os homúnculos do Parecelso, os autômatos da Idade Média, os robôs, e, os atuais ciborgues. Assinala que os primeiros seres artificiais vieram ao mundo pelo sopro divino, o sopro que anima o barro. Diz que, assim, o divino anima a obra dos homens ao animar os autômatos pela força da mecânica, são “[...] o gozo da imitação da vida [...]” (p. 168), embora os autômatos e os robôs sejam presos às suas engrenagens.

De acordo com Lemos (2010b), o corpo na relação com o artificial torna-se espaço de experiência: é escaneado, interpretado por processamento de informação, sendo ao mesmo tempo carne e informação. Tanto no campo biológico quanto social, segundo o autor, há um desaparecimento do corpo natural, num processo de interiorização e exteriorização marcados pelos implantes, pelas lentes de contato, pelas nanotecnologias, pelos marcapassos e aponta inclusive a construção de subjetividades pelos media, as quais subdivide em dois tipos de ciborgues, o interpretativo e o protético.

O ciborgue protético, para o autor, representa a simbiose entre o orgânico e o inorgânico, por exemplo, uma pessoa cujo funcionamento fisiológico é auxiliado por aparelhos eletrônicos/mecânicos, como no caso citado por Robin (2000). Já no ciborgue interpretativo não está posta a fusão máquina-carne, mas sim a influência dos mass media. Desse modo, o autor nos nomeia como ciborgues interpretativos, pois na pós-modernidade as pessoas de alguma forma são afetadas pelas mídias. $\mathrm{O}$ autor aborda também sobre o corpo-rede, o qual define como: "[...] o corpo desaparece dando lugar a espectros (Guillaume) que circulam como informações [...]” (p. 173). Apoiado em Rosanay, Lemos (2010b) explana sobre o cibionte, um organismo emergente da simbiose entre o biológico e o cibernético, constituído de um corporede, um cérebro formado pelo cérebro humano, por computador e por redes.

O homem simbiótico, ou o netcyborg, seria aquele 'conectado biologicamente ao cérebro planetário do cybionte...'. O ciberespaço é um imenso corpo sem órgãos, um corpo-rede. Este corpo-rede Cybiôntico, de maneira diferente da atuação da grande rede que conhecemos da televisão, é plural, rizomático, aberto e não centralizado. Ele forma hoje o que poderíamos denominar de Worl Wide Webbed Body (Kroker e Weinstein). Assim, o corpo hipertexto do cyborg da rede nos faz cyborgs interpretativos. Este corpo hipertexto está presente na interface do WWW, nas multipersonalidades dos MUDs e IRCs, na efervescência e agregação das comunidades virtuais [...] (p. 174). 
Articulando sentidos e discursos sobre o ciborgue delineados pelos autores com quem trabalhamos nessa seção, traçaremos uma análise do enunciado "A internet é o sistema nervoso central da sociedade", materializado na Figura 15, buscando trabalhar trajetos de um possível processo de produção dos sentidos que no enunciado reverberam, expondo-o à opacidade.

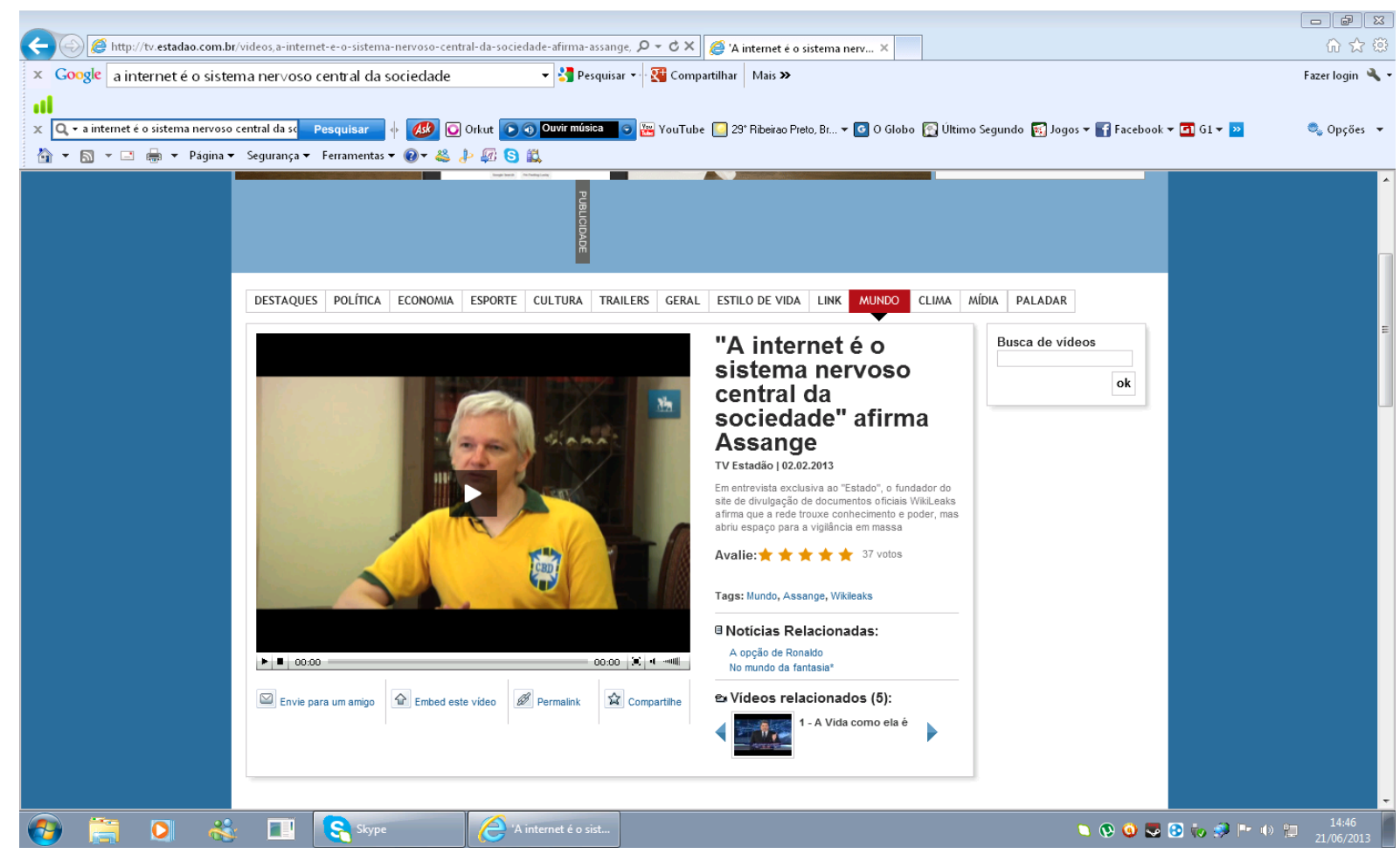

Figura $15^{32}$

Apontamos de início que a enunciação remete a um conceito legitimado na área biológica, qual seja, o "sistema nervoso central". De maneira resumida, segundo Guyton (1988), o sistema nervoso central é formado pelo encéfalo e pela medula espinhal e é o sistema que sente, pensa e controla o organismo. A partir disso, podemos, então, dizer que a enunciação traz a memória de um sistema importante, vital, potente, memória vinculada a uma formação discursiva da área médica, que legitima esse sistema (nervoso), e que é, de certo modo, deslocada dessa formação discursiva para migrar para outra formação discursiva sustentada por uma formação ideológica que legitima um outro sistema, a internet. Assim, o enunciado com o qual estamos trabalhando é atravessado por sentidos que se sustentam em uma formação discursiva orgânica/corpórea que, por sua via, vai dar sustentação a uma formação discursiva

32 Recuperado em 21 de junho de 2013, de http://tv.estadao.com.br/videos,A-INTERNET-E-O-SISTEMANERVOSO-CENTRAL-DA-SOCIEDADE-AFIRMA-ASSANGE, 193887,0,0.htm?pagina=46 
tecnológica, legitimadora da internet, alocando-a na qualidade de sistema (nervoso) central, na qual opera a formação ideológica que legitima que a internet controla a sociedade, fazendo uma associação com o uso do termo "controle" para nomear uma das funções do sistema nervoso central.

Desse modo, tal qual o "sistema nervoso central" está para o controle do organismo/corpo, a "internet" está para o controle da "sociedade", se assim podemos dizer, para o controle do corpo social. O organismo/corpo embora dê sustentação para a função da internet, comparece pela via do sistema, um sistema que não é qualquer, dentre todos os sistemas orgânicos. Se na migração de uma formação discursiva para outra, podemos apontar que há também sentidos que reverberam trazendo as enunciações/questões "O homem controla a máquina? A máquina controla o homem?”, também podemos apontar que, por traz dessas questões, que não cessam de inquietar os autores com os quais trabalhamos nessa seção, está a formação ideológica que comporta o poder do Mercado (Payer, 2005), fazendo operar sentidos de que a máquina, a rede, a internet é vital para a sociedade e cada organismo/corpo.

Dizemos ademais que, na enunciação que analisamos na Figura 15, no deslizamento de uma formação discursiva (orgânica) a outra (tecnológica), ressoa um deslizamento do termo "sistema nervoso central" para um outro sistema, aquele regido pelo código binário, sistema de 0 e 1, sistema que rege a memória metálica (Orlandi, 2012), um sistema que não pára, que pode ficar online (se houver energia, se funcionar), um sistema que se assemelha às especificadades do sistema nervoso central, este também operante no organismo do sujeito sem que ele se dê conta e sem que ele possa controlar, havendo por parte dos sujeitos só um semblante de controle tanto do sistema binário quanto do sistema nervoso.

Dizemos também que, da mesma forma com que as questões comparecem sobre a dominância da máquina ou do corpo, do controle de um sobre o outro, estão as conceituações sobre os ciborgues interpretativo, protético ou ainda do cibionte, que podemos bem encontrar na enunciação. A “internet” sendo classificada como "o sistema nervoso central da sociedade", faz reverberar os sentidos de que somos ciborgues interpretativos, haja vista que estamos expostos às mídias. Metaforicamente, sendo a internet o sistema nervoso central do corpo social, podemos também inferir sobre o ciborgue protético e o cibionte, nos quais a internet compareceria como fusionada ao encéfalo e a medula espinhal do corpo social, concebendo um ser que é misto de corpo social, encéfalo e medula e sistema de informação, resultando daí sentidos de um controle, também ilusório.

Tais nomeações (ciborgues de diversos tipos) silenciam o que intencionamos apontar nos discursos sobre a relação sujeito, corpo e objetos tecnológicos de conexão à rede eletrônica, 
que é o que Pêcheux (2008) não deixou de apontar sobre o real, como aquilo que é impossível ao corpo, ao sujeito, e inclusive aos objetos criados para demandar e suplantar a falta, no jogo do mercado e do consumo. Passaremos a tecer algumas nuances do corpo para a psicanálise.

\subsection{O corpo, segundo a psicanálise delineada por Freud e Lacan}

De acordo com Leandro-Ferreira (2013, p. 103), “O corpo, para a psicanálise, aparece no momento em que Freud se depara com o inconsciente [...]”. O corpo afetado pela linguagem, movido pelas pulsões, constituído na e pela alteridade, como lugar de inscrição do psíquico e do somático, não sendo apenas movido pelo biológico. A partir dessa citação da autora da Análise do Discurso, percorreremos a noção de corpo para a Psicanálise, que, conforme exposto, é corpo pulsional, contornado por linguagem. Ou seja, trata-se de uma noção que não concebe o corpo como um mero organismo, posto que de pronto ele é nomeado, é lhe ofertado um lugar, não passando ileso aos sentidos, aos discursos. Desse modo, faz laço com a noção de corpo da Análise do Discurso, conforme veremos.

Segundo Soler (2001), embora o nome "psicanálise” se refira à análise da psiché, ela é uma prática que tem como ponto central a questão do corpo, especialmente marcado pelo sintoma assim como pelo traumatismo sexual. Para a autora, é a partir daí que Freud estabelece a psicanálise e é esse ponto que também toca Lacan em todo seu percurso, principalmente quando insiste que o sintoma é um acontecimento de corpo. A partir das colocações de Soler (2001), apontamos também que esse conceito se elaborou progressivamente na psicanálise, de maneira pulverizada nos trabalhos de Freud e Lacan, entremeando os demais conceitos. De maneira mais explícita comparece em “O eu e o id”, de Freud (1923/1996e) e n' “O seminário, livro 20, Mais, ainda”, de Lacan (1985).

Em "O ego e o id", Freud (1923/1996e) apresenta uma noção de corpo vinculada ao estudo dos sistemas pré-consciente, consciente e inconsciente, na qual aponta que o corpo tem efeito na constituição do eu e em sua diferenciação do id. Segundo o psicanalista, o corpo é superfície do qual partem percepções internas e externas, e pode ser percebido como um outro objeto; porém, ao ser tocado, as sensações produzidas, inclusive a dor e o adoecimento podem auxiliar na concepção da ideia do corpo, ao compor um contorno ao emaranhado de órgãos. $\mathrm{O}$ próprio percurso do alimento que adentra o organismo e dele evacua, já favorece a percepção de que ali há um corpo. Assim, se é percebido inicialmente como um objeto outro, uma 
dispersão de órgãos, as percepções dão indícios para a constituição do eu e do corpo. No âmbito das percepções, já podemos anunciar que o olhar e a voz, conforme Lacan (2005), trabalham na constituição de um eu corporal, o que aponta para a relação com o Outro. De acordo com Freud (1923/1996e), “O Eu é sobretudo corporal [...]” (p. 24).

Relembremos que Pêcheux (2009a) trabalha com a questão do ego (eu) como o imaginário do sujeito, o qual não consegue reconhecer o seu assujeitamento ao Outro ou ao Sujeito universal, pela ilusão de autonomia, constituindo-se como "Eu sou", e que em "Discurso: estrutura ou acontecimento", vai abordar que esse sujeito que se acredita autônomo sob a forma do eu, constitui essa relação a partir do seu corpo e de seus arredores imediatos, com a distribuição dos objetos, da disjunção alimento e excremento (Pêcheux, 2008). Também na obra pecheuxteana, o corpo não comparece de forma direta, mas a permeia, e é contornado pelos efeitos da psicanálise, e, desse modo, podemos dizer que ambas teorias conversam, ao mesmo tempo que preservam suas especificidades.

Prosseguindo na teoria freudiana, segundo Soler (2001), a partir do estudo sobre o narcisismo e sobre as pulsões, o corpo comparece como pulsional, desnaturado do mundo animal posto que é atravessado pela cultura. Saber, então, como se articulam os mecanismos do inconsciente e as pulsões, os quais se manifestam no corpo, é uma questão importante para a psicanálise desde Freud, que Lacan retoma articulando em termos de mecanismos de linguagem (o corpo é efeito de discurso), pautando-se na linguística, e em termos topológicos, sobretudo com o nó borromeu, no qual articula os registros do real, simbólico e imaginário. Conforme Quinet (2009, p. 69), o corpo estudado por Freud e por Lacan, pode ser assim definido:

O corpo é o eu, feito de imaginário, ou seja, constituído pela imagem especular do eu-ideal composta através do espelho do ideal do eu, que é o ideal do Outro. O corpo é tecido de linguagem, pois ele se incorpora ao grande Outro que é o primeiro corpo, prévio, o corpo simbólico, lugar da linguagem que não se distingue do lugar do Inconsciente. $\mathrm{O}$ corpo tem nome, assim como suas partes, como o demonstra a anatomia. $O$ corpo humano é o único que traz uma marca própria que lhe permite colocar-se numa cadeia significante.

O corpo imaginário não é apanágio do corpo humano, pois como res extensa ele pode ser medido e pesado como qualquer objeto do mundo fenomênico: corpo, cadeira, mesa, lápis. Assim como se pode descrever suas características e atributos como de qualquer objeto. O corpo humano é mais um objeto do mundo fenomênico. O corpo simbólico não é tampouco necessariamente o corpo vivo, pois o cadáver também tem essas características. Ele está preso na cadeia de linguagem e é mortificado pelo significante ao ser tomado no registro simbólico. O significante mapeia o corpo e nele escreve a história e a anatomia histérica próprias a cada um. O corpo é um corpo histoérico. Mas este corpo pode estar morto ou vivo, estar calado no silêncio da pulsão de 
morte ou vibrar com Eros. Para estar vivo este corpo precisa ser também um corpo que goza. Deste modo o corpo está nos três registros: no imaginário do espaço, no simbólico da linguagem e goza como corpo real.

Torna-se importante destacar que o autor toma o corpo como histoérico, uma junção de histeria com história, corpo que, conforme tecemos anteriormente, é afetado pela historicidade, pelos discursos que nele incidem. Pois, se estruturalmente ele é enlaçado aos registros citados, é também afetado pelos fenômenos de cada contexto sócio-histórico. Detalharemos um pouco os registros. Segundo Sternick (2010, p. 31), o Real é o impossível, aquilo que não comporta simbolização, e, por isso, tende a insistência, a não cessar de não se inscrever. Conforme a autora, "[...] dar sentido ao real é a função do simbólico, mas também se sabe que, em contrapartida, o sentido é sempre imaginário [...]”. Assim, é impossível falar de um registro sem se referir ao outro e é por isso que Lacan os articula no nó borromeu n' "O seminário, livro 22, RSI" (ainda não publicado em português), nó no qual se um dos elos é cortado, os demais se desenlaçam. O simbólico é o registro que ordena, que organiza, e é a partir dele que se ordenam o Imaginário e o Real. O Imaginário é o registro que regula a relação dual que um sujeito estabelece com sua imagem e o eu. Teceremos algumas considerações sobre o real, o simbólico e o imaginário no campo do corpo.

Conforme Sternick (2010), para Lacan, o sintoma leva gozo ao corpo e para gozar é preciso ter um corpo, mostrando uma relação intrínseca entre corpo, sintoma e gozo. Por outro lado, segundo a autora, Lacan (2003a) assinala que o corpo pode ser um deserto de gozo, ao que a autora cita um deserto de gozo ao ser tomado como máquina, sendo desvitalizado ao ser comandado de maneira mecânica, por exemplo por órgãos artificiais. O psicanalista francês alerta, assim, para um corpo dessubjetivado, um corpo "vazio de gozo" (Lacan, 2003a). Tal afirmação é intrigante pois vai na contramão do que é legitimado sobre o avivamento/potência do corpo com as máquinas, com os objetos tecnológicos, sobretudo no campo cibernético, e até no campo médico. O psicanalista aponta, assim, que um corpo, não é um mero órgão, ou um emaranhado de órgãos naturais ou não, um corpo deve ser subjetivado. Para Sternick (2010), quando Lacan assinala a incorporação do significante no corpo, ele também aponta que a linguagem subtrai algo do gozo, e, a autora afirma que o gozo em um corpo deserto se fixa nos furos do corpo, nas zonas erógenas, nos objetos pulsionais freudiano, nos objetos parciais segundo Lacan. Portanto, há um efeito do significante sobre o organismo, sob as insígnias da pulsão, passando a ser corpsificado, expressão que equivale a dizer que quem tem um corpo goza dele, contudo, para isso, é preciso apropriar-se desse corpo via linguagem. 
Fazemos um apontamento sobre a fixação nos furos do corpo quando um corpo é um deserto de gozo, pois isso associamos ao gozo na relação com os objetos tecnológicos que cada vez mais se dirigem a um furo, a uma cavidade, no caso de nosso estudo, principalmente ao olho. O gozo que seria com o corpo, gozar de um corpo, corpsificado, desloca-se para um gozo por meio do objeto tecnológico, e sabemos que os discursos sobre os objetos tecnológicos têm elegido partes do corpo para a conexão, como temos dito. Partes que permitem que o corpo fique imóvel enquanto num piscar de olhos, supostamente torna-se movente no plano virtual/da rede, podendo tudo acessar, tudo ver.

Não deixemos de lembrar que Freud associa o corpo ao inconsciente, pela via do sintoma, e em “Televisão", Lacan (2003c, p. 535), discutindo a questão da alma e do pensamento em Aristóteles, e dele discordando, aponta que o sujeito do inconsciente toca na alma por meio do corpo, por nele introduzir o pensamento. Assim, o psicanalista francês afirma que o homem pensa porque a estrutura de linguagem recorta seu corpo, o que nada tem a ver com a anatomia. Nessa discussão, afirma que o corpo é afetado pela estrutura, de linguagem: "Quanto ao sujeito do inconsciente, ele engrena sobre o corpo. Será preciso repisar que ele só se situa verdadeiramente a partir de um discurso, ou seja, daquilo cujo artifício cria o concreto, e como!". Tal afirmação nos lembra a afirmação: “É o mundo das palavras que cria o mundo das coisas [...]" (Lacan, 1998c, p. 277). Por esse percurso pelo pensamento de Lacan, podemos enfatizar que o corpo é contorno de linguagem, é efeito de discurso, e por essa via goza, e deseja.

Em Radiofonia, Lacan (2003b) aponta que o corpo simbólico faz o corpo, por nele se incorporar, e só ser corpo de fato por ser dito em algum lugar, reafirmando assim o atravessamento do corpo por discurso. Segundo o psicanalista francês, é secundário se esse corpo esteja vivo ou morto, posto que antes de nascer o corpo já é contornado por dizer e após morrer também, haja vista as lápides e as memórias daqueles que permanecem. Para Lacan (2003b), a sepultura é o ponto crítico que data o ser falante; lá estão alguns dizeres: nome, nascimento, morte, homenagens. Afirma: “O corpo, a levá-lo a sério, é, para começar, aquilo que pode portar a marca adequada para situá-lo numa sequência de significantes. A partir dessa marca, ele é suporte da relação, não eventual, mas necessária, pois subtrair-se dela continua a ser sustentá-la” (p. 407). O discurso sustenta um lugar para o corpo, um lugar de significante se assim podemos dizer. Vivo ou morto, o corpo é contornado por discurso e, por isso, o corpo goza. 
Apontamos alguns efeitos do corpo real e do corpo simbólico e passaremos a tecer considerações sobre o corpo imaginário, lembrando que, na categoria do nó borromeano ${ }^{33}$, os resgistros são enlaçados, atravessam o corpo concomitantemente, e, se aqui fazemos uma separação é para realçar suas nuances, seu modo de constituição, que, no movimento desejante, algumas das circunferências do nó ganham destaque, como se a cada passo, imaginário, simbólico e real se sobressaíssem, cada um a sua vez, mas na velocidade do giro se entremisturassem ao mesmo tempo, também, preservando suas áreas delimitadas. Salientamos que foi possível a Lacan a formalização do corpo nessa figura topológica, após percorrer cada registro, e no a posteriori reuní-los como um efeito de seu percurso.

Segundo Cukiert e Priszkulnik (2002), a partir da filosofia de Hegel e dos estudos freudianos, Lacan começa a se interrogar sobre a origem do eu, e, pautado na concepção de que o eu se constitui a partir do outro ${ }^{34}$, a partir da imagem que o semelhante lhe devolve, sinaliza o desconhecimento e a alienação como constitutivos do eu. Ponto que podemos associar com o processo de subordinação/assujeitamento delineado por Pêcheux (2009a). Fazendo avançar a teoria de Henri Wallon sobre a importância do espelho para a noção do corpo “próprio”, Lacan assinala o espelho como o semelhante, no qual a criança se espelha para reconhecer o corpo. A alteridade está posta na constituição do eu, e Lacan trabalha com o outro, o semelhante, e, posteriormente com o Outro, como o inconsciente.

Segundo Lacan (1998d), a concepção do estádio do espelho nos fornece esclarecimentos sobre a função do eu, partindo do fato de que o bebê humano, ao passo que é superado em inteligência instrumental pelo chimpanzé, reconhece, todavia, a sua imagem no espelho. Sternick (2010, p. 33) aborda os três tempos lógicos que compõem o estádio do espelho. “[...] No primeiro tempo, a criança vê apenas um outro no espelho; no segundo, ela compreende que

\footnotetext{
${ }^{33}$ Nó borromeano é um figura topológica utilizada pelo psicanalista Jacques Lacan para abordar como os registros do imaginário, do simbólico e do real são enodados, não sendo registros que se constituem isoladamente. Ao contrário, o nó borromeano tem como estrutura um amarramento tal que se um de seus anéis são rompidos, os demais se desenlaçam. As interseções entre um registro e outro também apontam que um registro não se constitui sem os outros resgistros.
}

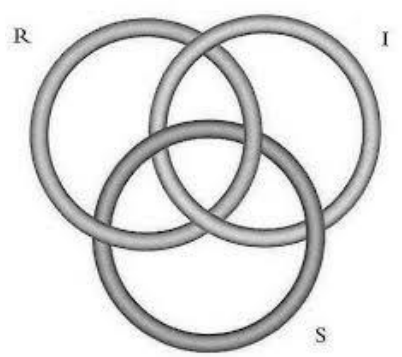

http://www.scielo.br/pdf/agora/v13n1/03.pdf

Recuperado em 14 de março de 2016, de

${ }^{34}$ Nesse momento, Lacan não havia elaborado formalmente a diferenciação entre o outro e o Outro. 
não se trata de outro, mas sim da imagem que ela tem do outro e, no terceiro, ela conclui que aquela é sua imagem". A criança experimenta o corpo como despedaçado e ao passar pelos tempos do estádio do espelho, ela pode organizar a imagem de seu corpo. Se Freud (1923/1996e) aponta que o eu é corporal, Lacan diz que o eu é imaginário e toma uma forma, a qual tem efeitos no organismo ao desnaturá-lo, pelo efeito do significante, processo que não ocorre nos animais.

Lacan (1998d) sinaliza que o ato de se ver no espelho repercute na criança gestos no qual ela experimenta de forma lúdica e um gesto de interpretação sobre a relação dos movimentos da imagem com o seu meio refletido, sobre a imagem virtual que reduplica a realidade mas a invertendo, sobre a relação com o próprio corpo e com as pessoas, os objetos que estejam nas imediações. Conforme o psicanalista francês, o estádio do espelho pode ser compreendido como uma identificação, no sentido da “[...] transformação produzida no sujeito quando ele assume uma imagem [...]” (p. 97). Para Lacan (1998d), a assunção jubilatória presente no encantamento com a imagem, carrega a matriz simbólica a partir da qual o eu ganha o contorno de uma forma primordial, que antecede a dialética da identificação com o outro/Outro no Complexo de Édipo, e antecede o lugar de sujeito.

A criança, então, antecipa numa miragem a maturação de sua imagem, que lhe é fornecida como Gestalt, como forma supostamente total pelo espelho, via exterioridade. Lacan (1998c, p. 98) diz que “[...] a imagem especular parece ser o limiar do mundo visível, a nos fiarmos na disposição especular apresentada na alucinação e no sonho pela imago do corpo próprio [...]". A função do estádio do espelho é estabelecer uma relação do organismo com a realidade, uma relação do Innenwelt com o Umwelt. Conforme Soler (2001), segundo esta concepção, “[...] quando se diz 'eu tenho um corpo', o Um do corpo - o que faz com que digamos o corpo Um - é o Um de uma imagem [...]”. Conforme Lacan (1998d, p. 100),

Esse desenvolvimento é vivido como uma dialética temporal que projeta
decisivamente na história a formação do indivíduo: o estádio do espelho é um
drama cujo impulso interno precipita-se da insuficiência para a antecipação -
e que fabrica para o sujeito, apanhado no engodo da identificação espacial, as
fantasias que se sucedem desde uma imagem despedaçada do corpo até uma
forma de totalidade que chamaremos ortopédica - e para a armadura enfim
assumida de uma identidade alienante, que marcará com sua estrutura rígida
todo o seu desenvolvimento mental. Assim, o rompimento do círculo do
Innenwelt para o Umwelt gera a quadratura inesgotável dos arrolamentos do
eu.

Partindo dessa afirmação, podemos dizer que a criança antes de dominar sua coordenação motora, como diz Soler (2001), não sabendo que seus pés são seus pés, que suas 
mãos são suas mãos, encontra na imagem refletida no espelho, a unidade que falta a seu organismo. Assim, “[...] a hipótese é que a representação Una da forma do corpo traria o Um que falta ao organismo prematuro e despedaçado [...]" (p. 9). Podemos, desse modo, inferir uma associação com o que Orlandi (2007a) aponta sobre o "um" como uma suposta unificação importante pois traz a diferenciação, ou seja, o que é um, o que é outro, e seguindo nas palavras de Soler (2001), o que é pé, o que é mão etc. O espelho possibilita, então, à criança uma forma em seu despedaçamento. Forma ${ }^{35}$ que retorna em todo o percurso do sujeito seja na representação da totalidade do corpo seja em seu despedaçamento, posto que é uma estrutura imaginária do eu na relação com o corpo, que retorna. Forma que nada tem de realidade, haja vista a relação da anoréxica com sua imagem (Bidaud, 1998), haja vista a relação dos amantes dos gadgets, ávidos por um novo objeto tecnológico para compor seu corpo, conforme vimos com a notícia "Homem mais conectado do mundo usa 700 sensores no dia a dia".

O sujeito, conforme Corrêa (2011, p. 62), é pura heterogeneidade, e o espelho faz um conjunto homogêneo de heterogeneidades. $\mathrm{O}$ autor assinala que quando a criança se olha no espelho ela é pura heterogeneidade, ela é despedaçada, fragmentada, contudo, na imagem que vê no espelho, ela vê um conjunto homogêneo, uma criança unificada. Sendo assim, a imagem especular faz um conjunto, um conjunto de uma pseudo-homogeneidade com o qual a criança vai se identificar, também dentro de uma função de desconhecimento. Inicialmente, a criança imagina que a criança do espelho não é ela e que a criança do espelho por ela se interessa, que a olha. O espelho antecipa para a criança uma imagem que ela não tem de si, e que a partir desse momento passa a supor como será, um tempo de "futuro anterior". A imagem do espelho antecipa um conjunto homogêneo para a criança que é heterogênea. A função visual antecipada às demais funções do corpo, antecipa para a criança uma suposta imagem total, e Lacan (1998a) afirma que a identificação da criança com a forma total da imagem de seu corpo é realizada a olho.

Relembremos que Lacan toma o espelho como metáfora, posto que essa relação se dá inicialmente também entre a criança e o corpo daquele que lhe cuida e, não somente com o objeto espelho. Retomando o que Lacan aponta sobre o estádio do espelho ser uma operação realizada a olho, apontamos com Bidaud (2014, p. 17, tradução nossa) que o sujeito é capturado pela imagem do rosto desde as primeiras horas de vida.

Desde as primeiras horas de vida, o recém-nascido se mostra capaz de dirigir seu olhar para o rosto materno, de distinguí-lo e de atraí-lo e retê-lo. É também notável seu interesse específico pelo rosto humano em vez dos objetos

\footnotetext{
${ }^{35}$ Veremos logo mais as formas do objeto $a$ (Lacan , 2005).
} 
inanimados que se encontram ao seu redor, interesse que evolui para um vivo interesse à olhar o outro e a se fazer ser olhado pelo outro. Assim as primeiras trocas mãe-bebê constituem o que nós nomeamos o acontecimento jubilatório dos rostos $[\ldots]^{36}$.

O referido autor aponta que na troca de olhares e da escuta da voz da mãe, no início da relação mãe-bebê, há um primeiro elemento de estrutura que situa a visão do rosto não como um reconhecimento do corpo próprio, porque esse reconhecimento só se constitui com o estádio do espelho, mas como uma primeira matriz do acontecimento "rosto", porque já se estabelece algum espelhamento, por meio da troca de olhares e da voz do outro/Outro, o cuidador, a própria linguagem. Bidaud (2014) supõe uma experiência originária com a imagem do rosto como uma das primeiras inscrições do sujeito, o que apontamos como importante para pensarmos na convocação do olho e do olhar em outros impasses do sujeito com o Outro, como no caso do estádio do espelho, constitutivo do eu, de uma suposta unidade corporal que equivalha a um todo. Assim, apresentamos, com esse autor, que a reação de interesse da criança diante do rosto é extremamente precoce. E mais, que o olho e a voz não são objetos quaisquer, tomam a forma de objetos parciais, como veremos.

O estádio do espelho instala a experiência do rosto como fundação de uma visibilidade compartilhada, ou seja, eu acedo ao "meu" rosto apenas na medida em que o rosto do Outro é objeto do meu próprio olhar e assim se instala esse "entrelaçado" do que olha e do que é visível, é ao menos dois sujeitos em toda visibilidade onde se misturam em um tempo comum o ver e o ser visto, mas também o dizer e o que é escutado. A experiência do espelho reenvia à dimensão escópica e invocante do dispositivo especular. Quer dizer que o corpo da criança só toma forma e consistência pela presença em reconhecimento do visível pela voz desse Outro que está ao lado. É a mãe que traz ao seu filho, na alegria de nomear o que ela vê, a marca de uma existência que aqui toma rosto pleno. Os clínicos não cessaram de ligar o momento especular a esse movimento de retorno da criança para o que vai fazer rosto no lugar do Outro. (Bidaud, 2014, p. 16, tradução nossa) ${ }^{37}$.

\footnotetext{
${ }^{36}$ Depuis les premières heurs de vie, le nouveau-né se montre capable de diriger son regard vers le visage maternel, de le distinguer et de s'y accrocher. Est aussi remarquable son intérêt spécifique pour le visage humain plutôt qu'aux objets inanimés qui se trouvent autor de lui, intérêt qui évolue vers un vif intérêt à regarder l'autre et à se faire regarder par l'autre. Ainsi les premiers échanges mère-bébé constituent ce que nous nommerons l'événement jubilatoire des visages [...]

${ }^{37}$ Le stade du mirroir instale l'expérience du visage comme fondation d'une visibilité partagée, c'est-à-dire que j'accède à mon visage que pour autant que le visage de l'Autre est objet de mon propre regard et qu'ainsi s'installe cet 'entrelacs' du voyant et du visible, cet au moins deux sujets de toute visibilité où se mêlent dans un temps commun le voir et l'être vu mais aussi le dire et l'entendu. L'expérience du mirroir renvoie à la dimension à la fois scopique et invoquante du dispositif spéculaire. C'est-à-dire que le corps de l'enfant ne prendre forme et consistance que par la présence em reconnaissance du visible par la voix de cet Autre à côté. C'est la mère qui apporte à son enfant dans la joie de nommer ce qu'elle voit la marque d'une existence qui ici prend pleinement visage. Les cliniciens n'ont eu de cesse de lier le moment spéculaire à ce mouvement de retournement de l'enfant vers ce qui va faire visage à l'endroit de l'Autre. (Bidaud, 2014, p. 16).
} 
O autor então assinala que, à visão, se associa a voz do Outro, contornando o corpo da criança que se olha no espelho, apresentando o simbólico no enlaçamento ao imaginário e também o real do gozo que pulsa no corpo (haja vista o quanto a criança repete a experiência do espelho até em brincadeiras como de se esconder do outro, do outro se esconder dela, encontrar, ser encontrada) avivado pelo desejo. Sobre o estádio do espelho, Lacan (1995) ainda reitera que "[...] Ele ilustra o caráter de conflito da relação dual. Tudo o que a criança aprende nessa cativação por sua própria imagem é, precisamente, a distância que há de suas tensões internas, aquelas mesmas que são evocadas nessa relação, à identificação com essa imagem. [...]” (p. 14). Podemos dizer então, que se o estádio do espelho concebe uma unidade corpórea, ressoa no sujeito o desencontro, ou ainda o que Lacan (2003b, 2003d) aponta: "a relação sexual não existe", ilustrando a não equivalência entre a imagem e o sujeito, e ainda entre o sujeito e o Outro, ademais, os impasses do sujeito com o desejo, com a falta, com aquilo que lhe escapa a ver/olhar, a dizer, a ouvir/escutar.

Mais adiante em seu ensino, n' "O seminário, livro 10, a angústia”, Lacan (2005) vai abordar que, embora (supostamente) o espelho suporte a totalidade de um corpo, ele só o faz de maneira parcial, posto que nem tudo é visto no espelho, há algo que resta (ao olhar), nem tudo é investido no espelho. Todavia, o sujeito estabelece uma relação com o ideal do eu e o eu ideal, perpassando uma imagem, à qual se enlaça na tentativa de encontrá-la. Tal ideal coincide com o que Payer (2005) assinala sobre a busca de um ideal atrelado ao poder do Mercado, este funcionando como Outro, como Sujeito, ao qual o sujeito se identifica. Fazendo avançar as questões apresentadas, Lacan (2005, p. 49) diz: “O investimento da imagem especular é um tempo fundamental da relação imaginária. É fundamental por ter limite. Nem todo investimento libidinal passa pela imagem especular. Há um resto [...]”. E continua “[ ...] o $a$, que é o resto, o resíduo, o objeto cujo status escapa ao status do objeto derivado da imagem especular. [...]" (p. 50). "Esse objeto $a$, [...] é sempre dele que se trata quando Freud fala de objeto a propósito da angústia [...]” (p. 50). No objeto $a$ está o encontro com o estranho e o familiar que habitam o ser falante. A tal objeto, se associam os objetos pulsionais - seio, fezes, pênis, ou, os objetos parciais, como Lacan (2005) os chama, acrescentando o olhar e a voz. Objetos que o sujeito elege ao longo de sua vida para lidar com a falta, o desejo e o gozo. "Associam-se" porque não há representação para o objeto $a$, porém o sujeito se vale de algumas formas para tentar capturálo. Tais formas são permeadas pelas pulsões - sempre parciais, posto que não abarcam o objeto - anal, oral, fálica, escópica (olho/olhar) e a invocadora (voz). Pulsões que contornam os furos do corpo. 
Segundo Soler (2001), n’ “O seminário, livro 22, RSI”, Lacan retoma sua afirmação de que o imaginário é o corpo e que o corpo depende do imaginário. Porém, infere que o imaginário não designa somente a imagem, a representação; o imagináro tem uma consistência real, que é a consistência de uma forma. A partir da experiência analítica, o psicanalista francês percebe que no adulto comparece um despedaçamento que nada tem de imaginário, e, portanto, ele inverte sua concepção do estádio do espelho.

Então, ali onde ele colocava do lado do real o despedaçamento doloroso e a unidade pacificadora do lado da imagem, ele vem a afirmar, exatamente, o contrário: Do lado do real, existem as coesões funcionais do organismo - e de fato, salvo caso de doença, o organismo tem a sua coesão funcional quase automática, de tal forma automática que se esquece que nosso organismo funciona. É apenas a doença ou o gozo que atrai a nossa atenção. Do lado do corpo ele coloca o despedaçamento, um corpo que manifesta um efeito... digamos, de cisalha no funcionamento; cisalha do pensamento do obsessivo, cisalha que recorta a anatomia fantasmática da histeria. Tudo isso é o do organismo funcional, um corpo que não tem nada de animal: é o corpo sintomático. Então, os sonhos, as fantasias, as imaginações, representam o corpo despedaçado. O importante é que eles o representam porque o despedaçamento não está, apenas, na representação. Ele está, de início, no sintoma, a cisalha do pensamento, a cisalha do corpo histérico. Mas ele está, também, e este é o ponto capital, nas pulsões. Encontra-se - e foi Freud que levantou isto - nas pulsões parciais, o despedaçamento do múltiplo, bem oposto às integrações unificadoras do instinto animal. Encontra-se, também, o recorte sobre a superfície do corpo das zonas erógenas - é um outro corte e depois, ainda, o corte entre os objetos pulsionais e a função orgânica correspondente. Todos estes fatos sobre os quais retornaremos mostram o que Lacan chamou "le jeu da la coupure" (o jogo do corte) [...] (p. 10).

A partir desses apontamentos, trazemos uma das obras de Picasso que faz reverberar o despedaçamento do corpo, o qual retorna, no discurso, e que comparece no olhar do artista. Não é por acaso que Freud (1908 [1907]/1996c) apontava que os poetas e os pintores antecederam os psicanalistas na escuta ao humano. Trazemos a questão do despedaçamento e a questão da unidade imaginária do corpo posto que essas questões comparecem nos discursos que analisamos sobre a relação sujeito, corpo e objetos tecnológicos de conexão à rede eletrônica, relação na qual o objeto é tomado como aquele que ao se acoplar a partes do corpo, dispensam outras partes do corpo, discursivamente as alocando como desnecessárias, comparecendo um corpo que se despedaça no discurso, ao supostamente se completar com o objeto tecnológico potente, compondo a forma de um corpo que tudo pode no virtual. Interessa-nos, portanto, dedicar escuta a esse movimento de despedaçamento-totalidade que comparece imaginariamente na concepção de ciborgue, que abordamos anteriormente. 


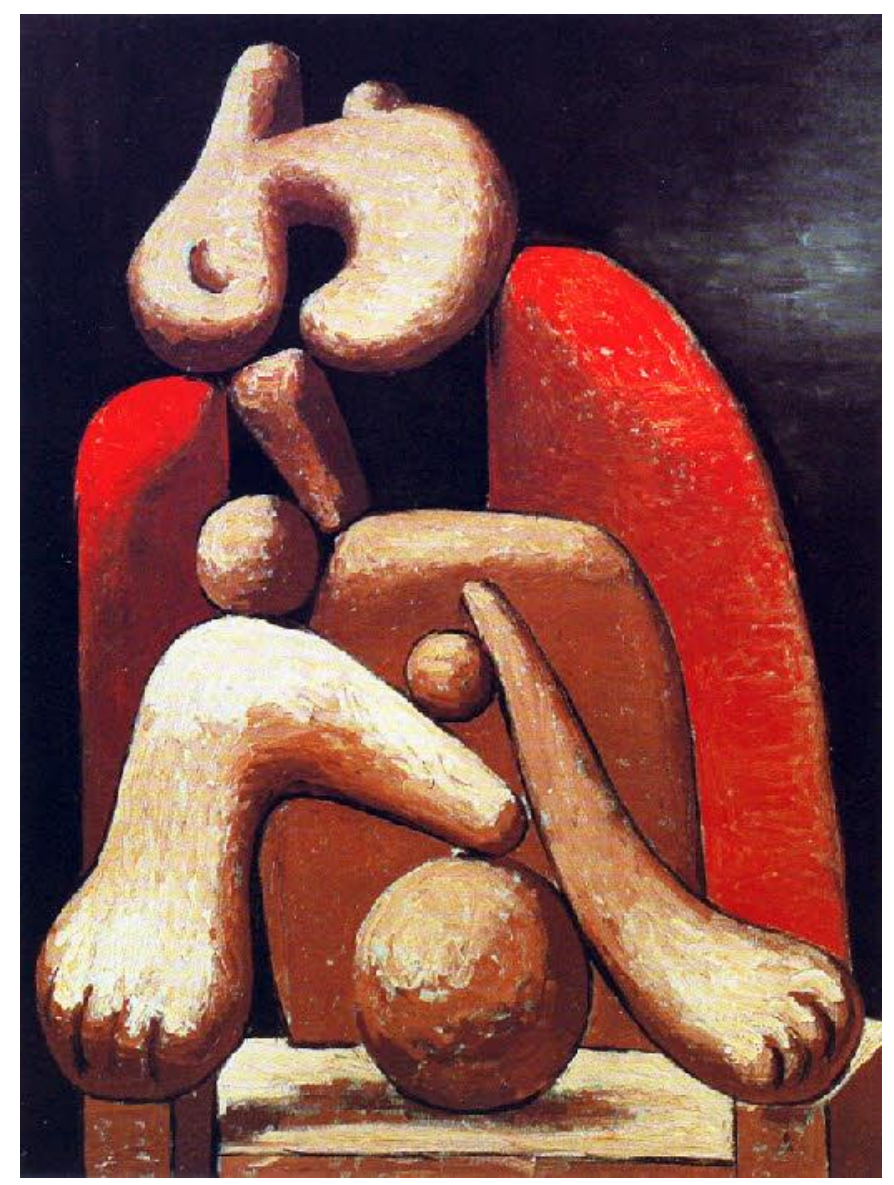

Figura $16^{38}-$ Femme au fauteuil rouge (Picasso, 1932)

Como Soler (2001) afirmou, o despedaçamento está nas pulsões, está no recorte da superfície do corpo nas zonas erógenas, nos contornos dos furos, está no corte dos objetos pulsionais/parciais e em relação à função orgânica que lhes correspondem. Dentre os objetos parciais, destacaremos aqui o objeto olhar, porque temos escutado o quanto o discurso mercadológico tem investido em objetos tecnológicos que visam ao olho, à visão e ao olhar. Lacan (1998e) aponta uma esquize do olho e do olhar, na qual é manifestada a pulsão escópica, no sentido de "[...] distinguir a função do olho da função do olhar" (p. 75). Segundo o psicanalista francês, a função do olhar é o que comanda mais secretamente, e é ao mesmo tempo o que escapa da apreensão da visão que se imagina como consciência. Abordando o livro de Merleau-Ponty, “O visível e o invisível”, Lacan (1998e) aponta o fato de que somos seres olhados pelo mundo, o mundo é onivoyer, mas não nos damos conta disso. Explica, assim, que é por isso que somos capazes de sentir vergonha ainda que ninguém esteja olhando, pois supomos um olho que tudo vê. Tal apontamento, torna-se importante para pensarmos sobre a produção de objetos tecnológicos de conexão à rede eletrônica que proporcionam a realidade

\footnotetext{
${ }^{38}$ Recuperado em 27 de outubro de 2015, de http://kerdonis.fr/ZPIC02/page2.html
} 
aumentada como uma possibilidade do olho tudo ver, a possibilidade suposta de "nada mais escapar aos olhos" ${ }^{39}$, compondo um olho onivoyer, mais um movimento na busca da completude, resvalada no "sentimento oceânico" (Freud, 1930/2010) ou ainda em "Das Ding". Lacan (1998d) afirma que, na vigília, a função do olhar é elidida, elisão de que isso olha e que isso mostra, e para isso ilustrar, ele recorre aos sonhos, posto que o olhar está associado ao inconsciente. Sublinha que o olhar pode conter o objeto $a$, "[...] na medida em que o olhar, enquanto objeto $a$, pode vir a simbolizar a falta central expressa no fenômeno da castração, e que ele é objeto $a$ reduzido, por sua natureza, a uma função punctiforme, evanescente - ele deixa o sujeito na ignorância do que há para além da aparência [...]” (p. 77). É justamente esse o efeito do sonho, a priori, já que ele se apresenta por uma composição de imagens, conteúdos e narrativas que se sobrepõem, indiciando a falta, a castração. Também aí vemos se acoplar os objetos tecnológicos de conexão à rede eletrônica que se apropriam do olho prometendo ver as imagens do mundo virtual "até de olhos fechados" ${ }^{40}$, função possível até então nos sonhos. Porém, a categoria do olhar não se deixa apreender na totalidade.

O psicanalista francês faz uso da anamorfose na pintura para diferenciar também o olhar da visão, pela armadilha do olhar, e ilustra isso com o quadro "Os embaixadores" de Hans Holbein, que expomos a seguir.

\footnotetext{
${ }^{39}$ Recuperado em 15 de agosto de 2013, de http://blogs.estadao.com.br/link/nada-mais-escapa-aos-olhos-e-aslentes-com-o-google-glass/

${ }^{40}$ Recuperado em 23 de março de 2013, de

htto://www.inovacaotecnologica.com.br/noticias/noticia.php?artigo=lentes-contato-inteligentes-projetaraoimagens-retina\&id=010150110117\#.U6iznfldVn4
} 


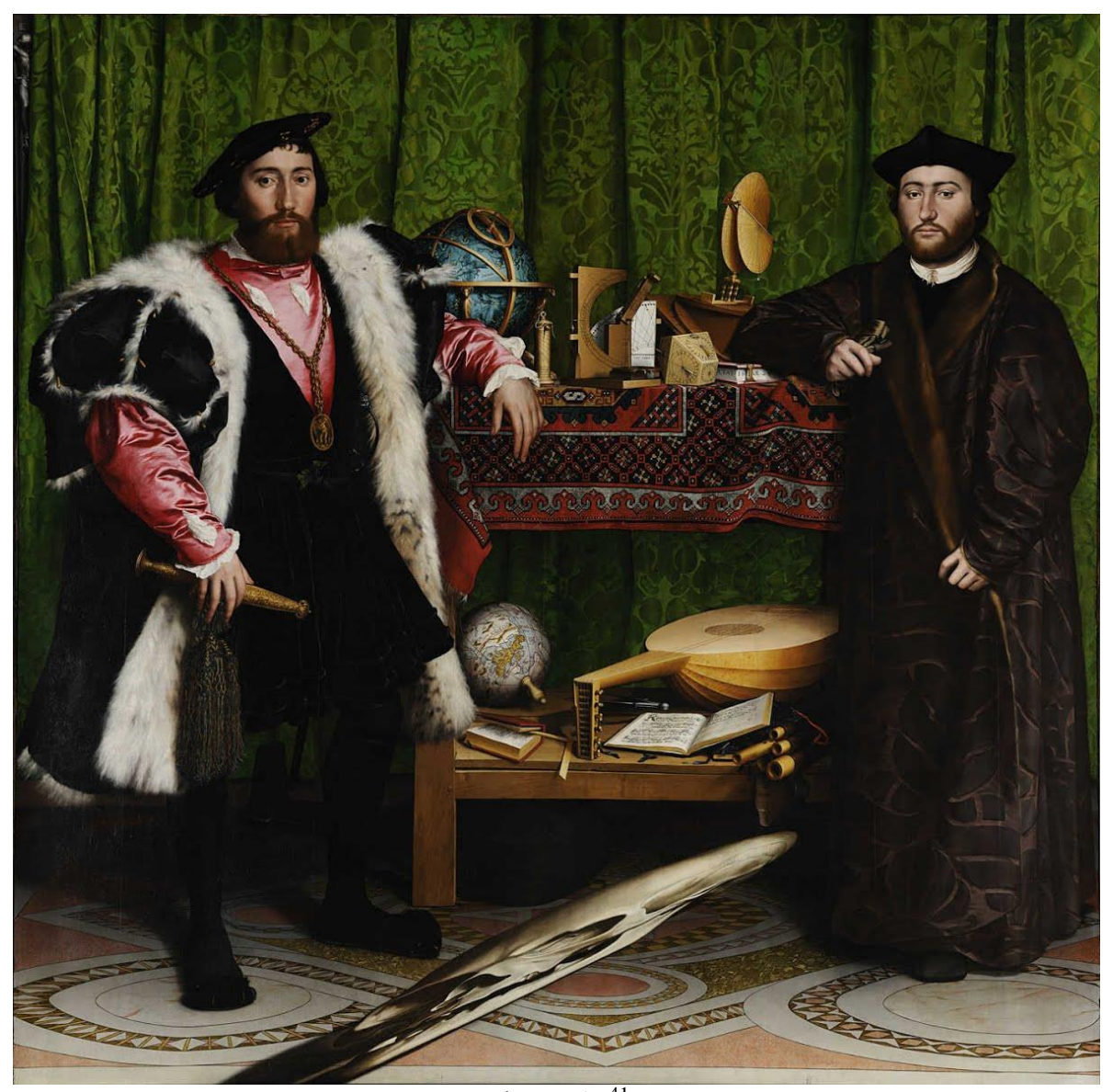

Figura $17^{41}$

Para abordar sobre a função do olho, Lacan (1998e) afirma que "A relação do sujeito com o órgão está no coração de nossa experiência. Entre todos os órgãos com que lidamos, o seio, as fezes, e outros ainda, há o olho [...]” (p. 90). E vai dizer como a partir da dimensão geometral, que ele explica por meio da anamorfose no quadro "Os embaixadores" (como dissemos), o sujeito fica preso no campo da visão. O segredo do quadro está no momento em que nos afastando dele vemos o crânio de uma caveira ao invés de um objeto flutuante. Por esse meio, Lacan (1998e) explica que quando estamos muito próximos do quadro, ele nos puxa para dentro dele e não vemos o crânio. Também aponta uma história vivida por ele, na qual um pescador ao avistar uma lata de sardinha na água diz a Lacan: "Tá vendo aquela lata? Tá vendo? Pois ela não tá te vendo não!” (p. 94). Lacan (1998e), articulando a linha e a luz, diz que a lata o olha, ela não o vê, mas, pelo ponto luminoso e pela linha de luz a lata se pinta no fundo do olho de Lacan. E, assim, o olha. O psicanalista faz uma importante diferenciação entre o olho, a visão e o olhar, que é muito cara a essa pesquisa porque convoca o nosso olhar para a relação

\footnotetext{
${ }^{41}$ Recuperado em 20 de janeiro de 2015, de https://www.google.com/culturalinstitute/asset-viewer/theambassadors/bQEWbLB26MG1LA?utm_source=google\&utm_medium=kp\&hl=pt-BR\&projectId=art-project
} 
sujeito, corpo e objetos tecnológicos de conexão à rede eletrônica, para além do órgão olho e da função do ver que dele é convocada na relação com os objetos a que nos referimos.

Lacan (1998e) coloca a questão do que é o olho como órgão e diz que as “[...] funções do olho não esgotam o caráter do órgão no que ele surge sobre o divã [...]” (p. 100). O psicanalista freudiano aponta então a relação ao falo e afirma que na dialética do olho e do olhar não há coincidência, mas sim logro. Pontua que quando no amor é pedido um olhar, o que há de insatisfatório e falhado que aparece na voz do sujeito é "Jamais me olhas lá de onde te vejo" e "o que eu olho não é jamais o que quero ver." (p. 100), o que Lacan (1998e) associa com a relação do pintor e do aficionado, que se passa num jogo de trompe-l-oeil, jogo usado na pintura que causa a "tapeação do olho". E assim afirma o triunfo do olhar sobre o olho. Abordando a questão da falta, do olhar e do objeto $a$, Lacan (1998e, 101-102) afirma:

No nível da dimensão escópica, na medida em que a pulsão aí esteja em jogo, se reencontra a mesma função do objeto a que é discernível em todas as outras dimensões.

O objeto a é algo de que o sujeito, para se constituir, se separou como órgão. Isso vale como símbolo da falta, quer dizer, do falo, não como tal, mas como fazendo falta. É então preciso que isso seja um objeto - primeiramente, separável - e depois, tendo alguma relação com a falta. Vou já encarnar para vocês o que quero dizer.

No nível oral, é o nada, no que aquilo de que o sujeito foi desmamado não é nada mais para ele. Na anorexia mental, o que a criança come é o nada. Vocês percebem, por esse viés, como o objeto do desmame pode vir a funcionar, no nível da castração, como privação.

O nível anal é o lugar da metáfora - um objeto por outro, oferecer as fezes no lugar do falo. Aí vocês percebem porque a pulsão anal é o domínio da oblatividade, do dom e do presente. Lá onde somos pegos desprevenidos, lá onde não podemos, por motivo da falta, dar o que temos que dar, temos sempre o recurso de dar outra coisa. É por isso que, em sua moral, o homem se inscreve no nível anal. E isto é verdadeiro muito especialmente quanto ao materialista.

No nível escópico, não estamos mais no nível do pedido, mas do desejo, do desejo do Outro. É o mesmo no nível da pulsão invocadora, que é mais próxima da experiência do inconsciente.

De maneira geral, a relação do olhar com o que queremos ver é uma relação de logro. O sujeito se apresenta como o que ele não é e o que se dá para ver não é o que ele quer ver. É por isso que o olho pode funcionar como objeto $a$, quer dizer, no nível da falta $(-\varphi)$.

Afirma ainda que no dado-a-ver há uma espécie de desejo ao Outro e que há um apetite do olho naquele que olha. Essa questão do apetite do olho torna-se importante para realçarmos questões sobre a visibilidade, a qual já abordamos com Debord (2003) no campo social, de uma sociedade que se volta ao espetáculo, e, nesse momento, com Lacan (1998e), podemos apontar as questões do sujeito no campo do olho e do olhar, campo de logro, de castração, no qual aquilo 
que é ofertado não é bem o que o sujeito quer ver, posto que não há objeto que supra a falta. Podemos dizer que o poder do mercado (Payer, 2005), o discurso do mercado (Braunstein, 2010), então, aí se alia, provocando o logro, provocando a busca do sujeito ao engodo do "servomecanismo" (Braunstein, 2010). Para articularmos alguns breves pontos com o que psicanalista francês delineia sobre o olho, a visão e o olhar, trazemos uma imagem recortada da notícia "Já pensou em usar a internet pelo espelho do banheiro", que aborda o espelho cibernético analisado no capítulo 2 .

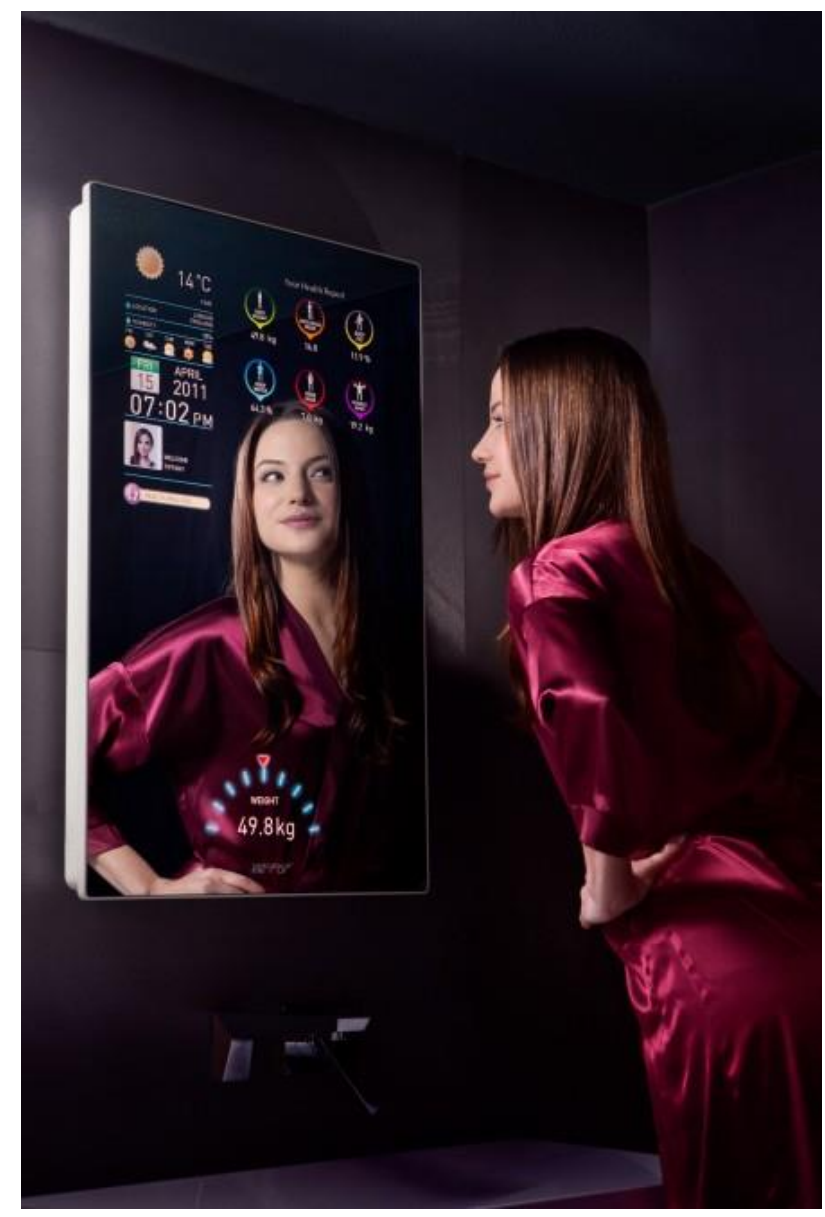

Figura $18^{42}$

Recortamos essa foto porque ela nos faz articular questões importantes trazidas por Lacan (1998e) sobre o olho e o olhar. Destacamos, inicialmente, no mínimo seis olhos capturados na foto, quais sejam: 1) o olho da modelo que faz a cena. 2) o olho da modelo refletido no espelho, e que a olha. 3) o "olho" da máquina fotográfica que captura a cena. 4) o

\footnotetext{
${ }^{42}$ Recuperado em 20 de novembro de 2012, de http://info.abril.com.br/noticias/blogs/gadgets/miscelanea/japensou-em-usar-a-internet-pelo-espelho-do-banheiro/
} 
olho do fotógrafo que captura a cena para provocar o nosso olho. 5) o olho de nós, observadores. 6) e, se assim podemos dizer, como no exemplo da lata de sardinha, o "olho" do objeto espelho. Ainda podemos trabalhar também com outro olho/olhar, o olho do mundo, como disse Lacan (1998e), já que o mundo é onivoyer, nos observa. Tentaremos trabalhar com esses olhos e esses olhares numa perspectiva faltante em que caiba sempre um outro gesto de interpretação, preservando a falta característica do campo do olhar, e também do olho, já que pela sua própria constituição, enquanto órgão, lhe é impossível tudo ver, ver tudo; lhe é impossível inclusive ver aquele que o porta, ou seja, é impossível enxergar-nos a nós mesmos com nosso olho sem um anteparo que nos reflita. Talvez o espelho capture o olho naquilo que lhe falta a ver. E o eu se engana, como se o que faltasse a ver fosse apenas a imagem refletida, a imagem supostamente completa, que é castrada de saída posto que é invertida e oculta a parte do corpo que nele, espelho, não caiba, ou que a ele não seja mostrada, sendo esse objeto também castrado. É a tapeção do olho. Ou seja, não há uma visão total, embora haja um efeito de completude no sujeito que olha. É isso que o olho/visão aponta. Tentaremos não ficar presos no campo da visão, ainda que nela nos pautemos para nossa análise.

Abordamos, então, a foto, em que de um lado comparece a modelo clicada em ângulo posterior-lateral, e do outro, a imagem refletida no espelho, na qual comparece a imagem da modelo, invertida e dando a ver a parte frontal do corpo e do rosto, que ficam fora de nosso campo visual, mas no campo visual do espelho a ponto de refleti-la. Da mesma forma em que parte do corpo e do rosto da modelo ficam fora de nosso campo visual e se refletem no espelho por estarem no campo visual do espelho, uma parte do corpo da modelo não se reflete no espelho, como a parte da cintura pra baixo, por estar fora do campo visual do espelho, mas, podemos vê-la por estar no nosso campo de visão. Estamos, assim, expondo a parcialidade do campo do olho e do olhar, trabalhando com o olho/olhar como objeto parcial elencado por Lacan (1998e) no campo do desejo, ou seja, com a pulsão escópica. Estamos também trabalhando com a parcialidade do objeto espelho, que, no entanto, faz semblante de completude para que o eu se constitua no virtual e dali possa advir um sujeito e corpo de linguagem.

Passamos a um outro momento em que apontamos a captura de olhares entre a modelo, que olha o espelho, e a imagem da modelo refletida no espelho, que retorna o olhar para a modelo. Nesse jogo de olhares, podemos ilustrar o que Bidaud (2014) aponta sobre o rosto como a primeira relação de espelhamento, no qual o olho e o olhar já são convocados como uma experiência do objeto parcial da pulsão escópica. Tanto na primeira relação de espelhamento quanto no estádio do espelho em si e nos arrolamentos posteriores do eu e do sujeito com o outro/Outro/espelho, podemos destacar o júbilo de completude com a imagem. 
Nessa imagem, podemos destacar ainda a função que esse espelho cibernético exerce enquanto voz, pulsão invocante, e significante na medida em que fornece dizeres sobre o sujeito, na medida em que compõe uma cena em que anuncia algo sobre o corpo, como por exemplo, que se trata de um corpo de 49,8 $\mathrm{kg}$ aquele que se apresenta, parcialmente, na imagem refletida. Não é um corpo qualquer, é um corpo que se adequa aos padrões de beleza de uma época, o corpo-imagem materializado por esse objeto tecnológico de conexão à rede eletrônica, é um corpo consumidor de tecnologia, é um corpo que responde, nesse caso, ao discurso do mercado (Braunstein, 2010) e aos enunciados do mercado (Payer, 2005), identifica-se a forma-sujeito do discurso. Nesse gesto de interpretação que empreendemos, podemos destacar o quanto o discurso que sustenta os objetos tecnológicos de conexão à rede eletrônica se acoplam aos modos de constituição de sujeitos e sentidos, ofertando imagens de completude, que atendem ao júbilo, ao encantamento com a imagem e com o objeto tecnológico. Objeto que se oferta na sombra do objeto $a$, aquele que causa o desejo. Como vimos no capítulo 2 , o objeto $a$ não existe materialmente, mas objetos se arrolam a fazer dele objetos parciais, como os objetos parciais olho, voz, fezes, seio, falo. Apontamos que a produção de objetos tecnológicos tem se enlaçado aos objetos que fazem fascínio ao sujeito para fisgá-lo na ilusão de completude.

Nessa leitura, ainda cabe ressaltar que essa cena é produzida pelo olho fotográfico e pelo "olho" do marketing, os quais nos permitem ver essa cena, que é clicada e colocada à mostra aos olhos consumidores. Os olhos convocados a observarem à cena-produto, são expostos à identificação com a imagem, identificação à imagem do espelho bem delineada por Lacan (1998d), olhos supostos serem fisgados por essa cena que nada mais é do que a venda de um produto. Tirando a nossa venda, e olhando com outros olhos, pudemos apontar a opacidade da cena. A imagem refletida no espelho (e na nossa retina), fita, lança um olhar sedutor. Olhar que temos percebido no discurso sobre os objetos tecnológicos de conexão à rede eletrônica. $\mathrm{O}$ objeto nos olha. E nós lançamos a ele um olhar faltante, mas que olha e escuta nas entrelinhas, e que, se é norteado pela psicanálise, também o é pela Análise do Discurso, que ampara o nosso gesto de interpretação.

Feito o percurso por várias teorias, neste momento, apresentaremos a noção de corpo para a Análise do Discurso, que trabalha com a interpelação do corpo pelo discurso e sua constituição em meio às condições de produção. Amparadas nesta disciplina de interpretação, abordaremos o processo de produção de discursos sobre o corpo. 


\subsection{O corpo, segundo a Análise do Discurso}

Como já apontamos, Pêcheux não chegou a formalizar o corpo como um conceito, mas, em suas produções, são inúmeras as passagens em que ele se vale do "corpo" para abordar os conceitos que sustentam a Análise do Discurso. Dentre essas passagens destacamos:

De nada adianta negar essa necessidade (desejo) de aparência, veículo de disjunções e categorizações lógicas: essa necessidade universal de um 'mundo semanticamente normal', isto é, normatizado, começa com a relação de cada um com seu próprio corpo e seus arredores imediatos (e antes de tudo com a distribuição de bons e maus objetos, arcaicamente figurados pela disjunção entre alimento e excremento) (Pêcheux, 2008, p. 34).

Então o simbólico faz irrupção diretamente no corpo, as palavras tornam-se peças de órgãos, pedaços do corpo esfacelado que o "logófilo" vai desmontar e transformar para tentar reconstruir ao mesmo tempo a história de seu corpo e a da língua que nele se inscreve: essa "loucura das palavras", que pode desembocar na escrita (Rabellais, Joyce, Artaud ou Bechett), na poesia (Mallarmé) ou na teoria linguística, persegue sem trégua o laço umbilical que liga o significante ao significado, para rompê-lo, reconstruí-lo ou transfigurálo (Pêcheux, 2010, p. 45).

Sendo um objeto simbólico que clama por interpretação, muito se tem estudado sobre os contornos desse conceito no campo da Análise do Discurso por aqueles que a levam adiante. Nessa seção, traremos as produções de algumas autoras que têm trabalhado para a formalização do conceito referido, na interpretação de diversas materialidades discursivas que enlaçam o corpo na produção de sentidos na pós-modernidade. Dentre essas autoras, destacamos Orlandi (2012a, 2012b, 2014), Leandro-Ferreira (2013) e Dias (2008, 2011, 2012) - que já citamos nas seções anteriores -, Gallo e Romão (2011) e Azevedo (2013a, 2013b), que trazem importantes contribuições para a presente pesquisa.

É firmemente alicerçada no conceito de sujeito em Pêcheux (2009a), que Orlandi (2012b) assinala que “[...] A interpelação do indivíduo em sujeito pela ideologia produz uma forma sujeito histórica com seu corpo [...]” (p. 86). Assim, concebe o corpo como uma produção, decorrente da interpelação ideológica, e, acrescentamos, do inconsciente. A autora aponta que sujeito e corpo estão materialmente ligados pela via do discurso e não são indiferentes à história e à ideologia. Tal concepção perpassa o que apontamos sobre a historicidade do corpo, na qual discursos legitimados incidem na constituição dos sentidos e dos sujeitos, também constituindo corpos e discursos e olhares para o corpo em cada contexto 
sócio-histórico. Sendo o corpo também interpelado, para a via discursiva, ele não é apenas carne, ele é, sobretudo, “corpodiscurso" (Leonel, 2010), pois participa do processo de produção de sentidos e dele resulta, na medida em que é atravessado por formações ideológicas que determinam o que é e pode ser, em dadas condições de produção. É por isso que ele pode ser tomado como peça/interface da máquina, como potente, como descolado dos limites, e inclusive pode ser silenciado, via discurso.

Segundo Orlandi (2012b), a relação do sujeito com o corpo não é transparente, assim como não é transparente a sua relação com a linguagem, embora pelo efeito dos esquecimentos $\mathrm{n}^{\mathrm{o}} 1$ e $\mathrm{n}^{\mathrm{o}} 2$, sujeitos tomem os sentidos (sobre o corpo) como evidentes. A autora acrescenta que sujeitos e sentidos na formulação de discursos dão corpo à línguagem, ao mesmo tempo que “[...] se dão corpo na linguagem. Corpos são formulações dos sujeitos, em diferentes discursos. [...]” (p. 92). Dito de outro modo, o corpo é produzido pelo discurso e produz discurso. Interessa à Análise do Discurso o estudo de como o corpo se constitui em dado contexto e, ademais, em cada formulação discursiva, já que nem sujeitos nem corpos são evidentes, pois são atravessados por discursividade, por efeitos de sentido construídos na e pela memória, significando de diferentes modos, ainda que, assim como nossas palavras, o corpo já venha significado antes mesmo de o significarmos. No jogo da significação, o corpo é constituído na alteridade, produzindo-se na linguagem quando também a produz. Investigamos, portanto, o modo como o corpo é discursivizado a partir dos objetos tecnológicos de conexão à rede eletrônica, e de modo especial, a partir daqueles que prometem a realidade aumentada, pois o corpo não é discursivizado do mesmo modo, por exemplo, na dança, nas artes.

De acordo com a Orlandi (2012b), no processo de constituição do sujeito, atravessado pela forma-sujeito histórica capitalista, também o corpo é interpelado, e por isso ele pode ser tão afetado por nossa sociedade de consumo, de tecnologias de consumo. Acrescentamos a interpelação pela forma-sujeito histórica atrelada ao poder do Mercado, segundo Payer (2005), a qual incide no sujeito e no corpo enlançando-o ao mercado, e, também, ao produto. Nesse enlace, o corpo é discursivivizado como produto mercadológico em potência, (a ser) consumido(r), e sua faceta de produto de linguagem, faltante, é silenciada. Porém, como aponta Leandro-Ferreira (2013), ao retomar Pêcheux, de nada adianta negar e tamponar as falhas do corpo, as quais irrompem como vestígios do histórico no corpo. Orlandi (2012b) acrescenta, assim, que o corpo é, portanto, “[...] estruturado pelos modos de produção da vida material que condicionam o conjunto dos processos da vida social e política" (p. 95), sendo em cada contexto sócio-histórico discursivizado de um modo, como já apontamos. 


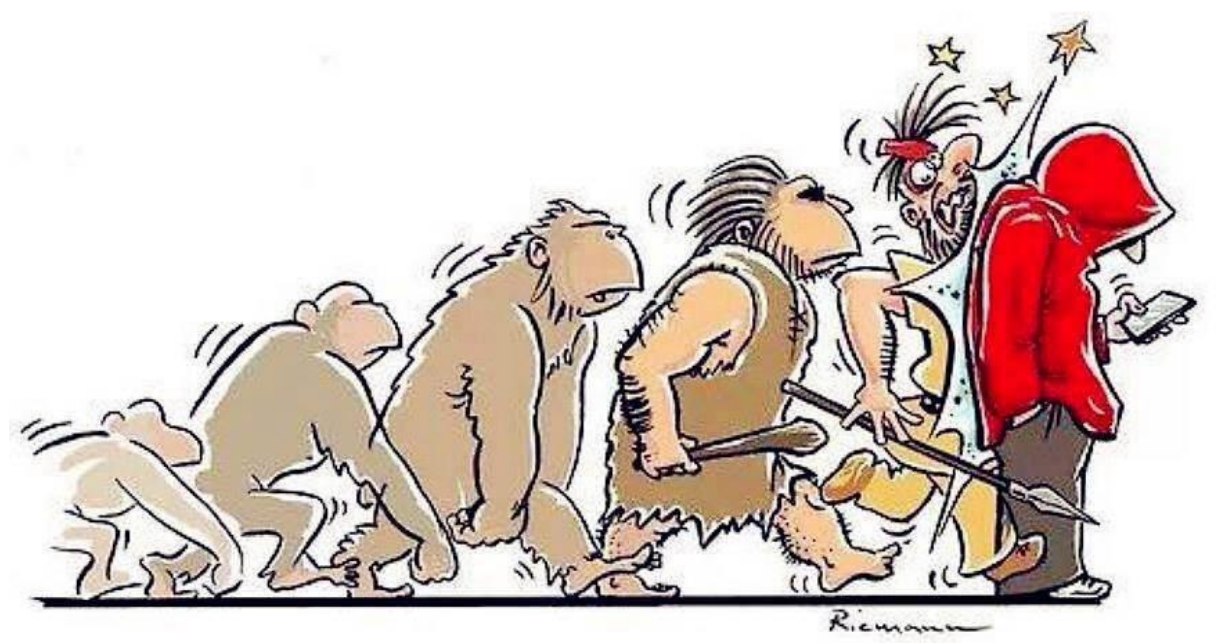

Figura $19^{43}$

Para articularmos o conceito de corpo delineado pelos autores, trazemos a Figura 19. Como dissemos, no campo da Análise do Discurso não consideramos que a cronologia incida produzindo sentidos, mas sim a historicidade, que é marcada pelo tempo e pelo discurso, já que o cronológico é apenas um marco que visa estabilizar sentidos, garantir um suposto controle dos sentidos. Ultrapassando a linha do controle e estabilização, expomos essa Figura à opacidade para tecermos um gesto de interpretação aos sentidos nela materializados e silenciados. Assim, apontamos que a sequência linear de corpos que se apresentam da direita para a esquerda, sinalizam, pela memória discursiva, os sentidos de evolução abarcados pelas ciências biológicas que indicam que o homem evolui do macaco. Podemos, então, apontar uma formação discursiva "evolutiva" à qual se filiam os sentidos nesta Figura.

Sinalizamos, portanto, sentidos de "evolução" na postura do corpo, que de curvada passa à ereta, deixando as mãos de amparar o caminhar, como vemos se esboçar no desenho do terceiro corpo, na medida em que o(s) corpo(s) prossegue(m) na linha temporal. Um passo e outro e outro adiante, e, desamparada de sua função no caminhar, as mãos ganham instrumentos, na medida em que também os produzem, e o corpo ganha vestimentas, passos marcados pela incidência da cultura: um corpo que se veste somado ao investimento em instrumentos que protegem o corpo dos três perigos que rondam o homem, como Freud (1930/2010) aponta: a fragilidade do corpo, a sua vulnerabilidade à natureza e o conflito nas

\footnotetext{
${ }^{43}$ Recuperado em 23 de abril de 2014, de http://freakout.net.br/evolucao-riemann/
} 
relações com os outros homens. Os sentidos de evolução prosseguem na medida em que os instrumentos são aperfeiçoados, da pedra lascada à pedra polida, e num salto tecnológico, as mãos manipulam um objeto tecnológico de conexão à rede eletrônica, seja ele um smarthphone, um tablet, um ipad ou qualquer variação que nomeie a tela e o sistema operacional. Assinalamos que nessa linha evolutiva, foram elididos diversos outros objetos tecnológicos criados pelo homem, entre a pedra polida e o objeto tecnológico de conexão à rede eletrônica, e, essa elisão pode vir a significar a instantaneidade com a qual esses objetos se proliferaram na "evolução" humana e tecnológica, da pré-história à pós-modernidade?

$\mathrm{Na}$ esteira evolutiva, a lança que servia para caçar, defender-se, emoldura-se em forma de objeto tecnológico de conexão que supostamente permite ao corpo navegar por onde quiser na rede eletrônica, não necessitando dar mais nenhum passo com seu corpo de carne, osso e discurso posto que o último corpo da linhagem histórica está com os pés fincados no chão, os olhos fixados na tela e o dedo a deslizar? Podemos então dizer que a linha evolutiva traz um efeito de fim na medida em que o corpo se apresenta paralisado, mas que a história prossegue no passo virtual? Podemos dizer que a formação discursiva evolutiva se aglutina com a formação discursiva mercadológica que propõe que a evolução do corpo e dos objetos tecnológicos é movida pelas redes?

Sobre o último corpo ilustrado, apontamos que ele se curva, não para as mãos tocarem o chão e auxiliar a locomoção, nem para os olhos ficarem mais próximos do sólo para facilitar o caminhar em meio hostil, mas para as mãos tocarem os links que se apresentam na tela, nas redes sociais e eletrônica e os olhos guiarem o gesto, fisgados em uma forma-sujeito, respondendo às demandas do mercado a partir de uma posição-sujeito que consome e é consumida, na qual o corpo, as partes do corpo se voltam para a relação com o objeto tecnológico. Nesse gesto de interpretação, assinalamos que os olhos se curvam para baixo para olhar o horizonte das redes, assim como os dedos clicam; assim como, para além de uma metáfora, a ilusão de que o corpo se move na rede. Indicamos também que a cabeça se curva diante do objeto tecnológico e da rede eletrônica, tal qual diante de outras materialidades representativas da ideologia dominante em cada contexto sócio-histórico, como o Livro Sagrado, a Constituição e agora a Mídia (Payer, 2005).

Destacamos, ademais, o choque entre o corpo que carrega o instrumento pontiagudo de pedra polida e o corpo que porta o objeto tecnológico de conexão à rede eletrônica. Choque no qual o corpo que sofre o abalo é o do que está um passo atrás. Levantamos então a questão: o corpo pós-moderno é inabalável quando o horizonte se torna a tela do objeto tecnológico e o que a rede eletrônica possibilita? O que sustenta esse inabalável está embebido nos discursos 
que sustentam que a potência do corpo se dá no colamento com o objeto tecnológico fazendo girar a máquina do mercado, na qual o corpo comparece como consumido(r)?

Apontamos, então, vestígios do histórico no corpo, como delineia Orlandi (2012b), efeitos do discurso que emoldura o corpo em cada contexto. E ainda, com a autora, podemos dizer que "Sabemos que as palavras, os gestos, os corpos são governados em sociedade e sentidos se traçam, nos trajetos sociais, percursos históricos. Filiam-se a memórias e submetemse a processos de estabilização. Organizam-se. [...]" (Orlandi, 2014, p. 83), em torno da necessidade de aparência e de normatização, como diz Pêcheux (2008, p. 34), que ganha novos contornos legitimados pelas filiações discursivas ao Mercado. O corpo estabilizado no chão, sem dar mais passos, ao passo que é movente na rede eletrônica poderá ser mais trabalhado com os conceitos que vamos abordar.

Dias (2008) formula o conceito de "corpografia" levando em conta o modo como o corpo se inscreve na escrita, no digital, tendo em vista que, nas relações mediadas pelos objetos tecnológicos de conexão à rede eletrônica, o corpo físico é impossibilitado de comparecer. Assim, a autora aponta como o corpo se materializa na escrita, tomando a língua como simulacro e não apenas como representação do pensamento, encontrando um meio para dar contorno ao impossível do corpo. Conforme a autora, o conceito de corpografia pretende problematizar a formulação do corpo inscrito como grafia, na medida em que a corpografia não representa uma emoção, mas sim a cria nas condições de produção específicas do uso do objeto tecnológico de conexão à rede eletrônica. “[...] O uso de símbolos como =P [...], é um exemplo de corpografia [...]" (p. 20). Desse modo, a corpografia é a “[...] textualização do corpo na letra. [...]” (p. 21), uma textualização que é inscrita via letra, mas que compõe não uma palavra, mas um desenho representativo do corpo. Se a voz já podia ser materializada pela letra, pela palavra e atravessar continentes por meio de cartas, hoje, com a materialidade eletrônica, no efeito de proximidade e instantaneidade, $\mathrm{o}$ corpo é materializado na letra como imagem corpográfica $=\mathrm{P}$, onde ele não pode comparecer.

Assinala que, se o modo como o discurso circula marca um modo de constituição do sujeito, a internet com sua linguagem própria cria um paradigma para pensarmos o sujeito em seu movimento histórico e social, em sua forma de escritura. A autora, circunscreve, então, o ato de escrever a uma tentativa de suturar uma perda, movido pelo impossível. Acrescenta que o sujeito inventa o internetês como um modo de contornar o impossível do corpo, da linguagem de programação, da língua e do corpo na língua. Sobre a especificidade da escrita na internet, acrescenta que a noção de espaço e tempo na rede incidem na escrita e refletem na sua abreviatura, que faz da escrita "estou feliz", a escrita corpográfica e econômica =P, como se o 
corpo pudesse circular na rede eletrônica juntamente com os demais dados. A autora enfatiza, então, que o real do corpo irrompe do impossível do corpo enquanto orgânico, materializandose como corpo gráfico.

Conforme Dias (2011), "Pensar que o corpo entra numa outra lógica, a da circulação, da virtualidade, do simulacro e da simulação é um caminho promissor para compreender os sentidos que vem sendo produzidos para o corpo a partir do desenvolvimento das novas tecnologias” (p. 24). Retomando a Figura 19, podemos apontar que cada instrumento que ocupa as mãos na linha evolutiva reverberam discursos sobre o corpo em cada contexto sóciohistórico. E, sobretudo, a respeito do último corpo com o objeto tecnológico de conexão à rede eletrônica em mãos, podemos sustentar o conceito de corpografia de Dias (2008), na medida em que há discursos que sustentam que o corpo se move na rede eletrônica, e esses discursos podem ser marcados até na própria não movência das pernas do corpo ao qual nos referimos. Trata-se de um corpo que se move supostamente em outro plano, na virtualidade, fazendo existir um corpo outro: corpográfico, um corpo mítico suposto estar em todos os lugares, tudo encontrar, tudo ver.

Gallo e Romão (2011, p. 13) se debruçando em estudos sobre o corpo e a rede eletrônica, conceituam o corpo na Análise do Discurso “[...] como opaco e permanentemente incompleto, [...] atravessado pelas ilusões constitutivas do dizer e pelas formações imaginárias". $\mathrm{Na}$ especificidade da pós-modernidade, assinalam que as incidências de discursos sobre o tempo e o espaço da rede eletrônica no corpo, fazendo falar um gerúndio supostamente interminável, "[...] que coloca o corpo em estado de alerta, colado à máquina tomando-a como uma extensão de si [...]" (p. 14), constituem sentidos sobre um corpo que não pode parar de digitar, de navegar, de acessar, de comunicar. Esses sentidos localizamos em nossa terceira questão apresentada na introdução, e são sentidos que conversam sobre o impossível do corpo que paira também na corpografia pela via do comparecimento do corpo onde ele não pode fisicamente. Gallo e Romão (2011) localizam nesses discursos e sentidos, efeitos de naturalização de um corpo sem limites - sendo mau visto o descanso, a lentidão - efeitos que incitam que o corpo se cole à tela da tecnologia, e se torne peça da tecnologia, extensão da máquina potente, e a máquina, por sua via, objeto de corpo. Conforme as autoras,

[...] o corpo aparenta estar distendido em supostas potências, como por exemplo, ser cada vez mais rápido, digitar com mais destreza, conversar com mais gente, acelerar as respostas, responder a mais e-mails, dizer telegraficamente de modo compactado, estar em vários lugares, deixar-se ver por vários, implicar-se na exibição pública de suas questões privadas. Passa a contar por sua (oni)presença [...]. Dizer de seu corpo e com ele de modo a 
fazê-lo parecer uma máquina tão eficaz quanto o próprio computador: eis uma das ilusões da contemporaneidade que julgamos ser necessário desnaturalizar. (Gallo \& Romão, 2011, p. 15-16).

No avesso dessas ilusões, as autoras apontam que o efeito de presença absoluta é furado pelo impossível do/no corpo, pois o sono pesa e é preciso se desligar, ainda que a tela permaneça acesa (enquanto houver energia e o sistema não entrar em obsolescência). E alertam que "[...] estamos diante da espessura do impossível-navegar no corpo, questão que precisa ser tocada, até porque, diante da suposta potência da tecnologia e da eficácia de máquinas de comunicar e conectar, a fragilidade e o impossível do corpo comparecem como limite [...]” (Gallo \& Romão, 2011, p. 16). Limite que muitas vezes é discursivizado como déficit, imputado ao corpo considerado não acompanhar os avanços da tecnologia, e não como uma questão constitutiva do corpo e do sujeito. Apontamos a importância da discussão dessas questões que incidem no corpo e que tentam tamponar o real do corpo e pontuamos que a fixação na questão do ilimitado sustentado pelos discursos legitimados sobre a rede eletrônica e sobre os objetos tecnológicos de conexão à rede eletrônica, alocam o corpo na ordem de uma supra-potência, quando conectado, que não é dele constitutiva.

Conforme Gallo e Romão (2011, p. 19), “[...] todo sujeito, negando suas contradições, parece transportar-se, como o Barão, puxando-se pelos seus próprios cabelos, num gesto autônomo [...]". Não é a representação do Barão que podemos ver discursar no corpo acoplado a tela do objeto tecnológico de conexão à rede eletrônica, na Figura 19? Um sujeito que se supõe autônomo, que não é abalado pelo choque com a memória, com o corpo que o antecede na linha evolutiva, com aquilo que o antecede e o constitui. Um sujeito que colado a tela do objeto tecnológico, coloca uma das mãos no bolso, a outra na tela, curva os olhos para baixo e finca os pés em uma posição-sujeito que se supõe não fragilizada pelo real do corpo? Um real escamoteado posto que supostamente tudo se encontra na rede eletrônica, inclusive um corpo potente no virtual que permite que o corpo físico fique bem imóvel. Um corpo que, como apontou Robin (2000) faz pouco do real?

Azevedo (2013b) trabalha com o conceito de "tecnologias corporais" se pautando no conceito de "técnicas corporais" de Mauss (1974). Para o antropólogo, as técnicas corporais são os modos como os homens se servem de seus corpos a partir de práticas sociais, culturais e históricas. Práticas coletivas e individuais que variam de sociedade para sociedade e que consistem na adaptação do corpo, na educação do corpo. Como já dissemos, para Mauss (1974), o corpo é o primeiro instrumento do homem, e, sendo conotado como instrumento, ele já é perpassado pela cultura. Conforme Azevedo (2013b), a teoria de Mauss permite “[...] pensar o 
aspecto político investido em tais técnicas, pelo viés da história e da cultura" (p. 84) e, com a Figura 19, podemos visualizar o referido conceito atravessando cada corpo, na medida em que práticas sociais, culturais e históricas incidem na constituição corpórea. Os corpos vão se transformando com os passos e vão tomando outros instrumentos em mãos, ao mesmo tempo em que se afastam do corpo do animal, pela própria criação da cultura, ou seja, da língua e dos objetos.

Segundo Azevedo (2013b), a partir da concepção de Mauss, é possível pensar, na pósmodernidade, nas técnicas corporais levando-se em consideração a complexidade das questões que permeiam o corpo em uma sociedade de mercado tecnologizada. Ancorada nessa concepção, a autora investe num deslizamento da técnica para a tecnologia, formulando o conceito de tecnologias corporais, o qual aborda as especificidades e as sobredeterminações do corpo pela tecnologia, ou seja, os sentidos que são produzidos para e sobre o corpo a partir das tecnologias. Para a autora, “[...] Há uma naturalização de certas práticas corporais contemporâneas, práticas atreladas à tecnologia midiática e eletrônica, ou seja, à publicização e espetacularização da corporalidade, bem como à quantidade estruturante dessas relações de sentido" (Azevedo, 2013a, p. 84), algo que Debord (2003) tem apontado desde a década de 60.

A autora propõe "[...] chamar tecnologias corporais, modos de inscrever sentidos sobre/dos corpos fortemente constituídos pelas tecnologias, ou mais precisamente, à contradição latente presente na tecnologização do corpo do sujeito [...] (Azevedo, 2013a, p. 23). Assinala que toma as tecnologias corporais não apenas como extensões do corpo humano, mas também relacionadas ao político, à produção de sentidos, à ideologia, ao inconsciente. São práticas "[...] que se inscrevem em determinada formação discursiva e colocam como fundamental a relação com a falta e com o excesso [...]" (Azevedo, 2013b, p. 98). Nas análises que empreende, chega à conclusão que "[...] tanto as próteses anexadas ao corpo quanto a medicalização - como prótese de sentido - são formas desse movimento, no qual há a produção de efeitos de sentido de perfeição ancorado em uma intensificação do potencial do corpo humano através da tecnologia [...]” (p. 96).

Afirma que a tecnologia é inscrita na formulação e circulação de sentidos que sustentam “[...] uma nova antropomorfia do corpo humano [...]" (p. 100), associada à crescente intervenção da tecnologia no corpo, seja como prótese, seja como implante. Sentidos que se ligam a um corpo híbrido, misto de orgânico e máquina e se filia a sentidos sobre o ciborgue. Segundo Azevedo (2013b), as próteses são consideradas uma parte ciber do corpo que suplanta alguma fragilidade do orgânico aumentando seu poder, sendo assim, aponta que a cibernética 
marca a possibilidade de se significar a vida pensando o corpo cibernético a partir da teoria da comunicação, como se tudo fosse uma questão de hardware.

Essa é uma discursividade que significa o corpo humano através do funcionamento da metonímia: a parte pelo todo. É a máquina que sobredetermina o sentido do corpo, em detrimento do orgânico que é silenciado. A consequência é a negação ou apagamento da fragilidade humana e a potencialização do corpo para além do biológico. Assim, longe da encarnação de um futuro aberto à ambiguidade e à diferença, o corpo significado pela máquina silencia a imperfeição, reduz a falha a um erro de cálculo e a corporalidade à matéria numérica. É o silício que se projeta sobre o corpo, silenciando a precariedade da carne como condição de nossa humanidade (p. 102).

A partir dessa citação, articulamos a metonímia materializada na Figura 19, que marca partes do corpo movendo o corpo todo, como podemos destacar: os dedos no objeto tecnológico e os olhos. Partes do corpo que garantem a conexão e a imobilidade do restante do corpo. Retomamos mais uma vez a questão do apagamento da fragilidade humana e a potencialização do corpo acoplado ao objeto tecnológico, discurso que atravessa e constitui uma posiçãosujeito, um corpo a que nos referimos no contexto da pós-modernidade, que não se abala e marca uma ruptura com o corpo de outrora, acreditando-se sem exterioridade. Azevedo (2013b) diz que "[...] as tecnologias corporais integram dispositivos de gestão-controle administrativos que, conforme Pêcheux (2011), constituem um espaço de tomada de posição política, ideológica e teórica [...]”' (p. 104). Esses dispositivos de gestão-controle acabam por fazer circular sentidos que negam a fragilidade do corpo, e, negando, tentam criar um corpo sem exterioridade, como se a ideologia não mediasse a relação de sujeitos e máquinas. Para a autora, a tecnologia estabiliza os referenciais imaginários que constituem sentidos para o corpo, e, abordar as tecnologias corporais possibilita compreender a historicidade do corpo, a forma como as práticas corporais se formulam a partir de técnicas cristalizando saberes sobre o corpo.

Apresentamos, assim, algumas tessituras sobre o conceito de corpo, que deixam bem marcados os passos deixados por Pêcheux no arcabouço discursivo. O corpo, desse modo, é constituído por discurso, e, como todo processo discursivo, tem a língua como base, é afetado pela ideologia e pelo recalque inconsciente. Portanto, é permeado pela exterioridade que o retira do âmbito da carne. Apresentamos alguns gestos de interpretação que nos auxiliam a compreender o processo de produção de sentidos sobre o corpo na pós-modernidade e, na próxima seção, abordaremos o que nomeamos por posição-sujeito corpo (inter)face, formulado a partir de todo o referencial teórico e analítico que norteia a presente pesquisa. Tentaremos responder, por meio dele, as questões que nos propusemos e que implicam em estudar o 
processo de constituição de sentidos sobre o corpo a partir dos discursos sobre os objetos tecnológicos de conexão à rede eletrônica.

\subsection{A posição-sujeito corpo (inter)face}

A partir do ancoramento teórico e analítico que delineamos nos três primeiros capítulos, apresentaremos uma tomada de posição do sujeito, que depreendemos do nosso gesto de interpretação às materialidades discursivas que encontramos ao longo desses anos de pesquisa na rede eletrônica, a fim de compreendermos o processo de produção de sentidos sobre o corpo: silenciado, potente e sem limites na relação com o objeto. Trata-se da posição-sujeito corpo (inter)face. Contudo, num primeiro momento, faremos uma retomada dos processos de imposição/dissimulação, interpelação/identificação, assujeitamento/subordinação do sujeito até a formalização do que chamamos de corpo (inter)face e sua marca como posição discursiva.

O sujeito se constitui como tal nos processos de imposição/dissimulação e interpelação/identificação, nos quais ao mesmo tempo em que é assujeitado pela interpelação da ideologia, pelo recalque do inconsciente e se identifica ao Sujeito/Outro, é tomado pelo efeitos dos esquecimentos, os quais operam em um faz de conta de autonomia, configurando o que Pêcheux (2009a) chamou de "teatro da consciência", ou melhor, a evidência do sujeito como idêntico a si mesmo, ocultando o estranho-familiar de sua divisão. Como apontam Schons e Mittmann (2009, p. 301), “como não há sujeito sem assujeitamento, todo sujeito age e toma posição sob os efeitos La Palice (da evidência de si) e Münchhausen (da auto-suficiência) [...]”".

Conforme o fundador da Análise do Discurso, tais processos de assujeitamentosubordinação, que se realizam sob a forma de autonomia, produzem o sujeito do discurso no enlaçamento à forma-sujeito, pela identificação com a formação discursiva dominante, que por sua vez é atravessada por formações ideológicas. No processo de produção do sujeito, então, trabalham o assujeitamento e a impressão de autonomia, a qual funda sua unidade imaginária. De acordo com Schons e Mittmann (2009, p. 3030), “[...] o sujeito só tem acesso à parte do que diz, ele é estruturalmente dividido, desde sua constituição [...]. Não é uma forma de subjetividade, mas um "lugar" que ocupa para ser sujeito do que diz [...]". Lugar afetado pelo modo com que cada sujeito se relaciona com a linguagem e que produz o seu lugar no interior do complexo das formações ideológicas, o interdiscurso. 
Lembremos que Pêcheux (2009a) elenca três modalidades da forma-sujeito, discutindo a relação do sujeito da enunciação com o Sujeito universal (materializado na formação discursiva dominante), ilustrando tomadas de posição do sujeito no assujeitamento sustentadas na identificação com a formação discursiva dominante, na contra-identificação e na desidenticação. Conforme vimos com Payer (2005), nas atuais condições de produção dos discursos, o Mercado é o grande Sujeito que nos interpela ideologicamente, e como produto dessa interpelação advém uma forma de sujeito. Apoiando-nos em seus apontamentos e os articulando ao que temos escutado em nossos gestos de interpretação às materialidades discursivas encontradas, podemos dizer, então, que, no processo de identificação do sujeito com o Sujeito/Mercado, o sujeito ao se identificar com a formação discursiva dominante, a qual nomeamos por formação discursiva do mercado, enlaça-se, por sua vez, à forma-sujeito que nomeamos como do mercado. Forma-sujeito que responde aos enunciados do Mercado de modo que o sujeito ocupe um lugar de ideal, na injunção ao sucesso e à visibilidade (sendo visto e tudo vendo), na medida em que o corpo comparece como interface do objeto tecnológico de conexão à rede eletrônica, sendo discursivizado no campo da fusão com o objeto.

Prosseguimos sublinhando, portanto, que à forma-sujeito do discurso se liga uma tomada de posição do sujeito, ou ainda, uma posição do sujeito no discurso. Segundo o Glossário de Termos do Discurso (2001, p. 18), a posição-sujeito

[...] é resultado da relação que se estabelece entre o sujeito do discurso e a forma-sujeito de uma dada formação discursiva. Uma posição-sujeito não é uma realidade física, porém um objeto imaginário, representando no processo discursivo os lugares ocupados pelos sujeitos na estrutura de uma formação social. Desse modo, não há um sujeito único, mas diversas posições-sujeito, as quais estão relacionadas com determinadas formações discursivas e ideológicas.

Embora haja diversas posições-sujeito, trabalharemos, nessa pesquisa, os efeitos de uma posição-sujeito, a qual denominamos corpo (inter)face, e que responde às questões que formulamos, indiciando os processos de constituição de sentidos sobre o corpo a partir dos discursos sobre objetos tecnológicos, assim como sobre a relação sujeito, corpo e objetos tecnológicos de conexão à rede eletrônica. Como abordamos no capítulo 2, a referida relação tem se dado no âmbito de um acoplamento do corpo com o objeto, donde o corpo se torna interface direta do objeto tecnológico, ou ainda, partes do corpo, como a face e o olho, se tornam interface na interação, especialmente no caso dos objetos tecnológicos óculos e lentes de 
contato, ilustrados no referido capítulo. Tal acoplamento é revestido de discursos associados a potência.

Apresentaremos a composição dessa posição-sujeito, a qual dividimos em: 1) o "corpo interface", ou seja, o corpo como interface, reverberando sentidos sobre o ciborgue, mas ressoando sentidos sobre o corpo faltante. 2) o "corpo face" referindo-se de um lado à face, rosto, já que tanto a face quanto o órgão olho são visados no acoplamento com os objetos tecnológicos de conexão à rede eletrônica óculos e lente de contato - objetos com os quais trabalhamos com algumas sequências discursivas no capítulo 5; assim como se referindo a face(book), rede social que metaforiza a rede eletrônica, na qual o corpo comparece como face, como um livro de rosto, mas representando o corpo todo, um corpo ideal na rede. Assim, Facebook comparece como metáfora da rede eletrônica e, o perfil no Facebook, metonímia do corpo, uma parte pelo todo. 3) o "corpo inter face", no qual o "inter" ao mesmo tempo em que se refere a internet modalizando os sentidos sobre corpo e as partes dele, também faz comparecer o "entre", um intervalo que, pela via da falta, desvincula esse conceito do conceito de ciborgue, o qual se restringe a afirmação da fusão corpo-máquina.

Delinearemos, a seguir, cada uma dessas facetas da posição-sujeito corpo (inter)face, a qual, embora mapeada nesse gesto de interpretação que a constitui, compõe-se de forma plural nas análises tecidas no próximo capítulo, posto que não é uma noção a ser engessada, mas sim uma noção que oferte possibilidades de gestos de interpretação sobre a relação sujeito, corpo e objetos tecnológicos de conexão à rede eletrônica, para além dos sentidos sobre ciborgue.

Retomemos que interface é o termo utilizado para nomear os aparatos que possibilitam direta ou indiretamente a interação entre o corpo e o objeto tecnológico de conexão à rede eletrônica (Lévy, 2005), e que esses aparatos abrangem, por exemplo, mouse, teclado, tela, sensores, e inclusive o corpo pode comparecer como interface. Como vimos, com a miniaturização dos objetos tecnológicos - sustentada pelo poder do Mercado (Payer, 2005) aliada à produção da ciência que neles têm investido para que se tornem cada vez mais portáteis, vestíveis - estes foram se destituindo de interfaces como as citadas anteriormente, interfaces que antes intermediavam a relação corpo e objeto tecnológico, e que, agora, apresentam a possibilidade de uma interação cada vez mais próxima entre o corpo e o objeto tecnológico de conexão à rede eletrônica, na qual há o acionamento direto das interfaces operacionais. No caso dos óculos que conectam a rede eletrônica, a voz, o toque e o olho são conclamados nos comandos. No caso da lente de contato que conecta a rede eletrônica há uma tendência da relação com a interface operacional se dar somente por comandos dos olhos, sendo discursivizado que são desnecessárias outras partes do corpo para a conexão. 
Assim, quanto mais o objeto tecnológico se acopla ao corpo - e cada vez mais se acopla a órgãos, como os olhos - cada vez menos se precisa de outras interfaces que não o corpo ou, mais precisamente, de outras partes dele para a conexão. Vimos que os discursos sobre o ciborgue contemplam a modalidade de relação fusional entre o corpo e os objetos tecnológicos, funcionando nessa modalidade discursiva a junção corpo-máquina a ponto de uma indiferenciação, nascendo discussões sobre onde começa o corpo, onde começa a máquina, quais são as fronteiras. Discussões que permeiam os discursos na posição-sujeito corpo (inter)face, mas que não se esgotam nesses sentidos, posto que fossem só esses os sentidos em cena, poderíamos utilizar o termo posição-sujeito ciborgue. Apoiamo-nos então, na concepção de Pêcheux (2009a) de que, se por um lado a língua tem a capacidade de construir o unívoco pelos efeitos dos esquecimentos, por outro lado, a desestabilização é constitutiva da língua, do discurso e do sujeito. Assim, se os efeitos do ciborgue comparecem nas discursividades que analisamos, não deixaremos de apontar o que esses sentidos silenciam: o corpo delineado pela Análise do Discurso, pela Psicanálise, um corpo pulsional, sujeito à linguagem, sujeito a historicidade. Pois, concebemos que, ao se discursar sobre o ciborgue, se diz de algum modo de um não corpo, e, pela via da negativa, sabemos bem que os sentidos retornam ao discurso, como já dizia Freud (1925/1996b).

Nessa tomada de posição, que implica o nosso gesto de interpretação, apontamos que na posição-sujeito corpo (inter)face, a questão não se esgota na discussão sobre as fronteiras ou as não fronteiras dessa relação, pois, como vimos com Freud (1930/2010) são questões que permeiam as fronteiras do (enamoramento) imaginário, que funcionam na ordem da junção ou da disjunção com o objeto. Na posição corpo (inter)face, sentidos outros podem transpirar, como o sentido apontado por Lacan (2003a, 2003d) na metáfora que afirma que "não há relação sexual", ou seja, há o impossível que atravessa o corpo e também o objeto na imaginária junção. Assim como também o simbólico que dá contorno ao corpo.

A posição-sujeito corpo (inter)face enuncia o silenciamento do corpo faltante, corpo bem delineado pela Análise do Discurso e pela Psicanálise, lembrando que, conforme Orlandi (2007a), o silenciamento é colocar sentidos em silêncio. Afinal, na lógica do Mercado, na injunção ao sucesso e a visibilidade, cabe a legitimação de sentidos de fusão corpo-máquina, a busca pela potência, e sobretudo, pelo consumo de um objeto que supostamente suplantaria a falta. Expondo esse silenciamento, marcamos o "corpo" na nomeação "posição-sujeito corpo (inter)face" e ressaltamos que ele é palavra obliterada na nomeação "ciborgue", posto que, nesse modo de conceber corpo, ele se torna outra coisa que não se sabe bem se é máquina, se é corpo-máquina, prevalecendo sempre os sentidos maquínicos. Na posição-sujeito com a qual 
tecemos gestos de interpretação, embora sentidos sejam legitimados como os citados sentidos sobre o ciborgue, os sentidos sobre o corpo não são inexistentes, eles reverberam nos poros das palavras. Como no retorno do recalcado (Freud, 1915/1996g), os sentidos de um corpo faltante pulsam, ainda que em um aparente hermetismo.

Desse modo, poderemos avistar na posição-sujeito corpo (inter)face: 1) O impossível do corpo, conforme vimos com Gallo e Romão (2011). 2) O corpo que intenta se materializar na rede eletrônica, no caso de nossas análises, não exatamente como corpográfico como salientou Dias (2008), mas o corpo que tenta se inscrever de algum modo no eletrônico, no virtual, assim como o objeto tecnológico também se inscrevendo no corpo. 3) O corpo atravessado pelas sobredeterminações das tecnologias corporais, como salientou Azevedo (2013a, 2013b). 4) O corpo como produção da interpelação ideológica e do recalque do inconsciente, como delineado por Orlandi (2012a, 2012b, 2014). 5) O corpo pulsional, afetado pelos efeitos da causa de desejo e do gozo, como propõe a psicanálise segundo Freud e Lacan. Se o corpo comparece como interface nos investimentos do Mercado e da ciência, e interface que substitui as interfaces maquínicas, apontamos que, na posição-sujeito corpo (inter)face, comparece a faceta ciborgue, na qual o sujeito é capturado pelo imaginnário do "Eu sou" (Pêcheux, 2009a), quiçá ciborgue, e ressoa a faceta do corpo faltante, que movida pela busca do desejo, se enrosca nos objetos tecnológicos que fazem semblante de objeto $a$, de modo caricatural. Enfatizamos que essa leitura intenta abrir os sentidos sobre a relação corpo e objetos, para além da potência e impotência anunciada midiaticamente e que captura os sujeitos e seus corpos. Na leitura que tecemos sobre a posição-sujeito corpo (inter)face não desconsideramos os sentidos apontados por Lemos (2010b) de que somos, no mínimo, ciborgues interpretativos pela influência dos mass media. Porém, apontamos que essa é apenas uma faceta do discurso sobre o corpo, aquela que caracteriza o "Eu sou", bem delineado por Pêcheux (2009a).

Apontando o acoplamento corpo e objeto tecnológico de conexão à rede eletrônica, no âmbito do corpo como interface, o "corpo face" que pontuamos é processo discursivo que se configura na medida em que a face e, sobretudo, os olhos são elencados como interfaces privilegiadas. Nessa relação entre objeto tecnológico e face/olhos, é produzido discursivametne um corpo que, inerte - ao movimentar apenas os olhos, comandos estereotipados de voz ou ainda toques -, se movimenta plenamente na rede eletrônica, no virtual, tudo podendo fazer, encontrar, dizer. Um corpo que se configura como órgão/olho de um lado, e, de outro, total, pleno no virtual. Esses sentidos materializados nas formações discursivas do Mercado e na forma-sujeito do mercado que os veiculam apontando um corpo potente ao passo que é movente 
na rede e inerte na "realidade", encontram eco no sujeito, criando demandas de um gozo com o objeto. Como vimos no campo da Psicanálise, o eu e o corpo se constituem a partir de uma imagem que se crê plena, mas que reverbera em toda a vida do sujeito em oscilações entre despedaçamento do corpo e imagem total, dois posicionamentos opostos, que comparecem nos enunciados do Mercado (Payer, 2005) em relação a oferta de objetos tecnológicso de conexão à rede eletrônica, e que provocam no sujeito a busca por tentar encontrar a completude com o objeto e a tamponar/não lidar com o impossível do corpo.

No campo da imagem, também podemos dizer de um "corpo face" que, atrelado aos sentidos sobre o Facebook, a rede social que mais reúne internautas, reitera tais sentidos sobre a parte representando o todo, um perfil representando o sujeito, o corpo do sujeito, capturado em sentidos de um ideal. Sublinhamos que outros sentidos emergem sobre o Facebook, estamos elencando nas análises aqueles que reverberam nas materialidades encontradas.

Na posição-sujeito corpo (inter)face comparecem, então, sentidos que legitimam a parte do corpo como representativa do corpo todo, no virtual e na "realidade", como se só o órgão que propicia a conexão fosse necessário ao sujeito-corpo, posto que a rede eletrônica é o espaço legitimado para o viver, em discursos na pós-modernidade. Como já dissemos, ao focar os olhos, os enunciados do Mercado sustentam a primazia da visibilidade já sustentada pela mídia há algumas décadas, haja vista os apontamentos de Debord (2003). Um campo de visibilidade que se ampara no tudo ver, agora com a oferta da realidade aumentada, velando um outro campo, o do olhar, como objeto da pulsão escópica que aponta os furos do objeto olho e do olhar, como vimos com Lacan (1998e).

Portanto o "inter" da posição-sujeito, além de apontar que os sentidos sobre corpo e face são advindos dos sentidos sobre “inter"net, rede eletrônica, objetos tecnológicos de conexão à rede eletrônica, - e, de modo mais incisivo, com as tecnologias vestíveis, destacamos, principalmente o sentido de "intervalo", do "entre", que nos rememora o sujeito entre significantes (Lacan, 1998c), que, na cadeia discursiva, pode advir num respiro, por entre os poros das palavras, escapando do silenciamento, e tecendo outros sentidos para o corpo, para além da potência, da impotência, sentidos e, sobretudo, não sentidos sobre o impossível. Assim, o corpo aqui evocado traz a marca da divisão, é corpo barrado, e silenciado nos discursos que interpretamos, comparecendo envolto em sentidos que se restringem ao acoplamento, que se restringem ao modo de utilizar o objeto tecnológico. Se no ciborgue está posta a busca da potência, da completude, o corpo (inter)face, embora também seja banhado por esses sentidos, porta o corpo como barrado, porta o real do corpo, o impossível, e é afetado pelo objeto $a$, causa de desejo, e não só pela busca de um objeto que tome a forma do que supostamente completaria. 
Se na posição-sujeito corpo (inter)face comparece um lugar no qual o sujeito se enlaça à formação discursiva do mercado e a forma-sujeito do mercado, respondendo com um corpo consumidor, também consumido, movente na rede, há que se dizer dos sentidos silenciados por um forçamento na barra que os recalca. Como Payer (2005) apontou, o poder do Mercado incide de modo a não deixar espaço para nenhum outro discurso, para nenhuma outra forma de sujeito, para nenhum outro tipo de corpo a dar suporte ao objeto tecnológico, como se não houvesse exterior ao Mercado. Como afirmou Braunstein (2010), no discurso do mercado há uma ideologia da foraclusão do sujeito, aquele que se acredita autônomo quando maneja o objeto tecnológico não se dando conta de seu assujeitamento, que sutenta a máquina do mercado e do consumo, ao se enlaçar na ilusão de que o objeto tecnológico completará sua falha a ser.

No próximo capítulo, apresentaremos as especificidades do método da Análise do Discurso, que se diferencia consideravelmente de outros métodos, inclusive de outras ciências da linguagem, e também apresentaremos a metodologia da presente pesquisa, construída na opacidade do movimento de ir e vir entre teoria e análise. É, portanto, momento de formalização metodológica. 


\section{O MÉTODO E(M) DISCURSO}

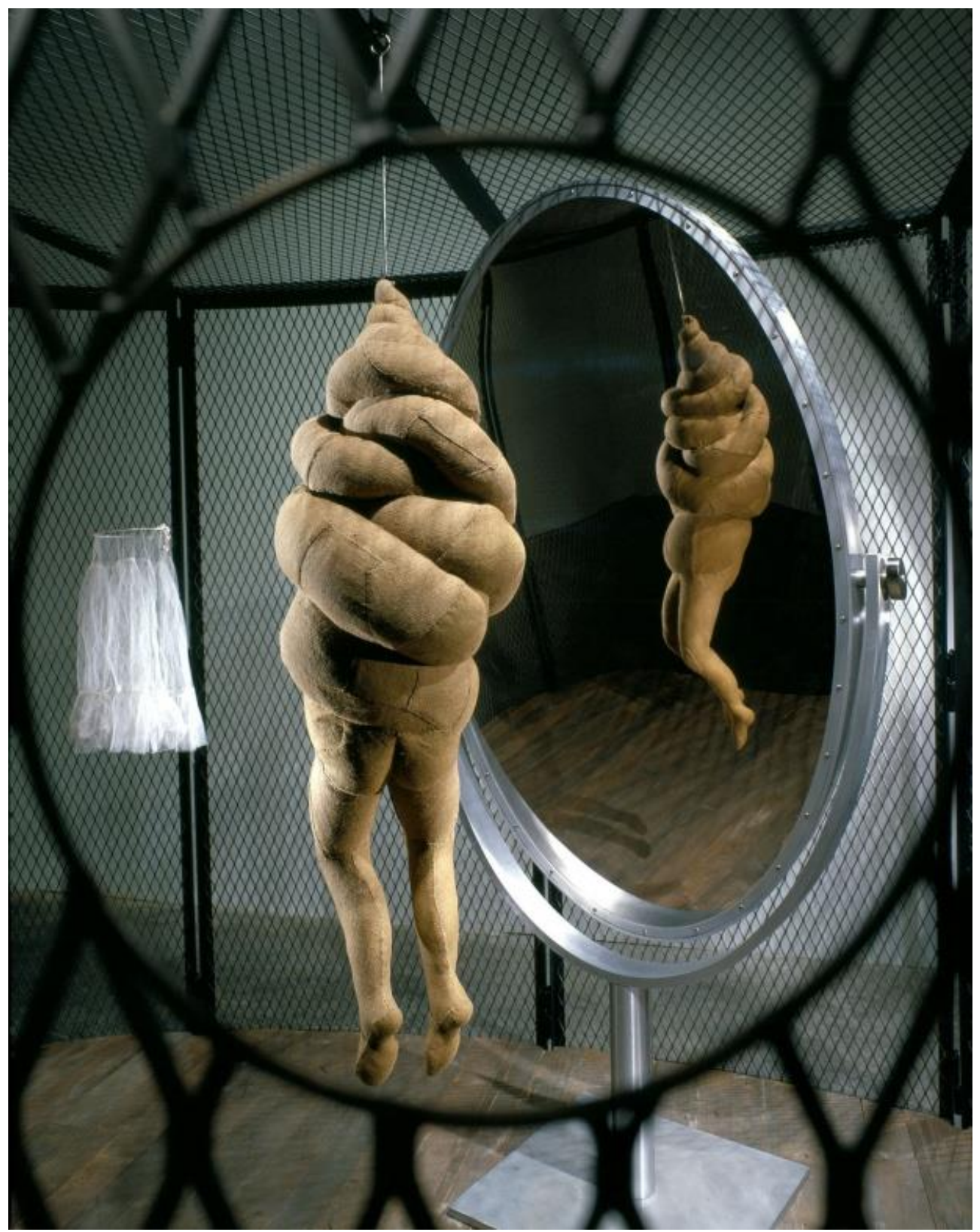

Cell XXVI (Louise Bourgeois, 2003)

Palavras

[...] lanço a primeira palavra, a segunda e a terceira, como pássaros a que foi aberta a porta da gaiola, sem saber muito bem, ou não sabendo de todo, aonde eles me levarão. Falar torna-se então uma aventura, comunicar converte-se na busca metódica de um caminho que leve a quem estiver escutando, tendo sempre presente que nenhuma comunicação é definitiva e instantânea, que muitas vezes é preciso voltar a trás para aclarar o que só sumamente foi enunciado. 
Como temos dito, há processos de produção de discursos e sentidos. Sendo a presente pesquisa um discurso, temos a dizer que há um processo de constituição, de formulação e, por fim, de produção, da pesquisa, assim como há processos de produção metodológica no campo da Análise do Discurso que a diferencia de outros campos. Abordaremos, portanto, o método dessa disciplina de interpretação e o processo de produção da pesquisa "Corpo (inter)face: sentidos sobre a relação sujeito, corpo e objetos tecnológicos de conexão à rede eletrônica".

O método em Análise do Discurso é fundamentado pela singularidade da teoria e das técnicas de análise delineados por essa disciplina, que trabalha com a língua, o sujeito e o discurso, em uma perspectiva que é estruturada pela falta. Posicionando-se no campo das ciências da linguagem, o método em Análise do Discurso tem características próprias que o diferencia do método dessas ciências, dos métodos quantitativos, qualitativos e ainda quantitativos-qualitativos.

Diferencia-se do método quantitativo, por não visar a uma exaustividade numérica, horizontal, em extensão, pautado no controle do objeto, posto que "[...] ele é inesgotável. [...]" (Orlandi, 2010, p. 62). Ao contrário, a exaustividade almejada é a vertical, ou seja, a "exaustividade em profundidade" (Orlandi, 2010, p. 63) dos fatos discursivos, mas que considera a impossibilidade de se abordar o todo pela própria incompletude da língua e do sujeito.

Diferencia-se do método qualitativo tradicional, sobretudo, por não visar a uma análise conteudista dos fatos discursivos, ênfase que Pêcheux aponta em toda sua obra nas discussões sobre as ciências humanas. Diferencia-se do domínio da linguística ao constituir "[...] um objeto-linguagem diferente daquele instaurado pela linguística tradicional, porque procura tratar dos processos de constituição do fenômeno linguístico e não meramente do seu produto. Esse é o recorte teórico inicial (básico) para a análise de discurso" (Orlandi, 2012b, p. 20).

Em "Discurso: estrutura ou acontecimento", Pêcheux (2008) faz importantes apontamentos sobre a diferenciação dos gestos de interpretação e descrição na Análise do Discurso em relação aos outros campos do saber e faz isso acompanhando discursividades sobre o que chama de "o fato novo", como por exemplo, a vitória de Mitterand na França, para discutir o acontecimento discursivo produzido no enunciado "On a gagnê". Aponta também que o mesmo fato, a vitória de Mitterand, não construiu as mesmas significações nas formulações que circularam na época, fato que sustenta a questão do efeito de sentido entre interlocutores, e que “[...] uma mesma palavra, uma mesma expressão e uma mesma proposição podem receber sentidos diferentes [...]" (Pêcheux, 2009a, p. 147), de acordo com aqueles que a empregam. 
Pêcheux (2008, p. 31) aponta, sobretudo, para o "[...] estatuto das discursividades que trabalham um acontecimento, entrecruzando proposições de aparência logicamente estável [...]", em que figuram interrogações disjuntivas, do tipo isso é A ou isso é não A, e que fecham a questão da interpretação do fato novo. Discute a questão da interpretação, e também os gestos de descrição, dizendo que as categorizações desconsideram "[...] por exemplo, o enunciado: "Fulano é muito 'militar' no civil”, enunciado que é, aliás, perfeitamente dotado de sentido". O fundador da Análise do Discurso assinala que o espaço administrativo (jurídico, econômico e político) tenta controlar os pontos de impossível, criando "técnicas" de gestão social dos indivíduos, seja com o objetivo de identificá-los, compará-los, colocá-los em colunas, tabelas, separá-los em grupos, amparados pela lógica disjuntiva na qual se considera '[...] 'impossível' que tal pessoa seja solteira $e$ casada, que tenha diploma $e$ que não o tenha, que esteja trabalhando $e$ que esteja desempregado, [...] que seja civil $e$ que seja militar, que tenha sido eleito para tal função $e$ que não o tenha sido, etc...” (p. 30). Assim, afirma que nessa cobertura lógica em que prevalece uma suposta totalidade, uma homogeneidade nas proposições, tudo funciona como se ninguém pudesse escapar desse funcionamento.

Conforme Pêcheux (2008), o domínio das ciências exatas e das tecnologias também se amparam no logicamente representável, e, ademais, ressalta que o sujeito pragmático, cada um de nós, apresenta uma considerável necessidade de homogeneidade lógica em seu cotidiano, como por exemplo, usar de um porta-notas para não esquecer, os documentos para se identificar, as agendas para anotar e programar atividades, as chaves para abrir e fechar. $\mathrm{O}$ pensador francês enfatiza que nos espaços discursivos "logicamente estabilizados" supõe-se que todo sujeito sabe do que fala, e aqui podemos retomar o esquecimento número 1 e número 2, que causam a impressão de autonomia e consciência do sujeito.

Destaca, sobretudo, que não adianta negarmos a necessidade de um "mundo semanticamente normatizado", o que ele assinala começar "[...] com a relação de cada um com seu próprio corpo e seus arredores imediatos (e antes de tudo com a distribuição de bons e maus objetos, arcaicamente figurados pela disjunção entre alimento e excremento)" (Pêcheux, 2008, p. 34). Para ele, uma estrutura representável e homogênea, responde a uma urgência humana e não deixa de se materializar por todos os meios, deixando a questão: "A promessa de uma ciência régia conceptualmente tão rigorosa quanto as matemáticas, concretamente tão eficaz quanto as tecnologias materiais, e tão onipresente quanto a filosofia e a política!... como a humanidade poderia ter resistido a semelhante pechincha?" (p. 35). Em "Nota sobre a questão da linguagem e do simbólico em psicologia”, Pêcheux, Gadet, Haroche e Henry (2011b, p. 56) escrevem, nesse sentido: 
As ciências, as tecnologias e as administrações se inscrevem em um espaço linguajeiro bem específico que funciona apoiando-se sobre uma das propriedades fundamentais da linguagem: sua capacidade de construir o unívoco. Se as línguas naturais não tivessem nelas mesmas nenhuma estabilidade morfológica e sintática, a própria visão da univocidade seria impensável. Mas não se pode ignorar que, fora dos domínios evocados, esse tipo de estabilidade (a língua como corpo de regras) autoriza ao mesmo tempo uma contínua 'desestabilização' da univocidade: contrariamente às línguas lógicas artificiais, a linguagem é irredutível a uma ordem homogênea [...].

Assim, Pêcheux (2009a) delineia que se a língua tem a capacidade de construir o unívoco, sujeito e o discurso também têm essa capacidade na medida em que os esquecimentos $n^{\circ} 1$ e $n^{\circ} 2$ trabalham juntamente com a interpelação ideológica e o recalque inconsciente nos processos de imposição/dissimulação, porém, assinala também, e sobretudo, que a desestabilização é constitutiva da língua, do discurso e do sujeito. Segundo o fundador, colocar em causa as evidências significou abrir uma falha no campo das tecnologias, das psicologias do ego, do comportamento, restituindo o lugar da castração simbólica, fato estruturante da humanidade.

A partir desse percurso, podemos dizer, então, que a diferença fundamental entre o método da Análise do Discurso e de outros campos do saber está na maneira como o analista de discurso desloca a noção de "dado" para a noção de "fato", deslocamento que "[...] colocanos no campo do acontecimento linguístico e do funcionamento discursivo" (Orlandi, 1996, p. 209), já que há um trabalho com o "dado" (produto), há um gesto teórico no trabalho com o dado, que aponta para o "fato" (processo de produção dos sentidos). Acrescentamos, portanto, que não se trata de separar o dado do fato, posto que a Análise do Discurso não trabalha com essa ilusão. Trata-se de um deslizamento de um para o outro, a partir do gesto de interpretação, porque o ato de relacionar um dado com com sua exterioridade, já o faz deixar de ser "dado", pronto, acabado. É o que Pêcheux (2008) fez em seu gesto de interpretação ao "On a gagné", às formulações noticiadas sobre a vitória de Mitterand e às ciências em geral. A Análise do Discurso não trabalha com as evidências, mas com o processo de produção das evidências, sendo a noção de dado um efeito ideológico. (Orlandi, 1996).

A partir das diferenças pontuadas, concluímos que a epistemologia à qual se alinha a Análise do Discurso não é a positivista, mas sim a epistemologia histórica que considera a descontinuidade e suprime a separação entre " [...] objeto/sujeito, exterioridade/interioridade, concreto/abstrato, origem/filiação, evolução/produção etc. [...]” (Orlandi, 1996, p. 209). Conforme enuncia Maldidier (2010), desde a maquinaria discursiva Pêcheux estabelecia a 
teoria de um objeto novo, a partir da relação discurso e corpus, já que esta era irredutível ao enunciado longo (típico do trabalho dos linguistas), e o discurso era desde já construído a partir de hipóteses históricas, não se confundindo com a evidência dos dados empíricos, e o corpus já estabelecia uma relação com o exterior, um não fechamento em si mesmo.

Quanto ao "método", apoiada em Saussure (1962), Orlandi (2012b, p. 18) define que este determina o objeto. Citando também Paul Veyne (1971), a autora afirma ainda que um objeto visto de diversas perspectivas não é o mesmo objeto para a Análise do Discurso pois “[...] as diferentes perspectivas pelas quais se observa um fato, ou acontecimento, dão origem a uma multidão de diferentes objetos de conhecimento, cada qual com suas características e propriedades". Deste modo, diferentes analistas do discurso traçam diferentes gestos de interpretação diante de objetos que imaginariamente são tomados como os mesmos, em outros campos metodológicos. Todavia, o gesto de interpretação não se dá de qualquer maneira. De acordo com Orlandi (2012b, p. 19), partindo do fato discursivo, o analista de discurso define o objeto por meio da metodologia, que abarca uma teoria, um corpo de definições, aos quais se enlaçarão às análises advindas das técnicas de análise. Assim, há uma relação entre “[...] o objeto, as técnicas, a metodologia e a teoria [...]”. Nesse sentido, conforme Maldidier (2010), o objeto é pensado ao mesmo tempo em que o dispositivo de análise.

A pesquisa em Análise de Discurso se funda em um dispositivo teórico-metodológico, que, segundo Petri (2013), se constrói em um movimento pendular que perpassa, no vai e vem, a teoria e a análise, enlaçando-as. Ademais, nesse movimento, teoria e análise, se transformam, e abrem campo para a elaboração de conceitos, a partir de gestos de interpretação. Petri (2002, p. 123) aponta que nesse movimento o pesquisador caminha "[...] da teoria para o corpus, do corpus para o arquivo, do arquivo para a teoria, e assim sucessivamente, até construir um dispositivo teórico e analítico satisfatório". Em cada ida teórica, o pesquisador alinhava o dispositivo analítico, cada gesto de interpretação abre possibilidades de análise. Segundo Petri (2013), o movimento pendular tem a inércia como ponto de partida e o ponto inicial do movimento não precisa ser impulsionado pela teoria. A partir do que a autora aponta, consideramos o pêndulo como uma estrutura que possibilita ao pesquisador movimentar-se entre teoria e análise e tecer um gesto de interpretação singular, posto que, cada pesquisador, a partir dessa estrutura, pode fazer sua entrada na pesquisa agitando o pêndulo conforme o ritmo das condições de produção que contornam o objeto simbólico a ser interpretado e também as condições de produção que contornam o fazer analítico. Deste modo, o movimento de cada analista é diferente diante de dado objeto simbólico, que, conforme dissemos com Orlandi 
(2012e), portanto, não se tratará do mesmo objeto simbólico e jamais o mesmo gesto de interpretação.

Ainda segundo Petri (2013), é o gesto de intepretação do analista do discurso que inicia o movimento, imprevisível e imperfeito, pois construído na opacidade. Assim, não importa se esse gesto inciou-se pela teoria ou pela análise. Por outro lado, esse mesmo gesto que inicia a construção de um dispositivo teórico-analítico deve em dado momento colocar um ponto final no movimento, criando um efeito de fim, que abrirá para outras questões. “[...] A metáfora do pêndulo serve também para ilustrar esse movimento, pois, uma vez instalado o pêndulo, é de sua natureza seguir oscilando indefinidamente [...]" (p. 47). Cabe, então, ao analista instalar o efeito de fim. Para os contornos de um efeito de fim, o analista do discurso dispõe de um dispositivo experimental, que não tem relação com o experimentalismo, pois no campo da Análise do Discurso não há "aplicação", como afirma Orlandi (2010). Conforme Mittmann (2007), o percurso metodológico da Análise do Discurso não é linear, e, portanto, tomamos o cuidado de explicitar a ideia de movimento pendular elencado por Petri (2013), o qual poderia causar a impressão de um movimento preso a repetição, sem deslocamentos ou giros. A autora aponta que o pêndulo mais simples conhecido é o do físico francês Jean Bernard Léon Foucault e que, em dadas condições de controle, ele oscilaria de forma regular por toda a eternidade. Assinala então que

[...] O funcionamento do movimento pendular das análises discursivas que contribuem para a construção do 'dispositivo experimental' da Análise de Discurso tem um funcionamento imperfeito, não correspondendo, portanto, à representação que se tem do pêndulo de Foucault. O movimento pendular que se produz sobre a teoria e as análises de discursos sofre resistências e entra em atrito com seu ponto de apoio, sim! Muito embora isso não signifique nenhum prejuízo às partes, pelo contrário: só enriquece o processo (Petri, 2013, p. 43-44).

Retomando Mittmann (2007) temos a dizer que na suspensão do pêndulo, o analista de discurso tem possibilidade de realizar amplos movimentos, e como ressalta Petri (2013) sofrer as resistências, inclusive dos materiais analisados. Aberta a possibilidades múltiplas, a metodologia da Análise do Discurso é contornada por uma teoria específica (Mittman, 2007). Embora não contemple uma metodologia única como as áreas mais formais da linguística, isso não a descaracteriza: “[...] isso não significa não ter metodologia de análise, bem como não significa que qualquer um sob um pretexto qualquer possa desenvolver um dispositivo teóricoanalítico em Análise do Discurso [...]” (Petri, 2013, p. 41). Mittmann (2007) acrescenta que dependendo do recorte teórico-analítico, diferentes caminhos podem ser percorridos, porém 
esses caminhos são delineados pelo quadro epistemológico fundado por Pêcheux, em que o linguístico e o histórico compõem uma teoria do discurso que é atravessada pela teoria psicanalítica. A partir desse lugar teórico, o que o analista de discurso faz não é “[...] uma descrição do texto, mas uma teorização sobre o discurso, ou seja, tomamos o texto como unidade lingüística para análise do funcionamento do discurso e de suas condições históricas de produção/leitura [...]" (p. 1).

O texto, conforme Orlandi (2008), é a unidade de análise com começo, meio e fim, ou seja, é o enunciado. Porém, se o tomamos como discurso, ou seja, como efeito de sentido entre interlocutores, o texto não mais se configurará como uma unidade fechada em si mesma, posto que passa a ser referido "[...] ao conjunto de discursos possíveis a partir de um estado definido das condições de produção' [...]" (Orlandi, 2012b, p. 78-79). Assim, tomamos o texto como textualidade, posto que é afetado pela exterioridade (Orlandi, 2007b). De acordo com Orlandi (1996), a exterioridade não é algo "fora" da língua, ela é inerente ao discurso, e opera pelo interdiscurso, naquilo que fala antes, em outro lugar, independentemente, sob o complexo das formações ideológicas.

Seguindo esses apontamentos, dizemos que as relações de sentidos se estabelecem entre o que um texto diz, o que ele não diz, entre o que outros textos dizem. “[...] Essas relações de sentido atestam, pois, a intertextualidade, isto é, a relação de um texto com outros (existentes, possíveis, ou imaginários)" (Orlandi, 2012b, p. 13). Inferimos, desse modo, que essa diferenciação na conceituação do que é texto marca fundamentalmente a diferença entre a análise praticada no método da Análise do Discurso da análise praticada no método da maioria das pesquisas qualitativas, e ainda, quantitativas, que trabalham com o texto como unidade de significação fechada em si mesmo, sem abarcar as condições de produção, as formações discursivas que atravessam dado enunciado, sem trabalhar a textualidade e a intertextualidade, a noção de sujeito como posição no discurso. A partir da perspectiva discursiva, o texto é heterogêneo e enfatizamos que é a peculiaridade do gesto de interpretação do analista de discurso que possibilita esse trabalho com o texto.

Orlandi (2010) aponta que a construção de um dispositivo de interpretação é fundamental para o gesto de interpretação do analista e alerta que "A análise de discurso não se constitui em uma hermenêutica na relação com o texto" (Orlandi, 2012b, p. 158), posto que a linguagem não é transparente e o sentido não está dado. Tendo como referência a noção de funcionamento, é tarefa do analista compreender os processos discursivos e os mecanismos de constituição de sentidos e dos sujeitos. A autora, então, diz que o dispositivo de interpretação deve levar em conta aquilo que Pêcheux afirma: que todo enunciado é linguisticamente 
descritível como uma série de pontos de deriva oferecendo lugar à interpretação, sempre passível de tornar-se outro. É nos pontos de deriva que o analista tece o seu gesto de interpretação, articulando aquilo que é dito no enunciado com aquilo que não é dito, com o que é dito em outro lugar e o mais importante, com a memória do dizer. Assim, a Análise do Discurso não é um método de interpretação, pois ela não atribui nenhum sentido ao texto, ela sim problematiza a relação com o texto, e procura explicitar os processos de significação, os mecanismos de produção de sentidos. (Orlandi, 2012b).

Para Pêcheux (2008), o momento da interpretação e da descrição de um objeto simbólico, não se resumem a fases sucessivas, mas a fases que se alternam compondo um batimento, no qual não se misturam mas deixam marcas uma na outra, se inter-relacionam. Orlandi (2007) diz que não há descrição sem interpretação, e isso implica dizer que não há neutralidade do analista/pesquisador já que também a descrição passa por um gesto de interpretação, de seleção. Conforme Lagazzi (1988, p. 51), na Análise do Discurso “[...] não existe o observador, o pesquisador, o cientista neutro, descomprometido de suas crenças. Afirmar o contrário seria o mesmo que colocar o sujeito fora do alcance da ideologia. [...]”. Todavia, a análise não fica invalidada pelo atravessamento subjetivo, e, conforme Pêcheux (2009a), não há um puro discurso científico.

O método, então, se pauta em procedimentos que dão consistência a teorização e às análises, já que elas não são feitas de qualquer maneira. Quanto ao analista de discurso, podemos dizer que seu dispositivo de interpretação constitui um campo discursivo que lhe possibilita a contemplação dos processos ideológicos, a partir do amparo de seu dispositivo teórico para tecer leituras no entremeio do processo de descrição e interpretação. É uma leitura/interpretação que se diferencia da leitura do leitor comum, que é desamparado da teoria e é não ciente do atravessamento ideológico e do recalque inconsciente que opera na determinação de certos sentidos e no silenciamento (Orlandi, 2007a) de outros. Conforme Pêcheux (1999), a interpretação é incontornável e sempre retornará pela própria opacidade do objeto, quando analisado na perspectiva da Análise do Discurso.

Esse efeito de opacidade (correspondente ao ponto de divisão do mesmo e da metáfora), que marca o momento em que os implícitos não são mais reconstruíveis, é provavelmente o que compele cada vez mais a Análise de Discurso a se distanciar das evidências da proposição, da frase e da estabilidade parafrástica, e a interrogar os efeitos materiais de montagens de sequências, sem buscar a princípio e antes de tudo sua significação ou suas condições implícitas de interpretação (p. 53-54). 
Desse modo, esse campo se diferencia da linguística e de todos os demais campos científicos que trabalham com a evidência dos sentidos, com a neutralidade do pesquisador e com a transparência da língua, a onisciência do sujeito. Tal diferença se sustenta no gesto de interpretação do analista que é pautado, como dissemos, em um dispositivo de interpretação, que possibilita a construção de um dispositivo teórico e um dispositivo analítico, os quais compõem o dispositivo teórico-metodológico do analista/pesquisador, no movimento pendular bem indicado metaforicamente por Petri $(2002,2013)$. Destacamos que o dispositivo teórico é composto por conceitos delineados tanto pela Análise do Discurso quanto por outras áreas que auxiliam o analista de discurso a tecer seu gesto de interpretação. O dispositivo analítico, podemos dizer que também contempla o dispositivo teórico, e é composto por um tratamento do material bruto coletado para as análises e esta é realizada em etapas, conforme veremos.

Para abordarmos o dispositivo analítico, apontamos com Lagazzi (1988, p. 59) que, “[...] a partir de um universal discursivo, um conjunto potencial de discursos que podem ser objeto de análise, estabelecemos um campo discursivo de referência $[. .$.$] ”. Em outras palavras, a partir$ do material bruto coletado, chamado também por "superfície linguística", o analista de discurso tece um primeiro tratamento de análise superficial que vai "de-superficializar" o objeto discursivo a ser analisado. Nesse processo, opera a noção de "recorte", que, segundo Orlandi (1984, p. 14), “[...] é uma unidade discursiva [...], é um fragmento da situação discursiva”, e complementa: “[...] O recorte é naco, pedaço, fragmento. Não é segmento mensurável em sua linearidade" (p. 16). Tomamos essa noção para apontar que ela é ferramenta do gesto de interpretação do analista de discurso, que, com sua tesoura, destaca da teoria os conceitos a serem trabalhados, e, da superfície linguística, os nacos discursivos que serão analisados. Enfatizamos, ainda, que a linearidade não faz parte desse processo, e sim o movimento pendular, do ir e vir, em que teoria e análise se atravessam, e constituem o objeto simbólico a ser interpretado, no gesto autoral do analista de discurso.

O objeto discursivo, portanto, requer um trabalho do analista, que vai decidir as sequências discursivas, ou ainda, recortes, que comporão o corpus, que é o conjunto de sequências discursivas elencadas para interpretação (Orlandi, 2010), conforme Courtine (1981) o define. Segundo Lagazzi (1988), é possível ao analista de discurso, a partir da análise dos mecanismos sintáticos, aproximar-se do funcionamento enunciativo do objeto discursivo linguisticamente desuperficializado. Tal objeto discursivo passa pela desintagmatização discursiva e o analista desvela o processo discursivo, explicitando relações entre o que foi dito, o que não foi dito, no trabalho com a intertextualidade. A autora acrecenta que é pela desintagmatização discursiva que o analista vislumbra a formação discursiva que domina o 
texto e a relação desta formação discursiva com outras que o atravessam, e que representam as formações ideológicas. Mas para aí chegar é preciso o suporte das condições de produção, pois estas permitem explicar o funcionamento discursivo pelo dado de memória e historicidade.

Lagazzi (1988) nos lembra que, conforme Courtine (1982) e Pêcheux (2009a), a contradição é o princípio constitutivo de toda formação discursiva e que os limites de uma formação discursiva, assim como de uma formação ideológica, não são fixos, devem ser pensados como uma reconfiguração incessante, em que os limites se deslocam em função das posições ideológicas da formação discursiva em dada conjuntura. Segundo Mittmann (2007), no gesto do analista recortar sequências discursivas, relacioná-las a uma memória, elencar formações discursivas onde se dão os pontos de enlace e desenlace com alguns sentidos, também está o gesto de trabalhar com os poros, as fendas da rede de memória e do silêncio. Relacionando a formulação (intradiscurso) e o enunciado (os saberes de uma formação discursiva), o recorte e o arquivo, o analista vai costurando o corpus, vai retrançando

[...] paráfrases do processo discursivo, ressonâncias de uma mesma posição de sujeito, ressonâncias de uma mesma Formação Discursiva, ressonâncias de outras Formações Discursivas que estão em relação de aliança com esta. Retrançando as dissonâncias entre posições de sujeito numa mesma Formação Discursiva, retraçando o percurso dessa dissonância pela relação com o Interdiscurso. Redescobrindo e produzindo, constantemente, efeitos de sentido, deslizamentos, metáforas [...]. (Mittmann, 2007, p. 2).

Para Mittmann (2007, p. 2-3), o limite de uma formação discursiva é determinado pelo conflito com outras formações discursivas, e é a partir da teorização que é possível ao analista delimitar o conjunto de enunciados pertencentes a uma formação discursiva. Segundo ela, o analista vai levantando questões como: “[...] as formulações são produzidas a partir de uma mesma posição de sujeito? De uma mesma Formação Discursiva? De uma mesma Formação Ideológica? Produz-se o mesmo efeito de sentido quando uma formulação é produzida em meio a uma seqüência de outras? [...]”. Em relação a posição-sujeito, podemos dizer que, assim como as formações discursivas, elas podem ser plurais em um dado texto, em uma dada sequência discursiva. Ou seja, as “[...] diferentes posições do sujeito no texto correspondem a diversas formações discursivas. Isto se dá porque em um mesmo texto podemos encontrar enunciados de discursos diversos, que derivam de várias formações discursivas” (Orlandi, 2012b, p. 71), às quais se somam formas-sujeito que ressoam em posições-sujeito. Nesse gesto de interpretação, podemos assinalar, em contrapartida, os efeitos da ideologia produzindo a aparência da unidade 
do sujeito e do sentido, evidências que são postas em questão na análise do processo de produção dos sentidos, trabalho do analista de discurso. Para Orlandi (2012b, p. 78)

\begin{abstract}
A formação discursiva é, enfim, o lugar da constituição do sentido e da identificação do sujeito. É nela que todo sujeito se reconhece (em sua relação consigo mesmo e com outros sujeitos) e aí está a condição do famoso consenso intersubjetivo (a evidência de que eu e tu somos sujeitos) em que, ao se identificar, o sujeito adquire identidade (Pêcheux, 1975). É nela também, como dissemos, que o sentido adquire sua unidade.
\end{abstract}

A autora apresenta também que além das condições de produção de um enunciado há as condições de formação da formação discursiva que se inscreve no enunciado, e salienta que da articulação destas é que deriva o campo da memória da sequência discursiva. De acordo com Lagazzi (1988, p. 60), "na Análise do Discurso, a apreensão das marcas não é automática e também a interpretação dos seus sentidos não é mecânica. O objetivo do pesquisador, suposto pelo método discursivo e constitutivo deste, é o fator determinante para o que será privilegiado no material tomado para análise". Portanto, é trabalho de análise o estabelecimento do corpus, o qual, segundo Orlandi (2010), se organiza a partir da pergunta do pesquisador e é delimitado e trabalhado a partir da intervenção téorica, que rege a relação do analista com o objeto, com os sentidos e com a interpretação. É um trabalho de tessitura, como aponta Petri (2013) e Mittmann (2007), de ir e vir, para a constituição do corpus, que podemos dizer também é corpus teórico já que em Análise do Discurso, o "batimento" de que nos fala Pêcheux (2008) entre os conceitos e o objeto simbólico a ser interpretado, é perpassado de elaboração teórica feita não apartada de análises.

Tendo em vista o que traçamos até o momento sobre o método em questão, apresentamos um mapa sobre o trabalho de análise que, conforme Orlandi (2010), passa por três etapas, as quais auxiliam o analista de discurso em seu gesto de interpretação. A primeira etapa de análise é composta pelo momento em que o analista busca a discursividade do texto, trabalhando, assim, com a textualidade e a intertextualidade, e constrói um objeto discursivo desfazendo o efeito do esquecimento $n^{\circ} 2$, qual seja, a ilusão de que só se poderia dizer tal coisa de dada maneira, desnaturalizando, assim, a relação palavra-coisa. Na segunda etapa, a partir do trabalho feito na etapa anterior, o analista passa a trabalhar as formações discursivas que dominam o objeto discursivo. Na terceira etapa, tece uma análise do objeto discursivo relacionando as distintas formações discursivas com a formação ideológica dominante. Percorrendo essas etapas, o analista atinge a constituição dos processos discursivos que causam os efeitos de sentido produzidos, e diante de paráfrases, deve observar os efeitos metafóricos, 
os deslizamentos de sentidos presentes no objeto simbólico analisado. Apontamos, ainda, que não se trata de um passo a passo hermético, mas de um caminho possível para trabalhar o processo de construção dos sentidos e dos sujeitos, a partir do gesto de interpretação do analista.

Podemos articular essas etapas, o procedimento de constituição do corpus, enfim, a construção do dispositivo teórico-metodológico realizada pelo analista de discurso, ao que Ginszburg (1989) diz sobre o paradigma indiciário. Esse autor delineia as nuances desse paradigma que se dedica ao estudo dos "[...] pormenores mais negligenciáveis [...]" (p. 144) de um objeto simbólico, e traça as raízes históricas desse paradigma no paradigma venatório, o qual é bem representado pelo caçador agachado no chão buscando pistas de sua caça. Trazemos essas associações para dizermos do trabalho do analista de discurso com o seu material de análise, a busca de nuances que levam ao processo de constituição dos sentidos. Conforme Sousa, Garcia e Faria (2014, p. 96),

[...] nesses termos todos nós, que trabalhamos com a metodologia da teoria discursiva francesa, encontramo-nos debruçados diante do texto como caçadores de pegadas do sujeito, de secreções de sentidos e de vestígios da estrutura e do acontecimento, tocando os suores do enunciado pelo que escorrega às margens. Não nos interessa a mensagem como bloco fechado, mas as fissuras que ela conserva, o minúsculo de um pelo esquecido em um passo de equívoco, em uma troca de palavra e de som, em um caco de desarranjo que reclama acuidade de escuta.

Articulando também o paradigma indiciário ao movimento pendular delineado por Petri (2013), trazemos associações com Mittmann (2007, p. 1) que aponta que “[...] como pesquisadores, acionamos nossa habilidade de arquivistas, buscando, resgatando, selecionando textos [...]", seleção na qual fazemos a opção por um tema, um campo discursivo, uma entrada para a análise, e, diante das várias direções que se expõem ao analista, seu olhar curioso e sua escuta atenta vão definindo um caminho. Um caminho de vai e vem, em que cabe olhar de novo, costurar a teoria, avivar a análise, opacizar sentidos, escutar de outro modo e criar um efeito de fechamento que, em verdade, abre para novas questões. "[...] Percorremos cada texto, relacionamos com a história, pensamos o linguístico em relação com o ideológico e com o inconsciente [...]” (p. 1). Isso porque, como nos lembra Pêcheux (2008, p. 53), “[...] o humor e o traço poético não são o 'domingo do pensamento' [...]”'. 


\subsection{O processo de produção desta pesquisa}

Tentar registrar em palavras o processo de produção da pesquisa que aqui se apresenta é se dar conta de um impossível, pois o movimento pendular que foi sustentado no gesto de interpretação, o movimento de ir e vir inerente ao enlaçamento entre teoria e análise, escapa a qualquer apreensão que intente detalhar o processo tal como se constituiu, podendo dele ser retomado apenas algumas marcas que indiciam que houve um percurso. Esperamos que essas marcas possam transpirar algo do movimento presentificado no olhar e na escuta dedicados a um objeto simbólico, qual seja, o estudo de questões a partir de discursos e sentidos sobre a relação sujeito, corpo e objetos tecnológicos de conexão à rede eletrônica, tema relativamente novo e com o qual mantivemos íntima relação a cada letra teclada. Isso porque foi na relação com um objeto tecnológico que escrevemos e inscrevemos esse movimento de ir e vir. Ou seja, essa escrita, ancorada em um campo discursivo legitimado, o campo acadêmico-científico, perpassou o contato do nosso corpo com o computador. A partir desse objeto, a pesquisa ganhou corpo-escrito-digitado pois ela não poderia ser apresentada de outro modo, dado que uma pesquisa manuscrita ou datilografada no campo no qual nos incluímos como sujeitospesquisadores não se enquadra na estabilização normativa, com o fim de formalização, à qual estamos assujeitados. Também foi na relação com a rede eletrônica que tecemos nossas buscas da pesquisa, seja por materialidades teóricas, seja por materialidades destinadas à análise. Foi, então, nessa relação diária, de um corpo a corpo com o objeto tecnológico e com a rede eletrônica, que se deu o processo de constituição, de formulação e de produção desta pesquisa.

Com base nessas colocações, podemos apresentar o quanto o sujeito-analista está implicado na produção de um discurso, desde aquilo que ele elenca como objeto simbólico até as relações que estabelece com esse objeto para tecer seu gesto de interpretação. O sujeitoanalista, como já dissemos, é atravessado pela ideologia, pela ideologia de seu tempo, e, assim, é também atravessado pelos enunciados do Mercado (Payer, 2005). Contudo, construir um dispositivo teórico e analítico já é anunciar estar em uma posição advertida desses atravessamentos e estar disposto a operar com a falha no ritual (Pêcheux, 2009b), a ousar a pensar por si mesmo e a resistir à captura cega dos sentidos legitimados. É também buscar o que Agamben (2009) propõe, um olhar contemporâneo, ao que acresentamos, uma escuta também contemporânea. Um olhar e uma escuta, como dissemos na apresentação da tese, que intenta se desprender do controle temporal, ao mesmo tempo em que no tempo se situa, para contemplar as materialidades do seu tempo. 
Assim nos posicionando, buscamos não nos fixar tanto em nossa época, e para isso, acessamos a historicidade, seja do corpo, seja do objeto (tecnológico), para percebermos que o corpo e o objeto ganham contornos discursivos diferentes a cada contexto sócio-histórico. Porém, há uma relação que é repetitória em qualquer contexto sócio-histórico, que é a busca do sujeito por uma complementariedade na relação do corpo-objeto, do objeto-corpo, bem delineadas por Freud (1930/2010) e Lacan (1995, 2005), no campo da Psicanálise, e por Pêcheux (2009a, 2008, 2010), no campo da Análise do Discurso. Buscamos, portanto, olhar e escutar no escuro de nosso tempo e não nos cegarmos com as luzes efusivas que nele se produzem, e tecemos nossos movimentos.

O gesto de interpretação que deu início ao movimento pendular materializado nessa pesquisa, construído na opacidade, se constituiu a partir de pesquisa anterior que nos sensibilizou para a escuta aos sentidos legitimados sobre o corpo na pós-modernidade. Tal pesquisa formalizada na dissertação de mestrado "Sentidos de inclusão e exclusão na voz de sujeitos escolares: o deslocamento do déficit pela via da falta" (Giorgenon, 2011), objetivou estudar discursos sobre crianças e adolescentes considerados com deficiência na inclusão escolar e, a partir dela, ampliamos nossa escuta à imputação de déficit e potência ao corpo. Ao mesmo tempo, em nossos estudos realizados no "Laboratório Discursivo: sujeito, rede eletrônica e sentidos em movimento - E-1@dis", atentas ao campo cibernético, encontramos materialidades discursivas na rede eletrônica sustentando sentidos de "potência" ao corpo ao estar conectado a um objeto tecnológico de conexão à rede eletrônica, via potência suposta do objeto. Passamos a levantar, então, questões sobre a imputação de déficit e potência ao corpo, para além dos sentidos já legitimados nos padrões de normalidade advindos do saber médico, sustentados, no caso das materialidades encontradas, no campo cibernético pelo poder do Mercado (Payer, 2005), mais especificamente, pela mídia.

A partir desse percurso e do movimento pendular já instalado na passagem de uma pesquisa em processo de conclusão, a dissertação de mestrado, e outra que estava se constituindo, a tese de doutorado, sustentamos o desejo de estudar discursos sobre a relação sujeito, corpo e objetos tecnológicos de conexão à rede eletrônica materializados na rede eletrônica e também fora dela. Vislumbrando materialidades discursivas que apresentavam o corpo fusionado a máquina, o corpo silenciado perante a máquina e o corpo ilimitado na conexão com a máquina, formulamos três questões a fim de estudar o processo de produção desses sentidos. Tais questões nortearam a constituição de nosso dispositivo teórico e analítico, ao mesmo tempo em que elas próprias já adviram de um olhar e uma escuta em movimento, e assim se constituíram: 
1) Como os discursos sobre os objetos tecnológicos de conexão à rede eletrônica fazem do corpo uma peça acoplada, unindo o corpo e a máquina?

2) Como os discursos sobre os objetos tecnológicos de conexão à rede eletrônica tornam o corpo silente, parado, ao passo que é supostamente movente na rede?

3) Como os discursos sobre os objetos tecnológicos de conexão à rede eletrônica tecem sentidos sobre o corpo como não tendo limite para o gozo com o objeto, o acoplamento, o acesso?

O corpo dessa tese, constituído de partes (capítulos) ao mesmo tempo em que se configura formalmente com um "semblante" de todo, advertido do "não-todo" (Lacan, 1985) e movido pela causa do desejo, na movência, buscou enlaçar e desenlaçar as materialidades do campo do saber produzidas por autores da Análise do Discurso, da Psicanálise, da Linguística, do Materialismo Histórico, da Filosofia, da Antropologia, da Sociologia e da Cibercultura às materialidades discursivas encontradas na rede eletrônica; materialidades que compuseram nosso dispositivo teórico e analítico. Assinalamos que, cada movimento na rede eletrônica na busca por materialidades discursivas, produzia novas buscas de articulações teórico-analíticas em livros, em artigos, em disciplinas, em trocas de orientação acadêmica com a professora doutora Lucília Maria Abrahão e Sousa, produzia interlocução com colegas, produzia presença em eventos científicos, produzia artigos. Produzia o movimentar-se, o ir e vir, assim como o ir e vir inerente ao processo de produção da pesquisa, entre teoria e análise. Assim, nos movimentamos até a terra de Pêcheux e de Lacan para lá também tecer laços de interlocução, possíveis por meio do estágio de doutorado sanduíche, financiado pelo Programa de Doutorado Sanduíche no Exterior da CAPES (Bolsista - Processo BEX10793/14-3), tendo como coorientador o psicanalista, professor doutor Éric Bidaud, da Université Paris 13 - Nord. Estágio no qual levamos a rica produção brasileira de estudos sobre o discurso, sujeito, corpo e objetos tecnológicos para a França, assim como participamos de seminários de psicanálise, do campo do materialismo histórico, da teoria do discurso, da linguística, tecendo também importante interlocução com o linguista, professor doutor Christian Puech, da Universite Paris 3 Sorbonne Nouvelle.

Sublinhamos que cada troca avivada por laços transferenciais, abria nosso olhar e nossa escuta às materialidades que fomos encontrando ao longo do percurso. Torna-se importante dizer que as materialidades discursivas que compõem as análises foram encontradas ao navegarmos pela rede eletrônica e na rede social Facebook; deste modo, também fomos surpreeendidas, às vezes, com aparições discursivas inesperadas, quando não as estávamos procurando (se é que isso é possível), e de modo mais incisivo as encontramos em sites e blogs 
brasileiros de divulgação de objetos tecnológicos de conexão à rede eletrônica, por meio de buscadores como Google e DuckDuckGo e de palavras-chave como, por exemplo, "gadgets", “corpo e internet", "novas tecnologias e internet", "tecnologias vestíveis". Sublinhamos que o material que comparece na tese, é parte, uma pequena parte do material discursivo encontrado, pois, como dissemos, na Análise do Discurso não há uma preocupação com a extensão quantitativa dos recortes a serem analisados, mas, sim com a profundidade das análises realizadas com recortes que são representativos de um campo discursivo repetitório, parafrástico. As materialidades foram coletadas no período de agosto de 2012 a agosto de 2014. No caso dos objetos tecnológicos óculos e lente de contato que conectam a rede eletrônica, há recortes datados desde 2008, respeitando a data de postagem das notícias sobre esses objetos, já que buscamos escutá-los desde sua primeira aparição na rede eletrônica.

As partes da tese (capítulos), como é possível observar ao longo do trajeto percorrido até aqui, se formulam em um batimento entre teoria e análise, cada uma delas trazendo recortes discursivos e gestos de interpretação. Todavia há uma concentração de gestos analíticos no capítulo 5, dedicado à formalização de análises com a articulação da produção do percurso da pesquisa, ou seja, a posição-sujeito corpo (inter)face, associada a forma-sujeito do mercado e à formação discursiva do mercado, que pudemos depreender das contribuições de Payer (2005). Posição-sujeito que nos auxilia a compreender o processo de produção dos sentidos e dos discursos sobre o corpo, legitimados e silenciados pela ideologia pós-moderna. Na partição da tese, enquanto estrutura cindida, castrada, faltante, que tomou corpo no movimento pendular, pudemos apresentar uma partição do corpo nos discursos sobre os objetos tecnológicos de conexão à rede eletrônica na medida em que, ao se acoplarem à face ou ainda mais precisamente ao olho, que é uma parte do corpo, um órgão, destituem outras partes, ofertando a ideia de um corpo que pode se mover incessantemente na rede eletrônica, ao passo que só necessita do movimento do olho. Órgão que supostamente torna-se potente no campo da visão, ao interfacear o objeto tecnológico.

Do material bruto coletado, selecionamos sequências discursivas e imagéticas, as quais foram analisadas ao longo dos capítulos, como dissemos. Todavia, selecionamos 15 recortes, representativos de paráfrases sobre a relação sujeito, corpo e objetos tecnológicos de conexão à rede eletrônica, mais especificamente os óculos e as lentes de contato que prometem conexão à rede eletrônica e à realidade aumentada. Esses recortes foram aglutinados em entradas discursivas norteadas pelas questões 1,2 e 3 e pelo que vislumbramos de sentidos sobre o corpo ou partes do corpo nos discursos sobre os objetos tecnológicos de conexão à rede eletrônica. Nomeamos as entradas discursivas como: 1) Sentidos sobre o silenciamento do corpo no 
acoplamento com o objeto tecnológico de conexão à rede eletrônica. 2) Sentidos de invocação de partes do corpo para o acoplamento com o objeto tecnológico de conexão à rede eletrônica e destituição de outras partes. 3) Sentidos de potencialização de partes do corpo no acoplamento com o objeto tecnológico de conexão à rede eletrônica

O fato de um recorte discursivo ser alocado na Entrada Discursiva 1, por exemplo, não quer dizer que ele não seja atravessado pelas questões materializadas nas Entradas Discursivas 2 e 3. Apontamos, assim, que se trata de uma distribuição que, apoiada no nó borromeano, ilustra que as entradas discursivas, assim como as questões que norteiam a tese, estão entrelaçadas, tal qual imaginário, simbólico e real, e que, abordar cada uma separadamente tem uma função que visa a captar os sentidos que se destacam e que são silenciados em cada uma dessas entradas. Como dissemos, as sequências discursivas são representativas de paráfrases discursivas, ou ainda, de sentidos que, na ordem da repetição, abordam a relação sujeito, corpo e objetos tecnológicos de conexão à rede eletrônica no campo da fusão, do silenciamento do corpo, da fragmentação, da potencialização de partes do corpo e do empuxo ao ilimitado.

Embora o sujeito possa ocupar várias posições-sujeito no discurso, optamos por abordar a especificidade de uma posição-sujeito, que nomeamos corpo (inter)face, conforme a delineamos no capítulo 3 , na seção 3.4. Tal posição-sujeito foi concebida a partir do gesto de interpretação às materialidades discursivas, gesto com o qual desfizemos os efeitos dos esquecimentos, ou seja, os efeitos de uniformização dos sentidos, e tecemos articulações com o que Payer (2005) apontou sobre os enunciados do Mercado. Assim, no movimento de ir e vir entre teoria e análise, construímos nosso dispositivo teórico e analítico, a partir do qual pudemos conceber a formação discursiva e a forma-sujeito do mercado, a partir dos apontamentos de Payer (2005) e a posição-sujeito corpo (inter)face a partir de toda a teoria alinhavada nos três capítulos iniciais. Se, por um lado, buscamos escutar os "pormenores mais negligenciáveis" (Ginszburg, 1999) nas análises, buscamos também um efeito de fim posto que, como afirma Pêcheux (1999) a interpretação é incontornável e retorna sempre. Passemos aos indícios. 


\section{INDÍCIOS DA FORMAÇÃO DISCURSIVA DO MERCADO, DA FORMA-SUJEITO DO MERCADO E DA POSIÇÃO-SUJEITO CORPO (INTER)FACE NO DISCURSO}

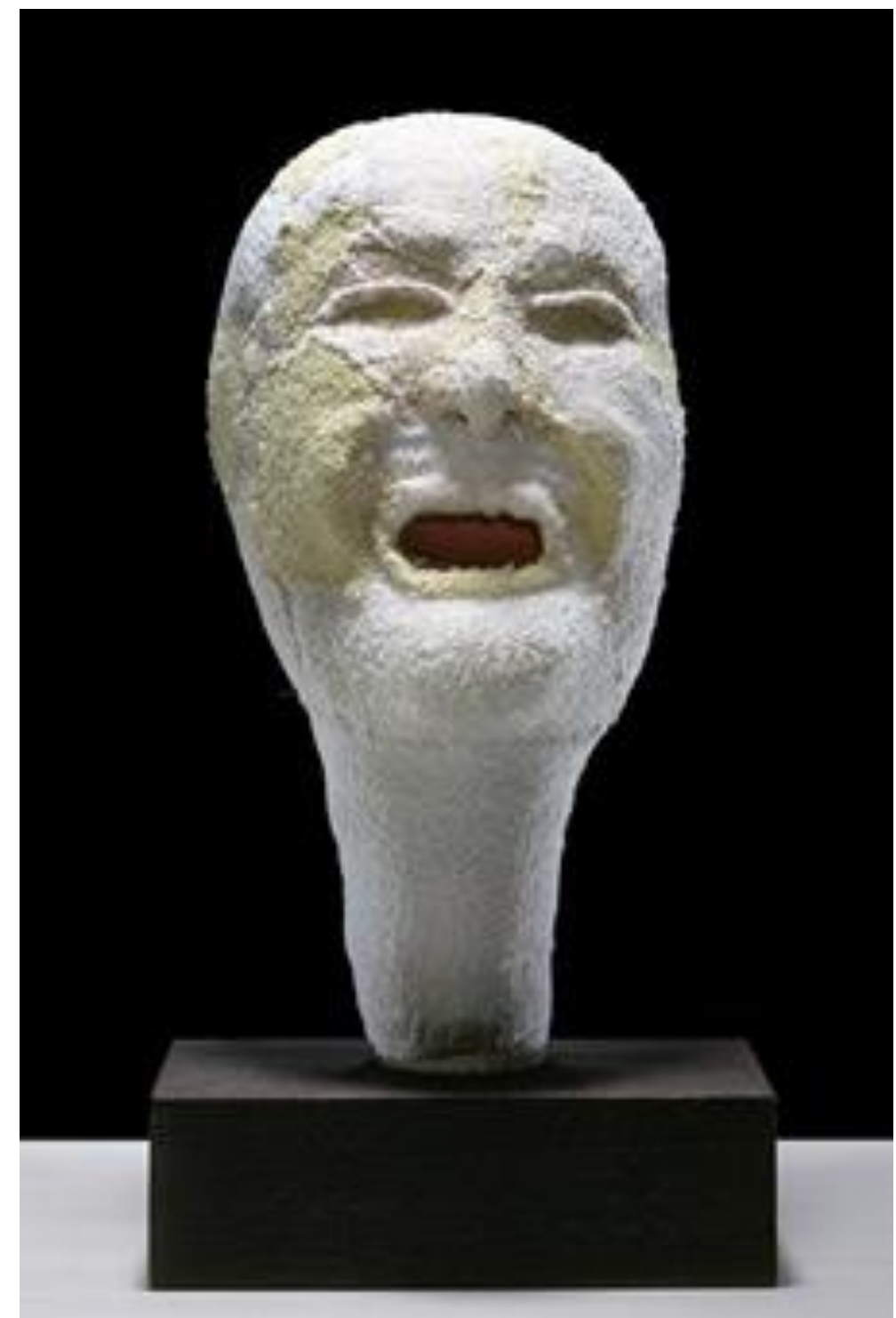

Rejection (Louise Bourgeois, 2001)

O Outro lado

[...] Esqueci-me de que as coisas são mais espertas do que parecem e não se deixam enganar com essa facilidade: elas sabem muito bem que no interior de cada máquina fotográfica há um olho humano escondido... Além disso, ainda que o aparelho, por astúcia, tivesse podido captar a imagem frontal de uma coisa, sempre o outro lado dela ficaria fora do alcance do sistema óptico, mecânico, químico ou digital do registro fotográfico. Aquele lado oculto para onde, no derradeiro instante, ironicamente, a coisa fotografada teria feito passar a sua face secreta, essa irmã gémea da escuridão. Quando numa habitação imersa em total obscuridade acendemos uma luz, a escuridão desaparece. Então não é raro perguntarmo-nos: 'Para onde foi ela?'. E a resposta só pode ser uma: 'Não foi para nenhum lugar, a escuridão é simplesmente o outro lado da luz, a sua face secreta' [...]" 
"Um mundo semanticamente normatizado", começando pela "[...] relação de cada um com seu próprio corpo e seus arredores imediatos [...]” (Pêcheux, 2008, p. 34). É nessa concepção que, ao nosso ver, se filiam os discursos sobre os objetos tecnológicos de conexão à rede eletrônica, ao apresentá-los como aqueles que suprirão, seja o corpo, seja o mercado, na ordem da potência. A “urgência humana”, bem delineada por Pêcheux (2008), por uma estrutura homogênea, representável, também do corpo, não deixa de tentar se materializar e, não deixa de se materializar pela via de uma "ciência régia", produtora de objetos tecnológicos, que são legitimados pelo poder do Mercado (Payer, 2005). Tal poder, como temos escutado, produz sentidos de naturalização de um corpo ciborgue, potente com a máquina, um corpo normatizado, regulado por portar objeto tecnológico. Ao sujeito se filiar aos seus modos de emprego, nos discursos que analisamos, faz reverberar um efeito de univocidade, como se só houvesse um modo de dizer do corpo e um modo de dizer do objeto tecnológico. Parafraseando Pêcheux (2008) com Freud (1930/2010), como o ser humano poderia resistir a tal pechincha de ilusoriamente ter o objeto que supostamente potencializaria seu corpo? Um objeto que, como vimos no capítulo 2, se miniaturiza e se acopla a face, ao olho, como é o caso dos objetos tecnológicos de conexão à rede eletrônica e que propiciam a realidade aumentada: óculos e lentes de contato.

O Mercado, materializado na formação discursiva do mercado, enlaça os sujeitos na busca da potência, do sucesso, da visibilidade e faz legitimar tais sentidos na relação com o objeto tecnológico de conexão à rede eletrônica. Como aponta Braunstein (2010), a serviço do mercado, o saber científico (parte dele) se encarrega da produção de "servomecanismos", descartáveis, aos quais o sujeito se consagra no discurso do mercado que esvai de sua boca (Brausntein, 2010). Como vimos com Pêcheux (2009a), a língua é a base para os processos discursivos e nesses processos vigoram a ideologia e o recalque do inconsciente e, se pelo efeito dos esquecimentos, é possível produzir a ilusão de unicidade dos sentidos, por outro lado, a desestabilização, também constitutiva da língua, do discurso e do sujeito, pelo próprio movimento dos processos de imposição e dissimulação, e suas brechas, produz também as falhas no ritual.

Assim, assinalamos que, na esteira de Pêcheux (2008) e da Psicanálise, colocar em causa as evidências da língua, significa abrir questões para dar voz a desestabilização dos sentidos. Desse modo, procuramos, ao longo da escrita da tese, apresentar os sentidos herméticos, mas também outros sentidos, fazendo a desestabilização comparecer na suposta homogeneidade. Isso porque como Orlandi (2007a) aponta, dizer é silenciar e, portanto, acompanharemos também o processo de produção de sentidos silenciados na relação sujeito, corpo e objetos 
tecnológicos de conexão à rede eletrônica. Advertidos de nosso atravessamento ideológico e inconsciente, dizemos que o nosso olhar e a nossa escuta aos sentidos sobre a referida relação persistem faltantes, não apreenderão e nem pretendem apreender o todo, pois trabalhamos com o não-todo (Lacan, 1985), e só essa consideração já aponta que os sentidos legitimados não são os únicos modos de dizer, assim como, que os sentidos que colocaremos à tona, não são os únicos faltantes e silenciados.

Para tecermos nossas análises, nos apoiamos em Payer (2005) para dizer da formação discursiva do Mercado e da forma-sujeito do Mercado, com as quais o sujeito se identifica, nos processos de subordinação/assujeitamento ao Sujeito universal, ou seja, ao poder do Mercado. Dissemos identificação posto que foi a modalidade discursiva sobrevalente nas materialidades discursivas que encontramos. Formulamos a posição-sujeito corpo (inter)face para escutarmos os discursos sobre os objetos tecnológicos, que incidem em sentidos sobre o corpo, visando a opacizar a noção de ciborgue, bem como estabelecermos um gesto de interpretação às materialidades encontradas na rede eletrônica amparadas pelo dispositivo teórico metodológico da Análise do Discurso.

Buscamos escutar a memória que sustenta os dizeres a partir da historicidade do corpo e marcamos as repetições, as regularizações e as atualizações de sentidos sobre um corpo potente, almejado ao longo da história, seja pela busca de um mundo semanticamente normatizado como disse Pêcheux (2008), seja pela busca do objeto que ilusoriamente completaria o sujeito como disse Freud (1930/2010) e Lacan (1995). Apontaremos também como o acontecimento discursivo que perturba a memória desregulando a série (Pêcheux, 1999) pouco comparece nos discursos, posto que a saturação dos sentidos, não abre espaço para nenhum outro, enquanto retumba um tom de "acontecimento" no sentido de um "anúncio" em cada nova invenção.

Conforme Schons e Mittmann (2009, p. 295), "trabalhar com o discurso em AD consiste em investigar o processo de imbricamento da materialidade histórica com a materialidade linguística, buscando desfazer os efeitos provocados pelo próprio processo. [...]", efeitos de univocidade, linearidade e transparência da língua e da história que incidem nos discursos, e, portanto, nos sujeitos. Para as autoras, tais efeitos só podem ser desfeitos considerando-se a exterioridade em um processo que lance um olhar para o teatro da consciência. Conforme Orlandi (2015, p. 211), “[...] todo corpo está investido de sentidos enquanto corpo de um sujeito que se constitui por processos nos quais as instituições e suas práticas são cruciais, da mesma forma que, ideologicamente, somos interpelados em sujeitos [...]”. Assim, com essas autoras, trazemos um corpo ligado ao corpo social que não é da ordem da transparência. 
Visando a desestabilizar espaços discursivos legitimados pela ideologia do poder do Mercado, nos quais prevalecem uma cobertura lógica, uma homogeneidade nas proposições acerca dos objetos tecnológicos de conexão à rede eletrônica, óculos e lente de contato que conectam a rede eletrônica e propiciam a realidade aumentada, e nos quais também prevalecem uma impressão de autonomia do sujeito, teceremos as análises de recortes discursivos, selecionados dentre diversos outros, os quais distribuímos em três entradas discursivas, que abordam o silenciamento do corpo em pról de sentidos sobre ciborgue e ficção científica; a invocação do olho para a conexão com o objeto tecnológico e a destituição de outras partes do corpo; e os sentidos de potencialização do olho/corpo e deslimites para o gozo com o objeto tecnológico.

Destacamos que nessas entradas discursivas pulsam as três questões que norteiam essa pesquisa, quais sejam: 1) Como os discursos sobre os objetos tecnológicos de conexão à rede eletrônica fazem do corpo uma peça acoplada, unindo o corpo e a máquina? 2) Como os discursos sobre os objetos tecnológicos de conexão à rede eletrônica tornam o corpo silente, parado, ao passo que é supostamente movente na rede? 3) Como os discursos sobre os objetos tecnológicos de conexão à rede eletrônica tecem sentidos sobre o corpo como não tendo limite para o gozo com o objeto, o acoplamento, o acesso? Apontamos que, embora cada entrada discursiva e cada questão remeta a um ponto específico da relação sujeito, corpo e objetos tecnológicos de conexão à rede eletrônica, como dissemos no capítulo anterior, tal como o nó borromeano elas estão enlaçadas, e, assim se dispõem separadamente para fins de interpretação, mas se tocam estabelecendo interlocução umas com as outras, posto que a exterioridade é constitutiva dos discursos.

\subsection{Entrada discursiva 1: Sentidos sobre o silenciamento do corpo no acoplamento com o objeto tecnológico de conexão à rede eletrônica}

Abordaremos o processo de produção de silenciamento do corpo em alguns recortes e apontaremos sentidos sobre o corpo na transpiração dos significantes. Se o corpo faltante é velado no processo de produção dos discursos que analisamos, apontaremos como a formação discursiva do mercado ventilada na posição-sujeito corpo (inter)face se ampara em sentidos sobre o ciborgue e sobre a ficção científica para dizer da potência na relação com os objetos tecnológicos óculos e lentes de contato, apoiando-se na ciência. Assim, os sentidos analisados 
nessa Entrada Discursiva, apoiam-se no sentido de "científico", tanto na ficção quanto na realidade.

Segundo Pêcheux (2009a), a forma-sujeito impõe a realidade ao sujeito sob a forma do desconhecimento de modo que a "ficção" representa a modalidade mais pura da identificação com a forma-sujeito do discurso. Entrelaçando ficção e realidade, já que esta última é também permeada por aquela, apontamos o quanto a relação sujeito, corpo e objetos tecnológicos é permeada por sentidos que marcam um deslocamento da ficção para a realidade, separando-as em quadrantes distintos. Nas materialidades que recortamos, destacamos que para (não) dizer sobre o corpo faltante, a referida relação é sintetizada em dizeres sobre o ciborgue, personagem de histórias de ficção científica, e, segundo Lemos (2010), personagem cotidiano, cada um de nós, ciborgues interpretativos por influência dos mass media, ciborgues protéticos pela relação de colamento com o objeto.

Opacizando esses sentidos, apontamos que, na transparência dos sentidos de potência atribuído aos ciborgues, o corpo faltante é silenciado ao se criar efeitos de completude na relação com o objeto, visto que a formação discursiva do mercado, ao propagar sentidos de potência para os objetos, vendem sentidos de potência para o corpo, que passa a ser tomado como ciborgue, misto de máquina e organismo (Haraway, 2009). Na posição-sujeito corpo (inter)face há uma identificação com esses sentidos, sendo o corpo discursivizado como molde e suporte mecânico do objeto tecnológico.

Recorte 1

As tecnologias vestíveis ainda estão sendo moldadas, mas já representam um enorme potencial para o mercado [...] $(04 / 08 / 2013)^{44}$.

Nesse recorte podemos pontuar o processo de produção do objeto "tecnologias vestíveis" no campo do discurso, para além da mera descrição da criação de um produto. Do processo de produção desse discurso sobre as "tecnologias vestíveis", assinalamos que, embora essas tecnologias sejam acopladas ao corpo, o significante "corpo" não comparece nesse enunciado, nem em alguns outros que mencionam objetos tecnológicos na ordem de uma fusão com o corpo, o que nos leva a pensar sobre esse processo de produção de silenciamento. Dizemos silenciamento, pois, como vimos com Orlandi (2007a), este se diferencia do silêncio, que é inerente às palavras. O silenciamento é colocar em silêncio, seja pelo efeito constituivo de que dizer algo é silenciar algo, seja pelo efeito da proibição do dizer.

\footnotetext{
${ }^{44}$ Recuperado em 8 de setembro de 2013, de http://blogs.estadao.com.br/link/eletronicos-vestiveis-ja-saorealidade/
} 
Expliquemos, então, que, ao nosso ver, se trata de um silenciamento constitutivo, posto que os discursos ao se voltarem para os objetos tecnológicos, deles vão dizer, e portanto, deixarão de dizer diretamente do corpo. E pelo mesmo motivo, trata-se também de um silenciamento da ordem de uma certa censura, posto que no contexto sócio-histórico que habitamos, nos discursos que analisamos, o legitimado é dizer dos objetos tecnológicos, sendo o corpo tomado como um artefato, um manequim que dá suporte ao objeto tecnológico. Ou melhor, um corpo que opera como interface do objeto tecnológico.

Se por um lado o corpo é colocado em silêncio, por outro lado, apontamos que no silêncio inerente às palavras, o corpo pulsa nas palavras "vestíveis" e "moldadas", já que é o corpo quem veste as tecnologias e é do corpo que se tira as medidas para moldar as tecnologias. Assinalemos, ainda, que não é o corpo como um conjunto que serve de molde, mas sim, parte, como a face, no caso das "tecnologias vestíveis" que analisamos nessa seção. Assim, legitimase um corpo interface que comparece na moldagem como "face".

Anunciamos assim, mudanças no processo de produção dos objetos tecnológicos de conexão à rede eletrônica que antes eram moldados tendo em vista interfaces como os mouses, os teclados, as caixas de som, as telas, com os quais o sujeito interage. Como apontou Cebrián (1999), interfaces maquínicas estão sendo destituídas, e, acrescentamos que o corpo tem sido convocado à interface como nas telas touch, as quais têm dispensado mouses pelo contato direto dos dedos, e mais atualmente, os dedos também têm sido destituídos, como vimos na seção 2.2.2, ao passo que a face e os olhos são convocados a ser interface dos objetos tecnológicos, cada vez mais portáteis, leves e acoplados ao corpo.

Se anunciamos mudanças nos processos de produção dos objetos tecnológicos, fundamentamos essas mudanças nos enunciados que circulam em dados contextos sóciohistóricos, as quais, como apontou Payer (2005), produzem uma dada forma de sujeito e acrescentamos, uma dada forma de objeto. Tais enunciados são sustentados pelo poder do Mercado (Payer, 2005) que tem capturado o sujeito na busca de um corpo semanticamente potente na relação com o objeto tecnológico de conexão à rede eletrônica. Desde a década de 40 do século passado, como vimos no capítulo 2, apontamos o quanto o objeto tecnológico foi modificado, miniaturizado, acompanhado de dizeres de potência, que passaram a reverberar na Cibercultura, e os quais o Mercado legitimou. Na miniaturização dos objetos tecnológicos, a ênfase na produção destes é tamanha que se deixa de dizer do corpo, das reais aplicações desses objetos tecnológicos no corpo, para o corpo. Ou seja, outros sentidos também são silenciados, além do próprio corpo. 
Assim, nesse recorte, vemos reverberar que "As tecnologias vestíveis ainda estão sendo moldadas, mas já representam um enorme potencial para o mercado". O “mercado" é visado e, podemos dizer que nos poros desse significante, também ressoa o corpo, já que o mercado é composto pelo corpo de consumidores, por corpos consumidores. Então, se as tecnologias vestíveis são moldadas ao corpo, podemos dizer que elas também são moldadas para o corpo consumidor, pelo efeito de sentidos de que "representam um enorme potencial para o mercado", estando suposto, então, que há corpos para consumir essas tecnologias.

Salientamos que essa suposição é alocada nos significantes "ainda" e "mas já". O primeiro marca um intervalo entre a oferta do produto e a criação da demanda efetiva (posto que o que existe é a demanda do Mercado por objetos cada vez menores e mais potentes para tentar fisgar o sujeito a produzir demandas), já que essas tecnologias estão em fase de adaptação e criação, ou seja, não estão tão disponíveis aos corpos consumidores. Ou seja, nem muitos corpos usam esses objetos nem eles estão nas vitrines ${ }^{45}$. É um tempo que não adveio mas é suposto à advir. E o "mas já” opera em um tempo à advir, mas que é colocado como que já adveio, como se a demanda dos corpos consumidores já existisse e sustentasse "um enorme potencial para o mercado".

Em “enorme potencial" vemos reverberar sentidos do que Payer (2005) aponta sobre o poder do Mercado e seus enunciados vinculados ao "sucesso" e que fisgam o sujeito na busca pela completude, pela potência, pelo sucesso. A partir desse gesto de interpretação, assinalamos que comparece no discurso a posição-sujeito corpo(inter)face, posição que se identifica a formação discursiva do Mercado e responde à forma-sujeito do mercado de modo a fazer reverberar os sentidos sobre esses objetos tecnológicos de conexão à rede eletrônica, afetado pelo "potencial” que, se destinado ao mercado, também o é para o corpo. Faz naturalizar sentidos de que a identificação a forma-sujeito do mercado é transparente, silenciando qualquer outra modalidade, como a contra-identificação e a desidentificação. Assim como faz reverberar sentidos de um corpo silenciado em pról da tagarelice sobre os objetos tecnológicos.

Recorte 2

O anúncio oficial do invento, que mostra fotos da lente na mão de um cientista ou nos olhos de um coelho no laboratório, cita como exemplos básicos do que

\footnotetext{
${ }^{45}$ No Brasil, os óculos que conectam a rede eletrônica foram disponibilizados para testes para não mais que cinco consumidores experimentadores, aprovados pela Google. Havia expectativas de serem colocados no mercado em 2014, mas não o foram. Nos Estados Unidos são vendidas algumas unidades testes. São de uso exclusivo, como dissemos de experimentadores eleitos pela Google. As lentes de contato estão sendo alvo de diversos experimentos. "Mas - essas tecnologias - já" são fortemente noticiadas na rede eletrônica e em feiras de divulgação. Outras tecnologias vestíveis como relógios que conectam a rede eletrônica estão nas vitrines.
} 
seria possível os personagens Exterminador do Futuro e A Mulher Biônica. $(18 / 02 / 2008)^{46}$.

Do processo de produção dos sentidos que são legitimados nesse recorte, destacamos como o poder do Mercado se alia ao campo da ciência e também ao campo da ficção científica para dizer dos objetos tecnológicos e dizer dos exemplos do que é possível no acoplamento deles no corpo. Inferimos, assim, que o significante "anúncio oficial" faz presentificar o campo do Mercado trabalhando na oferta de um produto, um "invento" que é a lente de contato que conecta a rede eletrônica e propicia a realidade aumentada. Tal "anúncio" não se apóia em fotos quaisquer da lente. Apóia-se em fotos do invento "na mão de um cientista", "nos olhos de um coelho de laboratório". Vale-se então, além da proximidade com o campo da ciência pois muitas vezes o mercado patrocina a pesquisa de objetos tecnológicos tendo inclusive seus próprios laboratórios e não apenas utilizando da produção das universidades, assim como se vale dos sentidos legitimados sobre a ciência como a fidedignidade, a confiabilidade. Apoia-se também no campo da ficção científica, o qual fisga sujeitos na ilusão da potência na relação corpomáquina, e cita ciborgues como exemplos: "os personagens Exterminador do Futuro e A Mulher Biônica". Desse modo, se apóia tanto no campo da veracidade legitimadora da ciência quanto no campo da ficção, que é dita cada vez mais próxima da realidade.

Assinalamos, assim, que o anúncio não se apóia em dizeres explícitos sobre o corpo, mas em dizeres sobre o ciborgue, estando o corpo mais uma vez silenciado ao passo que comparece potente nos sentidos legitimados na ficção científica. Em se tratando de um invento como a lente de contato, que se acopla a superfície dos olhos, podemos rememorar que no filme e na série citados, o olho é um dos órgãos aprimorados com tecnologias que propiciam visão potencializada.

Nesse recorte enfatizamos que a posição que o sujeito ocupa no discurso ao abordar esse "invento" se enlaça a formação discursiva do mercado fazendo reverberar o "anúncio" de modo transparente, como se a relação sujeito, corpo e objetos tecnológicos só pudessem se dar da forma como o poder do Mercado as oferta. Como se o corpo, ou melhor, o olho, ao ser interface da lente acoplada em sua órbita pudesse enxergar como a ficção científica propõe, desconsiderando que, ainda que muitas imagens estejam dispostas na frente do olho, ele não pode tudo captar por sua própria constituição. Quando se olha para o alto, não é possível ver com clareza o que está no baixo, do mesmo modo quando se olha para direita e esquerda. É

\footnotetext{
${ }^{46}$ Recuperado em 10 de outubro de 2012, de http://tecnologia.terra.com.br/noticias/0,,OI2246293-EI12882,00Estudo+desenvolve+lente+de+contato+que+acessa+web.html
} 
interessante apontar como esse dado, que é científico, é silenciado quando se oferta objetos tecnológicos. Desse modo, ressaltamos que o Mercado seleciona de ambos os campos, científico e da ficção, os sentidos que lhe convém.

Por sua via, o sujeito, atravessado pela ideologia dominante, faz reverberar esses sentidos, alçando do interdiscurso os discursos que estão disponíveis pela formação discursiva dominante. Coloca-se em posição em que o corpo/olho, interface do objeto tecnológico, é silenciado ao passo que o ciborgue é referido por intermédio dos personagens. O sujeito, então, ocupa uma posição que faz reverberar o "anúncio" tal como é produzido, de modo que a repetição faz vigorar uma regularização na memória (Pêcheux, 1999), que vai atravessando o dizer de sujeitos. Como se só se pudesse dizer desse modo do corpo na relação com os objetos tecnológicos de conexão à rede eletrônica.

\begin{abstract}
Recorte 3
A visão dos super-heróis dos filmes de ficção científica é uma realidade mais próxima depois que uma equipe de cientistas conseguiu criar lentes de contato nas quais é possível projetar imagens por uma espécie de tela [...]

Por enquanto o dispositivo só possui um pixel, mas seus criadores o veem como um passo para a produção de lentes com vários pixels que permitam ver informação - como mensagens de e-mail - em tempo real sem ter uma tela diante da pessoa. $(23 / 11 / 2011)^{47}$.
\end{abstract}

$\mathrm{Na}$ esteira do recorte 2, o presente recorte também alça do interdiscurso, dos já-ditos disponíveis, a evocação da ficção científica ao se remeter aos "super-heróis dos filmes de ficção científica" e a evocação da ciência quando aponta "que uma equipe de cientistas conseguiu criar lentes de contato [...]". Assim, apontamos a repetição e a regularização da memória (Pêcheux, 1999) reverberando nos discursos dos sujeitos, ao passo que há o semblante de um acontecimento discursivo (Pêcheux, 2008), que não opera, posto que se há uma certa novidade em termos de "uma realidade mais próxima" que sai da ficção e pretende ganhar o cotidiano, com um novo objeto tecnológico que é produzido pela ciência e alavancado pelo Mercado, esse deslocamento não é acompanhado por discursos novos, ou seja, por uma atualização dos discursos e dos sentidos tanto sobre o objeto quanto sobre sujeito e corpo. A memória repetitória sustenta os dizeres, o sujeito se posiciona de modo a reverberá-los, identificando-se com a forma-sujeito do Mercado, e anuncia o repetitório com semblante de novidade. Desse modo, é legitimado o modo de dizer do corpo, quando convocado a lidar com objetos tecnológicos que cada vez mais a ele se acoplam, como ciborgue, fechando-se outros sentidos possíveis.

\footnotetext{
${ }^{47}$ Recuperado em 12 de setembro de 2012, de http://blogs.estadao.com.br/link/computadores-nas-lentes-decontato/
} 
Como podemos escutar nesse recorte, os sentidos sobre a "visão" possibilitada por essas lentes de contato que é a realidade aumentada, ou seja, a sobreposição de imagens virtuais provenientes do objeto tecnológico e da rede eletrônica à "realidade", são lançados à ficção. Podemos pensar que isso decorre em função de ser a memória (Pêcheux, 1999) a que o sujeito tem acesso para nomear essa forma de ver. Decorre da ficção fazer parte da fantasia humana de encontrar um objeto que lhe dê potência (Freud, 1930/2010; Lacan, 1995). Decorre do sujeito entrar em contato com o impossível do corpo (Gallo e Romão, 2011) e tentar negá-lo. Decorre da ideologia que se enlaça a esses sentidos e enlaça sujeito e corpo a uma determinada posição no discurso.

Posição na qual, o sujeito, por exemplo, ao invés de se haver e tecer sentidos sobre a proximidade entre o objeto tecnológico, o olho e as imagens projetadas na retina, migra para o campo da fantasia para explicar que tal visão é da ordem da potência, dos "super-heróis", ciborgues, e não se implica em levantar questões sobre os efeitos dessa proximidade, sobre a aplicabilidade dessa junção corpo e objeto. Assinalamos que os efeitos produzidos na posiçãosujeito que nomeamos corpo (inter)face, sob a incidência da formação discursiva dominante que prevê o uso maciço desses objetos tecnológicos, silencia o olho, suas funções, a visão enquanto algo que não consegue captar o todo, ainda que este supostamente lhe seja apresentado.

Apontamos essas questões sobre o olho posto que, na interface com o objeto tecnológico, ele é suporte e é tela de projeção. Como dito na enunciação, "uma equipe de cientistas conseguiu criar lentes de contato nas quais é possível projetar imagens por uma espécie de tela". Tela que não é bem delineada nesse recorte, faltando elementos para compreendê-la. Posteriormente comparece o dizer "sem ter uma tela diante da pessoa". Contextualizando tal recorte, ele é dos mais antigos, e podemos dizer que faltavam elementos para se nomear essa relação com a tela enquanto materialidade física que desaparece e dá lugar para a tela virtual que comparece como imagem virtual junto às imagens da realidade, posto que a lente projeta diretamente no olho a "informação - como mensagens de e-mail - em tempo real".

Os sentidos da relação sujeito, corpo e objetos tecnológicos de conexão à rede eletrônica vão sendo naturalizados e ainda sim preservam-se no campo ficcional. Como disse Lemos (2010), a cibercultura tem o desejo de juntar corpo e máquina, e a esse desejo se alia ao poder do Mercado (Payer, 2005). Na posição discursiva que se apresenta, ao invés de se dizer do corpo, do olho, os sentidos se fecham no ciborgue, se reduzem a abordar as características das lentes, passando-se a descrevê-la: "Por enquanto o dispositivo só possui um pixel, mas seus 
criadores o vêem como um passo para a produção de lentes com vários pixels". Ao se silenciar o corpo, é o corpo dos objetos tecnológicos que fica em evidência.

É interessante salientar que ao se dizer dos objetos tecnológicos de conexão à rede eletrônica e a relação com o olho, não comparecem sentidos levantados na ciência de possíveis prejuízos ao olho. São sentidos que se fazem presente em pesquisas. Sobre esse silenciamento que apaga outras nuances da relação sujeito, corpo e objetos tecnológicos de conexão à rede eletrônica, temos a dizer que ele não é casual. Funciona a partir da ideologia. Amordaçado ideologicamente, ao sujeito cabe identificar-se à forma-sujeito do discurso e ocupar um lugar no discurso em que o corpo (inter)face é discursivizado como pedaço de corpo acoplado ao objeto, mas que pode ter a "visão dos super-heróis dos filmes de ficção científica", desavisados de que o olho nem tudo vê, ainda que mais e mais imagens sejam postadas diante dele (Lacan, 1998d).

\begin{abstract}
Recorte 4
O projeto se assemelha à história do curta-metragem futurístico Sight, que retrata um personagem que usa uma lente de contato inteligente do tipo. Tudo é feito através das lentes. Ao cortar um legume, a lente projeta o tamanho exato dos pedaços que ele precisa cortar. Ao sair para um encontro romântico, ele puxa dados de redes sociais sobre seu par. $(04 / 08 / 2013)^{48}$.
\end{abstract}

Esse recorte, ao fazer vigorar sentidos sobre os objetos tecnológicos de conexão à rede eletrônica, de modo mais específico sobre as lentes de contato que prometem a realidade aumentada, e ainda ao projeto destas lentes, se apóia no curta-metragem "Sight"49 estabelecendo semelhança entre "o projeto" e o conteúdo do curta. Salientamos, de início, que do curta-metragem, a presente formulação recorta os efeitos de inteireza como: "Tudo é feito através das lentes", "a lente projeta o tamanho exato dos pedaços que ele precisa cortar", "puxa os dados de redes sociais sobre seu par", produzindo sentidos de exatidão, veracidade, de "tudo" poder fazer por meio dos objetos tecnológicos, na rede eletrônica, nas redes sociais, sobretudo a partir da realidade aumentada, que dispensa uma tela física, ao passo que o objeto tecnológico se acopla na superfície do olho.

No recorte e no curta-metragem, as atividades mais corriqueiras do dia a dia como cortar legume passam pelo crivo das lentes que desenham sobre o objeto a medida exata. Puxar os dados do par nas redes sociais é embebido em sentidos de que nestas redes estão contidos os

\footnotetext{
${ }^{48}$ Recuperado em 10 de setembro de 2013, de http://blogs.estadao.com.br/link/eletronicos-vestiveis-ja-saorealidade/

${ }^{49}$ Recuperado em 30 de agosto de 2014, de https://www.youtube.com/watch?v=8eqPiHwqGpM
} 
dados de cada um simulando uma equivalência entre o "Eu sou" da rede com o "Eu sou" fora da rede, simulando a transparência das palavras, do sujeito, ainda que, por exemplo, a modalidade "face”(book)/Facebook já indicie por si só tratar-se de um perfil, uma faceta, um modo de se apresentar ao outro/Outro/Sujeito que passa pelas relações imaginárias e ideológicas do que é estar na rede. Um perfil que pode ser bem diferente da vida que se vive no dia a dia, na qual o sujeito é convocado a lidar com os furos, com os furos do "Eu sou" (Pêcheux, 2009a). Perfil-ficção que, como vimos com o recorte que analisamos na seção 2.2, pode produzir na rede uma vida supostamente feliz (ou não), intensamente "curtida" pelos amigos da rede social.

Torna-se importante apontar que o curta-metragem não aborda só a faceta dos sentidos de exatidão e de veracidade contidos na rede eletrônica, sentidos de que acessar dados na rede seja uma garantia de êxito. Ao contrário, aponta os impasses dos sujeitos, os desencontros, ainda que se alie a sentidos que fazem valer as artimanhas proporcionadas por essas lentes de contato. Tais sentidos foram colocados em silêncio no recorte, e aí apontamos um efeito da ideologia do Mercado, produzindo o unívoco, um modo de dizer sobre o objeto tecnológico, sobre o corpo, que apaga outros sentidos e que faz reverberar um "corpo semanticamente normatizado" (Pêcheux, 2008) na relação com os objetos que o circundam, com efeitos de homogeneidade.

Assinalamos que acreditar que tudo está na rede e que o objeto tecnológico tudo possibilita é equivocar-se com a intereza, com a completude, com a fusão corpo-máquina. $\mathrm{O}$ corpo, como afirmou Sternick (2010) passa a ser deserto de gozo, um corpo mortificado, e, portanto, um corpo que cada vez menos se vê diante do improviso, de formas para lidar com o furo. Na posição-sujeito que aqui comparece podemos ver reverberar sentidos de potência do corpo ao usar a lente de contato denominada "inteligente", mais precisamente, potência do olho, criando efeitos de que tudo está sob controle. Nesse efeito, o sujeito comparece identificado a forma-sujeito do mercado que delineia esse modo de dizer do corpo. Um corpo que já é partido pela própria inscrição do objeto tecnológico em uma parte do corpo: na face, no olho, mas que se fixa nos sentidos de inteireza.

Assim, ao dizer do "projeto", o sujeito naturaliza sentidos de um corpo potente, se usar o objeto, trazendo nos poros dos sentidos a ebulição de que a fusão com o objeto tecnológico resulta na produção de um sujeito (com seu corpo) que crê na sua autonomia na relação com os objetos tecnológicos e não se dá conta de ocupar a posição de um autômato ao reproduzir o que está pré-estabelecido. Destacamos que no curta-metragem ressoam sentidos de naturalização do objeto acoplado ao olho, fazendo "Um" (Lacan, 1992), fazendo-se presente no cotidiano, criando ares de um sujeito livre ao acesso a realidade virtual e aumentada, enquanto está 
submetido ao que a rede de memória metálica (Orlandi, 2007b) e o Arquivo (Romão, 2012) lhe permitem. Trazemos estes sentidos sobre o corpo que ecoam do recorte e também do curtametragem, e dizemos "ecoam" porque eles não foram deliberadamente ditos. Podemos deles dizer a partir do que foi dito e do que foi silenciado, no caso, o corpo.

\begin{abstract}
Recorte 5
Ainda paira uma certa sensação de incredulidade, em que mais uma vez a indústria tecnológica tenta nos vender algo de que não precisamos. É cedo para ter certeza. Basta pensar que há uns dez anos você certamente teria dito que conseguiria viver tranquilamente sem um telefone que manda e-mails. $\mathrm{Ou}$ que um site onde todos os seus amigos passam o dia mostrando fotos da família ou compartilhando links pareceria algo bem supérfluo. $(31 / 03 / 2014)^{50}$.
\end{abstract}

Nesse recorte apontamos que o sujeito inicialmente se posiciona no discurso de modo a problematizar a identificação com a formação discursiva do mercado, marcando "certa sensação de incredulidade", que coloca em cheque o repetitório movimento da "indústria tecnológica" ao tentar vender "algo de que não precisamos". O repetitório é assinalado em "mais uma vez", e marca um movimento constante da indústria ao apresentar novos gadgets, apontando a proliferação das latusas, como disse Lacan (1992), objetos emaranhados em enunciados do Mercado (Payer, 2005) que sustentam a potência dos "novos" e a obsolescência dos "velhos" (Braunstein, 2010), que os apresentam como necessários e indispensáveis (a não ser que um novo seja colocado nas vitrines). Assinalamos, então, uma posição-sujeito que não se contraidentifica à forma-sujeito do mercado, mas também não a toma como inquestionável. Porém, está às voltas com a identificação, produzindo uma suspensão, mas, ao mesmo tempo a possibilidade de deslizar para a identificação, já que "Ainda paira" e "É cedo para ter certeza", indiciam que o sujeito está nas bordas indentificatórias.

Podemos acompanhar seus passos para a identificação ao passar a justificar que o objeto tecnológico e a rede eletrônica são precisos, alçando elementos de uma memória, legitimada, que sustenta que o objeto é preciso. Faz relação entre um momento ("há uns dez anos") em que um "telefone que manda e-mails" ou "um site onde todos os seus amigos passam o dia mostrando fotos da família ou compartilhando links" poderiam não ser tão necessários, soando como supérfluos, ao passo que sustenta, ao dobrarmos o discurso, que hoje não se vive tranquilamente sem esse telefone e sem essa rede social, e quiçá não se viverá sem os objetos tecnológicos de conexão à rede eletrônica que ora se apresentam e trazem a realidade

\footnotetext{
${ }^{50}$ Recuperado em 1 de abril de 2014, de http://blogs.estadao.com.br/homem-objeto/a-tecnologia-vestivel-podefazer-o-celular-virar-peca-de-museu/
} 
aumentada. Assim, podemos ler que o sujeito se lança em uma posição no discurso que naturaliza sentidos sobre a necessidade de objetos tecnológicos e rede eletrônica, ao passo que aposta na naturalização do acoplamento com o corpo e partes do corpo, da realidade aumentada, da rede eletrônica acessível e acessável incessantemente (Gallo \& Romão, 2011). Embora o sujeito não aborde o corpo, é disso que se trata ao naturalizar os objetos tecnológicos vestíveis. Podemos associar esses sentidos à Figura 4 na qual analisamos uma materialidade discursiva que indiciava a necessidade de internet como algo da ordem do orgânico, tal como o ar, a água, a comida. Desse modo, os sentidos sobre necessidade se encontram e mantém discursos de que o objeto tecnológico e a internet são vitais, de que não se consegue viver tranquilamente sem este.

Com esse gesto de interpretação, pudemos acompanhar a movência do sujeito no discurso, sendo fisgado pelos efeitos de naturalização dos enunciados do Mercado, que ofertam "mais uma vez" objetos, e "mais uma vez" criam demandas, produzindo efeitos de que há desejo pelo(s) objeto(s), há corpos (inter)face, que são interpelados de modo a não achar mais supérfulo ou estranhar o fato de se passar o dia mostrando fotos nas redes sociais. Reiteramos nossos apontamentos ao longo dos capítulos teóricos do quanto a formação discursiva do Mercado se alia a mostração da sociedade do espetáculo (Debord, 2003), a visibilidade que cada vez mais busca o olho, como interface. É o olho que olha a rede eletrônica, a rede social, é o olho que se acopla ao objeto tecnológico. "Mais uma vez" insistimos em apontar os sentidos legitimados, estabilizados e apontamos que o contexto sócio-histórico sustenta dizeres, via memória, fazendo com que algo que pode permanecer sendo supérfluo, ao menos para alguns sujeitos, seja legitimado como necessário.

Ao passo que dizer dos objetos tecnológicos de conexão à rede eletrônica e, mais precisamente sobre os vestíveis, implica em não abordar o corpo em alguns discursos, como os que trouxemos, e como esse que analisamos, apontamos o retrato de um corpo silente diante do objeto tecnológico. Um corpo inerte, que aciona o objeto tecnológico com movimentos suaves, e a promessa de uma potência à vista. Uma promessa de que algo será encontrado, a plenitude de um corpo deserto de gozo? Uma promessa a ser cumprida com o próximo objeto tecnológico, com o próximo objeto tecnológico, com o próximo... 


\subsection{Entrada discursiva 2: Sentidos de invocação de partes do corpo para o acoplamento e destituição de outras partes}

No processo de produção de sentidos sobre a relação sujeito, corpo e objetos tecnológicos de conexão à rede eletrônica, encontramos sentidos de invocação de partes do corpo para o acoplamento com o objeto, mais precisamente como "corpo-face". Ou seja, a face e os olhos sendo convocados a ser interface e, também, sendo convocados a um modo de usar o objeto tecnológico, o mode d'emploi apontado por Braunstein (2010). Se por um lado, partes do corpo são convocadas, outras são destituídas no discurso, e, levantamos questão sobre esse ponto. Pois, por que ao elencar partes do corpo para o objeto tecnológico ser acoplado, é preciso dizer que outras partes não são necessárias e, ademais, imbuí-las de sentidos de despotencialização? Apontamos, então, que, no modo de usar o objeto tecnológico ressoa a formação discursiva do mercado que oferta o objeto tecnológico aos sujeitos consumidores, imbuídos em sentidos de potência ao corpo, e, à medida que destituem interfaces como mouses, teclados, também destituem as mãos e outras partes do corpo, despotencializando-as, porque discursivamente serão potencializadas outras, em um outro objeto que, se não for supostamente mais potente, não enlaçará sujeitos-consumidores no contexto sócio-histórico no qual esses sentidos são legitimados. A ideologia sustenta, via dissimulação do assujeitamento, que haverá sempre um produto mais potente e tem enlaçado sujeitos ávidos que se identificam à formasujeito do mercado e se lançam a buscar potência, e um corpo que cada vez menos se move ao comparecer como interface do objeto.

Nesse jogo de invocação de partes do corpo e destituição de outras partes, escutamos ressoar aspectos da fragmentação do corpo e da imagem totalizante do corpo que atravessam o sujeito na constituição do eu, segundo Lacan (1998c) e Soler (2001), e reverberam durante a vida. Ao passo que a ideologia incide em sentidos de invocação e destituição, há um corpo que é fragmentado no discurso. Por outro lado, é ofertado um corpo potente no acoplamento com o objeto que permite a conexão à rede eletrônica e à realidade aumentada, podendo ser cada vez mais inerte na realidade e mais movente na rede eletrônica. Há então, um ideal de sujeito, um ideal de corpo, que nos faz associar com o júbilo do sujeito diante da imagem especular, acreditando numa imagem totalizadora. Imagem totalizadora importante porque oferece contorno ao eu, porém pode ser tomada como ideal, na medida em que tampona a falta. E sustentada como ideal pela formação discursiva do mercado. 
Salientamos, então, que o modo de dizer do uso do objeto tecnológico, associado a invocação e destituição de partes do corpo, fisga o sujeito em algo da constituição do eu, no campo do recalque do inconsciente, e é enlaçado a interpelação ideológica do mercado que determina um modo de dizer que faz reverberar a potência do corpo, via partes, como horizonte. É interessante apontar que é uma partição do corpo que intenta tamponar a falta e fazê-la comparecer somente na instituição de um outro objeto tecnológico, no discurso mercadológico. Apontamos também que, em cada contexto sócio-histórico, circulam modos de dizer sobre o corpo, e com Mauss (1974), Courtine, Corbin e Vigarello (2008), Azevedo (2013), Pêcheux (2009a, 2008) e Orlandi (2012b, 2014, 2015), podemos apontar como os gestos são fabricados, assim como os objetos tecnológicos.

No modo de dizer sobre o corpo, interface do objeto tecnológico, veremos que comparecem sentidos de que o corpo envia "comandos", ao passo que o objeto "permite" ações, criando ares de autonomia, enquanto corpo e objetos estão submetidos a formação discursiva do mercado, ao modo de um manual do usuário, ou melhor, um visual do usuário, já que é legitimado que as mãos são desnecessárias e incômodas na relação com o objeto. Se nos recortes anteriores, o corpo é silenciado em detrimento a sentidos sobre ciborgues, nos recortes seguintes, o corpo comparece, fragmentado, no discurso.

\begin{abstract}
Recorte 1
Há algo a ser dito em favor dos aparelhos vestíveis: eles resolvem um dos grandes incômodos dos smartphones, que é precisar das mãos para usá-los. Com um óculos ou relógio conectado, acabaram-se os desajeitados momentos de se buscar um celular no fundo da bolsa ou no chão do carro. Não é preciso, aliás, parar o carro para usar, nem desviar o olhar do volante.

Olhando pelo ângulo da praticidade, os vestíveis fazem tanto sentido que sua adoção em massa será apenas questão de tempo e custo. Espere até 2030. Seremos lembrados como uma era rudimentar de aparelhos móveis, ilustrada por pitorescas cenas onde as pessoas telefonavam com as mãos. $(31 / 03 / 2014)^{51}$.
\end{abstract}

Por meio desse recorte, podemos apontar com Mauss (1974) o quanto os gestos humanos são fabricados pelas normas; com Pêcheux (2009a), como o sujeito é atravessado pela ideologia que determina o que pode e deve ser dito/feito em dado contexto sócio-histórico; e com Orlandi (2012b) como a ideologia produz um corpo de discurso. Também podemos apontar que no capítulo 2 traçamos de certo modo, a indicação de que, ao passo que os objetos tecnológicos são miniaturizados para se acoplarem ao corpo, vão destituindo interfaces

\footnotetext{
${ }^{51}$ Recuperado em 1 de abril de 2014, de http://blogs.estadao.com.br/homem-objeto/a-tecnologia-vestivel-podefazer-o-celular-virar-peca-de-museu/
} 
maquínicas e também interfaces corpóreas. Apontamos então, aqui, as normas, a ideologia, sustentando a destituição tanto maquínica quanto corpórea e a legitimação de partes do corpo para fazer interface com o objeto tecnológico.

Pautadas no que dissemos, salientamos que há uma tomada de posição do sujeito nesse recorte nomeada como "em favor dos aparelhos vestíveis", que, se se acredita autônomo em seu dizer, reproduz enunciados do Mercado que legitimam a proliferação de objetos tecnológicos e seus modos de emprego, e elegem partes do corpo para interfacear o objeto, criando ares de um sujeito livre, ao passo que é submetido ao manual/visual do usuário. Há um modo de operar com o objeto tecnológico que não é feito de qualquer modo. Assim, sentidos de liberdade como "acabaram-se os desajeitados momentos de se buscar um celular no fundo da bolsa ou no chão do carro. Não é preciso, aliás, parar o carro para usar, nem desviar o olhar do volante" são ventilados, de modo que o sujeito não se dê conta de seu assujeitamento ao objeto tecnológico, ou melhor, seu assujeitamento aos discursos que sustentam o objeto e o legitimam.

Como já apontamos anteriormente, com a invenção das telas touch, os mouses foram destituídos e as mãos/dedos foram instituídos como interface do objeto. Com a invenção dos “aparelhos vestíveis", as telas touch têm sido destituídas, ao passo que as mãos/dedos também. De modo que o que ontem era legitimado, hoje não é mais. É assim que, nesse recorte, se legitima que "precisar das mãos" torna-se "um dos grandes incômodos dos smartphones" de modo que o sujeito toma posição identificando-se com a forma-sujeito do mercado "em favor dos vestíveis" e coloca em questão "as mãos", fazendo reverberar que "acabaram-se os desajeitados momentos de se buscar um celular no fundo da bolsa ou chão do carro"ou que não é preciso parar o carro para usar o smartphone. Via identificação, o sujeito faz circular sentidos de que "com um óculos", as mãos podem ser destituídas, assim como os smartphones. Desse modo, os movimentos mais intensos com as mãos podem ser substituídos por movimentos mais sutis como a movimentação do olho, comando de voz, leves toques na haste dos óculos, ou em versões mais recentes, apenas com a movimentação dos olhos.

Assinalamos, assim, que o sujeito enquanto se inscreve em uma posição discursiva na qual o corpo comparece como (inter)face, naturaliza sentidos de um corpo que pode atender telefonemas, acessar a rede eletrônica por meio da realidade aumentada, um corpo autônomo, na destituição de suas partes e na eleição de outras para fazer interface. Um "corpo-face" naturalizado em seus movimentos mais sutis, destituído de membros, no discurso. Um corpo cada vez mais inerte, embora com ares de tudo poder fazer na interação com o objeto 
tecnológico. Como se seus olhos pudessem captar com precisão as imagens virtuais e as da "realidade", sem riscos, sem precisar "parar o carro para usar, nem desviar o olhar do volante".

Apontamos ainda que, se o sujeito toma posição "em favor dos aparelhos vestíveis", assujeitado, também demarca que é uma posição que olha "pelo ângulo da praticidade", deixando, portanto, outros ângulos silenciados. Do "ângulo" que evoca, o sujeito discursivo toma posição ${ }^{52}$ pela identificação à forma-sujeito do mercado e aponta a "adoção em massa" como questão de "tempo e custo", sem levantar, por exemplo, alguma questão em relação a contra-identificação a esses "aparelhos", contra-identificação à forma-sujeito do mercado. Seguindo na posição no discurso identificada ao Mercado, se vale novamente dos sentidos de obsolescência (Braunstein, 2010) tanto dos “aparelhos móveis" quanto das “mãos”, apontando as condições de produção atuais, como uma "era rudimentar" a partir do ângulo pelo qual olha o futuro (o presente e o passado).

Assim, o sujeito não se apercebe que reproduz os mesmos discursos posto que se enlaça na destituição e na instituição de objetos e de partes do corpo, dizer repetitivo que ao se supor inovador elegendo uma nova parte do corpo, não se dá conta de que institui o que será destituído. Nesse discurso, podemos ainda pontuar que a legitimação de um corpo que precisa só de algumas partes para se mover incessantemente na rede eletrônica, ao passo que permanece estático, fazendo movimentos sutis com os olhos, remete-se a dizeres de fragmentação do corpo, o que faz associar com a movimentação psíquica do sujeito entre a fragmentação de um corpo e um corpo suposto total, na relação especular (Lacan, 1998c). Preso na fragmentação e na imagem suposta totalizante, o sujeito é capturado no discurso do mercado (Braunstein, 2010) que lhe oferta um objeto suposto suprir desejo, e que é colocado ainda no campo da necessidade. Um objeto que toma uma forma e outra forma e outra forma, sob a incidência do poder do Mercado (Payer, 2005), sendo que o objeto, aquele que supostamente suprirá o sujeito, é inexistente (Lacan, 1995). Resta um sujeito que se lança a um ideal inatingível.

\section{Recorte 2}

[...] o Google Glass permite que os usuários utilizem diversos recursos através de comandos de voz e sensores de movimento, podendo conectar-se com smartphones para receber e enviar mensagens e chamadas de ligações e videoconferência. $(03 / 02 / 2014)^{53}$.

\footnotetext{
${ }^{52}$ Lembrando que tomar posição inclui o assujeitamento.

${ }^{53}$ Recuperado em 05 de fevereiro de 2014, de http://www.techtudo.com.br/noticias/noticia/2014/02/ja-e-possivelcomprar-o-google-glass-veja-restricoes-dos-oculos-inteligentes.html
} 
No presente recorte, comparecem modos de dizer sobre o corpo na relação com o objeto tecnológico, no caso, os óculos que conectam a rede eletrônica. Modos de dizer que abarcam de um lado, o que objeto permite, e de outro, o que os usuários devem fazer com seu corpo para utilizá-lo. Assim, os usuários, aqueles que portam o objeto em sua face, ofertando-a como interface, para que utilizem os "diversos recursos" dos óculos, devem enviar "comandos de voz" e alguns "movimentos" específicos, os quais não são relatados nesse recorte. A partir desse modo de utilização do corpo, o objeto "permite que os usuários utilizem diversos recursos". Podemos pontuar, então, que há um jogo de forças entre o que o objeto permite e os comandos do usuário. Todavia, tudo se passa de modo transparente como se houvesse uma interação, enquanto que os comandos enviados pelos usuários não são quaisquer, são também determinados pelo objeto. Ou melhor, pelos discursos que os sustentam e que determinam quais partes do corpo são invocadas para fazer interface e o que as partes devem fazer.

Queremos dizer com isso que há uma captura do sujeito e do corpo com ares de liberdade, enquanto está assujeitado a formação discursiva que sustenta o lugar do objeto tecnológico como aquele que "permite". Se de fato permite algo, não permite que seja de qualquer modo, daí indicarmos mais uma vez o quanto as "normas sociais" (Mauss, 1974), que podemos associar à ideologia (Pêcheux, 2009a), atravessam a relação sujeito, corpo e objetos tecnológicos, no âmbito dos gestos, sem que os sujeitos disso se dêem conta. Além do mais, ressoa no "permite", sentidos de que o sujeito pode, autorizado pelo objeto. Sustentando essa relação de poder, está a formação discursiva do mercado que disponibiliza no interdiscurso estes sentidos que comparecem no intradiscurso, no recorte que estudamos.

Portanto, os usuários que se identificam a forma-sujeito do mercado inerente aos discursos que sustentam esse objeto tecnológico (e outros) são enlaçados em um campo de poder, no qual podem "conectar-se com smartphones para receber e enviar mensagens e chamadas de ligações e videoconferência", por meio dos comandos de voz e movimentos ao interfacear o objeto tecnológico. Assim, podem comandar outros objetos tecnológicos (como smartphones) e também comparecer com seu corpo virtualmente em videoconferências. Se Dias (2008) nos aponta o corpo comparecendo como grafia onde ele não pode comparecer fisicamente, com os novos objetos tecnológicos de conexão à rede eletrônica e à realidade aumentada, cada vez mais o corpo tem comparecido como imagem, sem utilizar os recursos da escrita, havendo um movimento tecnológico para que compareça de modo mais "real” possível, como vídeoconferência.

É importante dizer que as invenções tecnológicas, tal como Freud (1930/2010) apontou, são criações humanas, as quais respondem a um desejo de ir além do corpo. Portanto, é 
movimento criador e importante. Todavia, torna-se fundamental destacar o lugar discursivo que tem sido ofertado e legitimado para esses objetos. É um lugar como Braunstein (2010) apontou em que o objeto é tomado pela lógica dos mercados, também um discurso. Um discurso que visa a ofertar ao sujeito o objeto que suspostamente lhe completará, objeto supostamente poderoso, que, no entanto, se se prolifera em diversos, se apresentando cada vez mais potentes, logo em seguida são destituídos, e por esse movimento mesmo de instituição/destituição podemos dizer que há aí indícios de que há algo de inalcançável ao corpo, ao sujeito, ao discurso, ao objeto, ainda que a estabilidade esteja posta em um aparente controle, num modo de usar o objeto tecnológico, num modo legitimado de dizer sobre ele.

Assinalamos que há a possibilidade de se dizer de outro modo sobre esse movimento criador. As artes trabalham com o desejo de outro modo, com a produção de outro modo, lidando com o furo, com o não encontro do objeto. Apontamos, assim, que há modos de se dizer do corpo e que há regiões do interdiscurso que ofertam dizeres para cada modo de dizer. Aos sujeitos há assujeitamento, há identificação com forma-sujeito distintas e diversas. Todavia, a formação discursiva dominante, há que se reiterar que é mercadológica, e atravessa a qualquer sujeito, daí uma naturalização das práticas corporais na pós-modernidade atrelada às tecnologias como apontou Azevedo (2013a).

Nesse recorte, então, o sujeito ao abordar o objeto tecnológico é atravessado pelos efeitos de que o objeto "permite", enquanto que o que permite uma dada posição-sujeito é a formação discursiva do mercado, na qual o corpo comparece como interface multifacetada, na qual partes do corpo são convocadas, como a face e alguns poucos movimentos, ao passo que o corpo pode comparecer virtualmente por videoconferência, em uma outra modalidade de inscrição do corpo que vai na linha da corpografia: o corpo impossibilitado de comparecer fisicamente, comparece de outro modo. Entretanto, esse outro modo é tantas vezes discursivizado como se de fato o corpo lá estivesse, tomando a virtualidade como um ideal de corpo.

Recorte 3

O Google Glass ganhou um sistema de notificações muito mais intuitivo. Com o nome de Notification Glance, o recurso permite visualizar as notificações somente com uma movimentação dos olhos.

O método atual exige que o usuário dê um toque no touchpad ou balance a cabeça quando receber um alerta de notificação para poder vê-la. Com o novo recurso, ele precisará somente virar os olhos para a tela do óculos inteligente 
que ele identificará aquilo como um comando para exibir as notificações. $(05 / 06 / 2014)^{54}$.

Trabalhando a intertextualidade com o recorte 2, assinalamos que no recorte 3 também comparece o significante "permite", indiciando que há uma repetição que regulariza o campo de memória, que regulariza o jogo de forças dos dizeres disponíveis sobre dado assunto. Assim, vemos comparecer a formação discursiva do mercado que sustenta um modo de dizer do objeto e do corpo (inter)face que o usa, tendo, tanto o objeto quanto o corpo-sujeito lugares préestabelecidos no discurso. Via regularização, objeto e sujeito são discursivizados do mesmo modo, ainda que um "novo recurso" esteja sendo ofertado ao sujeito, recurso que cria ares de acontecimento, não discursivo, posto que não desloca sentidos.

O "novo recurso", apresentado como "um sistema de notificações muito mais intuitivo", o "Notification Glance", nos remete ao que Lemos (2010) aponta sobre a antropomorfização das máquinas, ou seja, a atribuição de características humanas aos objetos, no caso, sendo essa característica, a intuição, representada discursivamente como um "sistema" "intuitivo". Tal sistema capta a "movimentação dos olhos" e a identifica a "um comando". Salientamos que se trata de um recurso que se assemelha em termos funcionais às tecnologias touch que captam a movimentação dos dedos e que, embora o recurso se desloque para identificar a movimentação dos olhos, outra parte do corpo, não há alguma atualização em termos discursivos no qual incida uma mudança na posição discursiva. A atualização se refere à parte do corpo visada para interfacear a relação com o objeto tecnológico: os olhos, em detrimento de outras partes. Acresce-se a potência ao olho, como veremos nos recortes discursivos da Entrada Discursiva 3, do mesmo modo que aos dedos foram atribuídos poderes como analisamos no recorte abordado no capítulo 2 (Geração Touch), na qual compareceram as seguintes formulações: "O mundo na ponta dos dedos. Suas decisões nas pontas dos dedos. Dedos indicando [...]”.

Destacamos, de outro modo, que o corpo comparece cada vez mais estático diante do objeto tecnológico, ao passo que lhe é ofertada a possibilidade de interagir com o meio, como ressalta o recorte 1 da presente Entrada Discursiva, já que o usuário pode atender a um telefonema enquanto dirige ou acessar e-mails, enfim. Todavia, enfatizamos que, na relação com o objeto tecnológico vestível a busca é por um corpo estático, com movimentos sutis. Assim, entre o "método atual" que "exige que o usuário dê um toque no touchpad ou balance a cabeça quando receber um alerta de notificação para poder vê-la" e o "novo recurso", o que

\footnotetext{
${ }^{54}$ Recuperado em 06 de junho de 2014, de http://www.techtudo.com.br/noticias/noticia/2014/06/google-glassganha-sistema-de-notificacoes-somente-no-olhar.html>
} 
muda é que para "ver" é necessário apenas a movimentação dos olhos. Se podemos dizer que o "novo recurso" se associa à praticidade, apontada no recorte 2 da presente Entrada Discursiva, já que se o olho é o órgão que vê e ele é conclamado na realidade aumentada e na realidade virtual, é por meio dele que se acessa as "notificações", nada mais prático do que só requisitar esse órgão para a conexão com o objeto. Todavia, não podemos deixar de trazer sentidos silenciados à tona e que trabalham na regularização de que é assim e somente assim que se dá a relação sujeito, corpo e objetos tecnológicos na pós-modernidade.

Salientamos que a formação discursiva do mercado se alia a miniaturização, a instantaneidade do acesso a "notificações", ofertando um objeto potente e um corpo que tudo pode acessar com poucos movimentos. Ademais faz vigorar a visibilidade aclamada na sociedade do espetáculo (Debord, 2003), criando efeitos de que o sujeito tudo pode ver ao acoplar-se ao objeto tecnológico que só demanda que se tenha um olho, para ofertar um olho que tudo vê, e ofertá-lo a outros olhos, ávidos por olhar. Silencia, no entanto, que o olho nem tudo capta, que o olhar é da ordem da castração (Lacan, 1998d).

Advertidos de que o discurso do mercado (Braunstein, 2010) vai na contramão da castração, ofertando objetos que supram o sujeito (ao mesmo tempo em que criam uma nova demanda por um objeto mais potente), apontamos que ao sujeito nomear o "método atual" e o "novo recurso", instala dois modos de dizer do presente, no qual um já destitui o outro, e já destitui partes do corpo requisitadas na interface. Assim, afirmamos que o sujeito fisgado na posição discursiva que convoca o corpo a ser interface, se filia a discursos que sustentam o sonho da Cibercultura de antropomorfizar as máquinas (Lemos, 2010), sonho capturado pelo discurso do mercado e que faz reverberar a instituição e a destituição de partes do corpo e do objeto como se estivesse modificando a relação sujeito, corpo e objeto tecnológico, enquanto está apenas a ilustrando com um "novo recurso" que se vale da mesma forma de assujeitamento, via mercado.

Recorte 4

O físico teórico Michio Kaku [...] afirmou em entrevista que em menos de 30 anos qualquer pessoa será capaz de acessar a internet apenas com um piscar de olhos.

Kaku [...] declarou que essa tecnologia estará presente em lentes de contato e o portador poderá ativar a internet com uma simples piscada, recebendo as informações diretamente em sua lente [...]. $(30 / 11 / 2011)^{55}$.

\footnotetext{
${ }^{55}$ Recuperado em 23 de março de 2013, de http://www.tecmundo.com.br/ciencia/15995-fisico-renomado-revelacomo-sera-o-futuro.htm
} 
Se no recorte anterior, trabalhando a intertextualidade, recorremos ao sentido de praticidade evocado no recorte 1 no que tange aos dizeres sobre a relação sujeito, corpo e objetos tecnológicos de conexão à rede eletrônica, no presente recorte podemos ver outro sentido sustentando essa relação que é o sentido de capacidade. Isso ressoa em "qualquer pessoa será capaz de acessar a internet apenas com um piscar de olhos". Porém, tal sentido já ecoava no anterior, posto que já anunciava que o usuário "precisará somente virar os olhos para a tela". Em nosso gesto de interpretação anterior, apontamos o fato de ser necessário apenas o olho para interfacear o objeto, o que comparece discursivamente nesse recorte como sendo necessário “apenas um piscar de olhos". Se o recorte anterior se refere ao objeto óculos, o presente recorte se refere ao objeto lente, e assinalamos que, em ambos, figura a ideia de um corpo "capaz de acessar a internet com um piscar de olhos".

Tal sentido remete a um modo fácil de lidar com o objeto, representada em "simples piscada", indiciando um modo de uso acessível a "qualquer pessoa", que tenha olho. Assim, o objeto tecnológico vestível, ao contrário, por exemplo, do primeiro computador, o Eniac, é portátil e é acoplado diretamente no olho-interface, tornando difícil saber se o olho porta ou não o objeto. Assim, cria um semblante de que o corpo não tem o objeto e nem o objeto existe, porque é imperceptível, todavia, coloca o portador em condições de poder "ativar a internet com uma simples piscada, recebendo as informações diretamente em sua lente" fazendo existir o objeto que completaria o sujeito.

O sujeito nesse discurso ventila sentidos advindos de um outro, o físico (Kaku), e os repete, de modo que a relação corpo e objeto tecnológico se dê de modo transparente, bastando a instantaneidade de um piscar de olhos para que o sujeito se movimente na internet, como se só bastasse essa capacidade para regular essa relação, silenciando aqueles que não se identificam com as lentes ou ainda aqueles que não podem se enlaçar ao Mercado pela via financeira. Essa relação de poder e simplicidade é reverberada sem se levantar questões sobre a complexidade de se ter um objeto como esse no olho, já que ao olho cabiam apenas objetos que corrigissem sua falta a ver, de um modo faltante, como Freud (1930/2010) apontou em relação aos óculos de grau.

A formação discursiva do mercado reverberando, no caso do presente recorte, no discurso de um sujeito-físico e de um sujeito que se dispõe a apresentar o produto aos corpos potencialmente consumidores, trabalha para a identificação ao poder do Mercado (Payer, 2005) ao mesmo tempo em que cria ares de liberdade, imbuídos de praticidade, à medida em que o corpo/olho comparece como interface. 


\section{Recorte 5}

[...] A sensação de vestir o Google Glass pela primeira vez é estranha. Acostumados a usar as mãos para comandar eletrônicos, há uma impressão de não saber o que fazer com o dispositivo. [...] a falta de costume faz você manter a cabeça estática. Para quem olha de fora, imagino que seja igualmente estranho.

[...] Depois de alguns minutos, era como se eu tivesse o acessório há tempos. O caráter intuitivo do dispositivo é, sem dúvida, um de seus pontos fortes.

Os óculos [...] contam com um dispositivo um pouco acima do campo de visão que projeta imagens no olho.

A mudança de ponto de vista é surpreendente. Acostumados a olhar para baixo para buscar informações, o Google Glass permite interagir mais com o meio ao redor. Nada mais escapa aos olhos - e às lentes. Com conexão à internet, o dispositivo acessa conteúdo online por comando de voz ou com poucos toques em uma área sensível na lateral direita.

[...] é possível, com poucos comandos, acessar e-mails, mapas e páginas de busca, além de tirar fotos e gravar vídeos em alta resolução (720p) que podem ser compartilhados nas redes sociais.

Para acionar as funções dos óculos, antes é preciso falar "Ok, Glass". Em seguida, o usuário diz o quer fazer (em inglês) [...]. Isto divide opiniões. Conversar com um par de óculos em público é uma situação, no mínimo, desconfortável.

O som do Google Glass é uma evolução à parte. Sem alto-falante ou entrada para fone de ouvido, o som é projetado por vibrações no crânio de um tipo de botão em uma das pernas dos óculos, posicionado logo atrás da orelha. Com este sistema, somente quem está usando os óculos ouve o áudio de conversas telefônicas ou vídeos. $(04 / 08 / 2013)^{56}$.

Trazemos esse recorte pois ele é produção discursiva de um sujeito que passou pela experiência de usar os óculos que conectam a rede eletrônica e apontamos que nessa produção também comparecem alguns dos sentidos analisados nos recortes anteriores, os quais são produções discursivas de sujeitos que não passaram por essa experiência. Também traz outros sentidos. De estranhamento. Seguido de uma familiaridade que finda por naturalizar a relação antes estranha.

Destacamos, então, que, no início do recorte figuram os significantes "estranha" e "estranho" marcando tanto "a sensação de vestir o Google Glass pela primeira vez" quanto marcando a forma que o sujeito acredita que será a impressão de "quem olha de fora" dessa cena, o que nos faz rememorar os apontamentos de Bidaud (2014) sobre a relação primeira do olhar e ser olhado. Nesses sentidos de estranhamento comparecem um sujeito que olha por meio de um objeto tecnológico e que supõe alguém que o olhe de fora, o que podemos associar com a relação do sujeito com o outro/espelho (Lacan, 1998c) no qual inicialmente não se reconhece

\footnotetext{
${ }^{56}$ Recuperado em 15 de agosto de 2013, de http://blogs.estadao.com.br/link/nada-mais-escapa-aos-olhos-e-aslentes-com-o-google-glass/
} 
e posteriormente passa ao reconhecimento, à acomodação de uma imagem, no caso, uma imagem de um corpo que veste um objeto tecnológico, pela primeira vez. Tais sentidos de estranhamento atravessam o dizer de um modo de interação com o objeto no qual as mãos não são necessárias, como acompanhamos no recorte 1 da presente Entrada Discursiva.

Todavia, salientamos que, naquele recorte, precisar das mãos foi associado a "incômodos" e nesse, não precisar das mãos foi nomeado como estranho e, ainda, produzindo efeitos de "não saber o que fazer com o dispositivo". A estranheza também acompanha o dizer sobre a "cabeça estática" por "falta de costume" com a relação com o objeto. Podemos dizer, então, de um sujeito que se depara com a convocação de seu corpo a interfacear um objeto, um objeto vestível, que causa um desconforto inicial ao aderir ao corpo e ao requerer o movimento (sutil) de partes do corpo na relação. A percepção de partes do corpo, esse esquartejamento no discurso, de partes sendo invocadas, traz à tona a fragmentação do eu e a acomodação da imagem suposta total. Há então algo que pulsa da imagem do corpo fragmentado em direção a um ideal, um ideal de potência. Tal horizonte ainda se afirma ao se discursivizar que esse objeto tecnológico devolve ao homem a postura ereta, ele pode olhar ao horizonte, já que com os smartphones, como vimos com a Figura 19, o olho se volta para baixo para olhar a tela do objeto. Todavia o horizonte agora ofertado com os objetos tecnológicos de conexão a rede e eletrônica que prometem a realidade aumentada é um horizonte muito próximo, posto que as imagens pululam na retina, e o sujeito está intimado a cada vez menos olhar distâncias.

Apontando a polissemia do enunciado "A mudança de ponto de vista é surpreendente", que tomamos de modo a girá-lo, de modo a não só apontar que o sujeito diz da mudança de ponto de vista propiciado pelos óculos, mas sim a mudança de (seu) ponto de vista em relação ao estranho anteriormente mencionado, passamos a abordar os efeitos de familiaridade trazidos pelo sujeito "depois de alguns minutos": "era como se eu tivesse ao acessório há tempos". A partir dessa enunciação, podemos, então, dizer da acomodação de uma imagem de um corpo que veste o objeto, e que, posteriormente passa a descrever as possibilidades interativas do objeto, de modo a concluir que "Nada mais escapa aos olhos - e às lentes", reverberando os sentidos de tudo poder ver se os olhos se acoplarem às lentes. "Nada mais escapa" silencia o que já abordamos sobre o olho e o olhar (Lacan, 1998d), sobre o nem tudo ver ainda que um dispositivo seja acoplado ao olho e isso lhe oferte ilusoriamente a impressão de que "nada escapa".

A seguir, acompanhando o processo de produção desse discurso, sinalizamos que o sujeito se lança a descrever o objeto tecnológico e o modo de usá-lo apontando as partes do corpo requisitadas, os tipos de comandos, as possibilidades que o objeto oferta ao sujeito, "com 
poucos toques", "poucos comandos", sendo possível "acessar e-mails, mapas e páginas de busca, além de tirar fotos e gravar vídeos em alta resolução (720p) que podem ser compartilhados nas redes sociais". Ou seja, com pouco movimento de partes do corpo, é possível se movimentar intensamente na rede eletrônica, como temos apontado, nos sentidos que vigoram na relação sujeito, corpo e objetos tecnológicos de conexão à rede eletrônica.

Também como dissemos, os comandos não são quaisquer, um deles é "Ok, Glass", todavia o sujeito enlaçado a formação discursiva do mercado desapercebe-se do lugar de corpo (inter)face, naturalizando esse modo de dizer ao/fazer com o objeto, embora estranhe e assinale que "conversar com um par de óculos em público é uma situação, no mínimo, desconfortável”. Seguindo na lógica mercadológica dos discursos analisados, a tendência é a naturalização. Porém, abordemos a divisão do sujeito que, comparece no discurso ao mesmo tempo em que o assujeitamento lhe oferta sentidos pré-estabelecidos e o empurra a ser corpo (inter)face que doa sua face para o acoplamento e para as redes sociais. Resta apontar que não há um único modo de dizer do objeto tecnológico e do corpo inter(face), que sentidos são legitimados e determinam a predominância de corpos assujeitados com ares de liberdade, enquanto o próprio corpo é destituído da naturalidade dos movimentos.

\subsection{Entrada Discursiva 3: Sentidos de potencialização de partes do corpo na conexão com o objeto tecnológico de conexão à rede eletrônica}

Na Entrada Discursiva 2 acompanhamos o processo de produção de sentidos de invocação de partes do corpo para a conexão com o objeto tecnológico, mais especificamente de invocação do olho. Nesse momento, acompanharemos o processo de produção de sentidos de pontencialização do olho, na medida em que comparece como interface dos objetos tecnológicos de conexão à rede eletrônica que propiciam a realidade aumentada. Objetos que se miniaturizam e se acoplam a face e ao olho, que são discursivizados como potentes pela formação discursiva do mercado, e que, ao serem acoplados a partes do corpo, além de pontecializá-las, potencializam imaginariamente o corpo livre no virtual.

O sujeito ao se identificar com a formação discursiva do mercado produz sentidos para um corpo potente e livre, ao passo que é assujeitado ao modo de utilização do objeto tecnológico (Braunstein, 2010), assujeitado a ser interface, não se dando conta de que é invocado a portar o objeto tecnológico o tempo todo, capturado na injunção de estar online, consumindo cada vez 
mais rede eletrônica e cada vez mais objetos. Apontamos, assim, os deslimites para o gozo com o objeto tecnológico. Como vimos com Sternick (2010), Lacan assinala que o corpo pode ser deserto de gozo, ao que ela acrescenta, ao ser tomado no campo da máquina, pois um corpo deve ser subjetivado. O que temos escutado é um corpo silenciado, ao passo que é dito como ciborgue, e que é discursivizado como fragmentado e potente na relação com o objeto tecnológico. Tais discursos suportam um corpo deserto de gozo, que, para gozar precisa do objeto, pois não sabe gozar sem este. Tais discursos capturam o sujeito no engodo de suprir o desejo, a tentar encontrar o suposto objeto perdido, e entrar na repetição de nunca encontrá-lo, e de insistir em acreditar que existirá um objeto a completá-lo.

Também vimos com Sternick (2010) que um corpo deserto de gozo se fixa nos furos do corpo, onde pulsam os objetos parciais, e no caso dos objetos tecnológicos que estudamos, estes buscam o olho, nele também se fixando, se acoplando. Os sentidos que legitimam os objetos, ofertam, então, o silenciamento do furo com a possibilidade de supostamente tudo ver. Barram de outro modo os sentidos de que o olho e o olhar são castrados (Lacan, 1998d), afirmando a potência da visão, se o sujeito estiver na companhia do objeto, bem identificado a forma-sujeito do mercado e doando seu corpo como (inter)face. Sublinhamos, sobretudo que, a formação discursiva do mercado ao operar com os sentidos de potência, produz ainda sentidos de déficit ao corpo/olho que não porta o objeto tecnológico. Como já vimos, produz também um corpo cada vez mais inerte, que só movimenta os olhos, como numa paraplegia, porém um corpo constituído por discursos de potência ao órgão que tudo vê e tudo vive na realidade aumentada, na rede eletrônica. Um corpo potente no virtual, colado a imagem especular de um ideal.

\section{Recorte 1 \\ [...] quando amplamente utilizado pela humanidade, o Glass poderá se transformar em nossa "memória". \\ [...] humanos nunca foram bons em armazenar informações e transmiti-las para a posteridade e isso seria assumido pelos óculos do Google. [...] \\ [...] o que o Glass faria seria armazenar a experiência vivida por cada um de nós e digitalizá-la para que sejam retransmitidas para as futuras gerações. $(04 / 07 / 2014)^{57}$.}

Destacamos que no processo de produção de sentidos nesse recorte, o significante "memória" é tomado de diferentes modos quando referido à memória dos "humanos" e quando referido à memória do “dispositivo". Para tecermos nosso gesto de interpretação a esses modos

\footnotetext{
${ }^{57}$ Recuperado em 4 de julho de 2014, de http://canaltech.com.br/noticia/google-glass/Google-Glass-fara-proximarevolucao-cientifica-diz-inventor-dos-oculos/\#ixzz38uiIPuP3>
} 
de dizer sobre a memória, trazemos as contribuições de Orlandi (2007b) que nomeia a memória da máquina como "memória metálica", aquela da ordem do armazenamento, do acúmulo de informações inerentes aos objetos tecnológicos e nomeia como "memória histórica" aquela inerente aos sujeitos, capaz de política, metáforas, rupturas, associações, deslocamentos.

Salientamos, assim, que essas noções comparecem nos sentidos legitimados no presente recorte, de modo estereotipado, tomando-se a memória da máquina como só potente e a memória dos humanos como falhosa, na medida em que aponta que "humanos nunca foram bons em armazenar informações e transmiti-las" e que os óculos assumiriam essa função, de “armazenar”, digitalizar e retransmitir memória para futuras gerações, transformando-se, então, “em nossa 'memória' ”. Apontamos, assim, que há uma destituição da memória histórica em pról da legitimação da memória metálica e uma potencialização da memória humana ao se metalizar, supostamente tudo podendo armazenar, registrar, e mais, transmitir.

No processo de produção desses sentidos, naturaliza-se que é a memória do objeto que é potente, que tudo guarda, nada perdendo, podendo as imagens/informações/arquivos serem armazenados, reproduzidos quantas vezes se quiser, como destacam Orlandi (2007b, 2012a) e Romão (2012). Os sentidos legitimados sobre potência, advindos da formação discursiva do mercado e, por sua via, apoiada pela e apoiadora da ciência (posto que esta enunciação parte do físico que criou os óculos ${ }^{58}$ ), constituem discursos em que o furo, é considerado falha, déficit, defasagem.

Reverbera nesse recorte uma posição-sujeito que faz legitimar a potência da memória histórica ao ser transformada em memória metálica. Uma posição que na relação de interface com o objeto tecnológico aposta que a completude é possível e se esquece, no sentido pecheuxteano, que há falta no sujeito, no objeto e no discurso. Esquece que, ainda que o objeto tecnológico registre informações, não é tudo que ele é capaz de registrar, afinal é movido a bateria falível, há um olho que direciona aquilo que é visto por meio dos óculos, aquilo que é registrado, há ainda comandos que possibilitam que algo seja gravado de dado modo e não de outro. Há uma escuta do sujeito que seleciona o que será armazenado. Há ainda o fato de que a transmissão, a retransmissão não escapa à interpretação de cada sujeito que assiste, que grava. Assim, o armazenamento não é simplesmente feito por uma máquina que tudo capta a qualquer momento.

\footnotetext{
${ }^{58}$ Embora não consideremos o sujeito empírico é importante dizer que há um posicionamento em prol de sentidos que legitimam o poder do objeto tecnológico e de sentidos que alocam o corpo/memória histórica como falhosos e não como da ordem da falta.
} 
A máquina é regulada por sujeitos, que, embora assujeitados ao modo de emprego do objeto tecnológico, também dele faz uso, imprimindo sua marca faltante. Salientamos, por fim, que o sujeito do discurso não se dá conta de que o próprio Arquivo (Romão, 2013) não é acessível e acessável como um todo. Acredita que armazenar informações equivale a ter tudo sob controle, pelo efeito de legitimição ideológica do objeto. A própria criação de mais e mais equipamentos para se tentar garantir o salvamento de informações como HDs, as atuais nuvens, são passíveis a falha. De outro ângulo, trata-se de um tipo de memória que, como apontou Orlandi (2007b), não é capaz de política, é capaz de numerização e arquivamento, mas, sujeita à falha.

O episódio "The entire history of you”, do seriado "Black Mirror" (Armstrong \& Welsh, 2011), traz os sentidos evocados nesse recorte, apresentando personagens que utilizam um dispositivo implantado atrás da orelha e que possibilita gravar cenas cotidianas. Há um ideal de tudo armazenar e de poder rever as cenas armazenadas tentando controlar o que escapa ao controle, e o que ocorre é a perda de controle. Temos a apontar também com o referido seriado, além dos sentidos que brotam desse recorte, que já há um gesto de interpretação que incide naquilo que será armazenado. E isso aponta o que Pêcheux (1999) e Romão (2012) delineiam, respectivamente sobre o arquivo e o Arquivo. $\mathrm{O}$ arquivo está submetido àquele que arquiva $\mathrm{e}$ nem tudo pode ser arquivado, sendo isso da ordem do impossível. Ademais, nem tudo do Arquivo é disponível ao sujeito. Há nas malhas do digital, censores, por exemplo, na rede eletrônica que determinam o que permanece e o que não permanece online. Um desses fatores determinantes é a própria obsolescência do objeto tecnológico no qual aplicativos deixam de funcionar em função da memória metálica que se esvai.

No recorte que analisamos, o sujeito faz naturalizar sentidos de um corpo semanticamente normal, se operar como interface do objeto tecnológico, estando ilusoriamente a salvo de suas faltas. Assim como na notícia que trouxemos sobre o homem que utliza 700 sensores, abordada no capítulo 2. Apontamos que no atual contexto sócio-histórico, sob a formação discursiva do mercado, o "normal" é legitimado na modalidade de sujeito que se identifica a comparecer como interface do objeto, sendo olhado com estranhamento aqueles que se recusam a isso. Um corpo semanticamente normal tem sido discursivizado como ciborgue, aquele que é capaz de armazenamento de informações, de tudo poder, ilusoriamente ocupando o lugar daquele que tudo vê e supostamente tudo oferta ao olho do outro, ou ainda à memória do outro, enlaçado aos enunciados do Sujeito/Outro Mercado. 
Recorte 2

Esses projetores instalados diretamente na superfície dos olhos [...] permitirão que os usuários assistam seus vídeos de olhos fechados. $(17 / 01 / 2011)^{59}$.

Nesse recorte, as lentes que conectam a rede eletrônica são chamadas de "projetores instalados diretamente na superfície dos olhos", modo que assinalamos como uma descrição do acoplamento olho/objeto tecnológico indiciando uma proximidade, um colamento entre parte do corpo e o objeto. Ademais tais projetores são embebidos em sentidos de que "permitirão" aos usuários que "assistam seus vídeos de olhos fechados". Pontuamos que sem esses projetores, as imagens possíveis ao sujeito de olhos fechados são as oriundas dos sonhos. É esse o possível do corpo, "de olhos fechados", produzir imagens na forma de sonhos, um ato criador, bem delineado por Freud (1900/2013) em “A interpretação dos sonhos”, obra na qual os assinala como realização de desejo, como imagens e significantes que se ligam a memória, e algo dizem do sujeito, do inconsciente. Já nesse recorte, comparecem imagens aos "olhos fechados" que advém de vídeos, e que convocam o corpo/olhos a um deslimite, já que os olhos que se fecham para dormir, para sonhar, são permitidos pelas lentes a continuarem alertas, a ver imagens prontas, a uma desconexão cada vez maior com o sujeito do inconsciente. Como disse Sternick (2010), utilizando palavras de Lacan, o corpo é convocado ao deserto de gozo, quando imerso nas máquinas, e em nossas palavras, é convocado a gozar com o objeto tecnológico e não gozar de um corpo.

Figura nesse recorte, a posição-sujeito corpo (inter)face se acoplando a sentidos de potência aos olhos, posto que esses poderão ver, ainda que as pálpebras desçam. O olho é convocado ao gerúndio interminável, que mencionamos com Gallo e Romão (2011), como se tudo pudesse ser visto o tempo todo. Há um empuxo ao ver, à visão sem limites, sentidos já bem naturalizados a que a forma-sujeito do mercado faz vigorar ao se enlaçar aos já-ditos da visibilidade. Assim, o sujeito se posiciona de modo a reproduzir um "corpo-face", interface, um "corpo-olho", que, potencializado ao assistir algo, antes da ordem do impossível, é convocado a um suposto possível. Suposto porque como já dissemos com Lacan (1998d) o olho é castrado. E como apontam Gallo e Romão (2011), em contrapartida, o sono comparece e o cansaço, apresentando a impossibilidade de se estar online o tempo todo.

Salientamos, portanto, que a formação discursiva do mercado tem convocado o corpo/olho à interface até quando ele se fecha. Tal empuxo ao objeto tecnológico já pudemos

\footnotetext{
${ }^{59}$ Recuperado em 23 de março de 2013, de http://www.inovacaotecnologica.com.br/noticias/noticia.php?artigo=lentes-contato-inteligentes-projetaraoimagens-retina\&id=010150110117\#.U6iznfldVn4)
} 
ver reverberar de certo modo na Figura 2, "Minha vida", na seção 1.4, na qual comparecem sentidos de um corpo convocado a conexão com o objeto tecnológico, o tempo todo, num fluxo contínuo (Romão, 2007), até quando dorme/sonha, consumindo-o e sendo por ele consumido, como apontamos na referida seção.

\begin{abstract}
Recorte 3
[...] a tecnologia ainda deve tornar possível enxergar bem objetos muito próximos ou ler palavras em telas muito pequenas. Neste caso, as lentes poderão permitir um "zoom" das letras e gerar telas com um tamanho equivalente a uma televisão 240 polegadas vista a uma distância de mais de três metros [...] Ao projetar imagens ligeiramente diferentes para cada olho, ainda será possível gerar a ilusão de $3 \mathrm{D}$, Full $\mathrm{HD}$ e imagens totalmente panorâmicas. $(03 / 12 / 2012)^{60}$.
\end{abstract}

Destacamos que o recorte descreve as funções das lentes de contato que conectam a rede eletrônica e permitem a realidade aumentada, ao mesmo tempo em que apontam as possibilidades ao olho que a esse objeto se acopla. Assim, esse discurso faz reverberar uma posição-sujeito que, acredita que sob os efeitos do objeto tecnológico passa a "enxergar bem" em condições que isso não seria possível sem o objeto. Instala um jogo de forças no qual o corpo-olho comparece como interface e tem com isso, uma potencialização do ato de “enxergar”. É um sujeito permitido a "enxergar bem" na medida em que se identifica a formasujeito do mercado e acopla seu olho ao objeto. Portanto, é a formação discursiva do mercado que cria condições para que uma forma-sujeito do mercado se constitua e o sujeito que a ela se identifica não se identifica de qualquer modo, mas sim com seu corpo (Orlandi, 2012a), interfaceando o objeto. Dessa forma, sujeito, corpo e objeto estão assujeitados a formação discursiva do mercado. Há outros modos de se dizer do sujeito, do corpo, do objeto, como temos apontado. Assim, é a formação discursiva do mercado que permite que sejam discursivizados como potentes na medida em que se acoplam um ao outro, sustentando que o objeto seja consumido e o corpo também.

Nesse recorte, podemos pontuar que a descrição do que a lente permite intensifica o campo de visão de tal modo que não se abre espaço para se questionar se o olho tudo isso veria ou ainda a aplicabilidade disso ao sujeito-corpo consumidor. O olho na condição de interface, diante do impossível de tudo ver, de ver tudo, é exposto ao que se nomeia "enxergar bem” por meio de um "zoom" que pode "gerar telas com um tamanho equivalente a uma televisão 240

\footnotetext{
${ }^{60}$ Recuperado em 20 de maio de 2013, de http://tecnologia.uol.com.br/ultimasnoticias/redacao/2012/02/03/pesquisadores-querem-lancar-lentes-de-contato-com-recursos-tecnologicosespeciais-em-2014.jhtm
} 
polegadas vista a uma distância de mais de três metros". E há silêncio sobre essa aplicabilidade, sobre a influência desse excesso imagético ao campo visual. Campo visual que é convocado cada vez mais no âmbito de uma proximidade com a imagem, deixando-se de lado o horizonte enquanto amplitude. Ventila-se com efeitos de naturalização, a projeção de imagens diferentes para cada olho somada "a ilusão 3D, Full HD” e "imagens panorâmicas". Assim, o excesso e a potência são legitimados a ponto de não se questioná-los. E a falta inerente ao olho e ao olhar, bem apontados por Lacan (1998d) fica silenciada no discurso.

\section{Recorte 4}

Ter uma lente de contato que permita a você enxergar melhor do que qualquer olho humano parece coisa de um futuro distante? [...]. Não quer ter o incômodo de usar lentes de contato? Versões futuras poderão ser implantadas diretamente dentro do seu olho. $(03 / 12 / 2012)^{61}$.

Na esteira do recorte 2 da Entrada Discursiva 2, o qual trouxe sentidos referentes a incômodos em usar as mãos ao manejar smartphones e apresentar as tecnologias vestíveis como uma solução para esses incômodos, acompanhamos no presente recorte a evocação de um possível incômodo ao usar lentes de contato, ao que é ofertado a possibilidade de no futuro objetos tecnológicos serem implantados "dentro do olho". Assim, apontamos que o poder do Mercado (Payer, 2005) faz circular sentidos de que sempre haverá um objeto tecnológico cada vez menor, mais acoplado ao corpo/olho, sem causar incômodos, e ainda possibilitar "enxergar melhor do que qualquer olho humano".

Enlaçado aos enunciados do mercado, o sujeito ocupa uma posição no discurso que não estranha o adentramento cada vez mais naturalizado do objeto tecnológico no corpo, e tece sentidos de potência ao olho conectado ao objeto e, por sua via, impotência ao olho não conectado, ainda que este seja um olho que enxergue dentro dos chamados padrões de normalidade. Assistimos, então, que a incidência dos enunciados do mercado, têm produzido um corpo supostamente deficitário e ávido por objetos tecnológicos, nesse caso, que permite conexão à rede eletrônica e sobretudo a realidade aumentada, pois assim, pode "enxergar melhor". Na esteira do presente recorte, estão outros que também trabalham com a proliferação de discursos sobre um olho potente associado, no caso, às lentes de contato, podendo supostamente superar o impossível do/ao olho. Vejamos:

\footnotetext{
${ }^{61}$ Recuperado em 20 de maio de 2013, de http://tecnologia.uol.com.br/ultimasnoticias/redacao/2012/02/03/pesquisadores-querem-lancar-lentes-de-contato-com-recursos-tecnologicosespeciais-em-2014.jhtm
} 
[...] permitem uma visão que vai muito além da capacidade do olho humano. $(03 / 12 / 2012)^{62}$

[...] é possível enxergar objetos de perto e de longe em níveis que o olho humano não pode ver. $(09 / 01 / 2014)^{63}$

[...] algo que seria impossível no olho em condições normais [...] $(09 / 01 / 2014)^{64}$.

"Uma visão além”, “em níveis que o olho humano não pode ver", “algo que seria impossível no olho em condições normais", são enunciados diferentes, mas que fazem reverberar sentidos de um corpo que, ao ofertar seu olho como (inter)face ao contato com o objeto tecnológico, pode ver além, pode ver o que seria impossível. Contudo, é uma posição sujeita a cegueira de não ver o que é o impossível, e é capturado, como na anamorfose (Lacan, 1998d) a ver somente os sentidos que estão mais a vista. Como dissemos em diversas passagens, ao olho/olhar não é possível tudo captar, tudo ver, ele é passível de engano, de equívoco e também de interpretações muito singulares. Ao passo que insiste na potência e na garantia, também trazemos ecos da formação discursiva do mercado interpelando outro sujeito:

Lentes de contato inteligentes garantem "visão sobre-humana". $(09 / 01 / 2014)^{65}$.

Assim, apontamos o sujeito e sua necessidade de garantia, de controle, de potência, que vai a busca de um corpo semanticamente potente, de uma visão acima da visão humana, que, se já aprimorada por meio dos telescópicos, microscópios e dos próprios óculos e lentes que se voltam para a correção de defasagens naturais do olho, dessa vez se lança à possibilidade da realidade aumentada, da qual a aplicabilidade é silenciada em prol dos sentidos facilmente consumíveis: os que visam potência. Se por um lado, as referidas necessidades, delineadas por Pêcheux (2008) no campo da necessidade de aparência, de categorizações lógicas, encontra respaldo na língua, que suporta essas discursividades, apontamos que a língua também suporta a desestabilização dos sentidos. E é pela via da desestabilização dos sentidos que nos

\footnotetext{
${ }^{62}$ Recuperado em 20 de maio de 2013, de http://tecnologia.uol.com.br/ultimasnoticias/redacao/2012/02/03/pesquisadores-querem-lancar-lentes-de-contato-com-recursos-tecnologicosespeciais-em-2014.jhtm

63 Recuperado em 10 de janeiro de 2014, de http://jornalggn.com.br/noticia/lentes-de-contato-inteligentesgarantem-\%E2\%80\%9Cvisao-sobre-humana\%E2\%80\%9D

64 Recuperado em 10 de janeiro de 2014, de http://jornalggn.com.br/noticia/lentes-de-contato-inteligentesgarantem-\%E2\%80\%9Cvisao-sobre-humana\%E2\%80\%9D

65 Recuperado em 10 de janeiro de 2014, de http://jornalggn.com.br/noticia/lentes-de-contato-inteligentesgarantem-\%E2\%80\%9Cvisao-sobre-humana\%E2\%80\%9D
} 
propusemos a destecer sentidos sobre a visão humana, arraigados em sentidos sobre uma "visão sobre-humana".

\section{Recorte 5}

Scoble acredita que o Google Glass pode enfrentar dificuldades nos primeiros anos de vendas porque considera o produto avançado demais para a atual geração. [...] $(07 / 01 / 2014)^{66}$.

Pinçamos nessa formulação discursiva o apontamento de possíveis dificuldades de vendas dos óculos que conectam a rede eletrônica e tais dificuldades circulam em torno do produto ser avançado demais. É interessante pontuar como que o sujeito, sustentando a formação discursiva do mercado (não se trata de um sujeito empírico qualquer), faz vigorar sentidos de que se o objeto enfrentar dificuldades de vendas, esta decorre de um atraso na geração atual, marcado no "produto avançado demais". Como dissemos anteriormente, a formação discursiva do mercado faz vigorar sentidos aos quais oferta condições para a identificação do sujeito à forma-sujeito dominante e coloca a não identificação no plano de um déficit na geração atual, ou seja, no conjunto de sujeitos-consumidores que compõem o contexto sócio-histórico atual.

Figura nessa formulação uma posição-sujeito corpo (inter)face na qual o objeto tecnológico é inquestionável, já o corpo é atrasado em relação ao avanço e, o sujeito-corpoconsumidor, se se posicionar de modo a não adquirir o objeto, é em função de não acompanhar o ritmo tecnológico, no âmbito de uma falha e não de uma falta inerente a constituição de sujeito, corpos e inclusive objetos, ou ainda, resultado de um processo que não inclua esses objetos tecnológicos como necessários, ao contrário do que espera o Mercado. Como apontou Braunstein (2010), no discurso do mercado, o agente do discurso são os "servomecanismos" e seu efeito é enlaçar o sujeito em uma modalidade de discurso que faz vigorar a supremacia destes, acima de qualquer outro discurso. Nos "servomecanismos" incide o Mercado silenciando outras possibilidades discursivas, outras posições-sujeito, e ainda a desidentificação, a contraidentificação.

Feito esse percurso pelas três Entradas Discursivas, temos a dizer, como um efeito de fechamento, que movidas pelas questões sobre como os discursos sobre os objetos tecnológicos de conexão à rede eletrônica fazem do corpo uma peça acoplada, tornando-o silente, parado, mas movente na rede, sem limites para o gozo com o objeto, consideramos que demos um passo

\footnotetext{
${ }^{66}$ Recuperado em 07 de janeiro de 2014, de http://canaltech.com.br/noticia/google-glass/Google-Glassdeve-chegar-ao-mercado-em-2014-e-custar-menos-que-o-iPhone/\#ixzz38uOBa7RW>
} 
a mais com os gestos de interpretação às materialidades discursivas encontradas, pois nos deparamos com outros sentidos sobre o corpo que, se silenciado em sua constituição faltante, comparece nos discursos via invocação de suas partes para fazer interface com o objeto tecnológico e tais partes são embebidas de sentidos de potência, ao passo que também se constitui discursivamente um corpo potente no virtual.

Assim, criamos entradas discursivas para analisarmos o silenciamento do corpo e, quando de seu comparecimento no discurso, a fragmentação do corpo via invocação de suas partes para a conexão com o objeto e a potencialização dessas partes e do corpo virtual. Nas entradas discursivas pudemos trabalhar a intertextualidade com as materialidades analisadas ao longo dos capítulos e, com isso, trabalhamos a exterioridade que constitui os processos de produção de sentidos sobre a relação sujeito, corpo e objetos tecnológicos de conexão à rede eletrônica.

Para lermos a exterioridade, elaboramos o que chamamos de formação discursiva do mercado para dizer das forças ideológicas que incidem na produção de sentidos sobre a relação referida. Elaboramos a forma-sujeito do mercado, aquela que trabalha a identificação dos sujeitos à formação discursiva dominante, e a posição-sujeito corpo (inter)face resultante do processo identificatório, posição na qual o sujeito se posiciona no discurso de dado modo para dizer do corpo como interface do objeto, para dizer do corpo-face, com sentidos associados ao ciborgue, e com sentidos barrados/silenciados de um corpo sujeito a falta.

Consideramos que no processo de constituição de sentidos sobre a relação sujeito, corpo e objetos tecnológicos de conexão à rede eletrônica, a formação discursiva do mercado interpela os sujeitos de modo a reproduzir univocidade nos discursos, silenciando o estranhamento na relação de assujeitamento/subordinação ao poder do Mercado (Payer, 2005). Apontamos que há um encontro de injunções que capturam o sujeito no campo ideológico e no campo do recalque inconsciente. Pois se o sujeito é interpelado ideologicamente por sentidos de potência se funcionar como interface do objeto tecnológico, sem que se dê conta desse assujeitamento com ares de liberdade, é justamente nesse ponto que ele é fisgado em sua constituição, posto que como vimos com Freud (1930/2010) e Lacan (1995, 2005), o sujeito segue na busca de um objeto que supostamente o completaria, sem também se dar conta de que a falta é o que o move e não o objeto em si, e que não há potência, esta é apenas ilusória.

Tão ilusória que a formação discursiva trabalha com a potência, inflando a cada momento um objeto produzido pela ciência, e desinflando outro. Assim como tem operado ao inflar com potência partes do corpo, aquelas que fazem interface com o objeto, e trabalhar com a promessa de um corpo total no virtual. Preso nessas injunções, os sujeitos fazem reverberar 
sentidos sobre ciborgue, silenciando um corpo que pulsa, que se movimenta na busca. Silencia a busca com o objeto, e, para não amortecer, o sujeito busca outro objeto diante de seu vazio e da promessa mercadológica de encontrar outro, mais, potente.

Com a Análise do Discurso e a Psicanálise buscamos apontar o corpo para além do organismo, para além da máquina, pois se do ponto de vista orgânico o corpo é puro funcionamento, do ponto de vista dos que apregoam sobre o corpo-máquina ele também é puro funcionamento. Todavia, apontamos que os discursos sobre o corpo-máquina, além de comporem o imaginário humano, como vimos com Lemos (2010a) - ao citar os homúnculos de Parecelso, Galetéia, o Golem, o próprio ciborgue -, são produtos de discurso, e produtos que a ideologia do mercado legitimou. Trabalhamos com o corpo constituído por discurso e ainda o corpo pulsional, constituído por imagem, por linguagem, por gozo e desejo, sendo o objeto uma miragem. 


\section{PORQUE O CORPO NÃO É O "DOMINGO DO PENSAMENTO”}

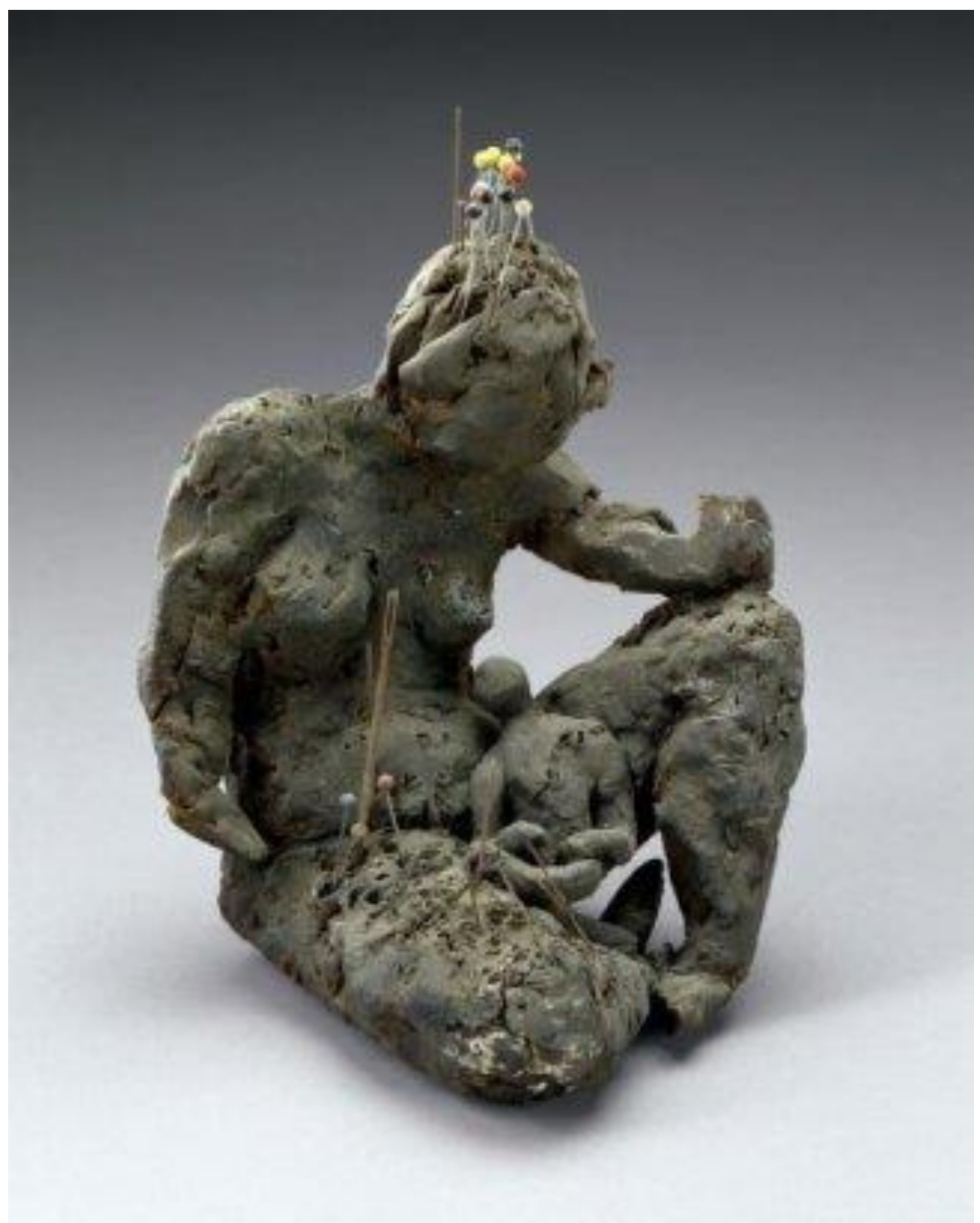

Mother and Child (Louise Bourgeois, 1970)

Palavras

[...] o mais interessante em tudo isto é descobrir que o discurso, em lugar de se limitar a iluminar e dar visibilidade ao que eu próprio julgava saber acerca do meu trabalho, acaba invariavelmente por revelar o oculto, o apenas intuído ou pressentido, e que de repente se torna numa evidência insofismável em que sou o primeiro a surpreender-me, como alguém que estava no escuro e acabou de abrir os olhos para uma súbita luz. Enfim, vou aprendendo com as palavras que digo. Eis uma boa conclusão, talvez a melhor, para este discurso. [...] (Saramago, 2009, p. 139) 
Como já citamos, Pêcheux (2008, p. 53), aponta que “[...] o humor e o traço poético não são o ‘domingo do pensamento' [...]”. Isso o fundador da Análise do Discurso diz em função da homogeneidade que impera(va) nas ciências (da linguagem), ao descartarem a desestabilização inerente à língua e ao alocarem essa desestabilização em um espaço linguageiro específico, excluído do trabalho com a língua. Não abrindo mão do poético e do humor, o fundador aponta o jogo de forças entre estabilização e desestabilização da língua, do sujeito, do discurso. Parafraseando-o, podemos dizer o mesmo do corpo, este que tem sido discursivizado como máquina, como ciborgue, como suporte da máquina convidado a seguir o modo de utilização, no processo de produção de sentidos sobre a relação com os objetos tecnológicos de conexão à rede eletrônica, embebido em potência, ou ainda, um corpo semanticamente normal (pautando-nos aqui no que o fundador da Análise do Discurso diz sobre um "mundo semanticamente normal"), que vela a desestabilização também própria ao corpo. Por isso, o corpo tal como o concebemos, "não é o domingo do pensamento", é corpo que pulsa no "cotidiano", tal qual "ato falho" (Freud, 1996h), inclusive fazendo barra ao estar online o tempo todo, como com o sono, os sonhos (Freud, 1900/2013), ainda que discursos insistam em afirmar um (corpo)-ciborgue sem limites na relação com o objeto tecnológico, convocando o olho a ver de olhos fechados, sem metáfora.

É para abordar esse corpo que faz barra, posto ser barrado, que trabalhamos com a posição-sujeito corpo (inter)face, uma posição-sujeito que, se se identifica com a formação discursiva dominante, do mercado, fazendo reverberar sentidos de potência e de ciborgue, traz em seus poros-vazão o silenciamento (Orlandi, 2007a) do corpo sobre o qual discursamos. Como apontamos ao longo da pesquisa, tal posição-sujeito foi depreendida do olhar e da escuta que lançamos às materialidades discursivas encontradas na rede eletrônica e a partir de todo o corpo teórico que tecemos no ir e vir do movimento pendular que instalamos em nosso dispositivo teórico-analítico (Petri, 2013), a partir das questões iniciais que nortearam nosso percurso na busca de compreender o processo de produção de sentidos sobre a relação sujeito, corpo e objetos tecnológicos de conexão à rede eletrônica neste início do século XXI.

Esse percurso foi possível ao nos apoiarmos na concepção de sujeito e de discurso de Pêcheux (2009a, 2009b, 2008, 2010), ambos atravessados pelo recalque do inconsciente e pela ideologia dominante que reverbera em cada contexto sócio-histórico, constituindo sujeitos que se identificam, se contra-identificam ou se desidentificam às formações discursivas dominantes, compondo posições plurais no discurso. Ademais, com Payer (2005) e Braunstein (2010), abordamos o poder do Mercado e o discurso do mercado legitimando sentidos para sujeito e corpo nesse tempo que habitamos. Apoiadas nesses autores, apontamos a identificação do 
sujeito/corpo com a formação discursiva do mercado e a forma-sujeito do mercado no processo de produção de sentidos sobre a relação sujeito, corpo e objetos tecnológicos de conexão à rede eletrônica. Sobre esses objetos específicos, pudemos defini-los a partir de teóricos da Análise do Discurso e da Psicanálise, trazendo outros sentidos sobre o objeto, para além dos sustentados pelo campo Informático e da Cibernética. Sentidos que trabalharam a busca inerente ao sujeito por um objeto perdido que supostamente o completaria (Freud, 1930/2010; Lacan, 1995, 2005) e seu enlaçamento aos enunciados do Mercado (Payer, 2005), que prometem ofertar objetos ditos cada vez mais potentes e mais acoplados ao corpo, às partes do corpo, fazendo-se imperceptíveis como no caso da lente de contato, e ainda os chips introjetados. Como abordamos o corpo e discursos que sobre ele incidem, buscamos estudar sentidos construídos historicamente, assim como trabalhamos com os conceitos de corpo na Psicanálise e na Análise do Discurso, na ordem da desestabilização do corpo, e também com o conceito de ciborgue presentificado na Cibercultura, o qual materializa a suposta estabilização, potencialização. Podemos dizer, então, que, articulando a historicidade, acompanhamos os discursos que incidem no corpo em cada contexto e também pudemos apontar a relação do sujeito com o corpo, composto por furos, por zonas erógenas, às quais correspondem os objetos parciais (oral, anal, fálico, invocador e escópico) que dão forma ao objeto $a$, este sim causa de desejo, objeto inexistente, mas que provoca o movimento desejante do sujeito, sujeito ao gozo, na busca pelo objeto. Temos acompanhado como a produção de objetos tecnológicos têm se dirigido aos olhos, órgão tomado por Lacan (2005) como objeto parcial, e como os discursos sustentados pelos enunciados do Mercado (Payer, 2005) ofertam a promessa de uma visibilidade ilusória, casada à visibilidade tão bem apontada por Debord (2003) ao dizer de uma sociedade do espetáculo.

Seguindo as pistas de um corpo fusionado, silenciado e ilimitado na relação com o objeto, ponto de onde partimos, encontramos os sentidos de invocação das partes eleitas para a conexão e potencialização destas, na medida em que o objeto tecnológico se miniaturiza a fim de se acoplar ao corpo. Retomando a posição-sujeito corpo (inter)face de modo a enfatizar o modo como o corpo e a face comparecem como interface do objeto, sendo invocados na relação com o objeto, apontamos os furos de um corpo nomeado ciborgue, misto de organismo e máquina (Haraway, 2009), e, como temos assinalado, o silenciamento (Orlandi, 2007a) do corpo faltante, fusionado ao objeto. Buscamos sinalizar o "inter"valo, nos poros das discursividades, o sujeito e o corpo na relação com o objeto enfatizando a não relação, como aponta Lacan (2003c), a não potência e a falta. Pela via do silenciamento, escutamos um corpo que pulsa e que se faz faltante ainda que os discursos sobre essa relação insistam em fazer "Um" 
(Lacan, 2003e) com o objeto, e insistam na possibilidade de se encontrar o objeto que complete sujeito e corpo.

Sobre a suposta completude do objeto, do sujeito e do corpo, temos a dizer, que há uma repetição de sentidos de potência a cada objeto lançado pelo mercado e aprimorado pela ciência. Tais sentidos que soam como um acontecimento, que, como dissemos anteriormente, não é discursivo posto que não há um deslocamento na posição-sujeito, mas somente um deslocamento no que tange às partes do corpo elencadas para comparecerem como interface, é movido a repetição e a regularização de sentidos. A atualização se refere apenas a um outro objeto tecnológico, conectado em uma dada parte do corpo, enquanto que os discursos são os mesmos, o que cristaliza uma forma de dizer do corpo e do sujeito que consome, nesse início de século. Portanto, são discursos que criam um "efeito" de completude pois na apresentação de um novo objeto, o anterior é despotencializado do mesmo modo que o sujeito e o (corpo)ciborgue.

Lembremos que as lentes de contato e os óculos que conectam a rede eletrônica e prometem a realidade aumentada ainda não são objetos colocados livremente ao consumo, mas, como dissemos, os anúncios os fazem proliferar no discurso antes de chegarem às vitrines, no jogo do Mercado. Um corpo que veste objeto tecnológico é o mote da formação discursiva do mercado, que, com um semblante de novo, faz circular o que já está posto de modo que, ainda que o sujeito em uma posição de questionamento ouse apontar que "paira uma certa sensação de incredulidade, em que mais uma vez a indústria tecnológica tenta nos vender algo de que não precisamos" ${ }^{\prime 67}$, como vimos, logo se desloca para a identificação apontando a necessidade do objeto. Nesse jogo de repetição e regularização, o sujeito é alçado na busca, na ordem da necessidade, como vimos no capítulo 2 , uma necessidade discursivizada como vital.

Cabe dizer que nosso posicionamento não é contra os objetos tecnológicos, nosso posicionamento como pesquisadoras é apontar como a formação discursiva do mercado tem contornado esses objetos no campo da potência, ofertando-os como aquilo que suprirá o sujeito, e por sua via constituem um corpo que é convocado a comparecer como interface e assim se oferta, um corpo cada vez mais inerte pois basta "um piscar de olhos" ${ }^{68}$ para se mover incessantemente na rede eletrônica, criando ares de um corpo fragmentado em olho, potente, e um corpo "todo" potente no virtual. Assinalamos ainda uma associação entre esse corpo

\footnotetext{
${ }^{67}$ Recuperado em 1 de abril de 2014, de http://blogs.estadao.com.br/homem-objeto/a-tecnologia-vestivel-podefazer-o-celular-virar-peca-de-museu/

${ }^{68}$ Recuperado em 23 de março de 2013, de http://www.tecmundo.com.br/ciencia/15995-fisico-renomado-revelacomo-sera-o-futuro.htm
} 
fragmentado e a imagem de um corpo total no virtual com o estádio do espelho em Lacan (1998c), que, constitutivo do eu, retorna na relação com o objeto na busca por um ideal de completude.

Cabe também lembrarmos que essa pesquisa foi constituída em uma íntima relação com o objeto tecnológico, a rede eletrônica, a rede social Facebook, letra a letra, num corpo a corpo, numa relação a olho com a tela do objeto tecnológico, numa relação de dedos moventes no teclado, numa relação de buscas, de encontros, de desencontros, na rede discursiva e não só eletrônica. Relação construída, escrita e inscrita na opacidade, que tece gestos de interpretação ao corpo, aos discursos sobre o corpo. A leitura que aqui se apresenta é possível a partir de um delineamento de um dispositivo teórico e metodológico, não sem análise. Sendo assim, dizemos que a relação sujeito, corpo e objetos tecnológicos de conexão à rede eletrônica pode se dar de outro modo. Como aponta Orlandi (2012d, p. 213), “[...] Nosso cuidado, ao criticar essas posições é indicar o movimento e a transformação, sem aceitar o voluntarismo e o automatismo mistificador". Automatismo que regula o processo de produção de sentidos sobre a relação sujeito, corpo e objetos tecnológicos de conexão à rede eletrônica, como se só houvesse um modo de dizer dessa relação, na via da potência. E ainda, na via da despotencialização do objeto e do corpo, de suas partes, tendo em vista um "novo" objeto, embebido em sentidos de mais potência, que potencializarão outras partes do corpo e o corpo suposto todo no virtual.

Apontamos que a relação do homem com objetos é apresentada por Freud (1930/2010) como um passo criador de instrumentos para o aprimoramento do corpo, produzindo a possibilidade de superar limites corpóreos. Não os cessar. Também apontamos que corpo e objeto ganham contornos discursivos diferentes a cada contexto sócio-histórico, porém, há uma relação que é repetitória em qualquer contexto sócio-histórico, que é a busca do sujeito por uma complementariedade na relação do corpo-objeto, do objeto-corpo (Freud, 1930/2010; Lacan, 1995, 2005). Uma necessidade de aparência (Pêcheux, 2008), de um corpo semanticamente normal, que paira nos diferentes contextos produzindo dadas condições para a criação de discursos, e destacamos que é característica dos discursos da pós-modernidade alocar os objetos tecnológicos de conexão à rede eletrônica como a resposta para os limites corpóreos, com a proposta da ilusão da cessação dos limites e não como um contorno de possibilidades que levam em conta o real do corpo. Na proposta de cessação dos limites está a concepção de ciborgue, um não corpo, um organismo maquínico.

Advertidas de que um "não corpo" é um modo de criar a ilusão de um corpo sem limites, que ganha nova nomeação, “ciborgue”, já que é supostamente outra coisa, insistimos em nosso gesto de interpretação em abordar o corpo silenciado e pulsante nos intervalos do discurso, 
posto que se há discursos que sustentam a potência e ainda uma supra-potência, investida em partes do corpo, como o olho, é porque há um movimento no discurso de negação da falta. Todavia, ela se dá a ver, na medida em que o olho continuará não capturando todas as informações que pululam em sua órbita pela via da interpelação ideológica, do recalque do inconsciente, da constituição via olho sempre faltante, e pela via do corpo fal(t)ante, que só cria objetos e discursos por assim ser constituído.

Assinalamos, pois, a relevância de um reviramento dos efeitos tidos como óbvios para a relação sujeito, corpo e objetos tecnológicos de conexão à rede eletrônica. Ou seja, efeitos de completude, de liberdade, de potência. Assim como a relevância de se opacizar a naturalização do acoplamento do objeto tecnológico no corpo, na pele que habitamos, no tempo que habitamos. Os discursos sobre a relação têm alocado o objeto tecnológico se servindo do corpo como órgão, e no que apontamos nessa pesquisa, pelo recorte que empreendemos nas materialidades discursivas encontradas, têm se dirigido ao olho/objeto da pulsão escópica de modo a silenciar o corpo como causa, furo, linguagem, metáfora, seu enlace ao real, imaginário, simbólico. São discursos que visam a preencher o corpo, ofertando dessa vez os óculos e as lentes que conectam a rede eletrônica e a realidade aumentada com um ideário de completude, fechando orifícios na promessa de abrí-los, de fazer ver mais, vendendo um corpo online, sem pausa. Isso porque a lente tampona o olho, assim como os óculos. Ambos objetos direcionam o que o sujeito vai ver na realidade aumentada, com as imagens da rede, prontas, e, por isso, dizemos que há um fechamento no campo visual, ainda que haja sobreposição da realidade com a realidade virtual. Ilusão de ver mais.

A Análise do Discurso e a Psicanálise restabelecem a noção de opacidade, de incompletude, de equívoco, de ambiguidade, de causa e deslocamento da fixação no objeto. Assim como a arte, a poética e o humor, também fazem circular outros sentidos para o corpo nos mobilizando a pensar a relação sujeito, corpo com objetos tecnológicos. Louise Bourgeois, artista plástica, nos apresenta seu trabalho com materiais metálicos, porosos, linhas, tecidos, em suas esculturas expondo o corpo à desestabilização de sentidos, à desestabilização da língua, e sobretudo, ao inconsciente, expondo também a estabilização, as celas. José Saramago, escritor, traz a movência da língua, o contorno ao corpo e o furo, os impasses com a porosidade, as paixões, as facetas. $\mathrm{Na}$ arte de Bourgeois, na arte de Saramago, pulsam a abertura de sentidos, o jogo entre estabilização e desestabilização, facetas não separadas, que compõem uma 
superfície que propicia giros, como a banda de Möebius ${ }^{69}$. Artista e escritor escolhidos, dentre tantos outros, para acompanhar nosso olhar e escuta ao corpo, assim como a dança contemporânea, que, como arte do corpo movente o convoca ao improviso, para além dos gestos que o amordaçam.

Como vimos com Freud (1930/2010), os objetos passam pela criação do homem, na relação com o corpo, de desejo e de gozo. Cabe questionar as produções sustentadas pela formação discursiva do mercado, e o processo de produção de discursos e sentidos sobre a relação que estudamos, afinal, como aponta Lacan (2007), a relação com o corpo não é uma relação simples. Ao que acrescentamos, não é uma relação que se reduza a potência. Ademais, não há relação, não há objeto que complete, há causa de desejo, $a$.

69

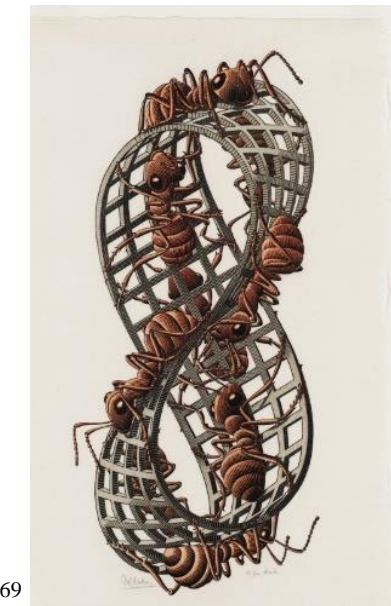

A banda de Möebius é uma figura topológica utilizada por Lacan (2005, p. 144) para apontar, dentre muitas questões, que o interior e o exterior, o direito e o avesso estão materializados em uma única figura, em sua torção, a partir da qual "[...] uma formiga que passeie em seu exterior passa sem nenhuma dificuldade para o interior". Ilustrada com obra de Escher (1968), denominada "Fita de Möebius II". (Recuperada em 16 de março de 2016, de http://www.maxernstmuseum.lvr.de/de/ausstellungen/vorschau/escher.html) 


\section{REFERÊNCIAS}

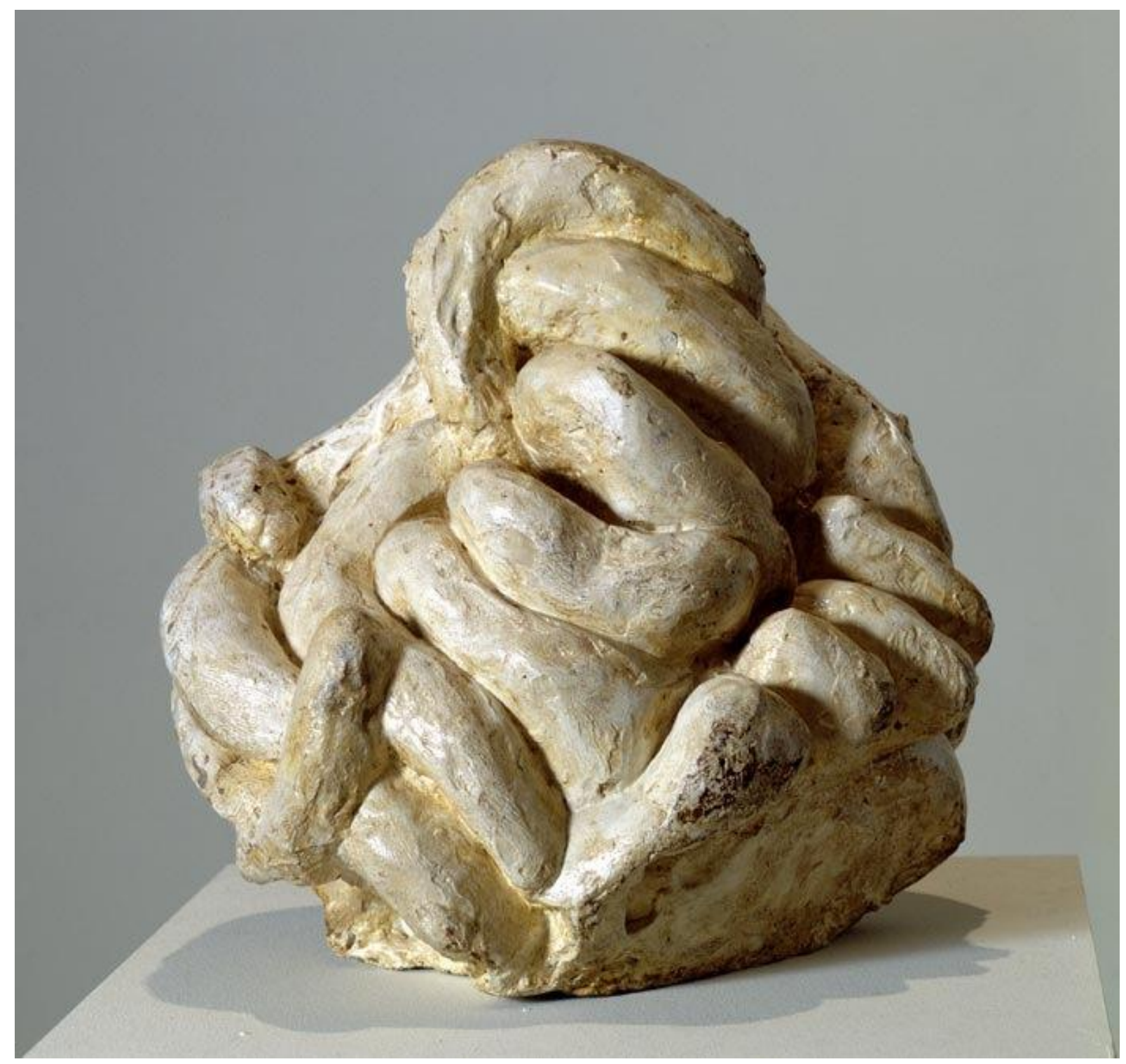

Clutching (Louise Bourgeois, 1962)

Biografias

[...] Seria indiscutível, por exemplo, que obras como os diários de Amiel, de Kakfa ou de Virgínia Woolf, a biografia de Samuel Johnson, a autobiografia de Cellini, as memórias de Casanova ou as confissões de Rousseau, a par de tantas outras de importância humana e literária semelhante, deveriam permanecer no planeta onde haviam sido escritas para que fossem testemunho da passagem por este mundo de homens e mulheres que, pelas boas ou más razões do que tinham vivido, deixaram um sinal, uma presença, uma influência que, tendo perdurado até hoje, continuarão a deixar marcadas as gerações vindouras.[...] (Saramago, 2009, p. 32) 
Agamben, Giorgio. (2009). O que é o contemporâneo? e outros ensaios. Chapecó: Argos.

Armstrong, Jesse \& Welsh, Brian (2011). The entire history of you (Black Mirror). UK: Zepprotron.

Authier-Revuz, Jacqueline. (2010). Falta do dizer, dizer da falta: as palavras do silêncio. In Eni Pulcinelli Orlandi, Gestos de leitura: da história no discurso (pp. 253-276). Campinas: Editora da Unicamp.

Azevedo, Aline Fernandes. (2013a). Cartografias do corpo: metáforas contemporâneas da sutura e da cicatriz. Tese (doutorado) - Universidade Estadual de Campinas, Instituto de Estudos da Linguagem. Campinas.

Azevedo, Aline Fernandes. (2013b). Tecnologias do corpo: metáforas da sutura e da cicatriz. RUA [online], 19(2), 95-107.

Baronas, Roberto Leiser (2007). Ainda sobre a noção-conceito de formação discursiva em Pêcheux e em Foucault. In Roberto Leiser Baronas (org). Análise de discurso: apontamentos para uma história da noção-conceito de formação discursiva. São Carlos: Pedro e João Editores, p. 169-184.

Bauman, Zygmunt. (1998). O mal estar da pós-modernidade. Rio de Janeiro: Zahar.

Bidaud, Éric. (2014). Vers une psychanalyse du visage. In. Éric Bidaud (org). Recherches de visages: une actualité de la psychanalyse. (pp. 15-29). Paris: Hermann Éditeurs.

Bidaud, Éric. (1998). Anorexia - mental, ascese, mística: uma abordagem psicanalítica. Rio de Janeiro: Companhia das Letras.

Braunstein, Nestor A. (2010/janeiro-junho). O discurso capitalista: quinto discurso? O discurso dos mercados (PST): sexto discurso? A peste, São Paulo, v. 2, n. 1, 143-165.

Castells, Manuel. (2003). A galáxia da Internet: reflexões sobre a Internet, os negócios e a sociedade. Rio de Janeiro: Jorge Zahar.

Cebrián, Juan Luis. (1999). A rede: como nossas vidas serão transformadas pelos novos meios de comunicação. São Paulo: Summus. 
Corbin, Alain, Courtine, Jean-Jacques, \& Vigarello, Georges. (2008). Prefácio. In Alain Corbain; Jean- Jacques Courtine; Georges Vigarello, História do corpo: da renascença às luzes (pp. 7-13). Petrópolis, RJ: Vozes. v. 1.

Corbin, Alain. (2008). Introdução. In Alain Corbain; Jean- Jacques Courtine; Georges Vigarello. História do corpo: da Revolução à Grande Guerra (pp. 7-10). Petrópolis, RJ: Vozes. v. 2.

Corrêa, Ivan (2011). A psicanálise e seus paradoxos: seminários clínicos. Recife: Centro de Estudos Freudianos do Recife.

Courtine, Jean-Jacques. (2008). Introdução. In Alain Corbain; Jean- Jacques Courtine; Georges Vigarello. História do corpo: as mutações do olhar (pp. 7-12). Petrópolis, RJ: Vozes. v. 3.

Courtine, Jean-Jacques. (1982). Definition d'Orientations Théoriques et Construction de Procédures em Analyse du Discours. Philosophiques, 9 (2).

Courtine, Jean-Jacques (1981). Quelques Problèmes Théoriques et Méthodologiques em Analyse du Discours, à propos du discours communiste adresse aux chrétiens. Langages, 15 (62), 9-128.

Cukiert, Michele, \& Priszkulnik, Léia. (2002). Considerações sobre eu e o corpo em Lacan. Estudos de Psicologia, 7(1), 143-149.

Debord, Guy. (2003). A sociedade do espetáculo. Recuperado em 25 de novembro de 2013, de http://www.ebookbrasil.com/eLibris/socespetaculo.html.

Dias, Cristiane (2012). Sujeito, sociedade e tecnologia: a discursividade da rede (de sentidos). São Paulo: Hucitec.

Dias, Cristiane. (2011). Corpo-sujeito-máquina-escritura. In Lucília Maria Sousa Romão; Fernanda Correa Silveira Galli. (Orgs). Rede eletrônica: sentidos e(m) movimento (pp. 23-35). São Carlos: Pedro \& João Editores.

Dias, Cristiane. (2008). Da corpografia: ensaio sobre a língualescrita na materialidade digital. Santa Maria: UFSM PPGL. 
Fingermann, Dominique. (2010julho/dezembro). Corpo e repetição: encore. A Peste, 2(2), 337-345.

Freud, Sigmund (1900/2013). A interpretação dos sonhos. L\&PM.

Freud, Sigmund. (1930/2010). O mal estar na civilização. In Sigmund Freud, O mal estar na civilização, novas conferências introdutórias à psicanálise e outros textos (pp. 13-122). São Paulo: Companhia das Letras.

Freud, Sigmund. (1920/1996a). Além do princípio do prazer. In Sigmund Freud, Obras completas de Sigmund Freud: edição standard brasileira (Vol.18, pp. 13-75). Rio de Janeiro: Imago.

Freud, Sigmund (1925/1996b). A negativa. In Sigmund Freud, Obras completas de Sigmund Freud: edição standard brasileira (Vol.19, pp. 263-269). Rio de Janeiro: Imago.

Freud, Sigmund (1908 [1907]/1996c). Escritores criativos e devaneio. In Sigmund Freud, Obras completas de Sigmund Freud: edição standard brasileira (Vol. 9, pp. 133-143). Rio de Janeiro: Imago.

Freud, Sigmund. (1919/1996d). O estranho. In Sigmund Freud, Obras completas de Sigmund Freud: edição standard brasileira (Vol. 17, pp. 235-273). Rio de Janeiro: Imago.

Freud, Sigmund. (1923/1996e). O eu e o id. In Sigmund Freud, Obras completas de Sigmund Freud: edição standard brasileira (Vol. 19, pp. 15-80). Rio de Janeiro: Imago.

Freud, Sigmund. (1895 [1950]/1996f). Projeto para uma psicologia científica. In Sigmund Freud, Obras completas de Sigmund Freud: edição standard brasileira (Vol.1, pp. 335-454). Rio de Janeiro: Imago

Freud, Sigmund (1915/1996g). Repressão. In Sigmund Freud, Obras completas de Sigmund Freud: edição standard brasileira (Vol.14, pp. 147-162). Rio de Janeiro: Imago.

Freud, Sigmund (1901, 1996h). Sobre a psicopatologia da vida cotidiana. In Sigmund Freud, Obras completas de Sigmund Freud: edição standard brasileira (Vol.6). Rio de Janeiro: Imago. 
Freud, Sigmund. (1914/1996i). Sobre o narcisismo: uma introdução. In Sigmund Freud, Obras completas de Sigmund Freud: edição standard brasileira (Vol.14, pp. 108). Rio de Janeiro: Imago

Freud, Sigmund. (1925 [1924]/1996j). Uma nota sobre o bloco mágico. In Sigmund Freud, Obras completas de Sigmund Freud: edição standard brasileira (Vol. 19, pp. 253-259). Rio de Janeiro: Imago.

Freud, Sigmund.(1917/19961). Uma dificuldade no caminho da psicanálise. In Sigmund Freud, Obras completas de Sigmund Freud: edição standard brasileira (Vol. 17, pp. 145152). Rio de Janeiro: Imago.

Foucault, Michel. (1991). Vigiar e Punir: o nascimento da prisão. 9. ed. Petrópolis: Vozes.

Gallo, Solange Leda, \& Romão, Lucília Maria Sousa. (2011). Corpo e(m) discurso na rede. In Lucília Maria Sousa Romão; Fernanda Correa Silveira Galli (Orgs), Rede eletrônica: sentidos e(m) movimento (pp. 13-22). São Carlos: Pedro \& João Editores.

Giorgenon, Daniela. (2011). Sentidos de inclusão e exclusão na voz de sujeitos escolares: o deslocamento do déficit pela via da falta. Dissertação de Mestrado, Faculdade de Filosofia, Ciências e Letras de Ribeirão Preto da Universidade de São Paulo, Ribeirão Preto.

Guyton, Arthur C. (1988). Fisiologia humana. Rio de Janeiro: Guanabara.

Ginszburg, Carl. (1989). Sinais: raízes de um paradigma indiciário. In Carl Giznburg, Mitos, emblemas e sinais (pp. 143-180). São Paulo: Companhia das Letras.

Glossário de Termos do Discurso: Projeto de pesquisa A aventura do texto na perspectiva da teoria do discurso: a posição do leitor-autor (2001). Orientadora Maria Cristina Leandro Ferreira. Bolsista de Inciação Científica Ana Boff de Godoy [et al]. Porto Alegre: UFRGS Instituto de Letras.

Haraway, Donna. (2009). Manifesto ciborgue: ciência, tecnologia e feminismo-socialista no final do século XX. In Donna Haraway, Hari Kunzru, Tomaz Tadeu (org.), Antropologia do ciborgue: as vertigens do pós-humano (pp. 33-118). Belo Horizonte: Autêntica Editora.

Kastrup, Virgínia (2010). A rede: uma figura emírica da ontologia do presente. In André Parente, Tramas da rede: novas dimensões filosóficas, estéticas e políticas da comunicação (pp. 17-38). Porto Alegre: Sulinas 
Kirner, Cláudio, \& Siscoutto, Robinson. (2007). Realidade virtual e aumentada: conceitos, projeto e aplicações. Livro do Pré-Simpósio IX Symposium on Virtual and Augmented Reality. Petrópolis, RJ, 28 de Maio de 2007.

Lacan, Jacques. (2008). O seminário, livro 7, a ética da psicanálise. Rio de Janeiro: Jorge Zahar.

Lacan, Jacques. (2007). O seminário, livro 23, O sinthoma. Rio de Janeiro: Jorge Zahar.

Lacan, Jacques. (2005). O seminário, livro 10, a angústia. Rio de Janeiro: Jorge Zahar.

Lacan, Jacques (2003a). Da psicanálise e suas relações com a realidade. In Jacques Lacan, Outros Escritos (pp. 350-358). Rio de Janeiro: Jorge Zahar.

Lacan, Jacques. (2003b). O aturdito. In Jacques Lacan, Outros Escritos (pp. 448-497). Rio de Janeiro: Jorge Zahar.

Lacan, Jacques. (2003c). Radiofonia. In Jacques Lacan, Outros Escritos (pp. 400-447). Rio de Janeiro: Jorge Zahar.

Lacan, Jacques. (2003d). Televisão. In Jacques Lacan, Outros Escritos (pp. 508-543). Rio de Janeiro: Jorge Zahar.

Lacan, Jacques. (2003e). ...ou pior. In Jacques Lacan, Outros escritos (pp. 554-549). Rio de Janeiro: Zahar.

Lacan, Jacques. (1998a). A coisa freudiana. In Jacques Lacan, Escritos (pp. 402-437). Rio de Janeiro: Jorge Zahar.

Lacan, Jacques. (1998b). A instância da letra no inconsciente ou a razão desde Freud. In Jacques Lacan, Escritos (pp. 496-535). Rio de Janeiro: Jorge Zahar.

Lacan, Jacques. (1998c). Função e campo da fala e da linguagem em psicanálise. In Jacques Lacan, Escritos (pp. 238-324). Rio de Janeiro: Jorge Zahar.

Lacan, Jacques. (1998c). O estádio do espelho como formador da função do eu. In Jacques Lacan, Escritos (pp. 96-103). Rio de Janeiro: Jorge Zahar. 
Lacan, Jacques. (1998d). O seminário, livro 11, os quatro conceitos fundamentais da psicanálise. Rio de Janeiro: Jorge Zahar.

Lacan, Jacques (1998e). O tempo lógico e a asserção da certeza antecipada. In Jacques Lacan, Escritos (pp. 197-213). Rio de Janeiro: Jorge Zahar.

Lacan, Jacques (1995). O seminário, livro 4, a relação de objeto. Rio de Janeiro: Jorge Zahar.

Lacan, Jacques. (1992). O seminário, livro 17, o avesso da psicanálise. Rio de Janeiro: Jorge Zahar.

Lacan, Jacques (1985). O seminário, livro 20, Mais, ainda. Rio de Janeiro: Jorge Zahar.

Lagazzi, Suzy. (1988). O desafio de dizer não. Campinas, SP: Pontes.

Leandro-Ferreira, Maria Cristina. (2013). O corpo enquanto objeto discursivo. In Verli Petri, Cristiane Dias (Orgs), AD em perspectiva: teoria, método e análise (pp. 141-152). Santa Maria: UFSM.

Leandro-Ferreira, Maria Cristina. (2012). Memória discursiva em funcionamento. In Lucília Maria Sousa Romão, Fernanda Silveira Correa Galli (Orgs), Conceitos discursivos em rede (pp. 141-152). São Carlos: Pedro \& João Editores.

Le Breton, David. (2003). Adeus ao corpo: antropologia e sociedade. Campinas: Papirus.

Lemos, André (2010a). Cibercultura: tecnologia e vida social na cultura contemporânea. Porto Alegre: Sulina.

Lemos, André. (2010b). Corpo e tecnologia. In André Lemos, Cibercultura: tecnologia e vida social na cultura contemporânea (pp. 161-184). Porto Alegre: Sulina.

Leonel, L. (2010, julho). O corpo encantado, In Entremeios, Univás: Pouso Alegre, n.1.

Lévy, Pierre. (2005). A infraestrutura técnica do virtual. In Pierre Lévy, Cibercultura (pp. 3144). 2. Ed. $5^{\text {a }}$ reimpressão. São Paulo: Ed. 34. 
Lévy, Pierre. (2004). As tecnologias da inteligência: o futuro do pensamento na era da informática. $13^{\mathrm{a}}$ reimpressão. Rio de Janeiro: Ed. 34.

Maldidier, Denise. (2010). Elementos para uma história da análise do discurso na França. In Eni Pulcinelli Orlandi, Gestos de leitura: da história no discurso (pp. 09-22). Campinas: Editora da Unicamp.

Marcuschi, Luiz Antônio. (1999). Linearização, cognição e referência: o desafio do hipertexto. In Luiz Antônio Marcuschi, Línguas e instrumentos linguísticos (pp. 21-46). Campinas: Pontes.

Mariani, Bethania. (2012). Análise do discurso e psicanálise. In Bethania Mariani, Vanise Medeiros (Orgs), Discurso e ... ideologia, inconsciente, memória, desejo, movimentos sociais, cinismo, corpo, witz, rede eletrônica, língua materna, poesia, cultura, mídia, educação, tempo, (homo)sexualidade (pp. 50-58). Rio de Janeiro: 7 Letras, FAPERJ.

Mariani, Bethania, Romão, Lucília Maria Sousa, \& Medeiros, Vanise (Orgs). (2012). Dois campos em (des)enlaces: discursos em Pêcheux e Lacan. Rio de Janeiro: 7 Letras.

Mauss, M. (1974). As técnicas corporais. São Paulo: EPU/EDUSP. v. 2.

Mittmann, Solange. (2007). Discurso e texto: na pista de uma metodologia de análise. In III Seminário de Estudos em Análise do Discurso, 2007. Anais do II SEAD - seminário de Estudos em Análise do Discurso, Porto Alegre: UFRGS. Recuperado em 19 de julho de 2015, de

http://www.ufrgs.br/analisedodiscurso/anaisdosead/2SEAD/SIMPOSIOS/SolangeMittmann.p df.

Musso, Pierre (2010). A filosofia da rede. In André Parente, Tramas da rede: novas dimensões filosóficas, estéticas e políticas da comunicação (pp. 17-38). Porto Alegre: Sulinas.

Orlandi, Eni Pulcinelli (2015). Era uma vez corpos e lendas. RiCOGNIZIONI: Rivista di lingue, letterature e culture moderne, 4, 209-219.

Orlandi, Eni Pulcinelli (2014a). Do não sentido e do sem sentido. Linguagem, 0, 3-17.

Orlandi, Eni Pulcinelli. (2014b/julho-dezembro). Parkour: corpo e espaço reescrevem o sujeito. Línguas e instrumentos linguísticos, 34, 75-87. 
Orlandi, Eni Pulcinelli. (2012a). Quando a falha fala: materialidade, sujeito, sentido. In Eni Pulcinelli Orlandi, Discurso em análise: sujeito, sentido, ideologia (pp. 69-82). Campinas, SP: Pontes Editores.

Orlandi, Eni Pulcinelli. (2012b). Processos de significação, corpo e sujeito. In Eni Pulcinelli Orlandi, Discurso em análise: sujeito, sentido, ideologia (pp. 83-96). Campinas, SP: Pontes Editores.

Orlandi, Eni Pulcinelli. (2012c). Corpo e sujeito: na dança, os sentidos. In Eni Pulcinelli Orlandi, Discurso em análise: sujeito, sentido, ideologia (pp. 97-105). Campinas: Pontes Editores.

Orlandi, Eni Pulcinelli. (2012d). Por uma teoria discursiva da resistência do sujeito. In Eni Pulcinelli Orlandi, Discurso em análise: sujeito, sentido, ideologia (pp. 213-234). Campinas: Pontes Editores.

Orlandi (2012e). Discurso e Leitura. 9. ed. São Paulo: Cortez.

Orlandi, Eni Pulcinelli (2010). Análise de Discurso: princípios e procedimentos. $9^{\mathrm{a}} \mathrm{ed}$. Campinas: Pontes Editores.

Orlandi, Eni Pulcinelli. (2008). Discurso e texto: formulação e circulação de sentidos. Campinas: Pontes.

Orlandi, Eni Pulcinelli. (2007a). As formas do silêncio: no movimento dos sentidos. Campinas: Editora da Unicamp.

Orlandi, Eni Pulcinelli. (2007b). Interpretação: autoria, leitura e efeitos do trabalho simbólico. Campinas: Pontes Editores.

Orlandi, Eni Pulcinelli. (2006, janeiro-dezembro). TEIAS, Rio de Janeiro, 13-14 (7), 1-7. Entrevista realizada por Raquel Goulart Barreto (UERJ).

Orlandi, Eni Pulcinelli. (2003). O objeto de ciência também merece que se lute por ele. In Denise Maldidier, A inquietação do discurso: (re)ler Michel Pêcheux hoje (pp. 9-13). Campinas: Pontes. 
Orlandi, Eni Pulcinelli (1996). Discurso: fato, dado, exterioridade. In M.P.F. Castro (org.), $O$ método e o dado no estudo da linguagem (pp. 209-218). Campinas: Unicamp.

Payer, Maria Onice. (2005). O. Linguagem e sociedade contemporânea - sujeito, mídia, mercado. Rua - Revista do Núcleo de Desenvolvimento da Criatividade da Unicamp - Nudecri, n. $11,09-25$.

Pêcheux, Michel. (2011a). Reflexões sobre a situação teórica das Ciências Sociais e, especialmente, da Psicologia Social. In Michel Pêcheux, Análise de Discurso: Michel Pêcheux, textos selecionados por Eni Orlandi (pp. 21-54). Campinas, SP: Pontes.

Pêcheux, Michel. (2011b). Nota sobre a questão da linguagem e do simbólico em Psicologia. In Michel Pêcheux, Análise de Discurso: Michel Pêcheux, textos selecionados por Eni Orlandi (pp. 55-72). Campinas, SP: Pontes.

Pêcheux, Michel. (2011c). As Ciências Humanas e o "Momento Atual”. In Michel Pêcheux, Análise de Discurso: Michel Pêcheux, textos selecionados por Eni Orlandi (pp. 175-202). Campinas, SP: Pontes.

Pêcheux, Michel. (2011d). Especificidade de uma disciplina de interpretação (A AD na França). In Michel Pêcheux, Análise de Discurso: Michel Pêcheux, textos selecionados por Eni Orlandi (pp. 227-230). Campinas, SP: Pontes.

Pêcheux, Michel. (2011e). Língua, linguagens, discurso. In Michel Pêcheux, Análise de Discurso: Michel Pêcheux, textos selecionados por Eni Orlandi (pp. 121-129). Campinas, SP: Pontes.

Pêcheux, Michel. (2011f). Análise do Discurso e Informática. In Michel Pêcheux, Análise de Discurso: Michel Pêcheux, textos selecionados por Eni Orlandi (pp. 275-282). Campinas, SP: Pontes.

Pêcheux, Michel (2011g). Metáfora e Interdiscurso. In Michel Pêcheux, Análise de Discurso: Michel Pêcheux, textos selecionados por Eni Orlandi (pp. 151-161). Campinas, SP: Pontes.

Pêcheux, Michel; Gadet, Françoise. (2010a). A língua inatingível. Campinas: Editora RG.

Pêcheux, Michel. (2010b). Análise Automática do Discurso (AAD-69). In Françoise Gadet, Tony Hak, Por uma Análise Automática do Discurso: uma introdução à obra de Michel Pêcheux (pp. 59-158). Campinas: Editora da UNICAMP. 
Pêcheux, Michel. (2009a). Semântica e Discurso: uma crítica à afirmação do óbvio. Campinas, SP: Editora da Unicamp.

Pêcheux, Michel. (2009b). Só há causa daquilo que falha ou o inverno político francês. In Michel Pêcheux, Semântica e Discurso: uma crítica à afirmação do óbvio (pp. 269-281). Campinas, SP: Editora da Unicamp.

Pêcheux, Michel. (2008). O discurso: estrutura ou acontecimento. Campinas: Pontes.

Pêcheux, Michel. (1999). O Papel da Memória. In: ACHARD, Pierre (et al.). Papel da memória. Campinas, SP: Pontes.

Pêcheux, Michel. (1997). Ler o arquivo hoje. In Eni Pulcinelli Orlandi, Gestos de leitura: da história no discurso (pp. ). Campinas, SP: Editora da UNICAMP.

Pêcheux, Michel, Haroche, Claudine, \& Henry, Paul. (2007). A semântica e o corte saussuriano: língua, linguagem, discurso. In Roberto Leiser Baronas, Análise do discurso: apontamentos para uma história da noção-conceito de formação discursiva (pp. 13-32). São Carlos: Pedro \& João Editores.

Petri, Verli. (2013). O funcionamento do movimento pendular próprio às análises discursivas na construção do "dispositivo experimental" da AD. In Verli Petri, Cristiane Dias (Orgs.), Análise do Discurso em perspectiva: teoria, método e análise (pp. 39-48). Santa Maria: Ed.da UFSM.

Petri, Verli. (2002). Por um acesso fecundo ao arquivo. Recuperado em 15 de janeiro de 2013, de http://corpus.ufsm.br/wp-content/uploads/2014/03/Por-um-acesso-fecundo-ao-arquivoword.pdf.

Plon, Michel. (2012). Lacan-Pêcheux, de um discurso outro, o impossível encontro. In Bethania Mariani, Lucília Maria Sousa Romão, Vanise Medeiros (Orgs.), Dois campos em (des)enlaces: discursos em Pêcheux e Lacan (pp. 15-29). Rio de Janeiro: 7 Letras.

Puech, Christian. (2005). L'émergence de la notion de "discours" en France et les destins du saussurisme. Langages, 39 (159), 93-110.

Quinet, Antônio. (2009). Com lalíngua no corpo. Stylus, revista de psicanálise. 19, 69-77. 
Robin, Regine. (2000). Du corps cyborg au stade de l'écran. Communications. 70, 183-207.

Romão, Lucília Maria Sousa. (2012). Fios de grito na rede: navega-dores (d)enunciam o extermínio. In Bethania Mariani, Vanise Medeiros (Orgs), Discurso e ... ideologia, inconsciente, memória, desejo, movimentos sociais, cinismo, corpo, witz, rede eletrônica, língua materna, poesia, cultura, mídia, educação, tempo, (homo)sexualidade (pp. 113-130). Rio de Janeiro: 7 Letras - FAPERJ.

Romão, Lucília Maria Sousa. (2007, janeiro-junho). O discurso sobre a mídia nos entremeios da narrativa de Saramago. Cadernos de Ciências Humanas - Especiaria. 17 (10), 215-245.

Romão, Lucília Maria Sousa. (2006). O cavalete, a tela e o branco: introdução à autoria na rede eletrônica. REVISTA DELTA, 2 (22), 303-328.

Romão, Lucília Maria Sousa. (2005). No país das maravilhas: uma metáfora sobre o dizer na rede. Revista Eletrônica de Divulgação Científica em Língua Portuguesa, Lingüística e Literatura, 3 (2), 1-12. Recuperado em 20 de março de 2011, de http://www.letramagna.com/lucilia_romao \%20.pdf.

Romão, Lucília Maria Sousa. (2004, julho-dezembro). Nós, desconhecidos, na grande rede. Linguagem em (Dis)curso - LemD, Tubarão, 1 (5), 71-91.

Saramago, José. (2009). O caderno: textos escritos para o blog setembro de 2008 - março de 2009. São Paulo: Companhia das Letras.

Schons, Carme Regina; Mittmann, Solange. (2009). A contradição e a (re)produção/transformação na e pela ideologia. In Freda Indursky e Maria Cristina LeandroFerreira, $O$ discurso na contemporaneidade: materialidades e fronteiras (pp. 295-304). São Paulo: Clara Luz.

Soler, Colette (2001). Lén-corps du sujet. Cours 2001-2002. Formation Clinique du Champ Lacanien. Inédito. Recuperado em 25 de maio de 2015, de xa.yimg.com/kq/groups/.../C.+Soler+L'+en-corps+de+sujet+aula+1.pdf.

Sousa, Lucília Maria Abrahão e, Garcia, Dantielli Assumpção, \& Faria, Daiana Oliveira. (2014, janeiro-junho). Paradigma indiciário, língua-concha, recorte e funcionamento: a metodologia em AD. Línguas e instrumentos linguísticos, 33, 93-108.

Sousa, Lucília Maria Abrahão e (2013). O vazio como condição: um movimento de sentidos a partir do horror. Gragoatá, Niterói, 34, 61-76. 
Sternick, Mara Viana de Castro. (2010, junho). A imagem do corpo em Lacan. Reverso, Belo Horizonte, (59), 31-38.

Vigarello, Georges. (2008). Introdução. In Alain Corbin, Jean-Jacques Courtine, Vigarello, Georges, História do corpo: da Renascença às Luzes. Petrópolis, RJ: Vozes. v. 1.

Zoppi-Fontana, Mônica (2013, dezembro). Análises del Discurso em Brasil: Teoría y Práctica. Signo y Seña, (24), 3-9. 